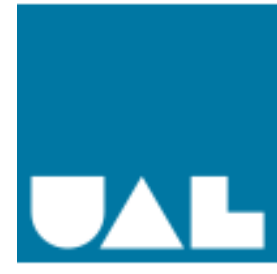

UNIVERSIDADE

AUTONOMA

DE LISBOA

\title{
As colecções de arte da Rainha D. Carlota Joaquina de Bourbon (1775- 1830): da colecção privada aos Museus Públicos. O manuscrito da Biblioteca da Ajuda: Memórias e Silêncios.
}

Investigação no âmbito do Doutoramento em História - D. Carlota Joaquina de Bourbon (17751830). Virtudes Privadas: o legado cultural - na Universidade Autónoma de Lisboa, sob a orientação do Professor Doutor Miguel Figueira de Faria.

Mafalda Magalhães de Barros

Barros, M. M (2019). As colecções de arte da Rainha D. Carlota Joaquina de Bourbon (17751830): da colecção privada aos Museus Públicos. O manuscrito da Biblioteca da Ajuda: Memórias e Silêncios. Lisboa: Universidade Autónoma. https://doi.org/10.26619/978-9899002-06-7

ISBN 978-989-9002-06-7

CDU 7

Como citar esta publicação:

APA

Barros, M. M. (2019). As colecções de arte da Rainha D. Carlota Joaquina de Bourbon (1775-1830): da colecção privada aos Museus Públicos. O manuscrito da Biblioteca da Ajuda: Memórias e Silêncios. Lisboa: Universidade Autónoma. https://doi.org/10.26619/978-989-9002-06-7

NP 405

Barros, Mafalda Magalhães de - As colecções de arte da Rainha D. Carlota Joaquina de Bourbon (1775-1830): da colecção privada aos Museus Públicos. O manuscrito da Biblioteca da Ajuda: Memórias e Silêncios [em linha]. Lisboa: Universidade Autónoma, 2019. Disponível em http://hdl.handle.net/11144/4459.

https://doi.org/10.26619/978-989-9002-06-7 


\begin{tabular}{|l|l|}
\hline Abreviaturas & 4 \\
\hline Introdução & 5 \\
\hline $\begin{array}{l}\text { I — Documentos inéditos da Biblioteca da Ajuda. Novos elementos. Novas } \\
\text { questões }\end{array}$ & 7 \\
\hline II — Das colecções privadas aos Museus Públicos & 12 \\
\hline $\begin{array}{l}\text { III - O Palácio-Quinta do Ramalhão. Arquitectura, poder e cultura. Diversos } \\
\text { testemunhos históricos. }\end{array}$ & 28 \\
\hline IV — A centralidade da arte na cultura de oitocentos. A “Caza da Pintura No 9" & 51 \\
\hline V - D. Carlota Joaquina e as Artes. & 63 \\
\hline VI - Do Brasil a Lisboa. Chegadas. O regresso a Casa & 74 \\
\hline VII - Incorporações. O manuscrito da Biblioteca da Ajuda & 83 \\
\hline $\begin{array}{l}\text { VIII - Trocas, dúvidas e interrogações. Teatros de Sombra e Luz. O Momento } \\
\text { Histórico }\end{array}$ & 105 \\
\hline $\begin{array}{l}\text { IX - O Momento Histórico. De Rainha consorte a Rainha-viúva. O novo papel de } \\
\text { D. Car-lota Joaquina na corte portuguesa. “A Santa Face”. De Roma a Lisboa? }\end{array}$ & 108 \\
\hline X — Partilhas, Dívidas e Leilões & 113 \\
\hline $\begin{array}{l}\text { XI - Reavaliação de um legado. As colecções de D. Carlota Joaquina de Bourbon. } \\
\text { Coleccionador, “connoisseur”, amador. }\end{array}$ & 117 \\
\hline XII - Conclusões e Notas Finais & 123 \\
\hline Bibliografia & 134 \\
\hline Anexos & \\
\hline
\end{tabular}




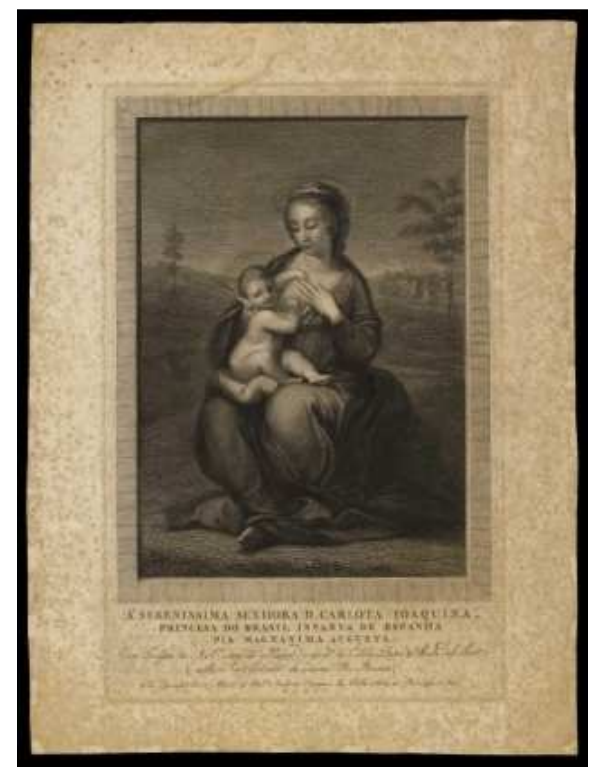

Nossa Senhora e o Menino, de João Caetano Rivara. Legenda com dedicatória - "À Sereníssima Senhora D. Carlota Joaquina, Princesa do Brasil, Infanta de Espanha, Pia Magnanime Augusta, Esta Imagem de N. Sr. $\underline{a}$ extrahida do Painel original do Celebre Pintor André del Sarto existente no Gabinete da mesma R. Princesa, João Caetano Rivara, Alumno da Real Academia Portuguesa das Bellas Artes em Roma. DOC" ${ }^{1}$, que nos informa ter o desenho sido feito a partir de uma pintura existente na colecção da então Princesa do Brasil.

1 Fundação da Biblioteca Nio Nanal, de Janeiro.

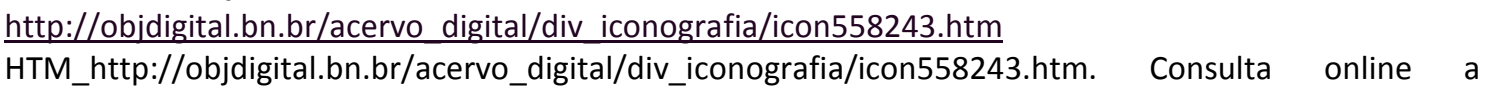
16.10.2019; SOARES, Ernesto, in História da Gravura Artística em Portugal. Os artistas e as suas obras, Tomo I, Lisboa, 1940, n.o 1703, p. 518. Este autor confirma apenas ter conhecimento desta gravura na colecção da Biblioteca Nacional do Rio de Janeiro. 


\section{Abreviaturas}

AHMF - Arquivo Histórico do Ministério das Finanças

ANBA - Academia Nacional de Belas Artes

ANTT- Arquivo Nacional da Torre do Tombo

BA - Biblioteca da Ajuda

MNAA - Museu Nacional de Arte Antiga

PNA - Palácio Nacional da Ajuda

POB - Colecção Pedro Orleans Bragança do Museu Imperial do Rio de Janeiro 


\section{I - Introdução}

Refere Francis Haskell que, na genealogia dos comportamentos de distinção, a preferência pelas colecções de pintura vem, a partir do século XVII, substituir os símbolos de opulência mais óbvios, utilizados anteriormente para demonstrar a riqueza e a nobreza dos seus proprietários ${ }^{2}$, o que constitui um facto muito significativo na história social da arte. Isto é, quando aos signos de riqueza e ostentação sucedem outros capazes de afirmar a superioridade, ou grau de instrução e cultura, do seu detentor.

Com o nosso trabalho pretendemos demonstrar que a colecção que possuía a Rainha D. Carlota Joaquina de Bourbon (1775-1830) são o reflexo da sua personalidade, culta e instruída, que o desejo de arte foi constante no seu quotidiano, o kunstwollen de que falava Alois Riegl (1858-1905). Talvez que este fosse determinado pela sua "natureza poética"3 a que se refere o historiador brasileiro, insuspeito de simpatias pela soberana, Manuel Oliveira Lima, quando na sua biografia sobre o seu marido, o Rei D. João VI (1767-1826) ${ }^{4}$, descreve o temperamento de D. Carlota Joaquina. Era esta predisposição, aliada a uma instrução precoce que a fazia rodearse de livros, conforme comprova a sua livraria, cujo catálogo se encontra na Biblioteca da Ajuda $^{5}$, de objectos de arte, testemunhados nos inventários post mortem, ou ainda de objectos artísticos que persistem nos Arquivos e nas colecções museológicas nacionais. Se politicamente representava os valores de Ancien Regime, foi, no entanto, uma personagem com traços de modernidade no que ao papel da mulher na vida pública respeita. $O$ desdém a que a votou uma historiografia de pendor liberal não apagou os aspectos relacionados com o seu legado cultural, de que as colecções públicas de arte dão testemunho. Será a esse campo de trabalho que dedicamos o nosso estudo.

Apesar de se tratar de um caso singular vem, no entanto, contribuir para a compreensão da importância dos legados materiais, consubstanciados nos espólios provindos do Antigo Regime, para a formação das instituições museológicas e culturais oitocentistas. Como escrevia Tocqueville "Des liens invisibles mais presque tout-puissants attachent les idées d'un siécle à celles du siècle qui l'a précédé, les goûts des fils aux penchants des pères. Une génération a beau déclarer la guerre aux générations qui I'on précédé, il est plus facile de les

\footnotetext{
${ }^{2}$ HASKELL, Francis, El museo efímero, Editorial Crítica, Barcelona, 2002, p. 25.

${ }^{3}$ LIMA, Oliveira, D. João VI 1808-1821, Ed. ACD Editores, 200 Anos Portugal Brasil, s/data, p. 184.

${ }^{4}$ LIMA, Oliveira, D. João VI 1808-1821, Ed. ACD Editores, 200 Anos Portugal Brasil, s/data.

${ }^{5}$ Catálogo da Livraria que foi de S. Mag.de A Senhora D. Carlota Joaquina de Bourbon, BA 51-XIII-7.
} 
combattre, que de ne leur point ressembler. On ne saurait donc parler d'une nation à une époque donnée, sans dire ce qu'elle a été un demi-siècle auparavant" ${ }^{\prime \prime}$.

O facto de a Princesa, depois Rainha e Imperatriz, ter vivido, em diversas etapas da sua vida, em separação de seu marido, tendo casa própria, permitiu-lhe ampliar, diversificar e, por fim, diferenciar os bens que constituíram o seu testamento, distinguindo-o daquele que era património da Coroa o que, não sendo muito comum, nos permite agora estudar de que maneira o seu legado pode ser testemunho dos gostos artísticos e da personalidade da sua possuidora, e de que modo o mesmo contribuiu para o enriquecimento das actuais colecções patrimoniais e museológicas nacionais, já que, contrariamente ao que escreve Alberto Pimentel (1849-1925), que "o theatro de S. Carlos [...]" seria "uma das poucas coisas estimáveis a que se liga o nome d'esta princeza"7 ${ }^{\prime 7}$ consideramos que a sua actuação no campo da cultura, e do patronato cultural, bem como do coleccionismo artístico, deixaram um legado, do qual as actuais colecções públicas nacionais são tributárias.

À luz do que fica dito importa, pois, reavaliar a actuação da última soberana do regime absoluto, pois podemos afirmar como Ceballos em relação ao reinado de seu pai Carlos IV (1748-1819) - "Dentro del campo de la cultura tampoco se ha tomado demasiado en consideración, hasta hace poco tiempo, lo que aportó este monarca a la protección de las artes y los artistas" ${ }^{\prime \prime}$

\footnotetext{
${ }^{6}$ TOCQUEVILLE, Alexis, L'Ancien Régime et la Revolution, GF Flammarion, Paris, 1988, p. 46.

7 PIMENTEL, Alberto, A última Côrte do Absolutismo em Portugal, Lisboa, Livraria Ferin, 1893, p. 26.

${ }^{8}$ CEBALLOS, Alfonso Rodriguez G. de, "Goya y Carlo IV", in Carlos IV y el Arte de su reinado, Actas de Jornadas de Arte e Iconografia, Fundación Universitaria Española, Madrid, 2011, p. 21.
} 


\section{Objectivos}

\section{I - Documentos inéditos da Biblioteca da Ajuda. Novos elementos. Novas questões}

No campo da História da Arte e do Coleccionismo, as colecções de pintura de D. Carlota Joaquina de Bourbon, Imperatriz do Brasil, Rainha de Portugal e dos Algarves, têm sido objecto de um crescente interesse, tanto por parte de museólogos e investigadores portugueses, como por parte do meio académico e museológico espanhol. Novos dados têm sido revelados, baseados em documentação de Arquivos portugueses e espanhóis, sugerindo propostas de interpretação alternativas, que suscitam novas interrogações.

O texto que apresentamos, a partir de um documento, até agora inédito, existente no acervo da Biblioteca da Ajuda, o manuscrito "Tercera Division, Cuadros adjudicados a la Serenissima Señora Infanta de España Dona Carlota Joaquina de Borbon, Reyna Viuda de Portugal, por la Testamanaria de los Señores Reyes Padres, en el año de $1826^{\prime \prime}{ }^{\prime}$, que enumera as pinturas que integraram a herança paterna de D. Carlota Joaquina, pretende contribuir para o melhor conhecimento das actuais colecções públicas de arte, e das coleç̧ões privadas que para elas contribuíram.

A partir da documentação relativa às partilhas dos reis Carlos IV de Bourbon (1748-1819) e Maria Luísa de Parma (1751-1819) que se encontra nos arquivos de Espanha, e da qual agora se confirmou a existência de um exemplar na Biblioteca da Ajuda - "Tercera Division [...]"10, correspondente à quota hereditária de D. Carlota Joaquina, sabemos que uma parte importante da colecção de pintura da soberana portuguesa era constituída por obras de arte que herdara de seus pais, ambos mortos no exílio italiano, em Janeiro de 1819. Aquele legado, como se depreende do manuscrito da Biblioteca da Ajuda ${ }^{11}$, não chegaria a Portugal antes de 1826, vindo juntar-se ao património de que a soberana já dispunha. Após a morte de D.

\footnotetext{
${ }^{9}$ Biblioteca da Ajuda ms. 54-X-33(7).

${ }^{10}$ CHECA, Carmen García-Frías, "Nuevas aportaciones al estúdio de la colección pictórica de Carlos IV en el exilio", in Actas de las Jornadas de Arte e Iconografia Carlos IV y el arte de su reinado, Fundación Universitaria Española, Outubro 2011, pp. 211 e 261. A autora refere os lotes da herança que couberam aos irmãos da soberana portuguesa, fazendo ainda algumas referências às pinturas do quinhão hereditário de D. Carlota Joaquina. A lista da Biblioteca da Ajuda - ms. 54-X-33 (7) -, contém os títulos das obras e autorias mas não inclui a dimensão das mesmas, nem nenhuma informação técnica, o que dificulta o trabalho de localização das pinturas. Tendo sido solicitada cópia daquele manuscrito aos Arquivos de Espanha, em Abril de 2016, não foi ainda possível obter cópia do mesmo, pelo que trabalhamos com base no exemplar da Biblioteca da Ajuda.

${ }^{11}$ BA ms. 54-X-33 (7).
} 
Carlota Joaquina, em 7 de Janeiro de 1830, parte das obras de arte que compunham a herança paterna e integravam o espólio do Palácio do Ramalhão, seria leiloada no Palácio da Bemposta, a partir de Dezembro de 1847. Mas não a totalidade, é o que defendemos. É, assim, nosso propósito, estabelecer conexões entre as pinturas inscritas no lote hereditário da ImperatrizRainha, correspondentes ao citado manuscrito, e, em simultâneo, propor uma reflexão sobre o possível impacto daquele conjunto no acervo do Palácio Nacional da Ajuda.

Partimos das seguintes questões para as quais tentaremos encontrar resposta:

- Teriam todas as obras provenientes do legado dos Reis Carlos IV e Maria Luísa de Parma, referentes à quota hereditária de D. Carlota Joaquina, que integram o manuscrito da Biblioteca da Ajuda 54-X-33 (7), sido recebidas e guardadas no Palácio do Ramalhão, nos anos 18261828 ?

- Habitando a então Imperatriz-Rainha outros espaços, nomeadamente os Palácios Reais de Queluz e da Ajuda teria, naqueles anos de 1826-1828, mandado arrecadar todo o espólio proveniente de Espanha na sua Casa de Sintra, ou teria feito deslocar algumas daquelas obras, para outros espaços residenciais?

- Do património herdado dos reis Carlos IV e Maria Luísa de Parma, inscrito na mencionada "Tercera Division", teriam todas as obras correspondentes à quota-parte da Imperatriz-Rainha, sido leiloadas na Bemposta, ou algumas não o foram, por não se encontrarem no Palácio do Ramalhão à data da morte da soberana? Ou à data da realização do inventário para efeitos do leilão que haveria de ocorrer no Palácio da Bemposta?

- A possibilidade de parte da colecção de pintura de D. Carlota Joaquina, leiloada na Bemposta, corresponder a herança paterna, que recebe poucos anos antes de morrer em 1830, permite-nos questionar o facto de D. Carlota Joaquina ter sido uma coleccionadora no sentido do "connoisseur", enquanto alguém que reúne, mediante um plano estruturado, um conjunto de obras de arte? Ou, pelo conjunto de referências documentais reunidas, algumas inéditas, podemos referir serem as suas colecções fruto de uma curiosidade intelectual e de uma predisposição para a arte, resultado de uma formação e de um convívio com obras de arte e artistas, que demonstram um perfil mais consentâneo com o de "amador" ${ }^{12}$, cujo gosto e curiosidade a levava a acumular obras de arte, de proveniências várias?

Fontes. É nosso propósito demonstrar que D. Carlota Joaquina era uma personalidade instruída e culta, que apoiou artistas, pintores, gravadores, escritores, desempenhando um

\footnotetext{
${ }^{12}$ V. Smentek, Kristel, Mariette and the Science of the Connoisseur in Eighteenth-Century Europe, Studies in Art Historiography, Ashgate, 2014, p. 3, para a definição destes termos.
} 
papel activo no campo cultural, na corte portuguesa. Para o efeito apoiar-nos-emos em documentação inédita, existente nos Arquivos Nacionais da Torre do Tombo e na Biblioteca da Ajuda, em alguma documentação do Arquivo Histórico do Museu Imperial de Petrópolis, Brasil $^{13}$, em publicações e periódicos oitocentistas e novecentistas portugueses que abordaram esta temática e em textos recentes no âmbito dos estudos sobre coleccionismo e museologia, elaborados por investigadores, académicos e museólogos, portugueses e espanhóis.

\section{A complexidade inerente ao estudo das colecções de Arte, no período de Antigo Regime, em}

\section{Portugal. Problemas da Investigação.}

O estudo das colecções de arte de Antigo Regime comporta dificuldades inerentes a este campo específico de trabalho, sendo a mais relevante a que se relaciona com a dispersão dos conjuntos, por força de vicissitudes várias, o que impossibilita a validação objectiva dos dados documentais. Talvez por essas razões, investigadores que se têm consagrado a esta temática, tais como Ângela Delaforce ${ }^{14}$ que dedica um importante estudo à arte e seus patronos no século XVIII em Portugal, ignoram o papel de D. João VI (1767-1826) ou de D. Carlota Joaquina (1775-1830) naquele domínio, excepto no que respeita as alusões ao gosto pela música, tão reconhecidamente característico dos Braganças. Como nos diz Paulo Varela Gomes (19522016), na recensão àquela obra, referindo-se à falta de ilustrações da mesma - "Its real cause is the fact that many works either no longer exist or their whereabouts are unknown, which also explains why Portugal's art collections and patrons have not attracted more international attention", levantando, em consequência, a importante questão - "What happened to most of the objects acquired by the Portuguese court and nobility from the sixteenth to the eighteenth century?"15. Infelizmente essa é uma das questões para a qual nem a autora, nem o crítico, fornecem respostas.

À complexidade inerente aos estudos em torno dos temas do mecenato cultural, ou do coleccionismo em Portugal, pois tem, como afirmamos, o historiador que se confrontar com a

\footnotetext{
13 Apesar das dificuldades por que passam as instituições museológicas tanto em Portugal como no Brasil e a falta de meios com que se debatem, o apoio da Dr.a Valeria Gauz e dos técnicos do Arquivo do Museu Imperial de Petrópolis, foi inexcedível na resposta aos pedidos de digitalização de documentação que íamos formulando.

${ }^{14}$ DELAFORCE, Angela, Art and Patronage in Eighteenth-Century Portugal, Cambridge University Press, 2002. A autora foca essencialmente o seu trabalho no reinado de D. João $V$ (1707-1750) e nas sumptuosas encomendas que o monarca faz, quer em Roma, quer em França, quer nos Países Baixos, medeadas por uma plêiade de embaixadores "iluminados", sendo, por isso, escassa a informação sobre os reinados posteriores.

15 GOMES, Paulo Varela, Reviewed Work(s): "Art and Patronage in the Eighteenth-Century Portugal by Angela Delaforce", in The Journal of the Society of Architectural Historians, vol. 62, n. 1, Mar. 2003, pp. 159-161.
} 
dispersão dos conjuntos e dos bens culturais, acresce "a dificuldade de determinar, na maioria dos casos, uma segura concordância entre os documentos escritos - especialmente no caso dos nomes de artistas atestados nos actos - e os quadros existentes" ${ }^{16}$, contestação pertinente efectuada por um autor em meados do século XX.

Inventários para efeitos de partilhas, com longas séries de objectos, pinturas sumariamente identificadas, e apressadamente medidas, constituem documentos e meios de trabalho, por vezes, pouco precisos. A esta dificuldade, juntamos a da reconstrução de um determinado momento histórico, quando a personagem central da investigação é uma figura feminina, e o âmbito do trabalho se relaciona, essencialmente, com a esfera da vida privada.

O silêncio da História, no que à dimensão da vida privada respeita, nomeadamente na que envolve a vida das mulheres neste período histórico, pois nem todos os seus actos são feitos em nome próprio, torna difícil estabelecer, com segurança, os agentes que se encontram por detrás das decisões. Como diz R. Bello Vásquez, o poder feminino era "um poder na sombra com grandes possibilidades de actuação" é certo, "tanto no campo intelectual como no campo do poder", desde que fosse invisível, daqui resultando que "as informações obtidas a partir da documentação coeva em muitos casos contrasta(re)m com a posterior recriação feita pela historiografia, que apaga o papel desenvolvido por mulheres e mediadoras ou mediadores, $o$ que evidencia a existência de processos pelos quais são construídas diferentes imagens [...] do rei e da rainha ou dos homens e mulheres da nobreza e dos seus diferentes papéis no campo do poder"17. $^{\prime 17}$.

O facto de a corte portuguesa ter vivido, a partir de 1807, aqueles tempos turbulentos da Guerra Peninsular (1808-1814), entre os dois lados do Atlântico, originou uma dispersão de documentos, de obras de arte e testemunhos, dificultando o acesso à investigação.

O facto de a leitura histórica sobre aquele período, se encontrar muito polarizada, sendo as imagens dominantes herdadas de uma historiografia que reflecte, essencialmente, o ponto de vista dos liberais ganhadores, que deformaram e caricaturaram, quanto puderam, as imagens dos soberanos e da corte do final de Antigo Regime, aconselha a que, como escreve Angela Delaforce, a história do coleccionismo seja feita com base em levantamentos documentais

${ }^{16}$ MALKIEL-JIRMOUNSKY, Myron, Pintura à Sombra dos Mosteiros, Edições Atica, Lisboa, 1957, pp. 2829.

${ }^{17}$ VÁZQUEZ, Raquel Bello, A Condessa do Vimieiro, Mulheres do Século XVIII, Ela por Ela, FCT, 2006, p. 15. 
coevos - "the history of collecting in Portugal is full of mysteries and a detailed account of the eighteenth century must largely be based on documents and contemporary printed accounts"18 - e não, depreende-se, nas reconstruções historiográficas feitas em épocas posteriores.

Confrontados com estas circunstâncias e cientes das dificuldades, procuramos, tanto quanto possível, socorrermo-nos de documentação coetânea, manuscrita, impressa e iconográfica, suportando certezas em documentação, levantando hipóteses para a reflexão. O objectivo é o de esclarecer, através do caso de estudo da colecção de arte da Rainha D. Carlota Joaquina de Bourbon, o contributo das colecções de arte reunidas no final do Antigo Regime, para a formação dos acervos das instituições museológicas contemporâneas.

Uma vez que este trabalho se restringe ao estudo das colecções de arte de D. Carlota Joaquina de Bourbon, não abordaremos as temáticas relacionadas com a actividade da soberana no campo político, tema que tem despertado o interesse, sobretudo de investigadoras, tanto em Portugal como no Brasil, e sobre o qual existe, actualmente, ampla bibliografia ${ }^{19}$.

18 DELAFORCE, Angela, Art and Patronage in Eighteenth-Century Portugal, Cambridge University Press, 2002.

19 Vejam-se os trabalhos fundamentais de PEREIRA, Sara Marques, D. Carlota Joaquina Rainha de Portugal, Livros Horizonte, 2.a edição, 2008; AZEVEDO, Francisca L. Nogueira de, Carlota Joaquina na Corte do Brasil, Civilização Brasileira, Rio de Janeiro, 2003; Carlota Joaquina Cartas Inéditas, Rio de Janeiro, Casa da Palavra, 2007; ou obras mais antigas, como a de RUBIO, J. M., La Infanta Carlota Joaquina y la Politica de España en America (1808-1812), Biblioteca de Historia Hispano-Americana, Madrid, 1920; ou, mais recente, tais como, VIANA, António; LYRA, Maria de Lourdes Viana, Carlota Joaquina Leopoldina de Habsburgo, Rainhas de Portugal no Novo Mundo, Colecção Rainhas de Portugal, Temas e Debates, Lisboa, 2019; entre muitas outras. 
II - Das colecções privadas aos Museus Públicos

\section{As Colecções de arte D. Carlota Joaquina e os Museus Nacionais. Da esfera privada para o museu público.}

A aquisição de pinturas do Paço do Ramalhão pelo Estado Português, no leilão no Palácio da Bemposta, para a Academia Real de Belas Artes de Lisboa. 0 estado da arte.

O papel de D. Carlota Joaquina enquanto cultora das artes e protectora de artistas, o seu legado enquanto coleccionadora, no qual se deve incluir a colecção de pintura que reuniu no Paço-Quinta do Ramalhão, é hoje inquestionável. À diversa iconografia que testemunha a ligação de D. Carlota Joaquina ao universo cultural e artístico, aliamos a informação documental, guardada nos Arquivos e Bibliotecas Nacionais, que a comprova. A dedicatória que "João Caetano Rivara, Alumno da Real Academia Portuguesa das Bellas Artes em Roma"20, inscreve na gravura que consagra "À Sereníssima Senhora D. Carlota Joaquina, Princesa do Brasil, Infanta de Espanha, Pia Magnanime Augusta" de uma "Imagem de N. Sr. $\underline{\text { a }}$ extrahida do Painel original do Celebre Pintor André del Sarto existente no Gabinete da mesma R. Princesa", é um documento iconográfico de grande relevância, por ser obra de um artista contemporâneo e por tal referência ser anterior a 1816 pois, posteriormente a essa data, (morte da Rainha D. Maria I), a então princesa, torna-se rainha, comprovando a existência de um "Gabinete" de pintura, no qual referencia aquele painel, isto é, de uma colecção de arte, da qual a então Princesa do Brasil era detentora, em data anterior à chegada dos quadros da herança paterna, que só acontece após 1826.

À hora da sua morte em Janeiro de 1830, a Imperatriz-Rainha D. Carlota Joaquina deixava um legado considerável em bens artísticos e patrimoniais. Divergências entre os seus filhos e as costumadas dívidas acumuladas levaram a que, através de hasta pública, se procurassem os meios de saldar aquelas e resolver os diferendos que opunham os descendentes. D. Miguel (1802-1866) que sua Mãe, em disposição testamentária à hora da morte, declarara seu herdeiro universal, seria banido do reino, 1834, pela Convenção de Évora-Monte e os seus direitos objecto de litigância jurídica. A neta D. Maria II (1819-1853), que se propusera ficar

20 João Caetano Rivara (c. 1770-1824), gravador, estudou em Roma e em Londres, com Bartolozzi, regressando a Lisboa em 1803, tornando-se professor de gravura do Jardim Botânico, in MACHADO, Cyrillo Volkmar, Collecção de memórias relativas as vidas dos pintores, e escultores, architectos, $e$ gravadores portugueses e dos estrangeiros que estiveram em Portugal [...], Lisboa, 1823, p. 236. BA. 22VIII-16. Afirma Ernesto Soares, desta gravura apenas conhecer o exemplar existente na Biblioteca Nacional do Rio de Janeiro, v. SOARES, Ernesto, História da Gravura artística em Portugal, 1940, p. 518. Biblioteca da Ajuda, 152-XV-13. 
com o Palácio Quinta do Ramalhão, vira os seus desejos questionados pelos restantes coherdeiros. A hasta pública de todo o recheio e a venda do Paço, a partir de 1847, tornariam doravante mais difícil a reconstrução de um legado agora disperso entre mãos privadas e instituições públicas. Sabemos hoje, no entanto, que o destino de parte da colecção de arte de D. Carlota Joaquina se funde com a criação das instituições museológicas públicas nacionais, como à frente explicitaremos.

\section{II.I - Antecedentes Históricos}

\section{As Origens. Genealogia de uma colecção. O Estado da Arte}

Muito se especulou acerca da origem das colecções de pintura que a Rainha D. Carlota Joaquina reunira e da qual persistem testemunhos nos Palácios e Museus Nacionais, sendo hoje já certo que foram várias as formas e os momentos de incorporação naquela colecção, de entre as quais sobressai o dote de casamento, ofertas e eventuais aquisições e, por fim, a herança de seus pais. A hasta pública realizada a partir de Dezembro de 1847, só deverá ter contemplado uma parte daquele que foi o legado de uma das figuras mais complexas e activas das primeiras décadas do século XIX português e que desempenhou um papel relevante no patronato cultural e artístico.

Durante o século $X X$, a mais persistente de todas as linhas de investigação era a que relacionava a colecção de pintura de D. Carlota Joaquina com a que o Príncipe de Ligne (Charles Joseph de Ligne, 1735-1814) vendera ao Rei D. João VI, por intermédio de D. Lourenço de Lima (1767-1839) ${ }^{21}$, no ano de 1795. Paula Mesquita Santos ${ }^{22}$ refere-a, confundindo, no entanto, o Príncipe de Ligne, Charles Joseph, com o 2. Duque de Lafões ${ }^{23}$ de quem, aliás, era parente.

É provável que a origem desta ideia remontasse ao artigo que o Conde Athanasius Rackzynski (1788-1874) ${ }^{24}$, dedica a "Objets d'Art qui se trouvent en Portugal", na sua vigésima carta

21 "D. Lourenço de Lima foi embaixador em Viena de Áustria antes de o ser em Paris, onde a delegação portuguesa foi elevada à categoria de embaixada quando Napoleão foi proclamado imperador em 1804" in BONIFÁCIO, Maria de Fátima, Memórias do Duque de Palmela, ed. D. Quixote, 2011, p. 99.

${ }^{22}$ SANTOS, Paula Mesquita, obra citada, 1995, p. 293.

${ }^{23}$ D. João Carlos de Bragança e Ligne de Sousa Tavares Mascarenhas da Silva (1719-1806), 2.o Duque de Lafões.

24 O Conde Athanasius Raczynski (1788-1874) desembarcou em Lisboa para exercer funções diplomáticas ao serviço do rei da Prússia, no ano de 1842. Para além das suas funções políticas, desenvolveu actividades de historiador e coleccionador de arte, enviando os seus textos, em forma de Cartas para a Sociedade Artística e Científica de Berlim, onde descreve o estado das Artes em Portugal e 
dirigida à Sociedade Artística e Científica de Berlim, datada de 10 de Maio de $1845^{25}$, na qual, mencionando os quadros antigos do palácio da Ajuda, afirma crer serem os mesmos provenientes, em grande parte, "d'une collection du prince de Ligne", de entre os quais existiriam alguns de boa qualidade. Posteriormente, esta referência, conjugada com a informação contida no artigo de Francisco Cordeiro Blanco ${ }^{26}$, que divulga uma carta inédita que Vieira Portuense, estando em Londres, dirige a D. Rodrigo de Sousa Coutinho ${ }^{27}$, na qual apela a que interceda junto da coroa portuguesa para que esta adquirisse as pinturas que deixara em Itália, propondo Vieira que se fizesse como, "sei fés o Príncipe de Lines dos Países Baixos q tendo em Vienna a sua colleção de Pinturas por via do Exmo Sr. D. Lourenço de Lima cedeu a S.M.F. a d.a Calleria" ${ }^{28}$, ajudou a criar um álibi, que, na ausência de outras pistas, passou a ser a adoptado como o mais plausível para justificar o conjunto de obras de arte de que dispunha D. Carlota Joaquina, no Ramalhão.

Mas, se o Príncipe de Ligne não contribuíra para a colecção de arte da princesa D. Carlota Joaquina, já o mesmo não se pode afirmar no que respeita às colecções de arte do príncipe $D$. João VI, nomeadamente na que deixa no Brasil quando regressa à capital do reino, em $1821^{29}$. Tendo as obras da colecção do Príncipe de Ligne chegado a Portugal, eventualmente, antes da aquisição do Ramalhão pela então Princesa do Brasil, que só se efectua no ano de 1802, é provável a sua dispersão pelos Palácios habitados pela família real e a sua deslocação, bem como de um conjunto vasto de preciosidades, para o Brasil, aquando da travessia atlântica da corte portuguesa.

Se não encontramos nenhuma semelhança de nomes, títulos ou autores entre as pinturas que integravam a colecção do Príncipe de Ligne e o catálogo das pinturas leiloadas na Bemposta, já o mesmo não se pode afirmar quando confrontamos o inventário das obras provenientes do

nas quais fica patente a sua erudição, o gosto pela arte, pelas antiguidades e expedições educativas. V. RODRIGUES, Paulo Simões, "O Conde Athanasius Raczynski e a Historiografia da Arte em Portugal", Revista de História da Arte, n.ㅇ 8, 2011, pp. 264-265.

${ }^{25}$ RACZYNSKI, Le Comte, Les Arts en Portugal, Lettres Adresssés A la Société Artistique et Scientifique de Berlin et accompagnées de documens, Paris, 1846, p. 404. BA 149-XV-88.

${ }^{26}$ BLANCO, Francisco Cordeiro, "Uma Carta Inédita de Vieira Portuense", in Boletim do Museu Nacional de Arte Antiga, Vol. I, n.o 3, Lisboa, 1948, pp. 147-151.

27 D. Rodrigo de Sousa Coutinho (1745-1812), 1. Conde de Linhares, foi Presidente do Erário Régio e Secretário de Estado dos Negócios Estrangeiros e da Guerra. Morreu no Rio de Janeiro.

${ }^{28}$ Em diversa documentação de setecentos, consultada, o termo Galeria é sinónimo de Colecção, e em consequência não significa um espaço específico, mas sim um conjunto de obras de arte, nomeadamente de pintura.

${ }^{29}$ O tema das colecções do Príncipe de Ligne e da sua importância na colecção de pintura que D. João VI deixa no Brasil será objecto de um estudo autónomo. 
Ramalhão com aquela que é denominada "Tercera Division", debaixo da rubrica "Cuadros adjudicados a la Serenissima Señora Ynfanta de España Doña Carlota Joaquina de Borbon, Reyna Viuda de Portugal, por la Testamanaria de los Señores Reyes Padres, en el año de $1826^{\prime 30}$, manuscrito da Biblioteca da Ajuda que identifica as 135 pinturas herdadas, provenientes de Roma, com passagem por Madrid. Apesar das cópias existentes na Biblioteca da Ajuda não disporem das dimensões das obras, a partir dos títulos e das autorias ensaiaremos uma relação entre as provenientes daquela herança e as levadas a leilão no Palácio da Bemposta, incluídas no catálogo Relação dos Quadros pertencentes á Herança da Imperatriz Rainha a Senhora D. Carlota Joaquina de Bourbon, hoje existentes no Real Palacio da Bemposta, onde hão-de ser vendidos em hasta publica, perante o Juiz do respectivo Inventario [...] e que forão descriptos e avaliados pelos Senhores António Manoel da Fonseca, Lente de Pintura Histórica da Academia das Bellas Artes de Lisboa, e Luiz Tirinnanzi, Pintor restaurador de quadros [...], assinado pelo Solicitador da Caza Real, Francisco de Caldas Aulete, Lisboa, $1843^{31}$.

\section{II.II - A hasta pública no Palácio da Bemposta}

A hasta pública no Palácio da Bemposta, em Lisboa, do espólio da Imperatriz Rainha proveniente do Palácio do Ramalhão, no qual se incluíam as colecções de arte, motivou um amplo debate na sociedade portuguesa de então - "Hoje não se pode nem deve ficar silencioso quando se sabe que as nossas obras-primas, riqueza de Portugal, correm perigo de ir, a baixo preço, enriquecer os museus estrangeiros [...]", foi o apelo patriótico lançado no n.․․ 109 do periódico O Panorama 32 , de 27 de Janeiro de 1844 que, com o título apelativo "Um Brado a Favor da Gloria Nacional e das Bellas Artes", assinado por S. J. Ribeiro de Sá, fazia eco de um sentimento público generalizado pela falta de uma Galeria Nacional, ou de um Museu Público, onde as pinturas pudessem ser exibidas, servindo, desse modo, a formação do gosto artístico e instrução dos cidadãos, assim se evitando o perigo, então temido, de as ver sair para o estrangeiro.

O Conde Rackzynski ao referir a exposição daquele espólio, no Palácio da Bemposta, em momentos que antecederam o leilão, cita aquele artigo no qual é lamentada falta de uma

\footnotetext{
${ }^{30}$ BA 54-X-33 (7). Trata-se de um documento inédito, não estudado até à data.

${ }^{31}$ Devo à generosidade do Dr. Miguel Figueira de Faria a cópia sobre a qual trabalhei, antes de ter localizado a transcrição do documento na Revista Universal Lisbonense, Tomo VII, 1847-1848.

32 O Panorama, n. 109, 27 de Janeiro de 1844. Citado por Rackzynski, RACKZYNSKI, Le Comte A., Les Arts en Portugal, Lettres Adressées a la Societé Artistique et Scientifique de Berlin [...], Paris, 1846, p. 280.
} 
galeria nacional que pudesse acolher as obras de arte que "font partie de la succession de la reine Dona Carlota Joaquina" ${ }^{33}$, passando de imediato a descrever cada uma das pinturas que O Panorama mencionava, fazendo a sua crítica como "connoisseur" e amante das belas artes.

O periódico A Carta, em Dezembro de $1847^{34}$, fazendo eco daquelas preocupações, lançava igual "brado" a favor da aquisição das obras de arte pelo Estado português "como tanto convinha ao decoro nacional ${ }^{\prime 35}$. Era então associada a riqueza nacional ao conjunto de obras de arte de que o país dispunha, sendo a sua venda para o estrangeiro considerada como perda nacional.

A existência de um espaço no qual aquele conjunto de obras pudesse ficar exposto, evitando a sua inevitável passagem para o estrangeiro ${ }^{36}$, era um desejo que há muito fermentava, pois, segundo $O$ Panorama, estes "quadros dos grandes mestres [...] poderiam servir, para junto com o pouco que de outras idênticas circumstancias nos tem restado, principiarmos a organização de uma galeria nacional, tão necessária e que sem grande sacrifício poderia ser levada a cabo" ${ }^{37}$.

A fundação da Academia Real de Bellas Artes, no Convento de S. Francisco, em Lisboa, em 1836, constituíra um passo significativo para a concretização daquele desígnio. Seria agora necessário que o Governo e as Cortes se pronunciassem sobre aquele "importantíssimo objecto" pois, segundo S. J. Ribeiro de Sá "Portugal pode perder muito das suas honras de paiz civilizado, ou ganhar bastante do que já tem perdido", não deixando de associar "a gloria da nossa pátria", ao "esplendor das Bellas-Artes"38.

\footnotetext{
${ }^{33}$ RACZYNSKI, Le Comte A., Les Arts en Portugal, Lettres Adressées a la Societé Artistique et Scientifique de Berlin [...], Paris, 1846, p. 280.

${ }^{34}$ A Carta, n.o 70, 13 de Dezembro de 1847, refere o início do leilão "quinta feira 9 começou o importante leilão do espolio da senhora imperatriz rainha D. Carlota Joaquina de Bourbon, no real palácio da Bemposta. É um dos mais valiosos leilões que ha muito não temos, ou talvez que nunca houve - porque é um leilão realengo. Parece que as joias, ouro e prata estão avaliadas em perto de $20.000 \$ 000$. A mobília, louça, cristaes etc. Em $12.000 \$ 000$ reis. Os quadros e objectos de arte em $9.600 \$ 000$ réis. E as quintas do Ramalhão e outras em $100.000 \$ 000$ réis [...]".

${ }^{35}$ A Carta, n.o 70, 13 de Dezembro de 1847.

${ }^{36}$ Rackzynski, obra citada, p. 280.

${ }^{37}$ O Panorama, vol. 3.o, Série 2.a, Lisboa, Jan./Dez. 1844, pp. 27-28.

${ }^{38}$ Idem, ibidem.
} 
A Revista Universal Lisbonense ${ }^{39}$ ia mais longe naquele desígnio pois, debaixo do título "Os quadros da Bemposta e a possibilidade de organizar em Lisboa um Museu Nacional", transcrevia o catálogo das obras, com a descrição dos títulos, autorias e valores base de licitação. 0 catálogo ${ }^{40}$, assinado pelo solicitador da Casa Real José Caldas Aulete, era datado de 20 de Dezembro de 1843, e impresso em 1844, e tornara-se um documento raro, o que justificava agora aquela iniciativa, bem como o facto de "aquela ser a venda mais importante de objectos de Bellas Artes, que entre nós se tem feito", assim escrevia o redactor do artigo, formulando votos de que o "Governo e as Cortes atendam às justas reclamações que tanto urgem, de compra desta collecção pelo baixo preço por que se vende" ${ }^{\prime 1}$.

Os diversos "brados" lançados pela opinião pública, e publicada, colheriam frutos, pois seria no próprio Convento e no seio da Academia que, em 1868, mais de trinta anos após a sua fundação, aquele desígnio seria, em parte, cumprido, com a inauguração da Galeria Nacional de Pintura, na qual estiveram expostos cerca de 366 quadros, segundo Ayres de Carvalho ${ }^{42}$, com diversas proveniências, de entre os quais sobressaíam os oriundos da colecção da Imperatriz Rainha, adquiridos pelo Estado português, em 1848, no leilão da Bemposta.

Para aquele objectivo muito contribuíra o empenho dos membros da Academia que, reunidos em 15 de Janeiro de 1844, em assembleia, manifestaram a intenção de dirigirem "uma representação ao Governo, pedindo que se comprassem por conta do Estado os [quadros] que fossem originaes clássicos" para "se utilizarem na Academia, evitando-se que" [fossem] "para fora do Reino". Tendo, então, manifestado "o IIImo. Director"43 o intento de ir "pessoalmente

\footnotetext{
${ }^{39}$ Revista Universal Lisbonense, Imprensa da Gazeta dos Tribunais, Tomo VII, 1847-1848, Lisboa, 27 de Abril de 1848, pp. 241-246 e 4 de Maio 1848, pp. 254-258.

${ }^{40}$ Relação dos Quadros pertencentes á Herança da Imperatriz Rainha a Senhora D. Carlota Joaquina de Bourbon, hoje existentes no Real Palacio da Bemposta, onde hão-de ser vendidos em hasta publica, perante o Juiz do respectivo Inventario [...] e que forão descriptos e avaliados pelos Senhores António Manoel da Fonseca, Lente de Pintura Histórica da Academia das Bellas Artes de Lisboa, e Luiz Tirinnanzi, Pintor restaurador de quadros [...], assinado pelo Solicitador da Caza Real, Francisco de Caldas Aulete, Lisboa, 1844. Revista Universal Lisbonense, Tomo VII, 1847-1848.

${ }^{41}$ Idem, ibidem, p. 242.

42 CARVAlHo, Ayres, A Galeria Nacional de Pintura da Academia Real das Belas-Artes (1868) - o catálogo do Marquês de Sousa Holstein, Lisboa, 1982, p. 33.

${ }^{43}$ Francisco Assis Rodrigues (1801-1877) era na ocasião Director Geral da Academia. José Fernandes Pereira refere a admiração do artista pela figura de D. Fernando de Saxe Coburgo, Rei-Consorte e Regente, após a morte de D. Maria II, em 1853, e até à maioridade de seu filho D. Pedro V, em 1855. In PEREIRA, José Fernandes, "Francisco de Assis Rodrigues ou o mal-estar de um clássico entre românticos", Arte teoria, Faculdade de Belas Artes, Lisboa, 2000, pp. 80-87.
} 
fallar a Sua Magestade a respeito deste objecto"44 e, "sendo geralmente adoptada a opinião, resolvêo a Conferencia que se fizesse a dita representação com toda a urgência".

Sensibilizadas as autoridades para a importância daquele espólio, foi obtida a anuência do Governo para a aquisição de vinte e cinco pinturas e dois baixos-relevos, o que foi efectuado a 23 de Maio de 1848, segundo recibo assinado pelo "solicitador da herança", Julião Paulino Figueiredo Costa, tendo na ocasião sido entregue a verba de "R.s.1.000\$000"45. No entanto, bastantes anos decorridos, ainda andavam, nas arrecadações do Real Palácio da Bemposta, as obras arrematadas pelo Estado português. As deficientes condições de armazenamento, a degradação a que estavam sujeitos levou, na ocasião, os membros da Academia a apelarem aos herdeiros da Imperatriz-Rainha para que libertassem as pinturas que ali se arruinavam. A falta de meios financeiros, por parte do Governo, para satisfazer o pagamento da verba remanescente, levara a protelar a entrega das obras, pois a promessa de pagamento por "Aviso de Crédito", apresentada pelo Conde de $\operatorname{Tomar}^{46}$, por carta de 6 de Setembro de $1849^{47}$, fora recusada pelo vedor da Casa Real, D. Manuel de Portugal e Castro ${ }^{48}$, que exigia que a liquidação daquelas quantias fosse feita, em metal, e não conforme proposto.

Em 30 de Dezembro de 1850, de novo, vinha o Conde de Tomar dar notícia, ao representante da Família Real, de que "naquele mesmo dia dirigi[ra] ao Ministerio da Fazenda a requisição de credito certo [...] de $3.665 \$ 200$ saldo em dívida da referida arrematação" informando de que Ihe seria "imediatamente enviada a competente ordem de pagamento logo que pelo sobredito Ministério" Ihe fosse remetido o respectivo aviso de crédito, fazendo votos para que enquanto se não terminasse aquele "negocio" fossem empregues todos os cuidados e "desvelos para que os sobreditos quadros e mais objectos existentes no Real Palácio da Bemposta" fossem guardados de maneira a não sofrerem "deterioração ou descaminho"49.

\footnotetext{
${ }^{44}$ Naquela ocasião era ainda viva D. Maria II que reinou até ao ano da sua morte, em 1853. D. Fernando de Saxe Coburgo ocupou a partir dessa data a regência do Reino, face à menoridade de seu filho $D$. Pedro (1837-1861).

${ }^{45}$ ANTT, Casa Real, Cx. 7100, XX/2/81 (18).

46 António Bernardo da Costa Cabral (1803-1889), 1.o Conde (em 1845) e 1.o Marquês de Tomar, assumiu a pasta da Justiça, em 1845, sendo ministro do Reino, em 1846.

47 ANTT, AHMF, Cx. 7327. Cartas de 6 e 13 de Setembro de 1849 e 30 de Dezembro de 1850, dirigidas pelo Conde de Tomar, a D. Manuel de Portugal e Castro, Vedor da Casa Real.

48 D. Manuel de Portugal e Castro (1787-1854) era igualmente representante de D. Maria II que ficara como cabeça- de-casal da herança de sua avó.

${ }^{49}$ ANTT, AHMF, Cx. 7327, carta de 30 de Dezembro de 1850.
} 
Pela correspondência percebemos ter sido envolvido naquela demanda a figura de "S. Magde El Rey Regente" ${ }^{50}$, o que não terá sido indiferente para o bom desfecho daquele "negócio". Pela carta datada de 17 de Julho de 1854, se escrevia que "Manda Sua Magestade El Rey Regente, em nome do Rey, que o Procurador Régio da Rellação de Lisboa faça promover quanto for conducente para que os referidos quadros e objectos confiados [...] à guarda do Almoxarife do dito Palácio [...] sejão depositados, com as solemnidades legaes, na Academia das Bellas Artes de Lisboa, enquanto o Governo não se habilitar com as authorizações de que carece, para remir o preço total porque foram comprados [...]"51. Tal pedido seria, no entanto, recusado, pois justificava-se "o solicitador Julião Paulino Fig. Costa", que não era "desobedecer-Ihe [a S. Mag.de El Rey Regente] o impugnar a entrega dos Quadros e objectos artísticos não pagos" ${ }^{\prime 2}$.

Fora preciso aguardar mais cinco anos para que a situação se resolvesse. Assim, no ano de 1859, por “Portaria do Conselho Superior d'Instrução Publica de 11 de Fevereiro, acompanhada do Edital [...]; d'um officio do Conde da Ponte [...]", ordenava-se "ao Almoxarife do Real Palácio da Bemposta posesse à desposição" daquela "Academia os quadros que se acham arrecadados no dito Palácio, pertencentes ao espolio da fallecida Imperatriz Rainha D. Carlota Joaquina de Bourbon, que foram arrematados por ordem do Governo para a mesma Academia", conforme constava da Acta 481, "da conferência ordinária da Academia de Bellas Artes de Lisboa", datada de 30 de Março de $1859^{53}$.

O recibo assinado por Francisco Assis Rodrigues, então director-geral da Academia de Belas Artes de Lisboa, datado de 18 de Abril, que o então Almoxarife do Real Palácio da Bemposta dirige ao Conde da Ponte, na ocasião Vedor da Casa Real, vem confirmar a entrega. Era redigido nestes termos: "Incluso remeto a V.a Ex. o o duplicado que o Director Geral das Bellas Artes, Francisco de Assis Rodrigues, entregou na ocasião da recepção dos quadros pertencentes ao hespólio da Imperatriz Rainha Senhora Dona Carlota Joaquina de Bourbon que forão arrematados pelo Governo de Sua Magestade para uso da mesma Academia. [...].

\footnotetext{
50 D. Fernando de Saxe Coburgo Gotha (1816-1885). Com a morte da rainha D. Maria II, em 1853, assume a regência do reino, em nome de seu filho, futuro D. Pedro V (1837-1861), até à maioridade deste, em 1855.

${ }^{51}$ ANTT, AHMF, Cx. 7327, cópia do requerimento datado de 10 de Julho de 1854, assinado por Frederico Guilherme da Silva Pereira (Monção, 1806-Lisboa 1871), Ministro com a pasta da Justiça e dos Negócios Eclesiásticos do Governo regenerador do Marechal Saldanha (1853-1856).

${ }^{52}$ ANTT, AHMF, Cx. 7327, carta do solicitador Julião Paulino Figueiredo Costa, datada de 17 de Julho de 1854.

${ }^{53}$ ANBA, 1-A-SEC. 011, Acta 481, 30 de Março de 1859.
} 
Bemposta, 18 de Abril de $1859^{\prime \prime 54}$. Este recibo acompanhava uma lista com informação detalhada sobre cada uma das obras recebidas na Academia (tema, suporte e dimensões), datada de 11 de Abril daquele mesmo ano. Isto é, quase onze anos volvidos sobre a sua arrematação.

A Acta n.o 482, relativa à sessão da Academia de Bellas Artes de Lisboa, do dia 28 de Abril de 1859, refere a consulta daquela assembleia "a respeito dos quadros que pertenceram ao espolio da fallecida Imperatriz Raynha D. Carlota Joaquina de Bourbon e que foram comprados para uso d'esta Academia", sendo posto à consideração, "em primeiro logar: - se a conferencia convinha em se restaurarem algumas faltas de tinta que havia em alguns dos referidos quadros", assentando, "depois d'alguma discussão [...] que convinha primeiro que tudo que a mesma Conferencia fosse examinar miudamente cada um dos mencionados quadros, e que se lavrasse uma acta para que em todo o tempo constasse qual o estado em que os ditos quadros foram recebidos [...]". Daqui se confirma estarem já, em Abril de 1859, os objectos à guarda da Academia Real de Belas Artes de Lisboa, e às mãos dos restauradores para, segundo se lê, "entretanto continuarem a ser limpos do pó e envernizados com o bom verniz de goma Almecega pelo artista António Caetano da Silva e dirigido pelo Professor proprietário da Aula de Pintura Histórica"55, na ocasião António Manuel da Fonseca (17961890), que ocupava aquele lugar, desde 1836.

II.III - Da Academia de Belas Artes, no Convento de S. Francisco de Lisboa, ao Museu de Bellas Artes e Archeologia, nas Janelas Verdes.

Desde meados do século XIX que a venda do conjunto de obras de arte que pertenceram ao espólio do Ramalhão estimulara o debate público sobre a urgência da criação de um Museu de Belas Artes, em Lisboa. Os museus eram instrumentos capitais para a instrução pública e determinantes para a afirmação identitária, num período em que os nacionalismos adquirem centralidade. O debate sobre a urgência na sua criação envolveu grande parte da intelectualidade portuguesa, como testemunham os diversos artigos que surgiam na imprensa periódica de então. A extinção das ordens religiosas e a desarmortização dos conventos, em 1834, a ruína e dispersão a que muito do património das casas religiosas estava sujeito, o empobrecimento das elites do Antigo Regime e a venda do património das casas senhoriais, em sucessivas hastas públicas, estimulava a discussão.

\footnotetext{
${ }^{54}$ ANTT, AHMF, Cx. 7327, carta do Almoxarife do Real Palácio da Bemposta, 18 de Abril de 1859.

${ }^{55}$ ANBA, 1-A-SEC. 011, Acta n.o 482, relativa a sessão do dia 28 de Abril de 1859.
} 
O Marquês de Sousa Holstein ${ }^{56}$, pioneiro da reflexão museológica em Portugal, na sua introdução ao "Catálogo Provisorio da Galeria Nacional de Pintura existente na Academia Real das Bellas Artes de Lisboa", em 1872, não deixa de reflectir sobre essa questão, afirmando que o que "Portugal pode e deve ainda ter são museus nacionais, representando a historia das suas artes e contendo as produções mais notáveis dos seus artistas" ${ }^{\prime 2}$. Uma parte da colecção estaria já formada, "na quinta sala da galeria da Academia Real das Bellas Artes", para onde fora dirigido muito do espólio artístico dos antigos conventos e mosteiros nacionais. Segundo aquele académico bastaria "augmentar esta colecção, adicionar exemplares que andam dispersos pelo paiz", que "chronologicamente dispostos permitissem compreender a evolução da "arte nas phases porque passou na nossa terra". A comparação daquelas obras com outras de autores estrangeiros permitiria, por método comparativo, completar o conhecimento sobre a "história das artes em Portugal"58.

As aquisições efectuadas pelo Governo português, no leilão da Bemposta, enquadravam-se naquele espírito, profundamente empenhado na criação de instituições que promovessem o progresso cultural e a instrução pública. Incorporadas as obras, em 1859, na Academia Real, ao Convento de S. Francisco, integraram, em 1872, o mencionado catálogo, o qual se limitava a dar alguma indicação "em geral [d]o assunto do quadro, a substancia sobre que é pintado, as suas dimensões e a sua proveniência", sem maior desenvolvimento historiográfico ou interpretativo. De entre as quatro, ou cinco, proveniências das obras aí apresentadas surgia, logo em segundo lugar, "D. Carl. Joaq.", referente aos "Quadros comprados em 1859, do espolio da senhora D. Carlota Joaquina"59, seguida da referência a "D. Fern. - Quadros comprados nos anos de 1865, 1866, 1867 e 1868 com as somas que sua Magestade el-rei o senhor D. Fernando cedeu para este fim, da sua dotação" ${ }^{\prime 60}$. Os soberanos, ambos estrangeiros, assumiam a sua quota-parte na formação da primeira instituição museológica de Lisboa.

\footnotetext{
${ }^{56}$ D. Francisco de Borja Pedro Maria António de Sousa Holstein, Marquês de Sousa Holstein, 13. filho do primeiro Duque de Palmela, nasceu em Paris em 1838, morrendo em Lisboa em 1878. Foi ViceInspector da Academia Real das Belas Artes de Lisboa. V. XAVIER, Hugo, O Marquês de Sousa Holstein e a formação da Galeria Nacional de Pintura da Academia de Belas Artes de Lisboa. Teses de Doutoramento em História da Arte, FCSH, Julho de 2015. http://hdl.handle.net/10362/15313. Consulta online Janeiro 2019.

${ }^{57}$ Marquês de Sousa Holstein, Catalogo Provisorio da Galeria Nacional de Pintura existente na Academia Real das Bellas Artes de Lisboa, 2.a edição, Lisboa, 1872, p. 16.

${ }^{58}$ Idem, ibidem, p. 21.

${ }^{59}$ Catalogo Provisorio da Galeria Nacional de Pintura existente na Academia na Academia Real das Bellas Artes de Lisboa, 2.a edição, Lisboa, 1872, p. 7.

${ }^{60}$ Idem, ibidem.
} 
$\mathrm{Na}$ introdução ao Catálogo Provisório [...], o vice-inspector enaltecia a criação daquele estabelecimento esperando que a publicidade que sobre si suscitasse fosse capaz de fazer sair do alheamento os poderes públicos e que os "anim[ass]e a ser um pouco menos parcos nos subsídios concedidos as bellas artes". A penúria de meios só fora esporadicamente ultrapassada com as doações que D. Fernando da Saxe Coburgo (1816-1885) ia fazendo, da "sua dotação pessoal", verba aplicada na aquisição de pinturas. Mas, queixava-se o Marquês de Sousa Holstein, a falta de meios fizera com que se perdessem "muitas ocasiões, que não mais voltarão, para segurar á nação, por preço modico, a posse de obras de arte de indisputável merecimento", pois "a extinção ou decadência de muitas famílias antigas levava constantemente ao mercado um grande numero de obras de arte que fôra fácil e pouco dispendioso adquirir", lamentando ser o nosso país "quasi o único em que a fundação dos museus e galerias não tem encontrado as geraes sympathias", justificando tal situação com o facto de, para muitos, ser a arte "uma superficialidade da qual não deve cuidar-se emquanto o nosso paiz lutar com deficit" ${ }^{\prime 61}$, o que, podemos afirmar, ser um diagnóstico antigo, para um mal persistente...

O arrendamento do Palácio Alvor, às Janelas Verdes, em 1879, e a apresentação da Exposição Retrospectiva de Arte Ornamental Portuguesa e Hespanhola, em Janeiro de 1882, foram os acontecimentos que antecederam e desencadearam o processo de abertura em 1884, do então Museu Nacional de Bellas Artes e Archeologia, mais tarde renomeado, pela legislação republicana, como Museu Nacional de Arte Antiga, em 1911.

Com a fundação deste pólo museológico às Janelas Verdes, que abre as suas portas a $12 \mathrm{de}$ Junho de 1884, a colecção de pintura da Academia ali encontraria um lugar de exposição adequado, satisfazendo as aspirações de um público que há muito exigia a criação de um museu nacional dedicado às belas artes.

Nesta readaptação de uma Casa Senhorial às funções de Museu Nacional, as obras de arte outrora pertencentes à colecção da Imperatriz-Rainha, encontrariam o seu lugar enquanto "obras-primas", espalhadas pelas diversas salas, nas quais as pinturas eram apresentadas integrando "Escolas", à falta de identificação mais rigorosa.

${ }^{61}$ HOLSTEIN, Marquês de Sousa, "Introdução", Catalogo Provisorio da Galeria Nacional de Pintura existente na Academia na Academia Real das Bellas Artes de Lisboa, 2.a edição, Lisboa, 1872, p. 15. 
A presença da Imperatriz-Rainha continuava a afirmar-se, não agora pelas suas posições no campo político, mas pelo seu legado patrimonial e artístico, de que as actuais instituições públicas portuguesas são tributárias.

Esse núcleo de obras de arte que a soberana reuniu tem sido, recentemente, objecto de diversos estudos no âmbito do coleccionismo e da História da Arte, tanto em Portugal, como em Espanha, em consequência da reavaliação do papel das elites do Antigo Regime, nestes domínios específicos. Novos dados podem, porém, ser acrescentados aos trabalhos recentemente editados, pois persistem dúvidas e mantêm-se interrogações.

Parece, no entanto, irrecusável o facto de D. Carlota Joaquina ter dado um contributo indelével para a formação das primeiras instituições museológicas nacionais, ainda que indirecta, pois as obras de arte das suas colecções ocupam nelas um lugar destacado.

\section{II.IV - A Colecção de D. Carlota Joaquina e os Estudos no âmbito Museológico}

Depois de, no século XIX, a hasta pública do conjunto de preciosidades que integrou o legado de D. Carlota Joaquina de Bourbon ter suscitado o interesse de quantos pugnavam pela constituição de um Museu Nacional, no século XX continuou o mesmo a atrair um significativo número de estudiosos com interesse no campo do coleccionismo privado de Antigo Regime, e do seu impacto na formação dos museus públicos. Dos investigadores e museólogos, que se debruçaram sobre o percurso daquelas obras de arte, tentando traçar uma genealogia, foi pioneiro o trabalho de Paula Mesquita Santos, "A Colecção de Pintura de D. Carlota Joaquina de Bourbon, Oriunda do Ramalhão, em Sintra. O seu resultado na formação do Museu Nacional de Arte Antiga”62, publicado na revista Vária Escrita, editada em 1995.

Neste, a autora dá continuidade a trabalhos realizados ao longo do século XIX, compilando referências dispersas, com o objectivo de acompanhar o percurso das pinturas, desde o Palácio do Ramalhão, até à almoeda no Palácio da Bemposta e desta à incorporação, de parte, no acervo da Academia Real de Bellas Artes e a sua posterior integração no actual Museu Nacional de Arte Antiga ${ }^{63}$.

\footnotetext{
62 SANTOS, Paula Mesquita, "A Colecção de D. Carlota de Bourbon, oriunda do Ramalhão, em Sintra [...]", in Vária Escrita, n.o 2, Sintra 1995, pp. 261-312.

${ }^{63}$ De entre as fontes citadas nas quais a autora se apoia, destacam-se, entre outros, os artigos de SÁ, J. Ribeiro de, "Um Brado a Favor da Gloria Nacional e das Bellas-Artes", O Panorama, Vol. 1, 3.ㄹ, Série 2. Lisboa, Jan/Dez de 1844, pp. 27-28, e "Almoeda no Palácio da Bemposta", na Revista Universal Lisbonense, Imprensa da Gazeta dos Tribunais, Tomo VII, 1847-1848, Lisboa, pp. 19-21; o artigo
} 
Questionando a origem daquela colecção, socorrendo-se para o seu estudo de referências dispersas, publicadas em diversos periódicos tardo-oitocentistas e novecentistas, chama, de igual modo, a atenção para documentação guardada nos ANTT, até aí não trabalhada. Mesmo contendo erros, nomeadamente no que à origem daquele conjunto respeita, constituiu uma etapa importante no despertar de um renovado interesse sobre as colecções de arte da Imperatriz-Rainha e do seu contributo para a formação das colecções museológicas nacionais.

Mais recentemente Celina Bastos, museóloga e investigadora do Museu Nacional de Arte Antiga, a propósito da apresentação da pintura "Êxtase de S. Francisco", de Luca Giordano, pertencente ao acervo daquele museu faz, em "Percurso de uma Pintura" ${ }_{64}$, um levantamento minucioso do processo relativo ao inventário do espólio do Palácio do Ramalhão, da hasta pública no Palácio da Bemposta e das aquisições aí efectuadas pelo Estado português, bem como dos procedimentos relacionados com as partilhas dos Reis de Espanha, Carlos IV e Maria Luísa de Parma, mortos no exílio italiano no ano de 1819 (Maria Luísa, a 2 de Janeiro e Carlos IV, a 19 do mesmo mês) e da sequente reivindicação por parte de D. Carlota Joaquina, da sua quota-parte hereditária, socorrendo-se quer de documentação existente nos ANTT, por si levantada, quer dos estudos dos investigadores espanhóis Miguel Hermoso Cuesta (2005, 2010) e Carmen Garcia-Frias Checa (2011). O seu trabalho constitui mais uma importante etapa para o esclarecimento do processo de formação e dispersão de uma das maiores colecções artísticas privadas, no Portugal de oitocentos.

publicado no periódico $A$ Carta, no ano de 1847; e já no século XX, "Os Quadros do Ramalhão que foram para a Academia de Belas Artes", SARAIVA, José da Cunha, Feira da Ladra, vol. 7, 1936-1937, pp. 165177.

${ }^{64}$ BASTOS, Celina; CAETANO, Joaquim Oliveira, Luca Giordano. Êxtase de São Francisco, MNAA, Março de 2014. Deve aqui ser destacado o trabalho de levantamento sistemático e rigoroso levado a cabo pela Dr.a Celina Bastos, conservadora-investigadora do Museu Nacional de Arte Antiga que muito tem contribuído para a divulgação de documentação inédita existente nos Arquivos Nacionais, relativamente à Casa da Rainha D. Carlota Joaquina de Bourbon. BASTOS, Celina, "Os interiores régios de D. Maria I a D. Maria II», in SOUSA, Gonçalo Vasconcelos e (dir.), Matrizes da Investigação em Artes Decorativas. V, Porto, Universidade Católica do Porto/ CITAR, 2013, pp. 115-145; BASTOS, Celina, FRANCO, Anísio, «Para Memória Futura: Interiores Autênticos em Portugal», in MALTA, Marize, MENDONÇA, Isabel M. G. (org.), Casas senhoriais Rio-Lisboa e seus interiores, Estudos Luso-brasileiros em Arte, Memória e Património, Lisboa/ Rio de Janeiro, Universidade Federal do Rio de Janeiro/ Universidade Nova de Lisboa/ Fundação Ricardo do Espírito Santo Silva, 2013-2014, pp. 69-103. Uma palavra de agradecimento é devida a esta investigadora pelas palavras de estímulo com que, ao longo destes últimos anos, tem animado a signatária a prosseguir no trabalho de levantamento documental e divulgação da informação por si reunida, sobre esta temática. 
O primeiro, Miguel Hermoso Cuesta, no seu ensaio "A propósito de un lienzo de Lucas Jordán en el Museu Nacional de Arte Antiga de Lisboa" ${ }^{65}$, dedicado à obra do artista napolitano Luca Giordano (1634-1705), estabelece um paralelo entre esta obra, proveniente de Espanha e pertencente às colecções de D. Carlota Joaquina, e que actualmente integra o acervo do Museu Nacional de Arte Antiga, e outras pinturas do mesmo autor, de idêntica temática, que se encontram em museus internacionais. De igual modo, chama, pela primeira vez, a atenção para documentos existentes nos Arquivos espanhóis respeitantes à contestação da rainha portuguesa, relativamente a esta pintura de Luca Giordano que Ihe fora atribuída nas partilhas do espólio dos reis seus pais ${ }^{66}$, mas que tardava a chegar à sua posse. Em documento, datado de 4 de Janeiro de 1827 que transcreve, é mencionada a figura de D. Alfonso de Yevenes ${ }^{67}$, "como encargado por los S.res herederos y testamentários del difunto Sr. Duque de Montemar,

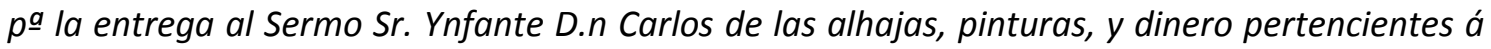

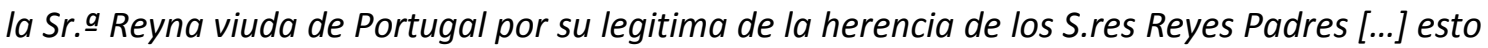
y en el caso de manifestar a V. S. : Que una pintura del descendim.to de Nuestro Señor, y de dha pertinência, obra maestra de Jordan, señalada com el Num. 92 existe en el Museo"68. 0 facto de a pintura se conservar em Espanha, na "Galeria de pinturas del Museo", por razões ditas de necessidade de restauro, tardara a sua entrega, pois, segundo a direcção do museu "quando se llebó a este Establecimento se hallaba en un Estado ruinoso por cuya razon se le forro de nuebo, se le puso un buen bastidor y se le preparo para restaurar". Conforme a documentação que o autor transcreve, face às demandas da rainha D. Carlota Joaquina, as ordens foram, então, para que a pintura fosse entregue, no estado em que se encontrava, a D. Ambrosio Plazaola, enquanto representante de "S. M. la Señora Reyna viuda de Portugal a quien le há sido adjudicado"69, segundo se escrevia.

Esta última temática, a herança dos "Reis pais", tem sido, de igual modo, objecto de atenção por parte da investigadora Carmen Garcia-Frias Checa, que divulgou importante informação no seu artigo "Nuevas aportaciones al estúdio de la colección pictórica de Carlos IV en el exilio"70, no qual esclarece o processo de partilhas dos Reis e das quotas-partes hereditárias dos irmãos

${ }^{65}$ CUESTA, Miguel Hermoso, “A propósito de un lienzo de Lucas Jordán en el Museu Nacional de Arte Antiga de Lisboa", Anales de Historia del Arte, 2010, pp. 183-207.

${ }^{66}$ BA ms. 54-X-33.

${ }^{67}$ CUESTA, Miguel Hermoso, 2010, pp. 198.

${ }^{68}$ CUESTA, Miguel Hermoso, 2010, apêndice documental, docs. 9, 10, 11, pp. 203-205.

${ }^{69}$ Documentos citados por M. H. Cuesta, no apêndice documental do texto citado, docs. 14 e 15, pp. 206-207.

${ }^{70}$ CHECA, Carmen García-Frías, "Nuevas aportaciones al estúdio de la colección pictórica de Carlos IV en el exilio", in Carlos IV y el arte de su reinado, Actas de las Jornadas de Arte e Iconografia, Fundación Universitaria Española, Outubro, 2011, pp. 211-261. 
da rainha portuguesa, o rei Fernando VII e dos infantes, seus irmãos e irmãs. Da análise desta investigadora resultou, segundo a própria, "un avance significativo en las investigaciones para la historia del colecionismo de Carlos IV en el exilio", no qual se deve incluir a quota-parte herdada por D. Carlota Joaquina, pouco tempo antes de sua morte, ocorrida em 1830.

A revelação dos documentos relativos à herança de Carlos IV e Maria Luísa de Parma, e das consequências desta nas colecções da Rainha portuguesa, despoletou novas interrogações sobre a proveniência das obras que integravam a colecção de pintura de D. Carlota Joaquina, suscitando novos estudos e abordagens. Ficava clara a importância da quota-parte da herança paterna naquelas, mas não respondia pela totalidade do legado da Imperatriz Rainha.

Mais recentemente, Hugo Xavier na sua tese de Doutoramento, "O marquês de Sousa Holstein e a formação da Academia de Belas Artes de Lisboa"71, inclui um capítulo dedicado à colecção de pintura de D. Carlota Joaquina e ao processo da sua "incorporação" naquela instituição; e Clara Moura Soares em "Os Recheios do Paço do Ramalhão (Sintra, Portugal): A Herança e o Gosto Artístico da rainha D. Carlota Joaquina de Bourbon"72, texto apresentado em Simpósio internacional, faz uma síntese dos estudos editados sobre esta temática, focando o impacto da herança paterna no recheio do Ramalhão, na linha dos estudos anteriormente citados.

Em resumo, os trabalhos até agora editados dão especial ênfase à colecção de pintura de $D$. Carlota Joaquina, às vicissitudes relacionadas com a compra pelo Estado português de um conjunto de pinturas, para reforço da componente pedagógica e de valorização das colecções de arte da Academia de Belas Artes de Lisboa e, a posterior incorporação daquelas no acervo do Museu Nacional de Arte Antiga, de Lisboa. A revelação, por parte dos investigadores espanhóis, de fontes provenientes dos arquivos de Espanha, permitiu aprofundar o conhecimento sobre a genealogia de parte de um legado, até então envolto em incógnitas.

71 XAVIER, Hugo, "O Marquês de Sousa Holstein e a formação da Galeria Nacional de Pintura da Academia de Belas Artes de Lisboa", Tese de Doutoramento em História da Arte, FCSH: DHA, Lisboa, 2015. Consulta online.

72 SOARES, Clara Moura, "Os Recheios do Paço do Ramalhão (Sintra, Portugal): A Herança e o Gosto Artístico da rainha D. Carlota Joaquina de Bourbon", comunicação apresentada no VIII Seminário do Museu D. João VI, IV Colóquio Internacional Colecções de Arte em Portugal e Brasil Nos Séculos XIX e XX. Arte e seus Lugares: Coleções em Espaços Reais, 2017, pp. 11-32. https://www.academia.edu/37438814/Clara_Moura Soares 2017 Os Recheios do Paço do Ramalhã o Sintra Portugal a herança e o gosto artístico da rainha D. Carlota Joaquina de Bourbon in Co leções de Arte em Portugal e no Brasil nos séculos XIX e XX. Arte e seus lugares coleções em espaços reais Rio de Janeiro. 
Importa continuar no esclarecimento das fontes relativas à formação daquela colecção e do papel da soberana no campo do patronato cultural e artístico na corte de Portugal. 
III - O Palácio-Quinta do Ramalhão. Arquitectura, poder e cultura. Diversos testemunhos históricos.

\section{III.I - A Quinta do Ramalhão. Diversos testemunhos históricos}

A Quinta do Ramalhão, "situada numa eminência sobre as rochas piramidais de Sintra"73, "a cerca de vinte quilómetros de Lisboa", nas palavras de William Beckford (1760-1844), que ali fixara residência aquando da sua estada em Portugal, no Verão de $1787^{74}$, foi adquirida por D. Carlota, no ano de 1802, mediante escritura na qual a princesa se fez representar pelo 5 .은 Marquês de Marialva, Estribeiro-Mor, D. Diogo José Vito de Menezes Coutinho (1739-1803), “como Procurador por Comissão especial de Sua Alteza Real a Sereníssima Princeza do Brazil a Snr. a D. Carlota Joaquina"75.

Por aquele acto vinham, assim, à posse da soberana, por "auto de posse" lavrado "aos sinco dias do mês de Agosto" do referido ano, "duas quintas denominadas do Ramalhão [...] as quais constão de seo pateo de entrada e nella sua ermida, cazas por dois lados e tanque com suas figuras, e contiguas as sobred. $\underline{a}_{S}$ duas quintas que [...] a Estrada Real que vai p. $\underline{a}$ Cintra sendo ambas muradas de pedra, com seus pumares de [...] e carosso, arvores silvestres, oliveiras, tanques, ortas, jardim e caza de agua com seus aquedutos que vem de cima da Serra, terras de pão e todas as demais pertenças [...] que até aqui tem sido possuídas pela subrogante Donna Anna Joaquina Ignacia da Cunha, como por sua May Donna Maria da Encarnação Correa $[\ldots]^{\prime \prime 76}$.

Não é de estranhar a influência do 5. Marquês de Marialva neste negócio, tanto pela amizade que nutria por Beckford, testemunhada na obra literária do viajante, pelo que conhecia bem a propriedade onde o inglês estagiara por temporadas, bem como pela ligação muito próxima do Marquês Estribeiro-Mor à família real portuguesa. Nem é de estranhar, de igual modo, a eleição do lugar por D. Carlota Joaquina, cujo "temperamento ardente, apaixonado e

\footnotetext{
73 BECKFORD, William, Diário de William Beckford em Portugal e Espanha", introdução e notas de Boyd Alexander, traduzido por João Gaspar Simões, Empresa Nacional de Publicidade, 1957, p. 125.

${ }^{74}$ Beckford, na sua obra A Corte da Rainha D. Maria I, situa a sua chegada ao Ramalhão a 9 de Julho de 1787, acompanhando o Marquês de Marialva na sua deslocação a Sintra. In ob. cit., p. 70.

${ }^{75}$ ANTT, Casa das Rainhas, Maço 50, n.o 233.

${ }^{76}$ Idem,ibidem.
} 
certamente poético"77, segundo Oliveira Lima, fazia escolher lugares "graciosos e românticos" para as suas residências.

Na posse de D. Carlota Joaquina, a Quinta sofreria diversas obras e melhoramentos que se foram efectuando mesmo durante a ausência da família real no Brasil, de entre os quais se destacam a construção do portal nobre com as armas reais, a reparação da Capela, situada no pátio principal de entrada da Casa "seo pateo de entrada e nella sua ermida"78, conforme refere o auto de compra e de que nos dá conta o almoxarife João dos Santos, na sua correspondência com a então Princesa, para o Brasil.

A renovação arquitectónica a cargo de José da Costa e Silva (1747-1819), como revelou José Monterroso Teixeira, na sua tese de doutoramento sobre o arquitecto $^{79}$, visou então a criação de novos espaços, a qualificação de alguns pré-existentes, como por exemplo a "Ermida", sobre a qual há referências documentais específicas; o arco de acesso ao pátio principal, nobilitado com as armas reais; a decoração das salas com pinturas murais; a inscrição de monogramas da augusta proprietária, em diversos espaços, visando sinalizar a pertença da casa, bem como outros elementos de que nos falta maior detalhe, pese embora a tese acima mencionada.

O fiel almoxarife João dos Santos, na sua correspondência para a corte do Rio de Janeiro, de igual modo, nos elucida sobre diversas empreitadas levadas a efeito durante a longa ausência da proprietária, persistindo, no entanto, bastantes incógnitas relativamente aos artistas que ali terão trabalhado. Em 1809, João dos Santos refere a construção da cascata "[...] eu tenho feito algumas obras e não pequenas com os seos criados sem lhe fazer despezas. Fis a grande casquatta q. tem 100 e 8 palmos de frente meti a frente da parte da cavalharica e tudo fis de despeza sento e vinte mil r. a Casquata esta hua pessa linda despois o grande tanque por elle

\footnotetext{
77 LIMA, Oliveira, D. João VI 1808-1821, Edição ACD Editores, 200 Anos Portugal Brasil, s/data, p. 184.

${ }^{78}$ ANTT, Casa das Rainhas, Maço 50, n. 233.

79 TEIXEIRA, José Monterroso, José da Costa e Silva (1747-1819) e a receção do neoclassicismo em Portugal: a clivagem de discurso e a prática arquitetónica, tese de doutoramento. Repositório Institucional Camões, Universidade Autónoma de Lisboa, 2013, http://hdl.handle.net/11144/305, consulta online dia 18.02.19. O autor identifica importantes documentos na Biblioteca Nacional do Rio de Janeiro que testemunham a intervenção de José da Costa e Silva (1747-1819) nas obras então realizadas no Palácio-Quinta do Ramalhão após a compra da propriedade por D. Carlota Joaquina. A ampla correspondência enviada por João dos Santos, Almoxarife do Ramalhão, para D. Carlota Joaquina, então no Brasil, dá testemunho das obras a que ia procedendo, para completar, reabilitar e conservar, não só a casa, como a propriedade, in ANTT, Casa das Rainhas, Maço 241.
} 
p. a regar as Quintas e jardim" ${ }^{\prime 80}$; no ano seguinte justifica "em quanto a obras q. V.A. me argui não hé a sim só fis a casquata e não esta acabada a Cozinha, a Capella Mor da Irmida q. estava podre da humidade e isto tudo foi feito com o Mestre Pedro e Manel e o Ignacio pois V.A. bem sabe q. elles todos são officiais e não os devo ter parados" ${ }^{\prime 1}$.

Em Agosto de 1811, o almoxarife mencionava, de novo, arranjos agora no "tecto da Caza comprida", pois tinha caído, conforme escrevia, "pedaço do tecto da Caza comprida a onde dormirão as suas filhas" e, apesar dos consertos parcelares, tinha "cahido outro pedaço", levando-o então a decidir-se por "mandar deitar todo o tecto abaxo e fazelo de novo", concluindo "a sim levantei a Caza como as outras q. vem de trás mas p.a esta obra so fis de gasto duas moedas em duas dúzias de taboas p.a as canbotas pois tudo mais he da Caza, eu levo isto a Presença de V.a A. p. a se no cazo de hirem dizer a V.A. q eu faço obras Novas, V.A. saber quaes ellas são", justificando aquelas intervenções com o desígnio de "q se conserve a Sua Caza p. a se não perder e hera em decência pois aqui todos os Dias estão vindo Iglezes a vella, ella se conserva q. parece q. foi agora acabada. [...] ahinda q de V.A. não tenho recebido ordem alguma desde Maio de $1810[\ldots]^{\prime \prime 82}$.

A correspondência do almoxarife do Ramalhão era assim elucidativa das obras de conservação e os melhoramentos a que ia procedendo tanto na Casa, como na Quinta, não deixando de nos dar preciosas informações sobre a procura por parte de muitos viajantes ingleses que ali demandavam, nas suas deambulações por Sintra, o "paraíso glorioso" que Byron (1788-1824) ajudara a divulgar, no início do século XIX e que tanto encantara William Beckford, no final do século XVIII.

\section{III.II - O Paço do Ramalhão e a ocupação francesa}

O Paço do Ramalhão, pelo carácter da sua arquitectura, a revelar traços de influência italianizante, pela ligação da Casa com os jardins e a paisagem envolventes, pela ordem e organização dos espaços interiores, pela qualidade e diversidade dos móveis, pelos objectos de arte e de conforto de que dispunha, pelas pinturas a adornarem as salas ${ }^{83}$ e a reflectirem a

\footnotetext{
80 ANTT, Casa das Rainhas, Maço 241, n.7, 1809.

${ }^{81}$ ANTT, Casa das Rainhas, Maço 241, n. 18, 1810.

82 ANTT, Casa das Rainhas, Maço 241, n. 39, 1811.

83 Dirigindo-se à Junta das Reclamações, durante a ocupação francesa, em 1808, João dos Santos dá nota de que teriam sido cortados do Ramalhão e levados para Queluz "oleados" pintados. ANTT, Casa Real, Livro 2979.
} 
cultura, sofisticação e distinção da proprietária era, seguramente, uma das mais interessantes casas senhoriais, nas imediações da capital.

Não por acaso a escolheu Junot para aí dar um baile, "na primeira época da ocupação", como nos relata D. Pedro de Sousa Holstein (1781-1850) nas suas Memórias. Conta-nos o futuro conde, depois marquês e duque de Palmela que, gostando os "Franceses, como fazem sempre que podem, de ostentar festas sumptuosas, algumas delas nos palácios reais, como foi um baile que deu Junot no Ramalhão" ${ }^{84}$, tinham escolhido, para esse efeito, a casa da então Princesa do Brasil, o que é um testemunho eloquente do carácter singular e de excelência da mesma. Ideia confirmada, de igual modo, nas Memórias do marquês de Fronteira e de Alorna, D. José Trazimundo Mascarenhas (1802-1881), que nelas refere ter o General Junot principiado "também a dar as suas festas, diziam que brilhantíssimas", sendo "os seus jantares e bailes [...] frequentes, tanto no palacio do Quintella, na rua do Alecrim, como no palacio da Rainha Carlota, ao Ramalhão"85.

Não escapando ao olhar dos franceses invasores a riqueza dos interiores do Ramalhão, depressa delinearam o propósito de dali levarem os móveis para o Palácio Real de Queluz, onde Geoffrey de Saint Hilaire ${ }^{86}$, cunhado de Junot, acalentara o sonho de receber o Imperador dos franceses! Diversa documentação guardada no Arquivo da Torre do Tombo refere as Memórias apresentadas à "Junta das Reclamações" ${ }^{87}$, bem como as queixas expostas pelos almoxarifes dos Palácios Reais, de entre os quais o do Paço e Quinta do Ramalhão, que

${ }^{84}$ BONIFÁCIO, Maria de Fátima, transcrição, prefácio e edição, Memórias do Duque de Palmela, ed. D. Quixote, 2011, p. 115.

${ }^{85}$ BARRETO, D. José Trazimundo Mascarenhas, Memórias do Marquês de Fronteira e d'Alorna, ditadas por êle próprio em 1861, revistas e coordenadas por Ernesto Campos de Andrada, Parte Primeira e Segunda (1802 a 1824), Coimbra, Imprensa da Universidade, 1928, p. 40.

${ }^{86}$ Geoffrey de Saint Hilaire (1772-1844), era membro do Instituto de França, professor de História Natural e Comissário do Governo francês para a requisição de objectos de ciências e artes, tendo sido responsável pelo sequestro de muitos objectos pertencentes às colecções da coroa, e não só. A título de exemplo, no dia 31 de Agosto de 1808, apresentou-se na "Junta Literária da Impressão Régia" para aí recolher 544 chapas, pertencentes à Flora do Rio de Janeiro, da autoria de fr. José M. da Conceição Veloso, às quais se devem juntar espécies do Gabinete de História Natural da Ajuda, de que era director Domingos Vandelli, entre muitos outros objectos que sequestrou e de que chegava conhecimento à Junta das Reclamações.

87 Junta das Reclamações - Junta Administrativa dos Palácios e Bens anteriormente reservados para o serviço do Príncipe e da Família Real, criada por Decreto de Junot em 24 de Junho de 1808. A Junta era composta por três membros, os Desembargadores Francisco Duarte Coelho, António José Guião, Filipe Ferreira Araújo e Castro; e, como Secretário, João Lourenço de Andrade, e destinava-se a recolher as informações das queixas apresentadas relativas a prejuízos causados pelo exército francês, nas residências régias. 
contestavam os estragos que os invasores provocaram naquelas casas à sua guarda ${ }^{88}$. Assim, apesar de "Jeoffre"[sic], na "Memoria que deu à Junta das Reclamações", afirmar no "№1" que "o mobilier du Palais de Queluz a ete conserve integrallement; il a eté seulement arrangé d'une maniere plus moderne et l'on y a fait les augmentations jugées necessaires pour le rendre propre a y recevoir un Souverain...." 89 , assumia, no "№ "4, que "Ramaillon a eté demeublé et le mobilier a eté employé en totalité a Queluz"90.

Ora, o testemunho apresentado pelo Almoxarife do Ramalhão, em resposta à "Memoria de Jeoffre", era pouco abonatório da correcção com que os franceses invasores se tinham servido, a seu belo prazer, do mobiliário dos Palácios Reais, pois afirma "Do Ramalhão faltão pequenas couzas, mas tudo que erão armaçoens", os "oleados pintados", ficarão "estruídos [sic], não servem já p.a as Casas do Ramalhão"191. Na sua refutação à "Memoria", João dos Santos "reprova a ruina que soffreo a Armação do Ramalhão" e calcula o estrago, "segundo a conta dos Mestres que o fizerão", na "Importância dos Oleados do Palacio do Ramalhão 2.783\$000. Assignado Jacinto Xavier Mestre Pintor"92. Seguia-se a esta, outra nota do Almoxarife, datada de 14 de Setembro de 1808, na qual informava "Importão as Armações descriptas na Rellação que se entregou e aqui se lança o total de todas $=4.518 \$ 320$ r. que junta à outra conta asima faz a quantia de 7.301\$320r tudo o conteúdo esta em Queluz mas intaramente destruído que não pode já servir para o fim para que foi feito [... $]^{\prime \prime 3}$. Apesar da óbvia tentativa do almoxarife em tirar partido da situação, puxando pelo custo das reparações, podíamos extrair duas conclusões: a de que, durante a ocupação francesa, o mobiliário do Ramalhão tinha sido utlizado no Palácio de Queluz, e que o mesmo sofrera danos com as deslocações que obrigaram João dos Santos a consertos e reparações.

Nos inventários do MNAA encontra-se a referência a diversos fragmentos de pinturas que podem corresponder aqueles "oleados", representando flores e frutos, sendo mencionada, em duas, a existência de um "papagaio de cauda comprida" e, noutra, de uma "arara", com os números de inventário 442 Pint, 443 Pint, 444 Pint, 445 Pint, 446 Pint, 447 Pint, 448 Pint, 449 Pint, 450 Pint, sendo, em todas, referida a proveniência do Ramalhão, do espólio da Rainha D. Carlota Joaquina, bem como a compra das mesmas, pelo Estado português, em 1863, aos

\footnotetext{
${ }^{88}$ ANTT, Casa Real, AHMF, Livro 2979.

${ }^{89}$ ANTT, Casa Real, AHMF, Livro 2979, p. 15.

${ }^{90}$ ANTT, Casa Real, AHMF, Livro 2979, p. 15v.

${ }^{91}$ ANTT, Casa Real, AHMF, Livro 2979, p. 16.

92 São diversos os nomes apresentados na documentação consultada como autores de pinturas no Ramalhão, o que deverá ter ocorrido por empreitadas, em épocas distintas, o que mais à frente veremos.

93 ANTT, Casa Real, AHMF, Livro 2979, p. 17.
} 
herdeiros de Joaquim Rafael Rodrigues (Porto 1783-1864), a quem teriam pertencido e a sua autoria atribuída à "Escola Portuguesa do séc. XVIII, autor João Simão Navarro" ${ }^{94}$, pintor apresentado no Catálogo Provisório da Galeria Nacional de Pintura existente na Academia Real das Bellas de Lisboa, como "Espanhol. Vivia pelo meado do seculo XVII"95.

"Joaquim Raphael", pintor e escultor portuense, nomeado em junho de 1825, "Primeiro Pintor de Camara e Côrte", fora um dos académicos encarregues de avaliar a colecção de pintura, em tempo que antecede o leilão da Bemposta, pois é mencionado no documento no qual a rainha D. Maria II determina - " [...], aos Professores das Academias das Bellas Artes de Lisboa e Porto, Joaquim Raphael, e Francisco António da Silva Oeirense e a Luiz Pereira de Menezes para passarem a examinar e classificar os quadros do espolio de Sua Magestade Imperial a Senhora Dona Carlota Joaquina [...] existentes para venda em leilão no Paço Real da Bemposta $[\ldots]^{\prime \prime 96}$.

A formação artística de Joaquim Rafael fora feita na Escola da Porta do Olival, no Porto, fundada por Pillement, tendo aí sido discípulo de Domingos Francisco Vieira, e de seu filho, Francisco Vieira Portuense, pelos anos de 1802-1804, segundo o seu biógrafo H. C. Ferreira Lima $^{97}$. No final de 1824, depois de intensa actividade na cidade do Porto, Joaquim Rafael vem para Lisboa, sendo nomeado por Decreto de 20 de Junho de 1825, primeiro pintor da Corte e Câmara, lugar que se achava vago desde a morte "do insigne Francisco Vieira Portuense, em $1805^{\prime 98}$. Na corte lisboeta fora ainda encarregue da formação de "uma academia ou escola de desenho de Bellas Artes" 99 , anexa às obras do Palácio da Ajuda, que funcionou entre os anos de 1826 e 1833, com o nome de "Academia de S. Miguel"100, e que antecederia a instituição da Academia de Bellas Artes de Lisboa, em 1836.

\footnotetext{
${ }^{94}$ MNAA, Inventário da Pintura, Livro 4 e Livro de Aquisições 1850-1900.

95 Catálogo Provisório da Galeria Nacional de Pintura existente na Academia Real das Bellas de Lisboa, Lisboa, 1868, p. 36. Neste catálogo surgem três obras atribuídas a este artista e a referência a terem sido adquiridas aos herdeiros do pintor Joaquim Raphael, em 1863. No inventário do MNAA, anteriormente mencionado, são feitas referências a nove pinturas assim adquiridas.

${ }^{96}$ ANTT. Arquivo Histórico Ministério das Finanças, Caixa 7100. XX/Z/81 (12).

97 LIMA, Henrique de Campos Ferreira, Joaquim Rafael Pintor e Escultor Portuense, Imprensa da Universidade, Coimbra, 1923, p. 4.

98 Idem, ibidem, p. 27.

99 Idem, p. 30.

100 COSTA, Luiz Xavier, O Ensino das Belas-Artes nas Obras do Real Palácio da Ajuda (1802 a 1833), Academia Nacional de Belas Artes, Lisboa, 1936, p. 13.
} 
Luiz Xavier da Costa ${ }^{101}$ defendera aliás que o "ensino das belas-artes criado e mantido, por vezes com aspirações académicas, junto às obras da construção do Real Palácio da Ajuda", "e que lá se exerceu, [...] até ao encerramento das aludidas obras em 1833", em muito teria beneficiado a nova Academia Real de Bellas Artes, "pela qualidade e número dos professores e agregados"102, escolhidos de entre os que se formaram profissionalmente na "instituição didática", anexa ao Palácio da Ajuda.

Para a capela do palácio da Ajuda teria pintado, segundo o seu biografo, "cinco quadro, cujos assuntos" teriam sido "escolhido por D. João VI", e há ainda notícia de serem de sua autoria os bustos representando D. Maria I, D. João VI, D. Carlota Joaquina e D. Pedro IV, referidos pelo bibliotecário-mor da real biblioteca da Ajuda, José Manuel de Abreu e Lima, em Maio de 1833 e que se encontrariam em 1844, no "Gabinete de leitura de Suas Magestades na Real bibliotheca d'Ajuda [...] todos modelados em cera pelo hábil artista [...]". Assinava a nota o então bibliotecário régio, Alexandre Herculano (1810-1877) $)^{103}$.

Assim, a presença do pintor académico na corte e a sua ligação tanto à empreitada decorativa da Ajuda, como às instituições académicas de iniciativa régia, asseguravam-Ihe alguma proximidade aos príncipes e monarcas que aliás representou. A sua ligação à "Academia de $\mathrm{S}$. Miguel", durante o reinado de D. Miguel I (1828-1834), e os trabalhos de pintura decorativa, que executou, no Palácio, poderão ter favorecido o contacto com a rainha D. Carlota Joaquina.

Não sabemos, no entanto, de que modo os fragamentos de pintura que outrora pertenceram ao Ramalhão, Ihe teriam chegado à posse. Teria, enquanto académico avaliador, adquirido estas pinturas na sequência dos diversos leilões do espólio do Ramalhão? O que nos leva a

101 COSTA, Luiz Xavier, O Ensino das Belas-Artes nas Obras do Real Palácio da Ajuda (1802 a 1833), Academia Nacional de Belas Artes, Lisboa, 1936, p. 29.

102 Idem, ibidem, p. 12. De entre os artistas que exerceram a sua actividade artística nos programas iconográficos do Palácio Real da Ajuda destacaram-se, entre outros, Vieira Portuense que viria a morrer, prematuramente, em 1805, Domingos António Sequeira que seria afastado em 1809, por ordem do Inspector João Diogo de Barros, em consequência do processo contra si movido, fundamentado em acusações de jacobinismo e de colaboração com o invasor, acusações baseadas em testemunhos, entre outros, do pintor Manuel da Costa que Sequeira afastara das obras da Ajuda. Sequeira voltaria em 1818, aos serviços do Palácio em construção, dando pareceres sobre os novos trabalhos de pintura. Em 1823, enquanto "dilecto cooperador artístico do liberalismo constitucional que a reação de 1823 destruia", pediu licença dos seus cargos, saindo para Londres, alcançando posteriormente Roma, onde viria a morrer em 1837, sem mais voltar à sua pátria. O pintor Manuel da Costa, "hábil pintor e cenógrafo", depois de ter realizado diversas campanhas de pinturas decorativas nos Palácios de Belém, Vila Viçosa, Ajuda e Queluz, partiu para o Brasil, em 1811, onde participou em diversas empreitadas, entre as quais, na decoração do Teatro de S. João, do Rio de Janeiro, obra do arquitecto Costa e Silva. V. Xavier da Costa, na obra citada, 1936, p. 50.

${ }^{103}$ Idem, ibidem, pp. 28-29. 
questionar, igualmente, se seriam estas as pinturas cortadas, os "oleados", mencionadas na relação de 1808, relativamente às quais o Almoxarife João dos Santos reclamara os prejuízos causados pelos invasores franceses? Nada sabemos quanto à sua eventual reutilização no Palácio, o que poderia justificar a posterior venda, com o recheio do Ramalhão, em hasta pública. Se assim fosse, teriam sido executados em data anterior à partida da família real para o Brasil. O tipo de iconografia apresentada, de fauna e paisagens exóticas, faz-nos pensar na influência que exerceu a pintura de Jean Pillement no gosto artístico português e nos diversos discípulos que deixou, como tão bem estudou Agostinho Araújo na sua tese, já mencionada.

No âmbito das atribuições da Junta das Reclamações, e na sequência da ordem de João Diogo de Barros $^{104}$, João Lourenço de Andrade ${ }^{105}$, secretário daquela Junta, foi incumbido de fazer o levantamento e "examinar a Mobília de S. A. R. e de Particulares que está no Palácio de Queluz". Assim, em Setembro de 1808, apresenta a relação dos móveis do Ramalhão que se encontravam no Palácio Real de Queluz, "Relação do que achei em Queluz que pertence à Casa de S. A. R. A Princesa N. Sr.a sita na Quinta do Ramalhão"106, uma lista extensa e eloquente, compaginável com o "Inventário de toda a mobília que Existe no Real Paço do Ramalhão da Princeza N.S nr.a feito em Julho de $1807^{\prime 107}$, quanto à quantidade e diversidade de objectos de que dispunha o Ramalhão e que dali tinham sido desviados pelos franceses, aquando da ocupação das tropas napoleónicas pois que, para além dos "vasos de alabastro", dos "4 vasos de louça", dos "espelhos com bancas", da "Banca de Musaico", das "cadeiras de braços com assento cor d'ouro", "1 Canapé e 6 cadr.as de Cazemira escarlate", "6 Talhas de louça", "7 Caixas- huma com hu Plató de mármore, e 6 com pessas d'Alabastro", "36 Bambinellas, lá apareciam os "10 Oleados, tudo cortado", os "2 Painéis de fructas"108, "1 Dito do retrato de El Rey Luis 16", "36 paineis de vários tamanhos com molduras de pau Santo", "5 caixotes com painis", "12 paineis de frutas" ${ }^{109}$, entre muitos outros objectos, tanto de uso quotidiano, como de aparato.

\footnotetext{
104 João Diogo de Barros Leitão Carvalhosa (1757-1818), 1. Visconde de Santarém, por nomeação do Príncipe Regente D. João.

105 João Lourenço de Andrade, guarda-jóias e tapeçarias do Paço Real (1807-1823).

${ }^{106}$ ANTT, Casa Real, AHMF, Livro 2979, p. 12.

${ }^{107}$ ANTT, Casa das Rainhas, Livro 234. V. Bastos, Celina, "Percurso de Uma Pintura", in Luca Giordano. Êxtase de São Francisco, Museu Nacional de Arte Antiga, Secretaria de Estado da Cultura, Março, 2014. ${ }^{108}$ Referência que deve reportar-se às pinturas da autoria de Antonio de Pereda y Salgado (Vallad. 1599Madrid 1669), actualmente no MNAA - Natureza Morta com Cesto de Frutas, inv. 469 Pint. MNAA e Natureza Morta com empada, legumes e aprestos de cozinha, inv. 470 Pint. MNAA.

${ }^{109}$ ANTT, Casa Real, AHMF, Livro 2979, pp. 12 v., 13 e 13v. - "Relação do que achei em Queluz que pertence à casa de S.A.R. a Princesa N. a S.ra sita na Quinta do Ramalhão", assinada por João Lourenço de Andrade, por ordem de João Diogo de Barros, relativa à informação transmitida por João dos Santos,
} 
A "Banca de Musaico", mencionada na "Relação ${ }^{110}$, julgamos tratar-se da credência, actualmente no Palácio Nacional da Ajuda, com n.o inv. 1890, cuja execução é atribuída ao Laboratório de Pedras Duras e Mosaico, de Buen Retiro, de Madrid, fundado por Carlos III, na segunda metade do século XVIII. Sabe-se hoje que esta peça integra um conjunto de oito executadas pelo mesmo Laboratório, para a Casa Real espanhola, considerando aquele autor, o tampo de uma das mesas do Prado, como par do da Ajuda. Esta teria sido uma provável oferta de Carlos III a sua neta, a infanta D. Carlota Joaquina, quando da sua vinda para Portugal, em 1785, para casar com o infante D. João, sendo o exemplar da Ajuda o único "que não aparece no inventário feito por morte de Carlos III, em 1788, sendo todas as outras aí referidas", facto que corrobora a hipótese da peça àquela data já se encontrar em Portugal ${ }^{111}$.

$\mathrm{Na}$ "Relacção do que veio em 3 de Fevereiro de 1844 do Ramalhão p.a a Bemposta" encontramos no N. 3 referência a "Meza do mosaico e o caixote do muzeu de frutas", pelo que se depreende que teria estado na Bemposta a fim de ser leiloada. Teria sido adquirida por D. Maria II e posteriormente levada para o Palácio Real? É uma questão que fica em aberto.

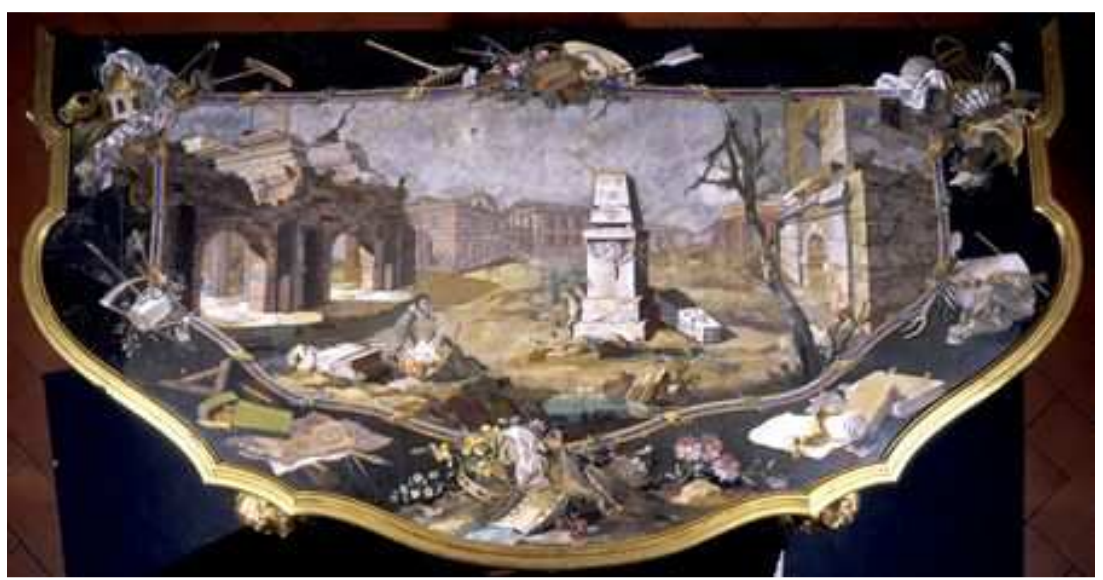

Credência, PNA, n. inv. 1890, Pormenor. Tampo representa uma paisagem arquitectónica com ruínas e figuras humanas. Ao centro da composição um obelisco com hieróglifos incisos, partido ao meio, estando a parte superior caída sobre terra, à direita do pedestal; Estrutura em bronze dourado e tampo com um trabalho elaborado em pedras duras, conhecido por "pintura de pedra". Execução - Laboratório de Pedras Duras e Mosaico, de Buen Retiro, Madrid ${ }^{112}$. Carlos III de Espanha, avô de D. Carlota Joaquina, assumira um papel destacado no financiamento das escavações de Herculano e Pompeia, a partir de 1738, desencadeando um interesse universal pelos achados daqueles sítios arqueológicos, que muito influenciaram a moda do "ruinismo" e das veduttas com representações alusivas às civilizações da antiguidade clássica.

Almoxarife do Ramalhão, em resposta à Memória de Jeoffre à Junta das Reclamações, a 15 de Setembro de 1808.

${ }^{110}$ ANTT, Casa Real, AHMF, Livro 2979, p. 12.

111 In http://www.matriznet.dgpc.pt/MatrizNet/Objectos/ObjectosConsultar.aspx?ldReg=990939. Palácio Nacional da Ajuda. N.o Inventário 1890; GONZALEZ-PALACIOS, Alvar, Las Colecciones Reales Espanolas de Mosaicos y Piedras Duras, Madrid, Museu Nacional del Prado, 2001, p. 182.

${ }^{112}$ Foto in http://www.matriznet.dgpc.pt/MatrizNet/Objectos/ObjectosConsultar.aspx?IdReg=990939. 


\section{III.III - O Palácio do Ramalhão. O teatro do quotidiano. A organização dos espaços interiores. Ordem e Simetria. Um "progresso na arte de viver"113. Estratificação social - organização espacial.}

"L'historien de l'art croit souvent qu'il n'a affaire qu'a des objects. En réalité, des relations organisent ces objets, leur donnent vie et signification : elles sont autant de choix théoriques fussent-ils inconscients - dont l'histoire et la critique demandent à être développés, faute de quoi les objets eux-mêmes risquent de se trouver incompris..."114

A simples observação dos levantamentos arquitectónicos ${ }^{115}$, conjugada com a informação documental ${ }^{116}$, permite-nos visualizar uma organização espacial na qual os corredores asseguravam uma distinção entre os espaços reservados à intimidade, os aposentos mais pequenos e numerosos, reflectindo a necessidade crescente de privacidade que o século XIX irá consagrar e os de maior dimensão, destinados às funções de representação ${ }^{117}$.

O índice do inventário de 1807 "Inventario de toda a Mobília que existe no Real Paço do Ramalhão da Princeza N. Snr. a feito em Julho de $1807^{\prime 118}$, através do qual observamos o tipo de mobiliário que cada divisão acomoda, é um instrumento fundamental para detectar, relativamente a cada espaço, a sua especialização funcional, e uma organização dos interiores que tende a ser racional e inteligível.

\footnotetext{
${ }^{113}$ CHAUNU, Pierre, A Civilização da Europa das Luzes, Volume II, Editorial Estampa, 1995, p. 116. O autor refere como o "palácio urbano do século XVIII revela, a quem souber observá-lo, um progresso na arte de viver" que tem a ver com uma organização dos espaços de um modo mais racional e funcional. ${ }^{114}$ DIDI-HUBERMANN, Georges, Devant le Temps, Les Éditions de Minuit, Paris, 2002, p. 59.

115 ANTT, Casa Real, Plantas, Almoxarifado do Ramalhão, n.os 314-315. V. TEIXEIRA, José Monterroso, José da Costa e Silva (1747-1819) e a receção do neoclassicismo em Portugal: a clivagem de discurso e a prática arquitetónica, tese de doutoramento. Repositório Institucional Camões, Universidade Autónoma de Lisboa, 2013. http://hdl.handle.net/11144/305, consulta dia 18.02.19.

${ }^{116}$ ANTT, Casa das Rainhas, Livro 234 (1807) e Casa Real, 387, Cx. 3703 (1829).

${ }^{117}$ Apud. Chaunu, Pierre, A Civilização da Europa das Luzes, volume II, Editorial Estampa, 1995, pp. 117118.

${ }^{118}$ ANTT, Casa das Rainhas, Livro 234 (1807). No Arquivo do Museu Imperial do Rio de Janeiro existe um importante documento que é esta mesma relação - "Inventário de toda a Mobília que existe no Real Paço do Ramalhão [...]", anotada à margem com as respostas dadas por João dos Santos sobre as alterações ocorridas após a saída da Família Real para o Brasil - "Declarações e João dos Santos, Almoxarife que foi do Paço e Quinta do Ramalhão [...]". Apesar de não estar datado, deve ser posterior a 1816 , correspondendo à passagem de testemunho de João dos Santos, aquando da sua substituição por António José da Silva, como Almoxarife daquele Paço.
} 
Começa aquele Inventário pelo "Andar Superior" e, neste, pela "Sala da Entrada", na qual se destaca, com o n. 1, "Huma pessa de Marfim q. representa o Palacio do Imperador da China na sua Capital com varias peças de alabastro", objecto de grandes dimensões e aparato que actualmente se encontra no Palácio Nacional de Sintra ${ }^{119}$. Ainda nesta divisão se referem duas cómodas de "Mogno com filetes e figuras de bronze doirado [...] com quatro Gavetas", e ainda "4 Armarios" que guardavam um conjunto diversificado de objectos, incluindo os dedicados a higiene pessoal e "toilette"120. Numa das gavetas da cómoda são mencionados "ferros de encrespar o cabelo", "agulhetas de tartaruga", "um maço de ganchos para o Cabelo", escovas e "1 D. a de limpar os dentes", enquanto um dos "Armários" continha "lacre, penas, papel fino de todas as qualidades", e outro "7 massos e baralhos de Cartas de Jogar Hamburguezas e 23 baralhos D.as Portuguezas"121, entre muitos outros objectos de uso quotidiano.

Seguem-se os aposentos íntimos, os quartos, compostos, numa ordem sequencial, por uma "ante Camara", com toucador, que antecede uma "Camara", que pode dispor de uma ou duas camas, a estas assoalhadas sucedendo um "Camarim", para o serviço de apoio.

Assim, no que respeita aos aposentos privados da então Princesa do Brasil, verificamos que eram compostos por uma ante-câmara ("Entre-camara n2"), com os seus variados armários e cómodas para o guarda-roupa, seguida de uma "Câmara da Princeza N. Snr.a no3", com a "Cama Imperial com armação de paninho arendado forrada de Nobreza azul claro", com a sua "Coberta de Casa bordada de raminhos de prata e seda de cor", não faltando o "Painel de cobre com moldura lavrada com o retábulo de Santo António"122, para a devoção privada, bem como os móveis para a higiene - o "Toucador guarnecido de paninho arrendado forrado de Nobreza azul claro" e o "bide estofado branco e doirado com bacia competente", a documentarem um progresso no que respeita à higiene íntima, que se pratica no quarto de dormir; seguia-se o "Camarim" N. 4, no qual encontramos referência à "menza de Jogo

\footnotetext{
119 Palácio Nacional de Sintra, inv. PNS 3005. Exemplar único no género, de acordo com o inventário daquele Palácio, trata-se de "Pagode", obra do século XVIII, da Dinastia Qing, reinado Quing Long, em marfim e madeira. Teria sido oferecido a D. Maria I, permaneceu no Ramalhão onde os inventariantes o foram encontrar, sendo posteriormente adquirido pela Rainha D. Maria II, no leilão da Bemposta, em 1850.

120 Nas "Declaraçoens [...]", Arquivo Museu Imperial Rio de Janeiro, I-POB-00.07. 1807, relativas à passagem de testemunho para o Almoxarife que o substituirá, João dos Santos refere terem ido os objectos, em falta, para o Brasil, nomeadamente a escova de limpar os dentes.

${ }^{121}$ ANTT, Casa das Rainhas, Livro 234.

122 Nas suas "Declaraçoens [...]" João dos Santos aquando da passagem de testemunho para o Almoxarife que o substituirá, argumenta, relativamente a este "Painel" que "Levarão-o os Francezes logo que entrarão no Paço consta do recibo q. Ihe fiz passar", pelo que, cerca de 1816/1817, o paradeiro desta obra era desconhecido. Arquivo Museu Imperial Rio de Janeiro, I-POB-00.07. 1807.
} 
inglesa forrada de Pn. o Verde" e a "caixa de Xarão com segunda de pau tendo dentro tentos de jogo de Voltarete e Isk com a Sifra da Princeza N. Snr. ${ }^{\text {a"123. }}$

A este conjunto de três aposentos, destinados à Princesa, sucedia uma "Segunda Câmara № 5" que dispunha de um "1 toucador", "1 Menza de jogo inglesa folheada", "1 Vidé doirado com bacia competente", uma "Camara Grande № 6"124, esta com "2 camas imperiais", (uma com guarnições amarelas e outra azul claro), "2 toucadores", "2 canapés" e "8 cadeiras", "2 vidés dourados com suas bacias", entre outros móveis, a "Camara nำ" e o "Camarim no 8". Dada a proximidade com o quarto da dona da casa, colocamos a hipótese de estas divisões se destinarem às infantas filhas. Os bidés, em número igual ao das camas, a testemunharem a individualização e privacidade das práticas de higiene.

Àqueles aposentos seguiam-se a "Caza da Pintura № 9" e a "Primeira, Segunda, Terceira e Quarta Salas", espaços que pelas dimensões e mobiliário alocado, seriam claramente, zonas de aparato e ostentação, destinadas à sociabilidade.

O quarto da Rainha, neste caso D. Maria I, surgia na sequência das divisões de aparato e replicava, em organização funcional, o da então Princesa do Brasil. Era o mesmo composto de "Ant Camara nํ14", com a "Caixa de toucador de xarão com seus pés"125, "1 Banco com sua almofada em tudo irmã da armação com dois travesseiros e coberta de xita de riscas encarnada e amarelas", seguida da "Camara № 15 P.a a Rainha N. Snrā" com uma "Cama Imperial de pau setim com armação de paninho branco arrendado de riscas e raminhos forrada de paninho azul ferrete", uma "Cadeira de braços doirada furada com coxim

\footnotetext{
123 Julgamos ser a Caixa de Jogo, inv. PNQ 137/A1, China c. 1800, "madeira de teca, madeira lacada. Contêm 7 pequenas caixas de teca lacada para cartas (inexistentes) e fichas de madrepérola [...]. Monograma com as iniciais PC (Princesa Carlota?) e as Armas Reais". Palácio Nacional de Queluz. http://www.matriznet.dgpc.pt/MatrizNet/Objectos/ObjectosConsultar.aspx?ldReg=999602. Consulta online Abril 2019.

${ }^{124}$ Seria esta a "Caza comprida a onde [sic] dormirão as suas filhas" que João dos Santos refere na carta, datada de Agosto de 1811, para D. Carlota Joaquina? In ANTT, Casa das Rainhas, Maço 241, n. 39, 1811. 125 Do nosso ponto de vista será o Toucador-escrivaninha inv. PNQ 937/1 de madeira de teca e laca, semicircular com semelhanças com a caixa de jogo marcada com as iniciais de D. Carlota, inv. PNQ 137/A1. De referir que, segundo ficha de inventário do Palácio de Queluz, "um toucador com decoração muito semelhante, datado de finais do século XVIII e considerado como tratando-se de espelho de toucador com uma forma similar ao da colecção do Palácio datado de c. de 1800, foram vendidos em leilão pela Sotheby's em Londres", o que condiz com o facto de, no Inventário de 1807, serem referidas duas "caixa(s) de toucador de xarão com os seus pés", de idênticas características. Consulta online, www.matriznet.dgpc.pt. Palácio Nacional de Queluz. Abril de 2019.
} 
amarelo"126, um "Vidé doirado com competente bacia", a denotar, tal como nos outros quartos, a salvaguarda da privacidade e a intimidade das práticas de higiene. Aquelas câmaras sucedendo um "Camarim №16 P.a a Rainha N. Snr. ㅁ", com a "Cama de ferro com armação de xita guarnecida de franja de linha branca maçanetas de bronze doirado", claramente para o serviço de apoio à soberana. Seguiam-se mais duas "Camaras", a "№s 17", com "1 cama Imperial com balaústres doirados armação de xita da Índia", "1 Caixa de xarão p.a toucador com seus pés"127, "1 canapé", "6 cadeiras de mogno", e a "№18", onde para além de "1 cama Imperial" em tudo idêntica à do aposento anterior, dispunha de "1 carteira de pau setim com embutidos de varias cores, e em cima huma Instante p. livros", "as 6 cadeiras" e "1 Canapé em tudo Irmão das cadeiras", "1 Caixa de xarão p.a toucador", "1 vidé doirado com bacia competente". Seriam para a Princesa do Brasil viúva, D. Maria Francisca Benedita, estes últimos compartimentos? A referência a estantes para livros assim faz supor, uma vez que conhecemos o papel da leitura no quotidiano da Princesa viúva, atestado pelo catálogo da sua Livraria, na Biblioteca da Ajuda. No entanto, nenhuma informação tal confirma, pois no inventário apenas relativamente a dois "quartos"128, são mencionadas destinatárias, isto é, a "Camara da Princeza N.Snr. ${ }^{2}$ " e a "Camara p.a a Rainha N. Snr. $\underline{\text { " }}$.

Este inventário ${ }^{129}$ parece apontar para um destino, quase que exclusivo, de residentes femininas, sendo eventualmente esporádica a permanência de elementos masculinos, como sabemos, por testemunhos epistolares, seria o caso de o Príncipe Regente, aí pernoitar. Assim o parece confirmar a carta, datada da "Bemposta", do dia "12 de Setembro de 1805", dirigida a D. Carlota Joaquina que naquele momento se encontrava no Ramalhão, na qual D. João responde, a eventual convite que a princesa lhe dirigira, despedindo-se em termos afectuosos — "a Deos meu amor ate Sabado a noite q. fico com muito gosto [...] esperando o do dia para ser teu Hospede que nisso te da huma prova este que preza ser Esposo que mto te ama"130.

\footnotetext{
126 Julgamos que seja a "cadeira furada" do Palácio Nacional de Queluz, inv. 123/1 ou a 123/2, qualquer uma delas transferida do Palácio Nacional de Sintra, onde se encontravam.

127 São mencionadas no Inventário estas duas ditas Caixas de toucador de xarão o que parece confirmar a hipótese de uma se encontrar no Palácio Nacional de Queluz e outra ter sido a vendida em leilão da Sotheby's, em Londres.

128 Quarto, enquanto conjunto de aposentos funcionais reservados a uma mesma pessoa.V. MADUREIRA, Nuno Luís, Cidade: Espaço e Quotidiano. Lisboa 1740-1830, Livros Horizonte, Lisboa, 1992, p. 121.

${ }^{129}$ ANTT, Casa das Rainhas, Livro 234, "Inventário de toda a Mobília que existe no Real Paço do Ramalhão da Princeza N. Snr. a feito em Julho de 1807".

130 Museu Imperial do Rio de Janeiro, Arquivo, coleç̧ão POB, http://200.159.250.2:10358/handle/acervo/978. 07-I-POB-17.08.1805-JVI.P.d1-3 [d03 p01], 08- I-POB17.08.1805-JVI.P.d1-3 [d03 p02]. Consulta online, 20 de Maio de 2019.
} 
Talvez por ser episódica a estadia do então Príncipe Regente no Paço do Ramalhão, no qual ficaria apenas com o "Hóspede", não detectamos um espaço que the pudesse ser reservado, em exclusivo.
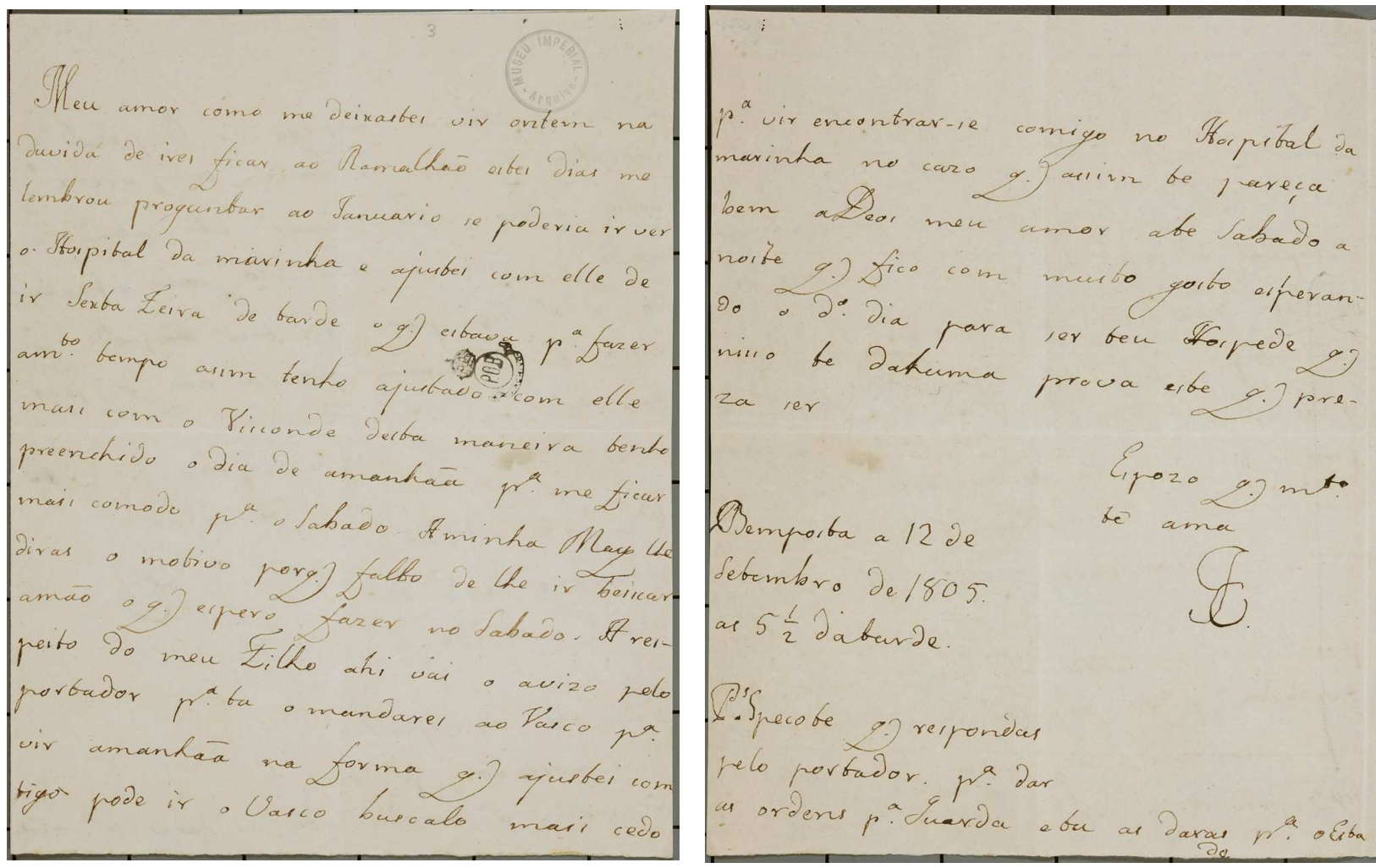

Carta de D. João VI a D. Carlota Joaquina, Setembro 1805, na qual comunica a sua intenção de pernoitar no Ramalhão. Ms. Arquivo do Museu Imperial do Rio de Janeiro.

De igual modo, por não se denotar no Ramalhão a presença de um guarda-roupa, para a Rainha D. Maria I, com a extensão do existente no Palácio de Queluz ${ }^{131}$, leva-nos a concluir a ser a mesma senhora, aqui, eventualmente, uma "hóspede" idealizada, uma vez que estagiava habitualmente no Palácio Real de Sintra.

A este conjunto de Câmaras sucedia a "Caza dos Armarios № 19" que, tal como o nome indica, dispunha de armários, oito, guardando o "Armario № 1" serviços de loiça, tais como "1 Serviço de louça de França doirada com a sifra de S.A.R. a Princeza N.Snr. ${ }^{\prime \prime}$, contemplado, entre outras peças, "16 duzias de pratos de guardanapo"; "1 Serviço de loiça Ingleza doirada e Pintada de Amarelo com a sifra da Princeza N. Snr.a”132, entre outros; o "Armário № 2"

131 MADUREIRA, Nuno Luís, Cidade: Espaço e Quotidiano. Lisboa 1740-1830, Livros Horizonte, Lisboa, 1992, pp. 118-120, citando PIRES, António Caldeira, História do Palácio de Queluz, Vol. II, Coimbra, Imprensa da Universidade, 1926, pp. 295 e ss. BA 126/119 N-21.

${ }^{132}$ No Palácio Nacional da Ajuda guarda-se parte de dois serviços de porcelana provenientes do Ramalhão, ambos com decoração a amarelo e ouro, com o monograma da Princesa D. Carlota - CJPB, de fabrico inglês, um de Coughley (Coalport) e outro de Worcester. No Arquivo do Museu imperial de 
guardava os objectos em vidro; o "Armário №3" guardava "castiçais e serpentinas em bronze doirado"; o "Armário № 4" acondicionava a "Roupa de Linho"; o "Armario № 5", o "1 Serviço de loiça da Índia ord.ra" e "outro serviço da mesma loiça com deferente Padrão"; o "Armario N. ㅇ" guardava o "plató de Alabastro com cercadura de cores do mesmo alabastro consta de 20 peças"; o "Armário N.7" guardava "122 Lençois de Holanda", entre outras peças do mesmo tecido; e o "Armário da Prata", destinava-se a guardar os faqueiros e restantes objectos naquele metal. Este espaço, exclusivamente afecto a arrumação, antecedia, por fim, a “Caza de Jantar № 20", último na sequência do andar nobre. Nela, destacam-se "24 cortinas e 12 banbinelas [...]", pelo que deveria dispor doze janelas, sendo mencionadas " 12 cadeiras de Mogno com assentos e costas de setim azul claro lavrado [...]", "8 aparadores" e "4 Collunas cada huma com sua bacia grande da India em sima, cujas estão nos 4 cantos da mesma Caza", não existindo, no entanto, nenhuma alusão a mesa de refeições, neste inventário.

Seria, sem dúvida, a sala "lanterna" que William Beckford (1760-1844) refere no seu Diário, por, escrevia, "não ter menos de doze janelas e portas envidraçadas e de largas dimensões" 133 . Julgamos que, quando da presença do inglês, não deveria ainda apresentar as pinturas murais que a viriam a caracterizar e distinguir, pois nunca nela o escritor refere qualquer tipo de ornamentação. O mesmo não sucedendo quando descreve a casa do Marquês de Marialva, ali destacando o pavilhão "desenhado por Pillement", representando "um caramanchel formado pelos ramos entrelaçados de fantásticas arvores indianas, deixando entrever a trechos o azul estivo do ceu"134.

A questão da autoria destas pinturas tem sido objecto de diversas teses, sendo certo que o espírito que presidiu à decoração daquela sala se filia na estética difundida pelo mestre lionês, apesar de, segundo Agostinho Araujo, a paleta utilizada nas pinturas murais do Ramalhão diferir da de Jean Pillement (1728-1805), o mesmo ajudara a difundir um gosto por decorações pictóricas que privilegiavam a representação de floras e faunas tropicais que, de algum modo, se poderia relacionar com as particularidades dos encomendadores, na sua relação com o "novo mundo".

Petrópolis existe documentação relativa a compras efectuadas por D. Carlota Joaquina, nomeadamente de um serviço de loiça inglesa, em 1804, para o Ramalhão. Cota: I-POB-21.07.1814 - CJ. P. rb.

${ }^{133}$ BECKFORD, William, A Côrte da Rainha D. Maria I, Livraria Editora Tavares Cardoso § Irmão, Lisboa, 1901, p. 108.

${ }^{134}$ Idem, ibidem, p. 65. 
A adaptação de Pillement ao terreno cultural português ${ }^{135}$ tivera como contraponto a assimilação da sua técnica por uma plêiade de pintores que ora frequentaram a sua escola no Porto, ora trabalharam debaixo da influência do mestre, nas diversas empreitadas em que estivera envolvido, nas residências de uma elite de corte. Tal foi o caso de Joaquim Rafael Rodrigues (Porto 1783-1864), a cujos herdeiros o estado português comprará pinturas que anteriormente haviam pertencido à Casa do Ramalhão.

Presumimos que a campanha decorativa levada a efeito após a compra da propriedade por $D$. Carlota Joaquina, incluísse, para além da remodelação arquitectónica, a realização das mencionadas pinturas murais, uma vez que nas diversas intervenções que Costa e Silva protagoniza, se fez sempre acompanhar de pintores decoradores, de entre os quais se salientou Manuel da Costa (c. 1755-Rio de Janeiro 1820), e naquela fase há muito que Pillement já não se encontrava em Portugal ${ }^{136}$.

José Monterroso Teixeira atribui a autoria dos frescos a "um pintor empregado no Arsenal do Exército, de origem italiana", que teria recebido "51 $200 \$ 00$ réis pelo seu trabalho", conforme documento que cita, localizado na Biblioteca Nacional do Rio de Janeiro, relativo à pintura da casa de jantar, datado de 1805 e assinado por "O Contramestre da Off.a de Pintores do Arsenal do Exercito Domingos Belgazzi [Prelgazzi ?]"137. No entanto, relativamente a este artista, não encontramos mais nenhuma referência, pelo que continuamos a considerar incerta a autoria daquelas pinturas, a exigir mais aprofundado estudo, nomeadamente comparativo, com exemplos existentes em outras residências aristocráticas da corte lisboeta.

Estratificação social. Organização espacial. Ainda no piso superior, mas numa zona diferenciada, encontravam-se os aposentos destinados às damas, cujo acesso se fazia pela "Caza da Espera da Entrada Superior №21", à qual sucedia a "Saleta da Entrada Enfrior p.a os quartos de Sima № 22" e uma sequência de seis "quarto das Damas № 23, 24, 25, 26, 27 e 28 " e por fim a "Ermida № 29".

135 V- ARAÚJO, Agostinho, "Experiência da Natureza e Sensibilidade Pré-Romântica em Portugal. Temas de Pintura e seu consumo (1780-1825", Dissertação de Doutoramento em História da Arte, Fac. Letras do Porto, 1991. Consulta online. http://hdl.handle.net/10216/13668. Janeiro 2019.

${ }^{136}$ Francisco Costa na sua obra Beckford em Sintra no Verão de 1787 - História da Quinta e Palácio do Ramalhão, de 1982, defende que aquelas pinturas "devem ser posteriores a 1821, porque nelas predomina a flora tropical que a rainha só conheceu de perto durante a sua permanência no Brasil". Obra citada, p. 80. O que é contestável, pois já Pillement, nos períodos que exerceu a sua arte em Portugal, entre 1780-1786, ajudara a difundir um gosto pelas paisagens exóticas.

137 TEIXEIRA, José Monterroso, José da Costa e Silva (1747-1819) e a receção do neoclassicismo em Portugal: a clivagem de discurso e a prática arquitetónica, Tese de Doutoramento, Repositório Institucional Camões, Universidade Autónoma de Lisboa, 2013, pp. 345-346. http://hdl.handle.net/11144/305. Consulta Janeiro 2019. 
No "Andar de baixo" localizavam-se as zonas de serviço, tais como as zonas de engomar, no "Quarto №5", com "2 Bancas de engomar de vinhático"; zonas de arrumos de diversa ordem na "Caza da Fazenda", na qual encontramos a referência a "12 cobertores de pano fino escarlate", "200 de papa Inglezes finos", "64 ditos mais ordinários", "24 cobertas de chita para as camas"e "25 armações de dita para as ditas dos quartos dos Camaristas, Damas e Açafatas", "2 cobertores de baetinha de seda p. a as camas dos Senhores". Os "Quartos dos Camaristas", ocupavam a zona que ia do "Quarto № 24" ao "Quarto 28" isto é, cinco quartos, todos com o mesmo tipo de mobiliário - a sua "cama de ferro", as suas "2 bancas", "1 cadeira furada", "1 bacia e jarro de pó de pedra", "1 Dita para fazer a barba", "1 escrivaninha de bronze com os seus pertences", "1 espelho" e " 1 castiçal de latão com candeeiro pegado". Existia ainda uma "Caza de Jogo para os Camaristas", uma "Caza da Copa N.e 30", uma "Caza № 31" que guardava os objectos em cobre, ferro, folha e pau, uma "Caza de Bilhar e Caxe" [sic] e por fim a "Cozinha", com todos os seus adereços.

Pelo exposto, na distribuição das funções pelos espaços, verificamos vários tipos de clivagens - uma, que se estabelece na oposição entre o piso nobre, mais elevado e o piso térreo, adstrito aos criados e ao serviço, configurando uma estratificação em altura; outra, através da distribuição dos quartos, no pavimento superior, com a arquitectura interior e o mobiliário a determinar a maior, ou menor, dignidade na hierarquia social, do destinatário, configurando uma estratificação horizontal ${ }^{138}$, que distinguia os aposentos dos "senhores", dos das "damas" que os serviam. Uma outra oposição verifica-se na separação, entre os aposentos do pessoal feminino, a ocupar áreas distintas no piso superior, com entrada diferenciada, e os destinados ao pessoal masculino, a ocupar o piso inferior, em áreas anexas às copas e cozinha. A organização arquitectónica enquanto reflexo da ordem e estratificação social.

No piso nobre da Casa, no corpo longo virado a poente, um corredor, paralelo aos quartos, permitia reservar o acesso às zonas de carácter privado, definindo fronteiras destinadas a separar a intimidade, da sociabilidade, para a qual estavam destinadas diversas salas colocadas em enfiamento, situadas entre a zona privada da então Princesa do Brasil e os aposentos destinados à Rainha. Ali se encontravam a "Caza da Pintura no 9" e as "Pr.a Salla № 10, Seg.da Salla № 11, Terceira Salla № 12 e Quarta Salla № 13", que consideramos como espaços de carácter mais público e de aparato e que devem corresponder à "enfiada de aposentos,

${ }^{138}$ V. a este propósito, MADUREIRA, Nuno Luís, Cidade: Espaço e Quotidiano, Lisboa 1740-1830, Livros Horizonte, 1992, pp. 117-120. 
espaçosos e arejados" que impressionara Beckford na sua primeira visita ao Ramalhão, conforme anotara em 7 de Julho, no seu Diário.

Julgamos que seria para as quatro salas que se destinariam as "Alcatifas", mencionadas por João dos Santos na carta para a então Princesa do Brasil, datada de 24 de Março de 1811, que o mesmo queria importar de Inglaterra, e na qual informava custarem "900\$000 reys p. a as quatro Sallas"139 pois, segundo ele, "os Panos dellas não ficarão capazes eu os tenho aproveitado todos nas outras Cazas e tudo esta de novo"140. Porque as ordens que recebesse não fossem favoráveis àquela despesa, justifica-se "Vejo que me dis q. não mande vir as Alcatifas nuca o avia fazer sem ordem de V.A. pois é do meu dever dar parte do Estado das couzas, eu se lembrei a V.A. as Alcatifas hera em rezão de ter destruído os Panos os Francezes quando os troserão para Queluz, mas eu já tenho arranjado os quartos todos, esta pinta [sic] de novo pelo Manoel da S. a a sim como todo o Paço; e os trastes estão também arranjados e mto bonitos ahinda estão em caxotados"141.

Nestas salas de aparato, as "salas nobres"142, ou "salas de respeito" de que falam as "relações"143, encontramos, para cada uma, o seu "lustre grande de vidro lapidado", as "serpentinas de vidro lapidado com guarniçoens de bronze doirado de três lumes cada hua em mangas de vidro", ou as "serpentinas de Cristal de trez lumes", os conjuntos de espelhos e tremós, o móvel por excelência "ostentatório, luxuoso e supérfluo"144, as cadeiras e canapés estofados, quase sempre apresentados em número par. Como escreve Carlos Franco "Os bens móveis dispõem-se aos pares, uma regra decorativa sempre, constituindo-se séries de objectos idênticos nas formas, tons e materiais que se replicam por aquela ordem. O par, neste caso, não se afigura como desprestigiante nem quebra a ideia de originalidade, antes pelo contrário. Aquele permanece singular, na medida em que não é produzido em massa, logo, pode ser-lhe

139 No leilão da Bemposta foram vendidos "quatro tapetes grandes das salas nobres", referência em ANTT, Casa Real, Cx. 6523, "Relação dos trastes e mais objectos q. ainda existem no Ramalhão e no Palacio de Cintra ao serviço de S. M. F. pertencentes ou não pertencentes à Herança".

${ }^{140}$ ANTT, Casa das Rainhas, Maço 241, n.o 31.

${ }^{141}$ ANTT, Casa das Rainhas, Maço 241, n.o 46, 1812. A referência à destruição dos "panos", por parte do almoxarife do Ramalhão deve, neste caso, corresponder aos estragos vários praticados pelos invasores franceses, quer de tapetes, quer de cortinados.

${ }^{142}$ ANTT, Casa Real, Cx. 6523.

$143 \mathrm{Em}$ documento correspondente à passagem de testemunho de João dos Santos, para o Almoxarife que o substitui, (c. de 1816) estas quatro salas são denominadas "Sallas de Respeito". Museu Imperial do Rio de Janeiro, Arquivo, I-POB-00.07.1807.

144 MADUREIRA, Nuno Luís, Cidade: Espaço e Quotidiano. Lisboa 1740-1830, Livros Horizonte, Lisboa, 1992, p. 225. 
acrescido o prestígio inerente a uma maior quantidade e a uma opção decorativa que privilegia a multiplicação de bens"145.

As salas ocupando áreas maiores do que as "camaras", com sequências de móveis de assento, na sua vastidão, prefiguravam espaços de representação, nelas se destacando a profusão de têxteis - das cortinas, às bambinelas e estofos dos assentos - que, a par com os conjuntos de móveis, cumpriam "um papel fundamental, quando nos referimos às casas das elites" pois, segundo Carlos Franco, eram "um bem luxuoso", de elevado preço, sinal de distinção, "pela intuição de que desde a roupa branca às sedas e damascos, todos indiciavam o nível económico, as exigências e o gosto existente numa residência"146. Através dos inventários podemos apreciar a diversidade dos estofos dos assentos, de cores e texturas acertadas com os tecidos das bambinelas e cortinados, com galões, passamanarias e guarnições, a completarem a decoração, conferindo aos espaços simultaneamente uma atmosfera de conforto e sumptuosidade. As pinturas murais, "pompeianas", a evocar os frescos de Pompeia e Herculano, ou os "oleados [...] pregados nas salas" que constam dos inventários ${ }^{147}$, ou a colecção de pintura, demonstrando o sentido estético e a sensibilidade artística da proprietária. O efeito cenográfico era acentuado pelos jogos de luz proveniente quer das "serpentinas de vidro lapidado com guarniçoens de bronze doirado", quer dos lustres grandes de vidro lapidado, e do seu reflexo nos espelhos e nas superfícies brancas e doiradas das pedras que cobriam cómodas e tremós. Os espelhos a criarem a ilusão de um espaço duplicado.

A ligação ao exterior, através das grandes janelas, ou vãos, por onde entrava a luminosidade e o som da água a cair nos tanques adjacentes, contribuía seguramente para a criação de uma sensação de bem-estar, que já Beckford descrevia - "os transparentes jorros d'agua, que em baixo repuxam d'um tanque, alimentado continuamente pelas nascentes da rocha viva", ou as "harmonias dos instrumentos de vento, que tocavam a distancia, em um laranjal" que ouvia do seu "renovado pavilhão"148 e the alimentavam sentimentos de melancolia, tão cara à sensibilidade pré-romântica e romântica, numa atração sentimental pelos efeitos da natureza.

145 FRANCO, Carlos, Casas das Elites de Lisboa. Objetos, interiores e vivências 1750-1830. Scribe, 2015, p. 283.

${ }^{146}$ Idem, ibidem, p. 121.

${ }^{147}$ ANTT, Casa Real, Cx. 6523.

${ }^{148}$ BECKFORD, William, A Côrte da Rainha D. Maria I, Livraria Editora Tavares Cardoso § Irmão, Lisboa 1901, pp. 94 e 77. 
Helder Carita refere a tipologia de "palácio-pavilhão", a qual se distinguia por uma forte e "convidativa relação com os exteriores e os jardins", na qual a "simplicidade do desenho das fachadas", se contrapunha "à escala dos interiores", nos quais se desenvolviam sofisticados programas decorativos, definição essa que o autor chega a partir de uma análise comparativa de três casos - o Palácio de Seteais, a Quinta de S. Sebastião em Sintra, e o palácio do 2.으 Marquês de Pombal, em Queluz - "nos quais emerge um grupo de características" que pela sua recorrência e evidentes afinidades se instituem como uma tipologia arquitectónica de casa senhorial"149, limitando-se, no entanto, segundo o autor, o "caracter requintado e profundamente cosmopolita desta tipologia", em Portugal, "a escassos exemplares sendo expressão de uma alta aristocracia e de uma cultura de elite [...]"150. Julgamos ser possível estabelecer pontos de encontro entre esta tipologia arquitectónica e o Paço do Ramalhão, entre a simplicidade do desenho arquitectónico exterior e a profusa decoração dos interiores, sendo em todos eles presente o desenho de Costa e Silva, conforme analisou José Monterroso Teixeira, na sua tese de doutoramento ${ }^{151}$.

Continuando a acompanhar o inventário de 1807, verificamos que a "Pr.a Salla N.10", com as suas "18 Cortinas e 9 banbinelas de paninho arrendado de Listras guarnição oiro e preto", teria 9 janelas, ou vãos, e "1 tremó de Mogno com figuras de bronze doirado e pedra branca com seu espelho grd.e em sima também de mogno e guarniçoens de pau setim com filetes doirados", "os 2 vasos de Saxonia com filetes doirados", "2 urnas pequenas de Alabastro", "10 cadeiras doiradas com coxins amarelos e capas de festão branco", o "lustre grande de vidros lapidados com guarnição de bronze doirado"; a "Seg.da Salla N.a 11", com "28 Cortinas e 14 banbinelas de paninho arrendado em xadres com guarnição de trancelim de prata e retros [...]", teria então 14 janelas, e "2 Tremós de Mogno com figuras bronziadas e guarniçoens de bronze doirado pedra branca em sima da qual Espelho grde de moldura de Mogno guarnecido de bronze doirado e em sima da mesma pedra de cada hum dos ditos tremós um Grande Vazo de Loiça da Saxonia [...]" e "4 Cantoneiras" igualmente com guarnições doiradas e pedra branca em cima, "4 cadeiras de braços" e "8 D.as sem braços" todas "estofadas de seda

149 CARITA, Helder, A Casa Senhorial em Portugal. Modelos, Tipologias, Programas Interiores e Equipamento, Leya, Dezembro 2015, p. 479.

150 CARITA, Helder, 2015, p. 480.

151 TEIXEIRA, José Monterroso, José da Costa e Silva (1747-1819) e a receção do neoclassicismo em Portugal: a clivagem de discurso e a prática arquitetónica, Tese de Doutoramento, Repositório Institucional Camões, Universidade Autónoma de Lisboa, 2013, Repositório Institucional Camões, Universidade Autónoma de Lisboa, 2013, http://hdl.handle.net/11144/305. Sobre a intervenção de Costa e Silva em diversas residências nobres ver Capítulo V. "O Ciclo da Arquitectura residencial de Aparato", pp. 269-346, consulta online, Janeiro 2019. 
lavrada e galoens azul claro [...]". O mobiliário das duas Salas seguintes repetia, em tipologia de mobiliário, as duas primeiras, tendo a Sala N. 12, vinte e oito cortinas e catorze bambinelas e a Sala N.o 13, dezoito "cortinas e nove bambinelas de paninho arendado de listras guarnição verde e oiro", com as suas "10 cadeiras de mogno estofado de seda verde [...]", pelo que, esta última, deveria ocupar uma área inferior.

A simples exposição do inventário, nesta sequência de espaços com os seus móveis e os coloridos estofos, evoca-nos a descrição que Beckford faz da sua "vila" em Sintra, quando habitou o Ramalhão, e do "labyrintho de salões encantados", nos quais "grandes e polidos espelhos multiplica[va]m" a "profusão de cortinados" e "os diferentes grupos de objectos reflectidos por todos os lados nas mais inesperadas direcções"152. Este devia ser o ambiente sofisticado e luxuoso que se vivenciava no Paço do Ramalhão que fora refúgio de um inglês diletante e rico, e depois lugar de abrigo e exílio de uma infanta de Espanha que foi Rainha de Portugal e Imperatriz do Brasil.

\section{III.IV - Ordem e simetria}

Podemos considerar que o ciclo decorativo utilizado no Paço do Ramalhão, enquanto Casa da Princesa do Brasil e depois refúgio da Imperatriz-Rainha, se enquadra na defesa da "boa e justa symetria"153, como defendia de Costa e Silva, tão cara à ordem clássica. "A regra de simetria da arquitectura clássica"154 que, no interior, se confirma na disposição dos móveis, quase sempre, em número par, nomeadamente no que às cadeiras, às cantoneiras e às cómodas, respeita. $A$ utilização de conjuntos, e a disposição simétrica, com a repetição de cenários que lhe está inerente ${ }^{155}$, parecem traduzir o espírito de um classicismo revisitado, agora pelo estilo Império, que nos é anunciado pelo tipo de decoração dos móveis, quase sempre com os seus bronzes doirados, tais como o "tremó de mogno com figuras de bronze doirado e pedra branca com seu espelho Grd.em sima", de que encontramos referências para as salas N.os 10, 11, 12 e 13.

152 BECKFORD, William, A Côrte da Rainha D. Maria I, Livraria Editora Tavares Cardoso § Irmão, Lisboa, 1901, p. 95

153 CARVALHO, Ayres, Os Três Arquitectos da Ajuda. Do "Rocaille" ao Neoclássico. Academia Nacional de Belas-Artes, Lisboa, 1979, p. 122, nota referente a parecer de Costa e Silva sobre a Praça do Comércio, datado de 12 de Fevereiro de 1803.

${ }^{154}$ CHAUNU, Pierre, A Civilização da Europa das Luzes, Volume II, Editorial Estampa, 1995, p. 112.

155 FRANCO, Carlos, Casas das Elites de Lisboa. Objetos, interiores e vivências 1750-1830, Scribe, 2015, p. 283. 
Os materiais utilizados são as madeiras exóticas e preciosas, tais como o mogno, o pau-cetim, e o pau-santo, nas quais são aplicadas ferragens de bronze dourado, as cómodas e cantoneiras, dispondo de tampos de pedra mármore, cuja cor varia entre o "branco e a pedra preta", ou os "sal pimenta". Nas camas as referências são, quase sempre, de "páo Santo", ou "pau Setim". Os tremós, sempre de mogno com figuras de bronze douradas, os tampos em pedra branca, são exclusivos das salas de aparato, não se detectando a sua presença nos quartos ou "camaras", excepto na N.o 4 que servia de camarim ao quarto da então Princesa do Brasil. Há, pois, uma ordem no conjunto, que se repete, com apontamentos de objectos que diferenciam e definem a função destinada a cada espaço.

Os têxteis referidos no inventário do Paço do Ramalhão, de 1829, são preferencialmente de tons claros - amarelos, verdes, ou azuis, num caso- com detalhes de passamanaria que tendem a condizer com as cores das pedras que sobrepõem os móveis, criando um efeito de repetição e harmonia. Isto é, quando surge menção de o tampo ser de pedra preta, é provável existirem detalhes tais como os "Cadilhos côr de Roza e preta", as bambinelas sendo de "Cassa Lavrada", serem guarnecidas "de preto e amarello". Quando os móveis são dourados, as pedras dos tremós são brancas, e as ditas bambinelas são forradas de seda amarela e os detalhes surgem em "verdes e oiro". Na Relação de 1807, nas Câmaras a opção recai sobre a "nobreza azul claro" que forra armação de cama, a coberta e as cadeiras", no quarto da então Princesa do Brasil, ou o "azul ferrete", nos aposentos da Rainha, sua sogra. As cores claras escolhidas para os estofos, para as bambinelas e sanefas, ou para as armações das camas, que os inventários referem, de tecidos de seda ou damasco, ou da finíssima de cassa, assinalam um gosto pelo que é gracioso e leve, num quadro de referências estéticas que se afasta da opulência barroca, com os tons dourados e o amarelo a predominarem nas divisões que aparentam um cunho de maior aparato.

Os inventários relativos ao Paço do Ramalhão enquanto casa da Princesa do Brasil, ou mais tarde, enquanto Imperatriz-Rainha, assinalam a diversidade do mobiliário, testemunho de uma preocupação com o conforto, com a "arte de viver". No Arquivo do Museu Imperial de Petrópolis, localizamos documentação referente a inúmeras aquisições de móveis feitos por $D$. Carlota Joaquina, a fornecedores europeus, esssencialmente franceses, aquando da estada da corte portuguesa, no Rio de Janeiro. Numa relação de compras, datada de 1817 , do Rio de Janeiro, lá encontramos "does mesas com marmol branco, hum secretario á does colunnas com segredo, huma comoda á coluna muy rica, does Espelhos com ricos ornamentos [...], huma comoda de cahoba com colunnas, hum Espelho tocador com colunnas muyto ricas", 
entre outros objectos, a assinalar um gosto pelo que é novo ${ }^{156}$. E a confirmar a ideia de que, "onde quer que seja possível, o século XVIII tem um gosto apaixonado pelo novo"157, sendo os móveis que ficam fora de moda, reservados às residências secundárias, os mais novos destinados às residências principais.

Um gosto pelo que é novo que justifica não existir, no Paço do Ramalhão, menção às pesadas tapeçarias a decorar as paredes, ou a cobrir os móveis, moda de que se queixava William Beckford quando deambulara pelas casas senhoriais portuguesas, no final de setecentos. No seu lugar, em algumas salas, surgem as pinturas murais, com representações de uma natureza idealizada e exótica, dentro de um gosto que Jean Pillement ajudara a difundir na corte portuguesa, próximo já de uma sensibilidade pré-romântica. Em espaço próprio, ostentava-se a colecção de pintura, de temas diversificados que iam das naturezas mortas, às paisagens, dos retratos, à pintura de género e desta à pintura religiosa, revelando um gosto eclético e actualizado.

Na decoração interior não há lugar para os espaços vazios, pela quantidade de referências que observamos para cada divisão. Um desejo de conforto a determinar que ao mobiliário se associassem os têxteis e a estes a decoração mural, com com motivos inspirados nos modelos decorativos da Antiguidade Clássica, atribuíveis ao pintor Manuel da Costa, que acompanha Costa e Silva nas diversas empreitadas de renovação e construção de empreendimentos régios, anteriores à partida da corte para o Brasil, em 1807. Na sala de jantar as pinturas de paisagens idealizadas, exóticas e tropicais, a anunciarem uma sensibilidade estética préromântica, de idealização da natureza enquanto lugar de refúgio e evasão.

\footnotetext{
${ }^{156}$ Museu Imperial de Petropolis, Arquivo, coleç̧ão POB, D 1789, M.42. Agradeço à Dr.a Valeria Gauz, do Instituto Brasileiro de Museus, as facilidades concedidas na obtenção das cópias digitalizadas da documentação, apesar das dificuldades igualmente vividas por aquelas instituições culturais brasileiras. ${ }^{157}$ CHAUNU, Pierre, A Civilização da Europa das Luzes, Volume II, Editorial Estampa, 1995, p. 159.
} 


\section{IV - A centralidade da arte na cultura de oitocentos. A “Caza da Pintura № 9"}

Para o tema de que nos ocupamos, isto é, o estudo das colecções de arte, importa destacar pelo seu conteúdo, na relação, datada de 1807, a denominada "Caza da Pintura no 9", onde se concentravam as colecções de pintura, bem como os objectos de história natural, que constituíam o "Muzeu", termo este que surge no inventário de $1829^{158}$, e não no de $1807^{159}$ que temos vindo a seguir.

Naquela, para além das 16 cortinas e 8 bambinelas, do "lustre de alabastro de 8 lumes guarnecido com 8 figuras do mesmo alabastro", das "2 collunas brancas tendo cada huma em sima huã bacia gr.de de loiça da China", dos 2 "Espelhos de Vestir guarnecidos com remates de bronze doirado e pés broziados", são mencionados "71 Quadros de moldura doirada", "97 D.os D.a de pau Santo", "12 D.os com fructas d'America em Vulto"160, somando, no conjunto, 180 obras, algumas de elevado valor artístico, como veremos. Esta sala poderia conjugar o perfil de uma "Galeria de Pintura", com o de Gabinete de Curiosidades, a confirmar-se nela se exporem, de igual modo, as curiosidades botânicas e animais, que a documentação refere.

Importa aqui fazer um esclarecimento no que à designação de "Museu" respeita. Diz João Carlos Brigola ser mais rigorosa a utilização do termo "Gabinete", ao de "Museu", referindo, no entanto, a evolução semântica que faz alterar os termos, podendo "dar-se que "Museu" corresponda ao conteúdo (como que identificado com "Colecção") e "Gabinete" se refira ao continente, ao edifício que o alberga $[. . .]^{161}$. Seguindo esta definição, parece-nos então ser a designação de "Museu", no contexto das colecções de D. Carlota Joaquina, aplicável ao conjunto de curiosidades botânicas, animais e minerais de que dispunha a soberana e que podemos associar a referências, contidas no Inventário de 1829, a "trinta e hum quadros muito deneficados pertencentes ao Mozeu", "trez maquinetas de vidro com pássaros dentro", e "Sinco Gaiollas da China e hum pao de alicorne", "dois globos celestes e terrestres"162, ou, no catálogo do leilão da Bemposta, com o n. 57, a "Um dito de Historia Natural, de diversas

\footnotetext{
158 ANTT, Casa Real, Cx. 3703, n.o 387.

${ }^{159}$ ANTT, Casa das Rainhas, Livro 234 (1807).

${ }^{160}$ ANTT, Casa das Rainhas, Livro 234 (1807).

${ }^{161}$ BRIGOLA, João Carlos, Os viajantes e o "livro dos museus". As colecções portuguesas através do olhar dos viajantes estrangeiros (1700-1900). Dafne Editora, Porto 2010, p. 12.

162 ANTT, Cx. 3703. Tanto os dois globos celestes e terrestres, como os "doze mapas em papel" que o inventário refere encontramo-los na relação de 1829, na Casa da Arrecadação, pelo que poderiam integrar uma zona de estudo dos príncipes.
} 
qualidades de Passaros embalsamados, com caixilhos de vidro", aos quais se atribuía um valor semelhante ao do "Retrato de Luis XVI Rey de França", isto é, $14 \$ 400^{163}$, ou, com o n.o $948 \mathrm{~N}$ 1, a "12 Quadros de museo de fructas do Brasil [...] em mto mao estado"164.

A estes objectos podemos, ainda, associar o conjunto de minerais que teriam sido enviados para o Laboratório Químico da Escola Politécnica para exame e avaliação, conforme nota, datada de 20 de Agosto de 1848, de D. Manuel de Portugal e Castro para o Almoxarife da Bemposta. Nesta, é-lhe feita a seguinte comunicação "Por ofício de 28 do p. me participa o Ministro da Guerra ter dado as suas ordens ao Director da Escola Polytechnica para que no Laboratório Chimico da mesma Escola seja examinada e avaliada, logo que alli seja apresentada, a porção de minerais do Espolio que ficou de Sua Mag.de Imperial e Real a Sr.a D. a Carlota Joaquina de Bourbon"165. O que não deixe de ser um testemunho eloquente da diversidade de interesses que moviam a curiosidade intelectual da soberana portuguesa e que abrangiam os domínios das ciências da natureza.

Este conjunto de referências leva-nos a concluir que o "Muzeu", a que os documentos aludem, deveria corresponder ao espírito de um Gabinete de Curiosidades e naturalia, de nítido recorte iluminista, no qual a diversidade de elementos botânicos, do mundo mineral e animal, o "theatro da natureza", expressava um desígnio de conhecimento, através da observação prática, de tipo enciclopédico, do mundo natural.

Diderot, no artigo da Encyclopédie referente aos Gabinetes de História Natural, dedica-lhes palavras elogiosas, pois considera que a tarefa de recolha e organização dos objectos naturais testemunham uma vontade de instrução, pelo que tanto o "curioso", como o "amador", cujo espírito condena, a partir do momento em que se dedicam a esta actividade tornam-se respeitáveis, colocando-se ao mesmo nível dos "sábios"166. Observamos pois, aqui, nestas referências a objectos mineralógicos, cruzadas com as notícias relativas a experiências

\footnotetext{
${ }^{163}$ Relação dos Quadros pertencentes á Herança da Imperatriz Rainha a Senhora D. Carlota Joaquina de Bourbon, hoje existentes no Real Palacio da Bemposta, onde hão-de ser vendidos em hasta publica, perante o Juiz do respectivo Inventario [...] e que forão descriptos e avaliados pelos Senhores António Manoel da Fonseca, Lente de Pintura Histórica da Academia das Bellas Artes de Lisboa, e Luiz Tirinnanzi, Pintor restaurador de quadros [...], assinado pelo Solicitador da Caza Real, Francisco de Caldas Aulete, Lisboa 1844.

${ }^{164}$ Adquiridos a 12 de Junho, por Julião Paulino Figueiredo da Costa. ANTT, Casa Real, Cx. 7311, maço 91.

${ }^{165}$ ANTT, Caixa 7100, XX/2/81.

166 POMIAN, Krzysztof, "Médailles/coquilles = érudition/ philosophie», Collectionneurs, amateurs et curieux. Paris, Venice: XVIe - XVIIIe siècle, Éditions Galimard, Millau, 2001, p. 161.
} 
laboratoriais a que assistia a Família Real no Brasil ${ }^{167}$, um intuito de aperfeiçoamento do conhecimento, a partir da observação prática, que podemos atribuir a este conjunto de objectos, cuja referência surge dispersa em diversa documentação, como já aludimos.

Este "Museu" deveria integrar a "Caza da Pintura № 9", uma vez que alguns dos objectoscuriosidades são lá referenciados. No entanto, nada sabemos sobre a disposição cénica, a ordenação e apresentação desta colecção. E o mesmo se pode afirmar no que respeita à pintura, pelo que qualquer formulação acerca da disposição dos objectos poderia traduzir-se "num exercício de improvável rigor histórico", como escreve J. C. Brigola, a propósito do Real Gabinete de História Natural da Ajuda ${ }^{168}$, erro no qual não queremos incorrer.

No que respeita aos "quadros" mencionados no inventário de 1807, integravam a colecção de pintura de D. Carlota Joaquina, sendo a sua presença prévia à chegada da herança paterna que, sabemos, apenas sucederá duas décadas mais tarde. Mas sabemos igualmente, pelo que decorre da documentação, que a colecção estaria maioritariamente reunida num espaço, a “Caza da Pintura № 9", o "Gabinete" que João Caetano Rivara já mencionara na gravura ${ }^{169}$ que dedica à Princesa, provavelmente preenchendo as paredes, dada a quantidade de que há nota. Já naquela ocasião a então Princesa do Brasil dispunha das duas paisagens de Pillement "um dito representando os Aquedutos da Agua livre, outro a entrada da Barra de Lisboa, [...] largura quatro palmos, altura dous e três quartos", que no catálogo do leilão da Bemposta têm o n.으 99170; das duas naturezas-mortas de Antonio de Pereda y Salgado (1599-1669) ${ }^{171}$, ou de duas outras, de dimensões semelhantes, assim descritas "Um quadro em pano, Garrafas, copos e

\footnotetext{
167 V. a este propósito texto do blog da Biblioteca da Ajuda, Cultura e o ensino científicos na corte joanina do Rio de Janeiro: um testemunho, elaborado a partir de um manuscrito que integrou a que foi outrora a livraria da Rainha D. Carlota Joaquina de Bourbon - Catálogo da Livraria que foi de S. Mag.de a Senhora D. Carlota Joaquina de Bourbon (cód. 51-XIII-7) que nos testemunha sobre os primórdios do ensino científico na corte Joanina, do Rio de Janeiro. http://bibliotecadaajuda.blogspot.com/2018/02/cultura-e-o-ensino-cientificos-na-corte.html

${ }_{168}$ BRIGOLA, João Carlos, Os viajantes e o "livro dos museus", Porto 2010, p. 18.

169 SOARES, Ernesto, História da Gravura artística em Portugal, 1940, p. 518, n.o 1703. Afirma Ernesto Soares, desta obra apenas conhecer o exemplar existente na Biblioteca Nacional do Rio de Janeiro.

170 Duas paisagens de Pillement adquiridas pelo Conde de Clarange de Lucotte, no leilão da Bemposta, na sessão de 30 de Maio 1848. ANTT, Casa Real, Cx. 7311, maço 91.

${ }^{171}$ Adquiridas pelo Estado português, actualmente no Museu Nacional de Arte Antiga, Natureza Morta com Cesto de Frutas, inv. 469 Pint MNAA e Natureza Morta com empada, legumes e aprestos de cozinha, inv. 470 Pint MNAA. Ambas as pinturas foram trazidas para Portugal por Carlota Joaquina de Bourbon (1775-1839), na ocasião do seu casamento com o príncipe D. João, futuro D. João VI (17671826), em 1785. No início do século XIX pertenciam ao recheio do Palácio do Ramalhão (Sintra). $O$ Estado comprou ambas as pinturas no leilão do Palácio da Bemposta. V. catálogo da exposição $A$ perspectiva das coisas. A natureza-Morta na Europa, Volume I. Fundação Calouste Gulbenkian, Lisboa, Fevereiro de 2010.
} 
Flores, largura dous palmos, altura dous e um oitavo"172 e "Um dito em pano, representando um Cópo com vinho, Cogumellos e Rabanetes, com uma faca metida em perspectiva, por Jorge Akactrit [...], moldura dourada"173; o retrato de Luís $\mathrm{XVI}^{174}$; ou ainda, as pinturas de temática mitológica que encontramos no catálogo do leilão da Bemposta, tais como, "um dito representando Vénus no Toucador com diversos Paineis e objectos d'Artes, Joias e outras preciosidades [...]", ali atribuído a "Brugel, aveludado"175, "O Banho de Diana, pelo Cavalleiro Delpino"176, ou “Um quadro em pano, de meia figura colossal, representando o Apollo, original de Dominiquino"177, "Um quadro em pano a óleo representando Ulisses e Ector, Escola de Paulo Veronese"178, "Um Bacho, escola de Nicolao de Pussin"179; ou as "veduttas" assinaladas na pintura "Vista da Igreja de S. Francisco em Roma, Escola Romana"180, ou nas duas pinturas "Ruínas de Roma, por um Escolar de Francisco Pannini" e "Ruinas de Roma, original de Pannini"181; ou nas pinturas de pequeno formato, comuns nos Gabinetes do "amador" de pintura, representando "O Philosopho Esopo, por Salvator Roza, e um dito representando Vulcano", ambos com o N. 5 no catálogo do leilão da Bemposta ${ }^{182}$, ou dentro da pintura de género, "um quadro pequeno, em taboa, representando o Jantar dos Macacos, cópia de David

\footnotetext{
172 N.o 94 do catálogo do leilão da Bemposta, adquirido pelo sr. João Ortega, no dia 8 de Junho de 1848, com abatimento no valor inicial. ANTT, Casa Real, Cx. 7311, maço 91.

${ }^{173}$ NN. 96 do catálogo do leilão da Bemposta, adquirido por António Borges da Câmara, na sessão de 15 de Junho de 1848. ANTT, Casa Real, Cx. 7311, maço 91.

174 N.o 38 do catálogo do leilão da Bemposta, descrito como "um dito, representando Luiz XVI, Rey de França, corpo inteiro; cópia, largura quatro palmos e um terço, altura seis e um quarto, moldura dourada", com um valor atribuído de $14 \$ 400$ e que foi adquirido na sessão de 15 de Junho de 1848 , por Hermano Frederico Moser, por $2 \$ 400$. ANTT, Casa Real, Cx. 7311, maço 91.

${ }^{175}$ N .098 do catálogo do leilão da Bemposta, adquirido pelo colecionador Hermano Frederico Moser, na sessão de 15 de Junho de 1848. ANTT, Casa Real, Cx. 7311, maço 91.

${ }^{176}$ N. 04 do catálogo do leilão da Bemposta, adquirido pelo colecionador Jacinto da Silva Falcão, no dia 5 de Junho de 1848. ANTT, Casa Real, Cx. 7311, maço 91.

177 Domenico Zampieri, il Dominiquino (Bolonha 1581-Nápoles 1641), pintor do barroco italiano. Esta pintura tinha o N.o 118 do catálogo do leilão da Bemposta, adquirido pelo sr. João de Hortega, na sessão do dia 8 de Junho de 1848. ANTT, Casa Real, Cx. 7311, maço 91.

178 Paolo Caliari Veronese (Verona 1528-Veneza 1588). Esta pintura tinha o N.o 34 do catálogo do leilão da Bemposta, adquirido pelo sr. Raimundo José Pinto, no dia 15 de Junho de 1848. ANTT, Casa Real, Cx. 7311, maço 91.

${ }^{179}$ Nicolas Poussin (Les Andelys 1594-1665 Roma). Esta pintura tinha o N.o 122 do catálogo do leilão da Bemposta, adquirido pelo Sr. António Borges da Câmara, na sessão do dia 11 de Junho de 1848. ANTT, Casa Real, Cx. 7311, maço 91.

180 Tinha o n.o 84 do catálogo do leilão da Bemposta.

${ }^{181}$ Estas duas pinturas tinham, respectivamente, os n. ${ }^{05} 52$ e 53 do catálogo do leilão da Bemposta, tendo sido adquiridas pelo Sr. Jacinto da Silva Falcão, na sessão do dia 5 de Junho de 1848. ANTT, Casa Real, Cx. 7311, maço 91.

${ }^{182}$ Salvatore Rosa (Nápoles 1615-Roma 1673). Esta pintura integrava o catálogo do leilão da Bemposta com o N.o 5, e foi adquirida pelo Sr. António Borges da Câmara na sessão do dia 1 de Junho de 1848. ANTT, Casa Real, Cx. 7311, maço 91.
} 
Teniers"183, e ainda as obras de temática religiosa, descritas como "N. a Sr. a da Conceição o Padre Eterno e Anjos por Conca o quadro grande do m.mo Autor existe em Mafra (...)"184, ou de autores portugueses como Domingos António Sequeira (1761-1837), com "S. Pedro de Alcântara arrebatado em extâse pelos Anjos". Esta era uma das raras obras atribuídas a um pintor português a que o catálogo da Bemposta alude. A compensar essa menor representação, encontramos a menção a diversas gravuras de autores portugueses, de entre os quais podemos reconhecer, continuando a citar o catálogo do leilão da Bemposta, Vieira Portuense (1765-1805), com a obra "Sacra Família [...] invenção de Vieira Portuense gravada por Queiroz"185. Seria a gravura "Sagrada Família" que Vieira dedicou à então Princesa do Brasil ${ }^{186} \mathrm{E}$, ainda "O Juramento de Viriato, desenhada por Vieira Junior", bem como diversas outras "abertas por Bartholozi"187, artista que ocupou um lugar destacado na formação dos gravadores portugueses, quer como mestre dos bolseiros régios em Londres, quer, a partir de 1802, em Lisboa, na direcção da "escola de gravura adido à Imprensa Régia"188. A ligação de D. Carlota Joaquina a alguns destes artistas, da qual subsiste documentação, pode justificar a presença de um número significativo de gravuras na sua colecção, demonstrando o momento de criatividade que então se vivia no Reino, nesse campo específico de expressão artística, que servia múltiplos propósitos, desde os de carácter didático-pedagógico ${ }^{189}$, aos religiosos e de propaganda política, num momento de grande fractura e polarização ideológicas.

\footnotetext{
183 Referência a David Teniers, o Jovem (Antuérpia 1610-Bruxelas 1690), ou a seu pai, com o mesmo nome? Tinha o N.o 103, no catálogo do leilão da Bemposta e foi adquirido pelo colecionador Raimundo José Pinto.

${ }^{184}$ Esta pintura seria um estudo para a obra de maior dimensão existente no Palácio Nacional de Mafra, n.o inv. PNM 7501, atribuída ao pintor italiano Sebastiano Conca (1680-1764), encomendada por D. João V (1689-1750) para a Sala dos Atos Literários, onde se encontra. Tinha o N. 139 no catálogo do leilão da Bemposta, sendo adquirida pelo Sr. António Borges da Câmara, na sessão do dia 15 de Junho de 1848.

185 Integrava um conjunto de cinco gravuras com o n.o 157 e foi adquirida pelo Sr. D. José Maria da Costa Silveira da Motta, no dia 19 de Junho de 1848. ANTT, Casa Real, Cx. 7311, maço 91.

186 SOARES, Ernesto, História da Gravura Artística em Portugal, Lisboa, 1940. Ver Tomo I, p. 651, refere, com N.o 2198, "Sagrada Família - Cena passada nas margens de um rio [...]. Dedicada a S.A.R. a Princeza do Brasil Nossa Senhora por F. Vieira Port. Pintor de Hist. Penc. de S.M.F. London Published as the Act directs Jan. A. 1799". E. S. apenas refere uma obra de Vieira com esta temática.

187 Integravam o catálogo do leilão da Bemposta, com o n.o 157, constituído por 5 gravuras. O lote N. 46 integrava mais 2 gravuras - "uma de Vieira, e outra de Mr. Doucier", sem indicação de tema.

188 FARIA, Miguel Figueira de, "A Imagem Impressa: produção, comércio e consumo de gravura no final do Antigo Regime", Tese de Doutoramento, Repositório Camões, UAL, 2005, p. 193. http://hdl.handle.net/11144/2490. Consulta online, 3 de Março de 2019.

189 Veja-se, a propósito da importância da renovação da Impressão Régia, para a divulgação da gravura, promovida em finais de 1801, por iniciativa de D. Rodrigo de Sousa Coutinho, FARIA, Miguel Figueira de, A Casa Literária do Arco do Cego: Exemplo Singular na História da Edição llustrada em Portugal. Apontamentos para uma biografia. Repositório Camões, 2001. http://hdl.handle.net/11144/2479. Consulta online, Janeiro de 2019.
} 
Podemos ainda nomear diversos retratos, desde o de "Luis 16 Rey de França", sem autoria atribuída, que figurava com o n.o 38 do catálogo da Bemposta ${ }^{190}$, um outro que representa "Dois irmãos, corpo inteiro, Escola Veneziana", com o n.o 37, ou o retrato de "El Rey o Senhor D. João VI, Autor incógnito", n. 17 do referido catálogo, nenhuma destas pinturas tendo relação com as incluídas na "Tercera Division", isto é, com as provenientes da quota hereditária paterna.

Assim, do confronto da diversa documentação, identificamos algumas pinturas que integravam a colecção de D. Carlota Joaquina, prévias à chegada daquelas que integraram a quotahereditária, e que nos merecem algumas notas.

\section{IV.I - Das Paisagens}

As Pinturas de Jean Pillement (1728-1805). O modo como as pinturas de Jean Pillement ${ }^{191}$ chegam à posse de D. Carlota Joaquina é, para nós, desconhecido. Supomos, no entanto, que possa ter sido por intermédio de D. Carlos Gutierrez de Los Rios (1742-1795), Conde de Fernan Nuñez, embaixador de Carlos III na corte de Lisboa, a quem coubera a recepção da infanta espanhola D. Carlota Joaquina, na sua chegada à corte portuguesa, em 1785, aquando do seu casamento com o então infante D. João.

Segundo documentação existente na Biblioteca da Ajuda, e de acordo com a "Carta d'Off.do Ministro da Sardenha p. o Conde de Pherron na Corte de Turim", datada de 23 de Janeiro de 1787, aquando do naufrágio ao largo de Peniche, do galeão espanhol S. Pedro de Alcântara, a Câmara de Comércio de Cádiz, com a permissão do rei de Espanha, teria enviado ao Conde, duas pinturas encomendadas a Pillement - "dont l'un represente la pêche des effets naufragés, et l'autre le naufrage du vaisseau S. Pedro avec une inscription très flatteuse pour Mr.l'Embass.r.". Ao valor das obras de arte associava-se o presente suplementar com o qual aqueles comerciantes quiseram agraciar o embaixador de Espanha, pelo seu empenho no

\footnotetext{
${ }^{190}$ Adquirido no leilão da Bemposta pelo Sr. Hermano Frederico Moser, na sessão do dia 15 de Junho de 1848. ANTT, Casa Real, Cx. 7311.

${ }^{191}$ Jean Pillement (1728-1805), paisagista francês, que viajou em Portugal em três períodos sucessivos. V. ARAÚJO, Agostinho, Experiência da Natureza e Sensibilidade Pré-Romântica em Portugal. Temas de Pintura e seu consumo (1780-1825, Dissertação de Doutoramento em História da Arte, Fac. Letras do Porto, 1991. http://hdl.handle.net/10216/13668. Consulta em Janeiro de 2019.
} 
resgate da carga do navio "Ces tableaux superbement encadrés, avoient pour attaché une barre d'or chacun avec des anneaux du même metal de la valeur de de 30.m." 192

O apreço do embaixador pela obra do mestre lionês levara-o a adquirir mais duas pinturas que representavam uma Vista do Aqueduto das Aguas Livres e outra, Barra de Lisboa. Diogo de Macedo, em artigo da Revista Ocidente ${ }^{193}$, de 1940, testemunha o facto de, em Madrid, a colecção dos Duques de Fernan Nuñez integrar quatro pinturas de Pillement, sendo duas obras relacionadas com o naufrágio do galeão S. Pedro de Alcântara que julgamos serem as atrás mencionadas e mais duas outras que teriam sido adquiridas pelo Conde de Fernan Nuñez nos anos em que esteve em Lisboa, como embaixador ${ }^{194}$. O par de pinturas da colecção de D. Carlota Joaquina que surge no catálogo do leilão da Bemposta, respectivamente "Aqueduto das Águas Livres" e "Entrada da Barra de Lisboa", vendidas na sessão de 30 de Maio 1848, ao Sr. Conde de Clarange de Lucotte ${ }^{195}$, leva-nos a equacionar o possível envolvimento do então Embaixador de Espanha na sua obtenção, já que estas têm exactamente o mesmo tema do que as por ele adquiridas. Teriam, tanto o par da colecção de D. Carlota, como o da colecção do Conde de Fernan Nuñez, sido uma encomenda do Embaixador de Espanha ao pintor lionês, seguida de oferta, à neta do seu soberano? É uma hipótese que fica em aberto.

Era grande a reputação na corte portuguesa de que gozava Pillement e o interesse do diplomata espanhol pelo "artista é bem sintomático, tanto da penetração deste nos altos círculos da sociedade portuguesa, quanto da sintonia do embaixador com o gosto da corte de Madrid, então atraída pelo paisagismo francês protagonizado por Claude-Joseph Vernet mas também pelo próprio lionês"196.

\section{IV.II - Das Naturezas Mortas}

\section{As duas "Natureza-Mortas de António de Pereda y Salgado (1611-1678)"}

- Natureza Morta com Cesto de Frutos, óleo sobre tela, Museu Nacional de Arte Antiga, n.으 inv. 469 Pint $^{197}$;

\footnotetext{
192 BA. 51-XII-10, n. 46, datada de 22 de Janeiro de 1787.

${ }^{193}$ MACEDO, Diogo de, "Notas de Arte", Ocidente, volume VIII, n.o 23, 1940, pp. 608-609.

${ }^{194}$ ARAÚJO, Agostinho, 1991, p. 181. http://hdl.handle.net/10216/13668. Consulta em Janeiro de 2019.

${ }^{195}$ ANTT, Casa Real, Livro 2979.

${ }^{196}$ ARAÚJO, Agostinho, Experiência da Natureza e Sensibilidade Pré-Romântica em Portugal. Temas de Pintura e seu consumo (1780-1825, Dissertação de Doutoramento em História da Arte, Fac. Letras do Porto, 1991, p. 181 http://hdl.handle.net/10216/13668. Consulta em Janeiro de 2019.

197 http://www.matriznet.dgpc.pt/MatrizNet/Objectos/ObjectosConsultar.aspx?ldReg=249007.
} 
- Natureza Morta com Empada, Legumes e Aprestos de Cozinha, óleo sobre tela, Museu Nacional de Arte Antiga, n. inv. 470 Pint $^{198}$.
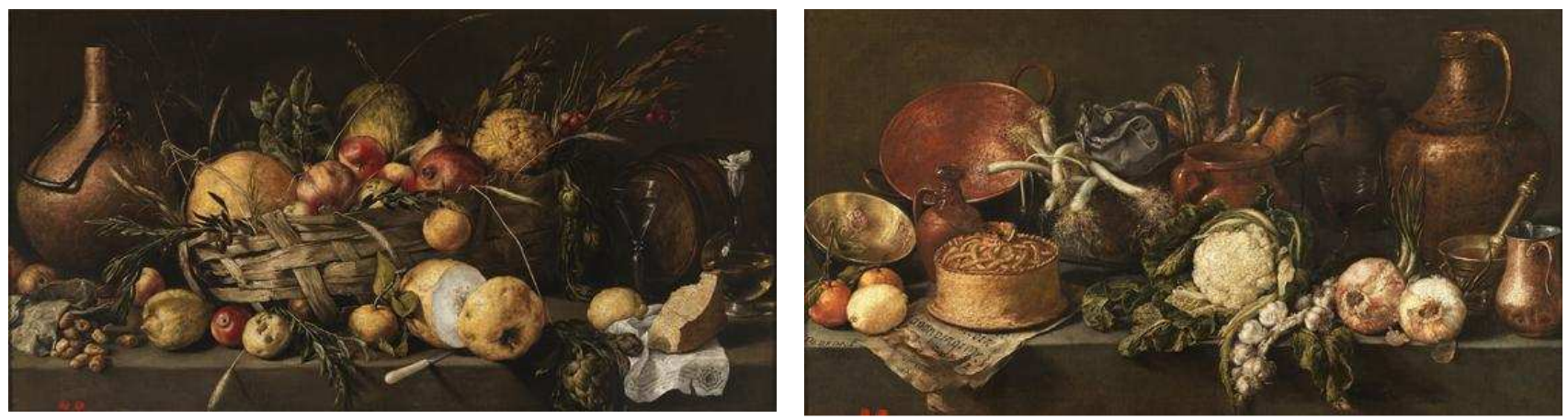

Natureza Morta com Cesto de Frutos, inv. 469 Pint. MNAA e Natureza Morta com Empada, Legumes e Aprestos de

Cozinha, inv. 470 Pint. MNAA.

Este par de pinturas foi adquirido pelo Estado português no leilão da Bemposta, pertencendo actualmente às colecções do Museu Nacional de Arte Antiga ${ }^{199}$, sendo demonstrativas do grau supremo ao qual a pintura espanhola levou a representação de objectos inanimados, associável a mensagens de cunho moralista, sobre a transitoriedade dos bens terrenos e a precariedade da vida; ou, ao desejo de representação da natureza, tão caro à cultura Iluminista, num tempo que devotou especial interesse à história natural. Julga-se que terão vindo com a infanta D. Carlota Joaquina, de Espanha, aquando do seu casamento com o Infante D. João, em 1785, sendo testemunho da versatilidade artística do pintor espanhol e da sua capacidade de transmissão da realidade física dos objectos ${ }^{200}$.

\section{IV.III - Da Pintura de Género}

A referência ao "quadro pequeno, em taboa, representando o Jantar dos Macacos, cópia de David Teniers" 201 , surge em diversas fontes. Assim, na "Relação dos efeitos que contem os 29 caixotes da Princeza Nossa Senhora, e que se encaixotarão em Queluz", em Fevereiro de 1809 com destino ao Rio de Janeiro, num caixote N.1 10, para além da menção a dois painéis de "Nossa Snr.a com hum menino", também é mencionado "1 D.o de Bamboxata de Macacos",

\footnotetext{
$198 \mathrm{http} / / /$ www.matriznet.dgpc.pt/MatrizNet/Objectos/ObjectosConsultar.aspx?IdReg=249008.

${ }^{199}$ Estas pinturas estão ambas abrangidas pela classificação de "interesse nacional", pela necessidade de acautelamento de especiais medidas sobre o património cultural móvel de particular relevância para a Nação.

${ }^{200}$ Catálogo da Exposição A Perspectiva das Coisas. A Natureza-Morta na Europa. Volume I, Séculos XVIIXVIII, Fundação Calouste Gulbenkian, 2010, pp. 21-22.

${ }^{201}$ Referência a David Teniers, o Jovem (Antuérpia 1610-Bruxelas 1690), ou a seu pai, com o mesmo nome? Tinha o N.o 103, no catálogo do leilão da Bemposta e foi adquirido pelo coleccionador Raimundo José Pinto.
} 
que volta de novo a surgir na relação de 1829 como "1 quadro de moldura doirada com bambuxata de Macacos". No catálogo do leilão da Bemposta, com o no 82, voltamos a encontrar referência a "uma Bamboxata", atribuída a "David Teniers (cópia de)" que julgamos possa ser aquela e não a que integrou a quota hereditária, apenas descrita como "Una Bambochada, si nombre de autor", não mencionando nenhuma figuração e que integrava o lote das pinturas melhores ${ }^{202}$. Esta era uma das pinturas de género que poderia ter integrado 0 Gabinete de D. Carlota Joaquina, antes da chegada das pinturas correspondentes à herança paterna.

\section{IV.IV - Da Pintura Religiosa}

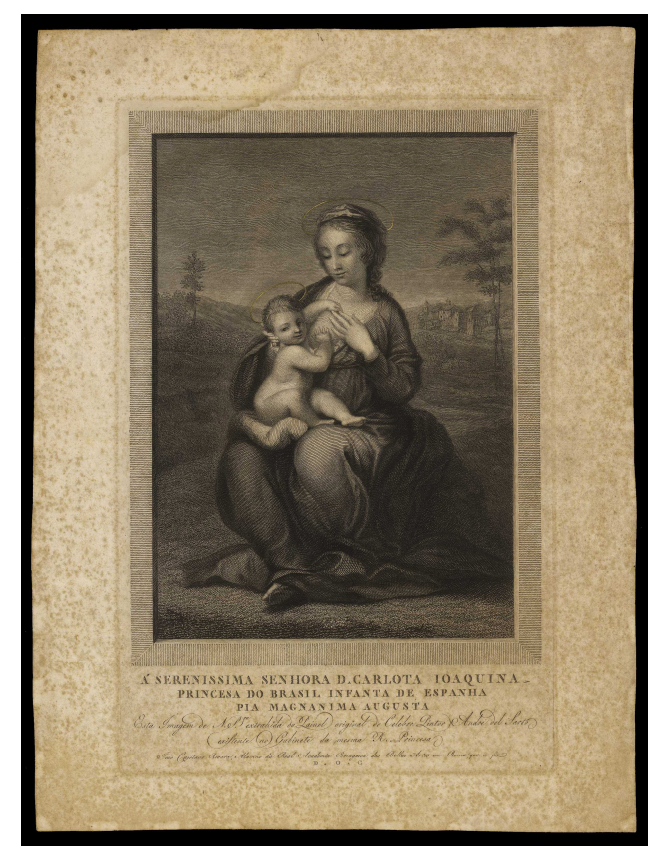

Nossa Senhora e o Menino, João Caetano Rivara, Fundação da Biblioteca Nacional do Rio de Janeiro.

Uma gravura, neste caso - Nossa Senhora e o Menino, de João Caetano Rivara, existente na Biblioteca Nacional, Rio Janeiro, para além do seu valor artístico reveste-se de especial significado por documentar a presença de uma pintura de André del Sarto, no "Gabinete" da então Princesa do Brasil, a partir da qual o autor tinha feito aquela representação, conforme se lê na legenda À Sereníssima Senhora D. Carlota Joaquina, Princesa do Brasil, Infanta de Espanha, Pia Magnanime Augusta, Esta Imagem de N. Sr. $\underline{a}$ extrahida do Painel original do

202 Na Tercera Division, BA ms. 54-X-33, surge com o n.o 253, "Una Bambochada, si nombre de autor" que integrava o lote das pinturas melhores. No catálogo do leilão da Bemposta, com o n.o 82, "uma Bamboxata", atribuída a "David Teniers (cópia de)" que julgamos ser a mesma já mencionada em uma relação de 1809, citada em PIRES, António Caldeira, História do Palácio Nacional de Queluz, Coimbra 1926, p. 324. 
Celebre Pintor André del Sarto existente no Gabinete da mesma R. Princesa, João Caetano Rivara, Alumno da Real Academia Portuguesa das Bellas Artes em Roma. DOC. ${ }^{203}$

Desta pintura resta-nos apenas o rasto na gravura, pois não conseguimos localizá-la. Pertenceria ao núcleo da pintura religiosa da colecção que seria o que reunia o maior número de obras, de acordo com o catálogo do leilão da Bemposta. Só da representação de Nossa Senhora com o Menino Jesus encontramos seis referências, naquele catálogo, pelo que poderá ter sido, ou não, uma das vendidas por aquela ocasião.

"Nossa Senhora e o Menino Jesus em pé [...] cópia de Carlos Marati, feita por Trono", mencionada no catálogo do leilão da Bemposta, com o n.o $144^{204}$. Esta era uma obra de carácter devocional atribuída a "Trono", isto é, Giuseppe Trono (Turim, 1739-Lisboa, 1810), artista italiano ao serviço da corte portuguesa em finais de século XVIII, que se destacara enquanto retratista régio, tendo realizado várias representações da Princesa D. Carlota Joaquina muito jovem, por diversas ocasiões ${ }^{205}$, bem como de outros elementos da corte e da elite aristocrática lusitana, adquirindo fama como pintor e miniaturista ${ }^{206}$. Daquela pintura, tendo sido vendida no leilão da Bemposta, perdeu-se o rasto

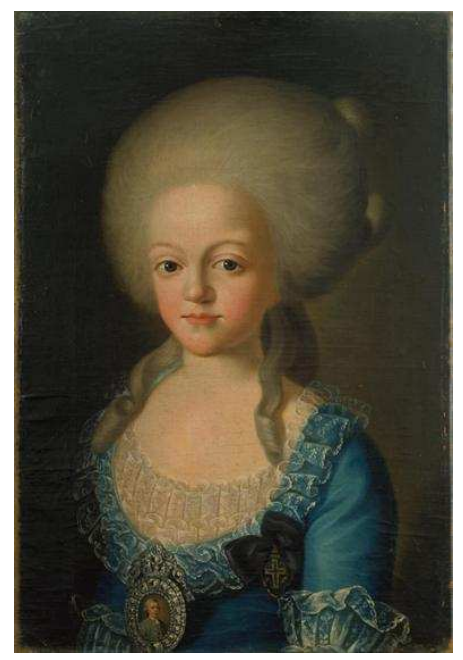

Retrato de D. Carlota Joaquina, Troni, Giuseppe, (atr.) (1739-1810), MNSR n.10 inv. $340 \mathrm{Pin}^{207}$. Este retrato deve ter sido realizado por altura do casamento da Infanta de Espanha com o Infante D. João, em 1785. Existem várias réplicas/cópias do mesmo. No Museu do Prado existe um interessante retrato de corpo inteiro Carlota Joaquina, infanta de España, reina de Portugal, no de catálogo P002416, datado de 1787, deste autor que deverá ter sido enviado para a corte de Espanha, pela rainha D. Maria I.

\footnotetext{
${ }^{203}$ SOARES, Ernesto, in História da Gravura Artística em Portugal. Os artistas e as suas obras, Tomo I, Lisboa, 1940, n.․1703, p. 518.

${ }^{204}$ A pintura foi adquirida no leilão da Bemposta pelo Sr. António Borges da Câmara, na sessão de 23 de Maio de 1848. ANTT, Casa Real, Cx. 7311, maço 91.

${ }^{205}$ V. Retrato de D. Carlota Joaquina, MNSR. Inv. 340 Pin CMP/MNSR. Este é um dos diversos retratos de D. Carlota Joaquina realizados pelo pintor.

206 DEGORTES, Michela; RAGGI, Giuseppina, "Giuseppe Trono, Pintor de Retratos na Corte portuguesa (1785-1810), in Artis, Revista Instituto História da Arte, Fac. Letras, Universidade de Lisboa, N.o 5, 2017, pp. 209-221; A Pintura de Giuseppe Trono na Capela do Paço da Bemposta, Edições Colibri, 2019.

${ }^{207}$ http://www.matrizpix.dgpc.pt/MatrizPix/Fotografias/FotografiasConsultar.aspx?TIPOPESQ=2\&NUMP $\mathrm{AG}=2 \& R E G P A G=50 \& C R I T E R I O=$ carlota + joaquina\&IDFOTO $=7522$.
} 


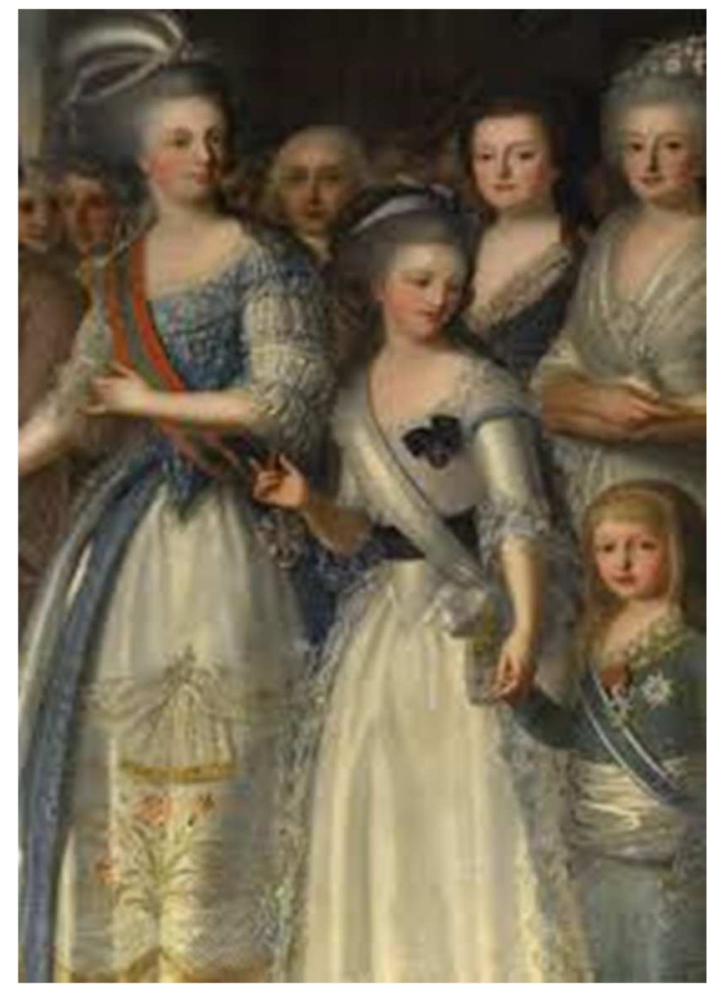

Pormenor da pintura "Consagração da monarquia portuguesa e do seu governo ao Sagrado Coração de Jesus", Giuseppe Trono, altar-mor da Capela do Palácio da Bemposta, Lisboa, na qual se vêm vários membros da família real, de entre os quais a Princesa $D$. Carlota Joaquina ao lado da sua sogra, a Rainha D. Maria I. É provável que por aquela ocasião já fosse viúva a princesa D. Maria Francisca Benedita, que se encontra na fila detrás ao lado de sua irmã, pois o Principe $\mathrm{D}$. José morrera em 1788, colocando a infanta de Espanha na posição de mulher do herdeiro da coroa, o Princípe D. João, com o qual casara em 1785.

S. Pedro de Alcântara arrebatado em extâse pelos Anjos, de Domingos António Sequeira (17611837), um óleo sobre cobre que mereceu elogios por parte do Conde A. Raczynski, por o considerar "un charmant petit tableau, bien pensé, bien saisie, traite avec délicatesse et d'un effet très ageable"208. Esta era uma das raras obras atribuídas a um pintor português, que o catálogo da Bemposta mencionava. Tendo sido adquirida pelo Estado português, pertence

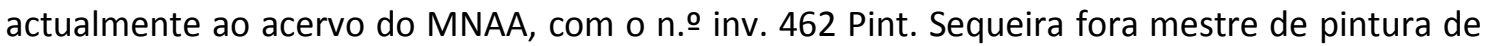
D. Carlota Joaquina e por isso não era surpreendente a presença de uma obra de sua autoria naquela colecção.

A Gravura que integrava o lote com o n. 157, do catálogo do leilão da Bemposta, descrita como "Sacra Família [...] invenção de Vieira Portuense gravada por Queiroz"209, que já anteriormente referimos, como a "Sagrada Família"210, descrita por Ernesto Soares, como uma

208 V. SANTOS, Paula Mesquita, “A Colecção de D. Carlota de Bourbon, oriunda do Ramalhão, em Sintra [...]", in Vária Escrita, n.o 2, Sintra 1995, pp. 307-308.

209 Integrava um conjunto de cinco gravuras com o n. 157 e foi adquirida pelo Sr. D. José Maria da Costa Silveira da Motta, no dia 19 de Junho de 1848. ANTT, Casa Real, Cx. 7311, maço 91. Era este o procurador da Infanta D. Isabel Maria pelo que não é certo que tenha comprado para si próprio, ou para aquela Infanta, de quem era representante na herança da Imperatriz Rainha. V. nota 186.

${ }^{210}$ SOARES, Ernesto, História da Gravura Artística em Portugal, Lisboa, 1940. V. Tomo I, N.o 2198, p. 651. 
"Sagrada Família - Cena passada nas margens de um rio [...]", dedicada por Vieira Portuense à então Princesa do Brasil, que estudaremos mais à frente.

Estas eram algumas das obras de arte que integravam o "Gabinete" de D. Carlota Joaquina, seu antes da herança paterna, e que cobriam um leque variado de tipologias, das naturezas mortas e paisagens ao retrato ou à pintura de carácter devocional, demonstrando um gosto ecléctico e esclarecido. 


\section{V - D. Carlota Joaquina e as Artes.}

De acordo com algumas fontes, teria sido em Julho de 1802 que D. Rodrigo de Sousa Coutinho ${ }^{211}$, então presidente do Real Erário, chamara Domingos António Sequeira (17681837), fazendo-o nomear "primeiro pintor da Câmara e Corte", situação em que emparceirava com Francisco Vieira Portuense (1765-1805), seu rival nos tempos de Roma. A ambos tinha já sido atribuída a co-direcção dos trabalhos da pintura decorativa do Real Palácio da Ajuda, cuja obra se iniciara nos finais de setecentos, bem como o de mestres de pintura da princesinha Maria Teresa, então com dez anos de idade, e da própria princesa D. Carlota Joaquina ${ }^{212}$.

Sara Marques Pereira na sua biografia dedicada à soberana refere os nomes de Domingos António Sequeira (1768-1837) e o de Gregório Francisco de Assis e Queiroz (1768-1845) ${ }^{213}$, como mestres da princesa.
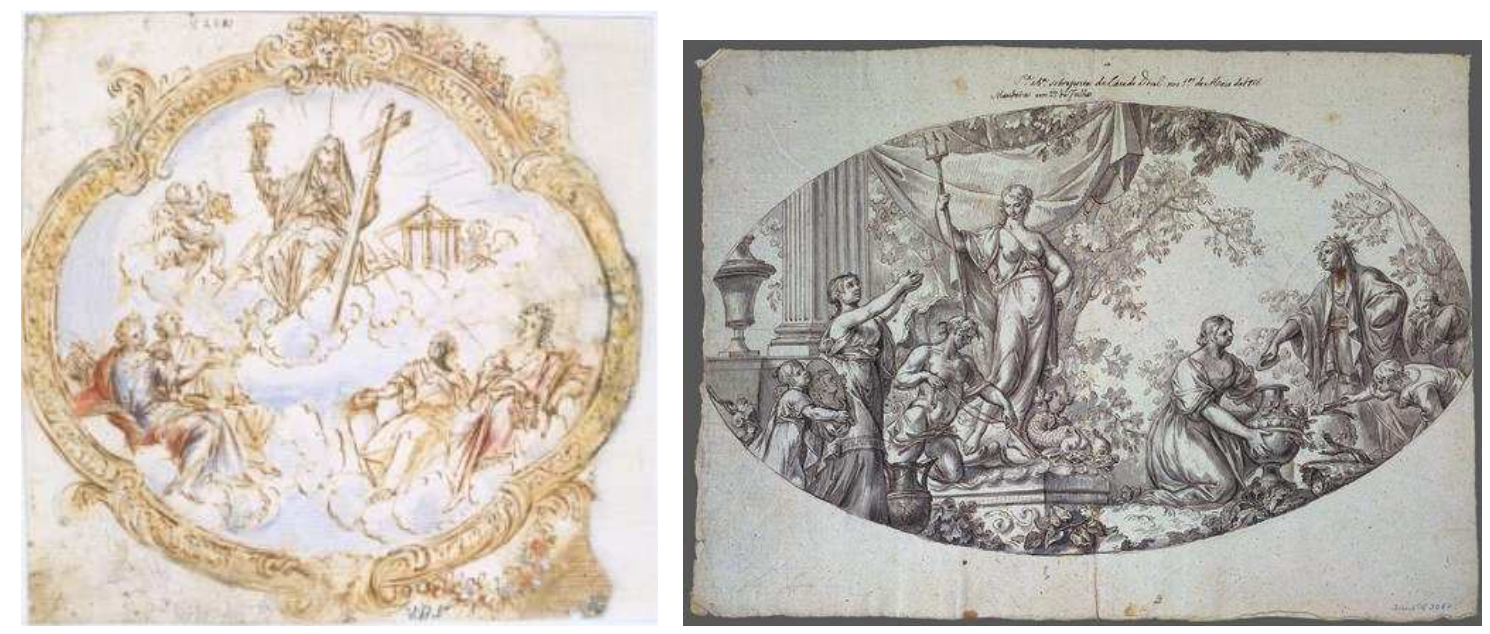

1 - Estudo medalhão para tecto da Capela do Palácio Nacional da Ajuda, Francisco Vieira Portuense, desenho, 1802-1804, inv. 2487 MNAA; 2 - Estudo para decoração de sobreporta Palácio da Ajuda, Cyrilo Volkmar Machado, c. 1816 , desenho, inv. 3064 MNAA.

211 "D. Rodrigo Domingos de Sousa Coutinho Teixeira de Andrade Barbosa: primeiro conde de Linhares, n. $1745 ; \mathrm{m}$. 1812. Diplomata e ministro notável. Serviu em Turim até 1795 , tomando seguidamente posse do cargo de secretário de Estado da Marinha. Conhecido, no plano da política externa, pela sua inalterável preferência pela aliança inglesa, que ele entendia ser a que melhor servia a prosperidade e independência de Portugal. No Brasil, para onde seguiu com a corte em 1807, destacou-se como ministro da Guerra e dos Negócios Estrangeiros e também como homem de vasta cultura e saber". In BONIFÁCIO, Maria de Fátima, Memórias do Duque de Palmela, D. Quixote, 2010.

212 FRANÇA, José-Augusto, A Arte em Portugal no século XIX, Livraria Bertrand, Lisboa, 1966, pp. 143144.

${ }^{213}$ PEREIRA, Sara Marques, D. Carlota Joaquina Rainha de Portugal, Livros Horizonte, 2008, p. 23. 
José Alberto Seabra, seguindo Cyrillo e Xavier da Costa ${ }^{214}$, refere a data de Setembro de 1803, como a da nomeação de Sequeira como "mestre de desenho e pintura da Princesa da Beira, D. Maria Teresa, a quem passou a dar lições, bem como a sua mãe, D. Carlota Joaquina, e a suas tias, D. Maria Francisca Benedita e D. Maria Ana"215, estas designadas por Xavier da Costa como "artistas-amadoras diligentes" ${ }^{216}$, com provas dadas na Basílica da Estrela, onde deixaram telas de sua mão 217 .

Terá sido, aliás, por intermédio de Sequeira, conforme refere Fernando Pamplona, que D. Carlota terá oferecido à Real Academia de Marinha e Comércio do Porto, "um desenho de sua autoria com duas pequenas cabeças de criança, cópia do gesso, assinado e datado: $D$. Carlota Joaquina, Princesa do Brasil - 1804", para a participação numa exposição que não chegou a realizar-se tendo, depois de várias vicissitudes, voltado à posse da Academia do Porto, que o terá apresentado, "em 1861, na Exposição da Associação Industrial Portuense"218, desenho que não logramos localizar.

Domingos António Sequeira (1768-1837) era, a par de Francisco Vieira Portuense (1765-1805), um dos mais prestigiados pintores portugueses, que aliás beneficiara do apoio régio para os estudos que empreendera em Roma. Segundo Varela Gomes, eram ambos exemplos de artistas portugueses que tinham tido uma "educação artística internacional" e relativamente aos quais não oferecia quaisquer dúvidas a plena "integração nas mais recentes correntes artísticas da Europa do final do séc. XVIII"219, pelo que naquela ocasião as infantas e Princesas dispunham de mestres especialmente qualificados.

No entanto, confrontando diversos testemunhos, verificamos que o interesse de D. Carlota Joaquina pela pintura é prévio aos ensinamentos dos artistas nomeados como seus mestres, já

\footnotetext{
214 MACHADO, Cyrillo Volkmar, Collecção de Memorias [...], 1823, p. 150; COSTA, Luís Xavier da, 1936, p. 22.

215 CARVALHO, José Alberto Seabra, "Uma cronologia", in Sequeira 1768-1837. Um português na mudança dos tempos, Museu Nacional de Arte Antiga, 1997, p. 102.

${ }^{216}$ COSTA, Luís Xavier da, O Ensino das Belas-Arte nas Obras do Real Palácio da Ajuda (1802 a 1833), Lisboa, ANBA, 1936, p. 22.

${ }^{217}$ V. a este propósito LIMA, Henrique de Campos Ferreira, Princesas Artistas (As filhas de El-Rei D. José), Imprensa da Universidade, Coimbra, 1925, pp. 8-12.

218 PAMPLONA, Fernando, Dicionário de Pintores e escultores Portugueses ou que trabalharam em Portugal, I Volume, Lisboa, 1954, p. 193; LIMA, Henrique de Campos Ferreira, Princesas Artistas (As Filhas de El-Rei D. José), Subsídios para a História da Arte Portuguesa, Imprensa da Universidade, Coimbra, 1925, p. 17.

${ }^{219}$ GOMES, Paulo Varela, "Correntes do Neoclacissismo Europeu na Pintura Portuguesa do século XVIII", Sep. do IV Simpósio Luso-Espanhol de História da Arte. Portugal e Espanha entre a Europa e Além-Mar, Instituto de História da Arte, Fac. Letras, Universidade Coimbra, 1988, p. 446.
} 
que as obras existentes no Palácio da Ajuda e que Ihe são atribuídas, são de feitura anterior à da nomeação quer de Sequeira, quer de Vieira Portuense, para o importante cargo de pintores régios, pois datam as mesmas dos anos 1795 e 1796, como à frente veremos.

Sabemos, de igual modo, através de documentação localizada na Torre do Tombo, serem de data anterior àquela nomeação, as encomendas que a Princesa faz em Londres, de materiais para o exercício da sua actividade artística, para as quais fora intermediário Manuel Marques de Aguilar (1767-1816), bolseiro régio naquela cidade, e que podem justificar o modo como este artista representou a que seria sua mecenas.

Vejam-se, a título de exemplo, duas gravuras de Marques Aguilar, localizadas na colecção da Biblioteca Nacional do Brasil, do Rio de Janeiro, justificando a sua possível execução naquele território, para onde o artista se desloca a mando do então Príncipe Regente, imagens a fundamentar as palavras de Cyrillo, quando afirmava a "real munificência" e "protecção" dos monarcas, e a familiaridade de D. Carlota Joaquina com o universo cultural e artístico. Numa destas representações isentas de retórica áulica, ou simbólica régia, o artista retrata tão-só a "princesa-regente", enquanto pintora, apenas munida dos seus instrumentos para a prática artística.

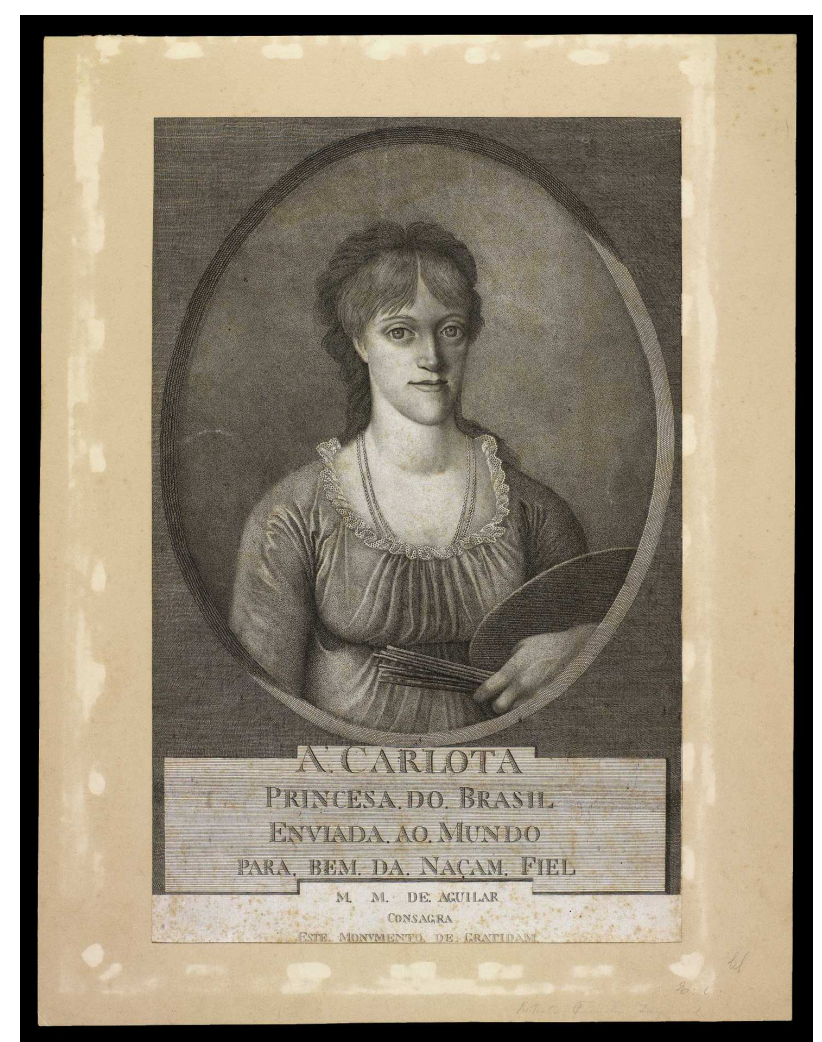

“À Carlota Princesa do Brasil enviada ao Mundo para bem da Naçam fiel. M.M. Aguilar consagra este Monumento de Gratidam". Aguilar, Manuel Marques de, (1767-1816), Curiosa representação da princesa que se oferece ao olhar do espectador de um modo despojado, tendo como única insígnia a da ligação ao universo artístico. Fundação Biblioteca Nacional do Rio de Janeiro ${ }^{220}$.

${ }^{220}$ http://objdigital.bn.br/acervo digital/div iconografia/icon551656/icon551656.html. Consulta online Dezembro 2018. 
A legenda "À Carlota Princesa do Brasil enviada ao Mundo para bem da Naçam fiel. M.M. Aguilar consagra este Monumento de Gratitude", é um testemunho público de gratidão do artista à Princesa, que surge empunhando uma paleta e pincéis. Isto é, Aguilar transformou o retrato numa alegoria às qualidades artísticas da representada, omitindo quaisquer atributos áulicos.

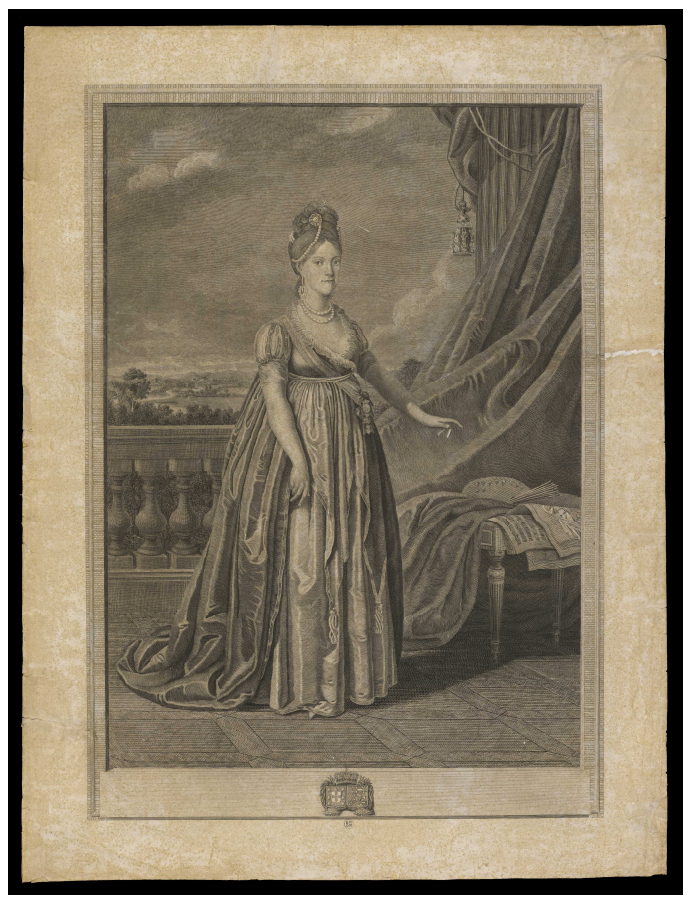

Retrato D. Carlota Joaquina, Aguilar, Manuel Marques de, (1767-1816). Ver o detalhe do gesto retórico de D. Carlota Joaquina, apontando para um conjunto de símbolos artísticos, tais como pautas musicais, desenhos, paleta e pincéis, dispostos sobre uma banqueta. Fundação Biblioteca Nacional do Rio de Janeiro 221 .

Em uma outra gravura, a então Princesa do Brasil, num gesto retórico, aponta com a mão esquerda, para um conjunto de símbolos tais como pautas musicais, desenhos, paleta e pincéis, alusivos às diversas artes - a música, o desenho e a pintura, dispostos sobre uma banqueta, o que se afigura como uma inovação compatível com a centralidade que o culto da arte adquiriria no século XIX.

Há algo de coloquial proximidade nestes retratos que nos devolvem o retrato humano da régia mecenas, constituindo, em simultâneo, um testemunho da gratidão àquela que patrocionava o artista, sendo, em consequência, documentos de grande relevância, pela informação que veiculam.

\footnotetext{
${ }^{221} \mathrm{http}: / /$ objdigital.bn.br/acervo digital/div iconografia/icon106603.htm. Consulta online Dezembro de 2018.
} 


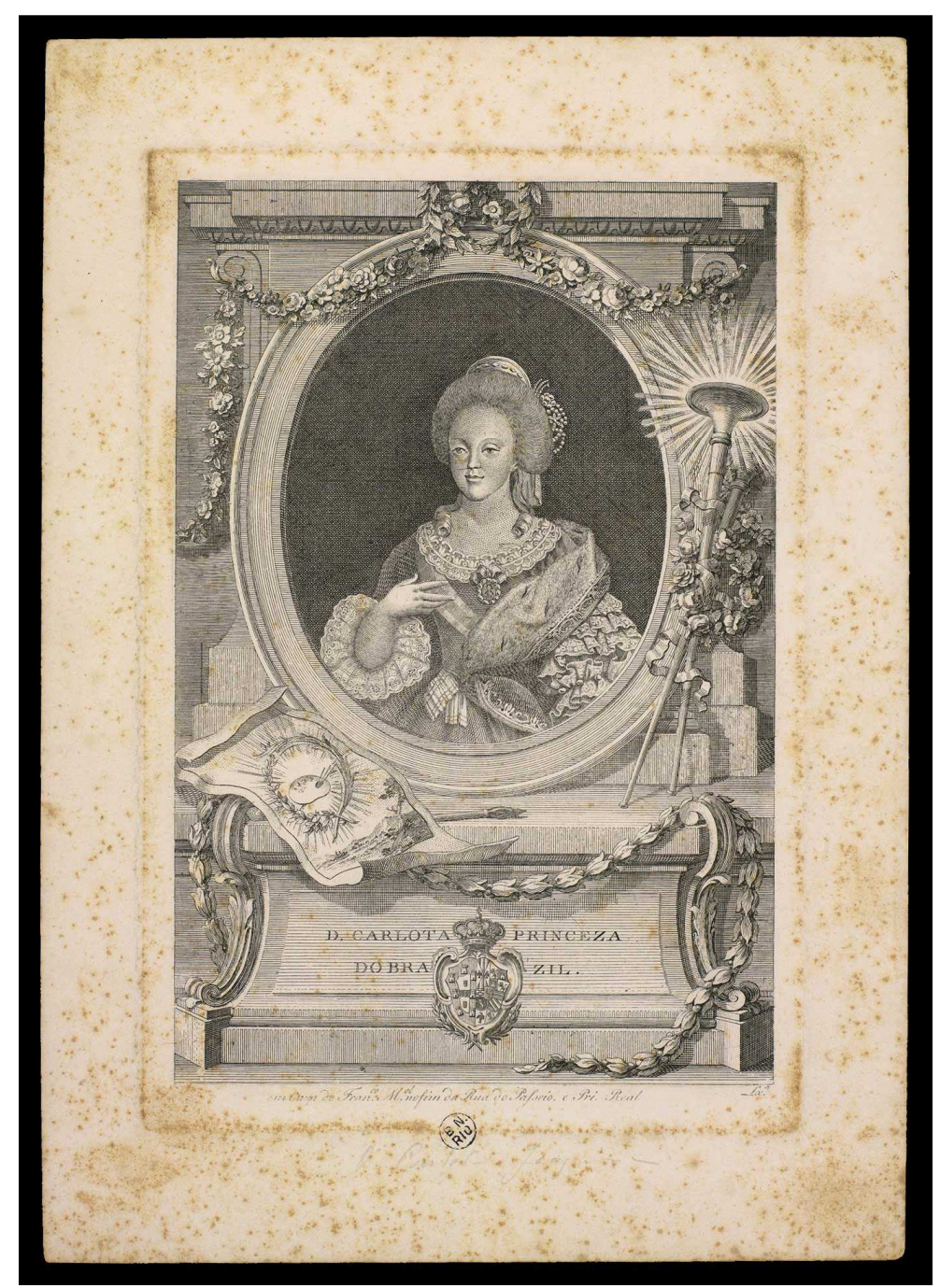

“D. Carlota Princeza do Brazil”. Fundação Biblioteca Nacional do Brasil. A gravura não apresenta autoria, nem data. Um facho de luz ilumina a composição, no lado direito, enquanto do lado esquerdo da gravura se apresenta uma paleta e pincéis dentro de uma grinalda de flores ${ }^{222}$.

A ligação de D. Carlota Joaquina ao universo artístico fica, assim, atestada por diversa iconografia. Uma outra gravura tem, para o estudo que efectuamos, especial significado, pois representa o tributo de um dos mais talentosos pintores portugueses, isto é Francisco Vieira Portuense (1765-1805), à então Princesa do Brasil. Trata-se da gravura que integrava as coleções do Ramalhão e que surge no lote com o n. 157, do catálogo do leilão da Bemposta, descrita como "Sacra Família [...] invenção de Vieira Portuense gravada por Queiroz"223, e que, como mencionamos, cremos seja a "Sagrada Família", descrita por Ernesto Soares como uma "Sagrada Família - Cena passada nas margens de um rio. A Virgem Nossa Senhora está em pé na proa de um barco, onde se vêem S. José e o Menino Jesus que levanta os braços para um grupo de anjos que, entre nuvens, transportam enorme Cruz. O barqueiro segurando a vara,

${ }^{222}$ http://objdigital.bn.br/acervo digital/div iconografia/icon106618.jpg. Consulta online Julho de 2018. 223 Integrava um conjunto de cinco gravuras com o n.o 157 e foi adquirida pelo Sr. D. José Maria da Costa Silveira da Motta, no dia 19 de Junho de 1848. ANTT, Casa Real, Cx. 7311, maço 91. V. Nota 210. 
está de pé em atitude de quem sustém o barco, esperando que a Senhora ocupe o seu lugar. Na margem oposta recorta-se pitoresca paisagem" [...]"224. Nesta se inscreve na parte inferior: "Dedicada a S.A.R. a Princeza do Brazil Nossa Senhora por F. Vieira Port. Pintor de Hist. Penc.de S.M.F. London Published as the Act directs Jan. A. 1799. Subs - Poussin inv.t F. Vieira Portoense del. et sculp.em 1799". Obra subscrita pelo autor, segundo Ernesto Soares, única obra de Vieira com esta temática. Não logramos localizar esta gravura em nenhuma instituição.

Em um dos Álbuns de desenho de Francisco Vieira Portuense que se encontram no Museu Nacional de Arte Antiga, Lisboa, verificamos que o desenho a lápis, n.o inv. 817/54 Des. MNAA, denominado $O$ Regresso do Egipto, representa exactamente a cena descrita por Ernesto Soares e que, consideramos, poderá ter servido de modelo para aquela obra gravada, dedicada por Vieira à então Princesa do Brasil.

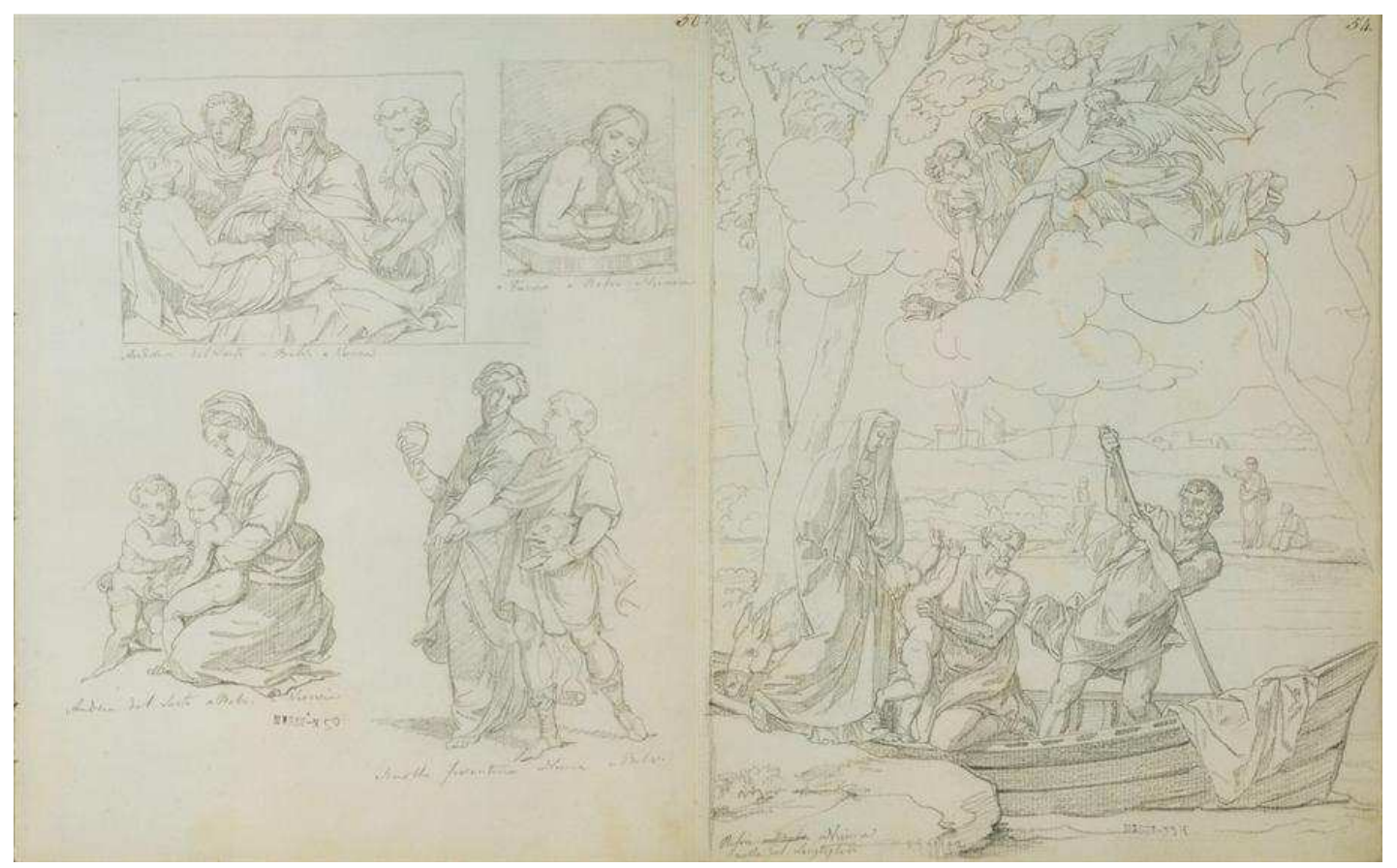

Álbum de desenhos de Francisco Vieira Portuense, entre eles, A Virgem, o Menino e S. João Baptista, inv. 817/50 MNAA; e O Regresso do Egipto, desenho a lápis, inv. 817/54 Des. MNAA. Este desenho reproduz a descrição apresentada por Ernesto Soares para a gravura que Vieira dedica a D. Carlota Joaquina A Sagrada Família pelo que deve ter servido de base para a execução da mesma.

A ligação ao universo cultural é de igual modo testemunhada por dedicatórias que lhe são dirigidas por escritores e escritoras, tema que será tratado autonomamente.

224 SOARES, Ernesto, História da Gravura Artística em Portugal, Lisboa, 1940. V. Tomo I, p. 651, com N.은 2198. 


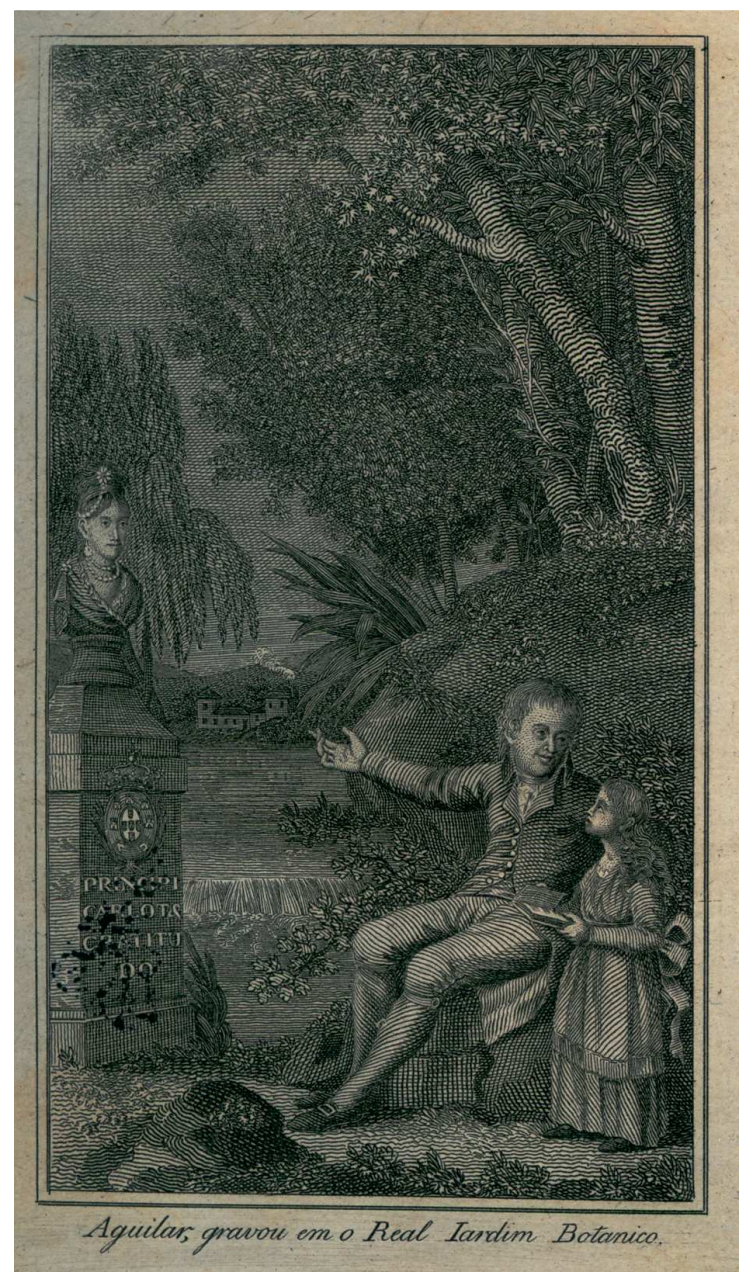

"Aguilar gravou em o Real Jardim Botânico", in folha de ante-rosto, Lições de hum Pay a huma filha sua, na primeira idade, Roque Ferreira Lobo, Na Regia Officina Typographica, Lisboa, 1803, BA 68-II-43. Na gravura uma figura masculina, olhando para uma menina, com o braço direito aponta para uma escultura, de figura semelhante às representações de Aguilar sobre D. Carlota Joaquina, na base da qual se pode ler "Principi Carlot\& Gratitu do".

\section{V.I - D. Carlota Joaquina, pintora}

Observamos o que poderíamos considerar como uma biografia passiva elaborada por pintores e gravadores, através das imagens com as quais representam a então Princesa do Brasil, futura Rainha de Portugal, todas remetendo para o facto de ela própria ser praticante da arte da pintura.

A prova material encontra-se nas colecções do Palácio Nacional da Ajuda. Isto é, uma pintura a óleo sobre tela, Figura Popular, pintada por D. Carlota Joaquina, em 1795, figura singular, retrato não idealizado, desenhado com um traço expressivo e seguro, a justificar as palavras que Ihe dedicou Cyrillo Wolkmar Machado (1748-1823), quando afirmou "He bem sabido de todos o raríssimo talento que tem a Rainha a Senhora D. Carlota Joaquina, para as sciencias, $e$ bellas Artes. Com poucas lições fez grandes progressos no desenho, e pintura de óleo, e de 
pastel, e senão executou muitas obras desta natureza, foi porque empregava o tempo ainda melhor na excelente educação que soube dar às suas Augustas Filhas, que também aprenderão a desenhar $[\ldots]^{\prime 225}$.

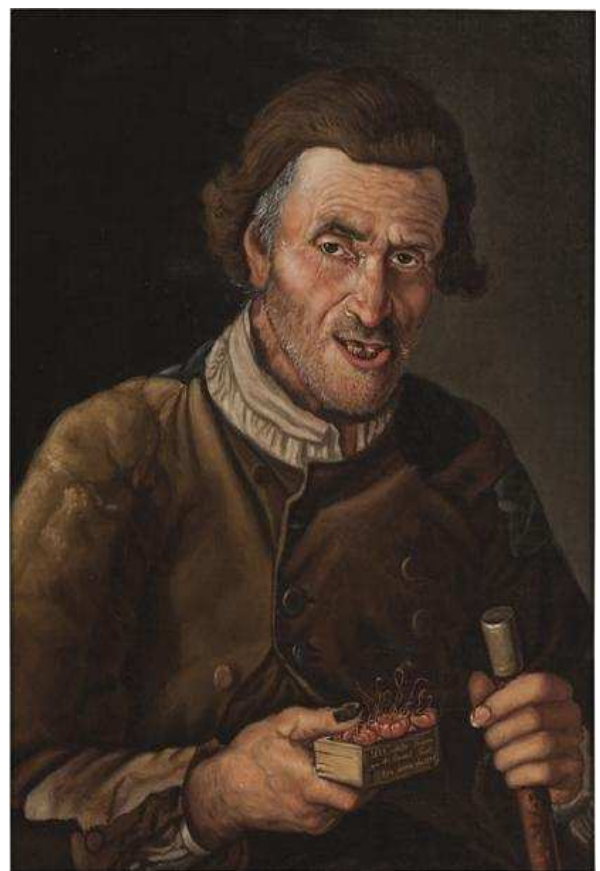

Figura Popular, 1795, Palácio Nacional da Ajuda, inv. N.ㅇ 2930, óleo sobre tela. Autor - D. Carlota Joaquina de Bourbon. Esta é uma das várias pinturas que existiam no Palácio da Ajuda, da autoria de D. Carlota Joaquina. A atenção ao quotidiano que a rodeia revela-o a Princesa, enquanto artista, na pintura naturalista, de costumes, de um personagem popular 226

De acordo com Ayres de Carvalho 227 , encontravam-se ainda no Palácio da Ajuda outras pinturas da autoria de D. Carlota Joaquina, tendo ardido no incêndio da Galeria do Rei D. Luís, em 23 de Setembro de 1974, duas telas, "uma representando uma mulher do norte de Espanha, com "montera em forma de capacete pontiagudo" 228, "e outra pintada sobre chapa

225 WOLKMAR Machado, Cyrillo, Colecção de memorias relativas as vidas dos pintores, e escultores, architectos, e gravadores portuguezes, e dos estrangeiros que estiverão em Portugal, recolhidas $e$ ordenadas por Cyrillo Volkmar Machado [...] Lisboa. Na Imp. de Victorino Rodrigues da Silva, 1823, p. 30. D. Carlota Joaquina tivera nove filhos sendo a primogénita a infanta D. Maria Teresa, nascida em 1793. Em 1795, nasceria o infante D. António, herdeiro do trono, que morreria menino, aos sete anos de idade. Seguir-se-iam D. Maria Isabel, em 1797, que seria rainha de Espanha, antes de uma morte prematura, ficando ainda assim ligada à criação de um Museu de Belas Artes de Madrid, D. Pedro, futuro Imperador do Brasil, a Infanta D. Maria Francisca, D. Isabel Maria, em 1801, que viria a ser regente por indicação de seu pai, D. Miguel, em 1802, aliado de sua mãe nas fileiras absolutistas, D. Maria da Assunção, em 1805 e D. Ana de Jesus Maria, em 1806.

${ }^{226}$ http://www.matriznet.dgpc.pt/MatrizNet/Objectos/ObjectosConsultar.aspx?ldReg=991070. Consulta online Janeiro de 2019.

227 CARVAlHO, A. Ayres de, "A Galeria de Pintura da Ajuda e as Galerias do século XIX", in Revista e Boletim da Academia Nacional de Belas-Artes, Lisboa 1981, 3. Série n. 3, p. 24.

228 PNA, inv.o 41455 (X" 612 Arrol. PNA). 
de cobre com a figura de S. Francisco, as mãos cruzadas sobre o peito e assinado: D. Carlota Princeza do Brasil Pintou em 1796, Med.A. 0,41- L.0,34"229.

A abertura de espírito e curiosidade intectual que faziam D. Carlota Joaquina desdobrar-se em inúmeros interesses, da prática artística à leitura, ficou testemunhada na diversidade de livros que reuniu na sua Livraria, do coleccionismo científico, ao artístico que se traduziu na presença no seu "Gabinete" de pintura de uma pluralidade de géneros e temáticas, de épocas e estilos distintos, das Naturezas Mortas tão ao gosto da cultura espanhola de seiscentos, à pintura religiosa, reflexo da centralidade das práticas devocionais da Europa Católica de Antigo Regime, dos temas da mitologia clássica, caros à cultura iluminista, às paisagens a reflectirem um gosto pela natureza, tão de acordo com a cultura pré-romântica e romântica que se anunciava; dos pintores de épocas passadas, aos seus contemporâneos que apoiou enquanto monarca ilustrada.

A formação e educação que a Rainha de Portugal soube dar às suas filhas, a "excelente educação que soube dar às suas Augustas Filhas, que também aprenderão a desenhar [...]", enaltecida por Cyrillo e pelo embaixador de Espanha, reconhecem-na actualmente o meio académico e museológico espanhol, ao atribuir a sua filha D. Maria Isabel (1797-1818), Rainha consorte de Espanha, a iniciativa de reunir obras de arte das colecções régias de Espanha, para a formação de um Museu, que está na origem do Museu do Prado, em Madrid, de que actualmente se celebra o duplo centenário.

A imagem traçada por Cyrillo é, aliás, corroborada pelo Embaixador de Espanha, na corte do Rio de Janeiro, o 1. Marquês de Casa Irujo, que vários autores citam ${ }^{230}$, o qual refere, em carta dirigida ao Governo de Espanha, datada de 1810, que D. Carlota "se impone com facilidade en los Negócios, los conoce, y gusta ocuparse de ellos, dedica diariamente varias horas al Gavinete, sin descuidar la educación de su numerosa familia de que puede Ihamarse la primera aya: tiene ideas corretas sobre assumptos cuyo conocimiento es poco común en su sexo y es religiosa sin superstición".

\footnotetext{
229 PNA, inv.o 41456. Conforme Arrolamento do Palácio, esta pintura teria, em cima, à esquerda, uma etiqueta com o n.o 391 e, à direita, uma outra com a inscrição: "1 lote de seis quadros". http://www.matriznet.dgpc.pt/MatrizNet/objetos. Consulta online Março de 2019.

${ }^{230}$ SARDINHA, António, Ao Princípio era o Verbo, Ensaios e Estudos, Livraria Portugália, Lisboa, 1924, p. 344; PEREIRA, Sara Marques, D. Carlota Joaquina Rainha de Portugal, Livros Horizonte, 2. a edição, Lisboa, 2008, p. 31.
} 


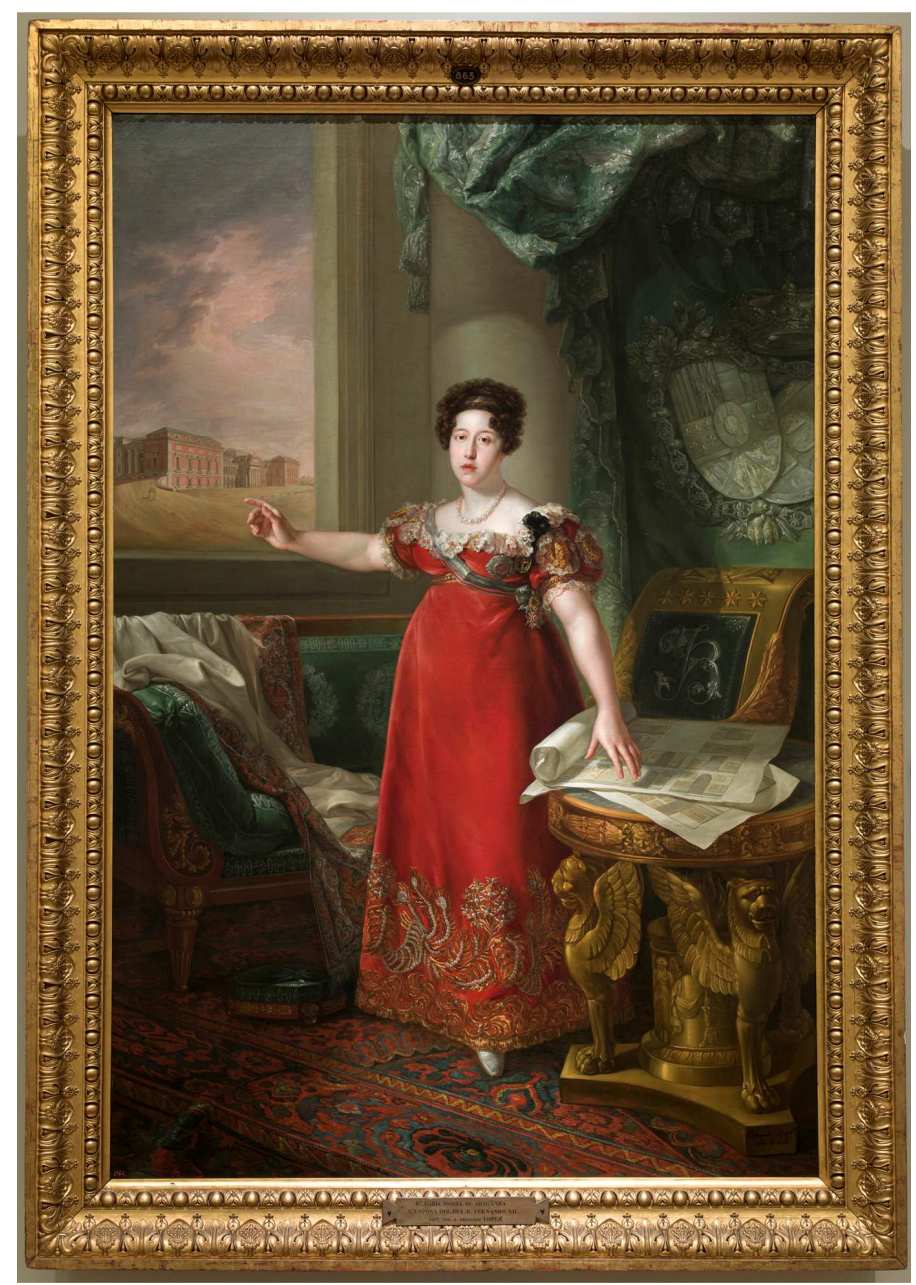

D. Maria Isabel de Bragança, Rainha de Espanha, como fundadora do Museu do Prado, Bernardo López Piquer, Madrid, 1829. Obra póstuma. Coleção Real, Museu do Prado, Madrid. Na ficha de catalogação do Museu pode lerse: "Isabel de Braganza era aficionada a las bellas artes, practicaba la pintura, era académica de honor y consiliaria de la Real Academia de Bellas Artes de San Fernando, y mantuvo un gran interés en el proyecto de convertir el edificio de Juan de Villanueva, destinado en origen a albergar un Gabinete de Ciencias Naturales, en museo de arte. Pedro de Madrazo, en el catálogo de los cuadros del Real Museo de 1854, llega a decir que fue la reina quien sugirió la idea [al rey], por escitacion [sic] de algunos personajes aficionado a las nobles artes, y el Rey la acogió con verdadero entusiasmo. Con su mano izquierda señala unos planos extendidos sobre el velador de leones alados. [...] aquí lo que está representado son alzados de las salas con la colocación de los cuadros. Seguramente hay que interpretar este detalle como testimonio de un interés bastante más que superficial de la reina por la museología del Prado. Desafortunadamente, no llegó a presenciar la inauguración del Museo, que tuvo lugar casi un año después de su prematuro fallecimiento" 231.

Assim, tanto as imagens literárias como as pictóricas, deixadas por contemporâneos, abrem o caminho para o questionamento do discurso historiográfico que os séculos XIX e XX elaboram sobre as personagens régias de D. Carlota Joaquina e D. João VI, derradeiras figuras reinantes do regime absolutista. O confronto entre aquelas imagens e o papel desempenhado por ambos, no campo da cultura, na sociedade portuguesa e brasileira, atestado nos seus actos, fazem de grande actualidade as palavras de Paulo Varela Gomes "Cremos que chegou a altura

\footnotetext{
231 Coleç̧ão Real, Museu do Prado, Madrid, no cat. Pooo863.

https://www.museodelprado.es/coleccion/obra-de-arte/maria-isabel-de-braganza-como-fundadoradel-museo/a7a1a933-6dc5-4636-b963-224d42e77110?searchid=c5ebfa89-4913-c501-d6f444ad3af8c554. Consulta online Agosto de 2019.
} 
de reavaliar o papel de patrono desempenhado pelo Rei D. João VI (o mais retratado dos monarcas portugueses e não por acaso) e de indivíduos como Pina Manique, Alexandre e Sousa e Holstein e seu filho Pedro, 1ㅇ Duque de Palmela, o bispo do Algarve Gomes de Avelar [...], D. Rodrigo de Sousa Coutinho, D. João de Almeida Melo e Castro"232, entre outros que nomeia, curiosamente todos masculinos, confirmando a dupla dificuldade da abordagem ao universo feminino, ou ao papel das mulheres nestes domínios, que se desenvolviam, essencialmente, no domínio privado.

232 GOMES, Paulo Varela, "Correntes do Neoclacissismo Europeu na Pintura Portuguesa do século XVIII", Sep. do IV Simpósio Luso-Espanhol de História da Arte. Portugal e Espanha entre a Europa e Além-Mar, Instituto de História da Arte, Fac. Letras, Universidade Coimbra, 1988, p. 481. 


\section{VI — Do Brasil a Lisboa. Chegadas. O regresso a Casa}

\section{VI.I - Chegadas. O Regresso}

Com o regresso da família real do Brasil, em 1821, cessam as fontes epistolares e as notícias sobre o Palácio do Ramalhão rareiam, até às vésperas da morte da sua proprietária e ao inventário elaborado poucos meses antes - "Inventário das Preciozidades, Joias, Alfaias e mais pertences existentes na Quinta do Ramalhão em Setembro de 1829"233 - documento de enorme importância para o conhecimento dos interiores daquele Paço, e das alterações ali ocorridas, após o regresso da família real do Rio de Janeiro.

O inventário de 1829 segue, tal como o anterior, datado de 1807 - "Inventário de toda a Mobília que existe no Real Paço do Ramalhão da Princeza N.Snr. a feito em Julho de $1807^{\prime 234}$, a descrição por salas, identificando todos os móveis alocados em cada espaço, prestando-nos importantes informações quanto às transformações ocorridas no Ramalhão, na sequência da recusa de D. Carlota Joaquina prestar juramento da Constituição, em 1822, e dos acontecimentos políticos de 1823 e 1824, e da sua permanência naquele local, onde the fora fixada residência, por temporadas ${ }^{235}$. 0 protagonismo que assumiu naquela conjuntura, 0 apoio, mais ou menos declarado, aos movimentos contra-revolucionários e conspirativos, marcaram a sua "lenda" e a História de Portugal, daquele período, em que para o sector conservador e absolutista foi uma "divindade tutelar", enquanto para os constitucionalistas, uma perigosa conspiradora. Na literatura de então alinhavam-se, do lado onde se posicionava D. Carlota Joquina e o seu filho D. Miguel, os defensores do trono e do altar, o sector tradicionalista que definia o lado liberal, opositor, como o dos "afrancesados", "jacobinos" e "maçónicos", que muito contribuiriam para a construção das imagens que constituiriam, doravante, uma "lenda negra" associada à soberana e que perduraria, longamente, no imaginário nacional.

A livraria de D. Carlota Joaquina demonstra-nos como a soberana se interessara pelas correntes filosóficas e culturais que sustentavam os seus pontos de vista, dispondo de obras de inúmeros autores que, se conservadores do ponto de vista político, tal como François-René Chateaubriand (1768-1884), abriam vias de pensamento fundamentais para a eclosão do

\footnotetext{
${ }^{233}$ ANTT, Casa Real, Cx. 3703.

${ }^{234}$ ANTT, Casa das Rainhas, Livro 234.

${ }^{235}$ V. a este propósito a muito interessante biografia traçada por PEREIRA, Sara Marques, D. Carlota Joaquina Rainha de Portugal, Livros Horizonte, 2. a edição, 2008, Capítulo IV, "Do Degredo ao Paraíso A Actuação Política em Portugal (1821-1830)", pp. 129-171. Trata-se, a nosso ver, da obra mais completa e bem documentada sobre a soberana portuguesa elaborada na actualidade.
} 
movimento romântico, que dominaria a cultura de oitocentos. De igual modo, leu e conheceu a literatura e os autores que defenderam uma mundivisão com a qual não comungava. Lá encontramos o Contrato Social, de J. J. Rousseu, com o superlibros de D. Carlota Joaquina, e muitos outros autores que tinham integrado o "Catalogo de livros defesos neste Reino [...]"236, interditos pela censura. Essa abordagem não é, no entanto, o foco deste capítulo, pelo que a sua exploração será continuada futuramente. A actividade política da rainha portuguesa foi intensa, por aqueles tempos, e o Ramalhão, o centro de encontros, um dos lugares de residência e de resistência aos ecos liberais.

Depois do regresso. Uma primeira observação do inventário de 1829 permite-nos verificar diversas alterações, de entre as quais a relativa aos aposentos anteriormente destinados a D. Maria I, que morrera no Brasil em 1816. Estes passam a ter outra funcionalidade, pois neles já não detectamos referência a camas. Nos anexos ao quarto anteriormente mencionado como da então Princesa do Brasil, eventualmente reservados ao alojamento das infantas, suas filhas, são agora assinaladas, modificações que podem ser consequência dos casamentos, em Espanha, de D. Maria Isabel (1797-1818) e de D. Maria Francisca de Assis (1800-1834), com os seus tios, respectivamente, Fernando VII (1784-1833) e seu irmão Carlos Maria Isidro (1788$1855)$, realizados no ano de $1816^{237}$.

No que respeita a anteriormente denominada, "Camara da Princeza N.Sr.a N.3", deixa, de igual modo, de existir a referência a camas, apresentando o inventário de 1829, para aquele espaço, apenas a presença de cómodas, cadeiras e escrivaninha de mogno, pelo que os aposentos de D. Carlota Joaquina deverão ter mudado para uma zona mais interior da casa, passando a ocupar, julgamos, a anterior "Sala N.o 6", de maior dimensão, pois nela agora encontramos "Duas camas de Sicupira de Armação", "Dois Escaparates de Mogno com pedras pretas", "Hum altar portátil de Espinheiro com a firma de Sua Magestade gravada em prata e pedra Ara quatro Frontais Trez Cazulas [...] Huma Picede de prata", objecto que deve ter substituído o

\footnotetext{
236 "Catalogo de livros defesos neste Reino, desde o dia da Criação da Real Mesa Cençoria athé ao presente. Para servir no expediente da Caza da Revizão (1768-1814)"236, Coleç̧ão Real Mesa Censória, Livro n.o 811, ANTT, in Boletim da Biblioteca da Universidade de Coimbra, Vol. XXVI, Coimbra, 1964, pp. 118-207. BA. 152-XV-13.

${ }^{237}$ V. a este propósito o texto relativo às compras efectuadas por D. Carlota Joaquina através do seu emissário Juan Baptista Ardisson, no ano de 1816, pelas quais aquele reclamava dos pagamentos. In blog da Biblioteca da Ajuda - Factura de los acopios q.o Dn. Jn. B.ta Ardisson ha hecho en Paris p. $\underline{\text { Ia }}$ Guarda Ropa de S. M. M. Ia Reyna N.S., y Sr. Infanta D. M. $\underline{a}$ Franc. $\underline{a}$ de Asis. Paris 1816. 4ㅇ \&. Este manuscrito fazia parte da Livraria da Rainha D. Carlota Joaquina (BA 51-XIII-7), não tendo, no entanto, sido localizado na Biblioteca da Ajuda. Foi recentemente adquirido, no mercado, pela Parques de Sintra Monte da Lua, para o Palácio Nacional de Sintra. Ver blog Biblioteca da Ajuda.
} 
anterior de invocação a Santo António, levado pelos franceses, segundo João dos $\operatorname{Santos}^{238}$, "Huma Livraria de mogno guarnecida de bronze com portas de Espelhos"239. A 5. a Sala que a antecede dispõe de "Huma Marqueza piquena de Armação", "Huma Meza piquena de espinheiro com abas", bem como o sempre presente conjunto de canapé e cadeiras, pelo que deveria cumprir as funções de uma antecâmara de apoio ao serviço da agora Rainha, e a 7.a Sala que sucede à Camara, apresentando "Dois Espelhos de Mogno guarnecidos de bronze que servem de vestir", duas cómodas, seis cadeiras e um canapé, o tremó "guarnecido de bronze" com o seu espelho e pedra branca, serviria agora de quarto de vestir. A 8. - Sala, no anterior inventário classificada como "Camarim", surge, no inventário de 1829, como dispondo de "Duas cadeiras de Retrete forradas de Amarello", de "Dois Pez de Tremo de Mogno guarnecidos de bronze e pedras brancas", significando que continuava a ser um espaço reservado à intimidade e que o quarto de D. Carlota Joaquina teria absorvido uma maior área, agora com quatro compartimentos, ficando mais afastada da zona de dormir, o espaço dedicado à retrete.

Para além deste conjunto destinado ao uso privado, encontramos outro, de igual conformação, nos espaços que sucedem às salas de maiores dimensões. Assim, só na 17. a Sala surge, de novo, a referência a uma cama - "Huma cama de Páo Santo doirada", "Hum Escaparate do d. huma Meza de Jogo fulhiada", os objectos para a higiene - "Huma Agoa às mãos guarnecido de Bronze com Espelho e Pedra azul [...]", para além das "seis cadeiras e hum Canapé de Mogno com assentos e Costas de Pano bordado a ruinadas da traça"240.

Assim, à eventual alteração no que respeita a localização do quarto de D. Carlota Joaquina, podemos associar outras que se relacionam com mudanças de funcionalidade dos espaços, eventualmente decorrentes do menor número de familiares directos agora presentes na corte lisboeta.

\footnotetext{
238 Declarações de João dos Santos aquando da passagem de testemunho para o Almoxarife que o substituirá “Declaraçoens [...]”, Arquivo Museu Imperial Rio de Janeiro, I-POB-00.07. 1807. V. nota 123. ${ }^{239}$ As referências a estantes para livros, ou armários para aquele efeito, não parecem ser de molde a poder acolher a quantidade de livros que integra o catálogo da livraria de D. Carlota Joaquina, pelo que somos da opinião de que, eventualmente uma parte, correspondente aos livros que vieram do Brasil, tivesse sido acomodada nos espaços da antiga livraria do Paço Real da Ajuda. V. ANTT, Casa Real, Cx. 6523 , documento relativo aos móveis que ficaram no Ramalhão e que nomeia estantes.

${ }^{240}$ ANTT, Casa Real, 387, Cx. 3703.
} 
Uma referência que não constava no inventário de $1807^{241}$, relaciona-se com a colecção de relógios que agora constituem um item autónomo, nele sendo contabilizados vinte e um exemplares que vão do "Relógio de Sol de Bronze doirado com huma pessa de Artilharia", ao de "Bronze doirado com huma figura" à frente do qual o inventariante escreveu "lindo", "Outro de bronze doirado que forma huma gaiola e em sima trez figuras", "hum d.o em sima de pedra preta Carro de Dianna puxado a dois Galgos de bronze doirado", "outro do de Bronze doirado figura de Minerva", entre muitos outros.

VI.II - A Música. Uma modificação, significativa para o nosso estudo, relaciona-se com a anteriormente denominada "Caza da Pintura no 9", pois neste último inventário de 1829, aquela sala perde a anterior denominação, passando a figurar apenas como "9a Salla", contendo, para além das mesmas doze cadeiras, antes "cadeiras douradas com assentos estofados", agora de "pao Santo com braços e assento de palhinha guarnecidas de latão", e de "hum tremó de mogno com hum Realejo fingindo Cascata guarnecido de bronze", bem como "duas Bacias da Indía grandes com pez de páo", constatamos agora a presença de diversos instrumentos musicais, não surgindo qualquer menção à existência de pintura.

Aquela era agora, claramente, uma sala destinada à música, pelo conjunto apreciável de instrumentos de corda, aí reunidos, tais como: "Hum cravo de pernas", "Hum Forte Pianno" e "Huma Arpa", o que se conjuga bem com a centralidade que a música detinha nas práticas artísticas e sociais, na corte brigantina, confirmada em inúmeros relatos e memórias, que vão de W. Beckford, ao Marquês de Fronteira, D. José Trazimundo Mascarenhas ${ }^{242}$, que descreve os saraus musicais na corte lisboeta, nos quais, elementos destacados da aristocracia, tomavam parte. O facto de João Domingos Bomtempo (1775-1842) ter dedicado a primeira composição que publicou, uma sonata, a D. Carlota Joaquina, com o seguinte título: Grande Sonate pour le Piano Forte, composée et dediée à Son Altesse Royale La Princesas de Portugal, par J. D. Bomtempo, pode ser revelador de algum papel desempenhado pela então Princesa do Brasil no apoio a um dos maiores compositores portugueses de todos os tempos.

VI.III - A "Casa de Arrecadação". Outro dado surpreendente relaciona-se com uma denominada "Caza de Arrecadação", que neste inventário, sucede imediatamente após as "Caza dos Armarios" e "Caza do Jantar", que continuam a ocupar os espaços na extremidade

\footnotetext{
241 ANTT, Casa das Rainhas, Livro 234.

${ }^{242}$ Memorias do Marquez de Fronteira e d'Alorna, Imprensa Nacional-Casa da Moeda, vols. I-II, 1986, p. 230. Edição fac-similada da Imprensa da Universidade de Coimbra, 1928.
} 
do corpo sul do edifício. Naquele espaço de arrumos, que eventualmente se localizaria no piso inferior, o inventariante identifica "hum Palacio Chinez de Marfim"243, que na relação de 1807 era apresentado na "Salla da Entrada №1", e na de 1816 dizia João dos Santos "Existe desarmado", mas não declarava onde, "Duas embarcações de Marfim", "Hum Presepio de Marfim", "hum Toucador de Tartaruga guarnecido de Mádreperolla com a firma de Sua Magestade"244, "Quatro Imprensas - huma de Roupa", "Trez Globos hum Celeste e dois terrestes”, “Doze Mappas em Papel”, “Onze Armários de Vinhático”, inúmeros outros objectos e móveis, para além de cobertas, cobertores, mesas e cadeiras de todas as espécies e, surpreendentemente, pinturas - "Hum quadro de moldura doirada com bambuxata de Macacos", e "Oitenta e hum Paineis com diferentes pinturas - Oitenta e cinco ditos moldura preta", e os já mencionados "trinta e hum quadros muito danificados pertencentes ao Mozeu - trez Maquinetas de Vidro com pássaros dentro pertencentes ao mesmo", bem como "Quatro figuras de Marmore que representa as quatro Estaçoens do Anno", "Quinze molduras de pao Santo", "Quarenta e duas Estampas em Papel", "Dois Retratos com molduras doiradas" $[\ldots]^{245}$. Quanto às figuras de mármore, num documento relativo aos objectos que ainda estariam no Ramalhão e que deveriam ser levados para a Bemposta surge, à frente, manuscrito, "Belém"246, pelo que aquelas deverão ter sido levadas para o Palácio de Belém, escapando ao destino da almoeda, e que, presumimos lá se encontrem, na actualidade.

De acordo com este inventário, de $1829^{247}$, estariam as pinturas anteriormente localizadas na “Caza da Pintura №9", reunidas na agora denominada "Caza de Arrecadação", por uma razão que não conseguimos esclarecer. Teriam, no regresso de Queluz, para onde foram desviadas em 1808, estando já a Princesa D. Carlota no Brasil, sido recolhidas naquela arrecadação, onde o diligente João dos Santos procederia a reparações? Em 1812, na sequência dos desmandos praticados pelos ocupantes franceses, João dos Santos informava a Princesa que já tinha "arranjado os quartos todos, esta pinta [sic] de novo pelo Manoel da S. a a sim como todo o Paço; e os trastes estão também arranjados e mto bonitos ahinda estão em caxotados"248. Em 1813 , voltava a fazer o ponto da situação quanto às obras a que ia procedendo, e aos arranjos e reparações, comentando, na carta de 5 de Outubro que "[...] a Pintura esta concervada, so

\footnotetext{
243 O que já referimos, actualmente no Palácio Nacional de Sintra.

${ }^{244}$ Considerando que encontramos referência a dois toucadores com a mesma descrição na colecção de D. Carlota Joaquina este pode corresponder ao que foi leiloado e, o outro, ao que se encontra em Queluz.

245 ANTT, Casa Real, 387, Cx. 3703.

${ }^{246}$ Ver ANTT, Casa Real, Cx. 6523.

247 ANTT, Casa Real, Cx. 3703.

248 ANTT, Casa das Rainhas, Maço 241, n. 46, 1812.
} 
tem alguma danificação as Molduras, em razão inbraques mas Joze Joaq.m esta acabando de fazer os trastes q forão todos mudados e logo se entra com as Molduras q. andem ficar como V.A.R. espera vellas [...]"249.

Nas "Declarações" 250 que apresenta sobre o inventário de 1807, na passagem de testemunho, c. 1816, nada declara quanto à denominada "Caza da Pintura № 9", limitando-se a acrescentar à margem, "Uma pessa, o Palácio do Imperador da China hera da Casa №1", bem como "Um navio de Marfim veio de Queluz", o que significa a mudança dos objectos e a sua presença agora naquele espaço. Quanto às pinturas, em 1816, não declarada alterações. Apesar dos consertos e arranjos a que ia procedendo "José Joaquim", conforme carta acima mencionada, provavelmente efectuados em lugar distinto ao da anterior localização das obras, no andar nobre.

\section{IV - Mistérios do Ramalhão}

À falta de fontes específicas que nos permitam respostas objectivas, não podemos senão sugerir hipóteses de trabalho, colocando algumas questões suplementares:

- Teriam as pinturas cujas molduras necessitavam de conserto sido reunidas na "Caza de Arrecadação"? E teriam ali permanecido nos anos subsequentes ao regresso da família real do Brasil, em 1821? Ou as pinturas mencionadas no inventário de 1829, naquela "Caza", seriam, eventualmente, as danificadas com as deslocações para Queluz e regresso ao Ramalhão, às quais deveriam ser somadas as vindas, por herança, de Espanha? São perguntas para as quais não encontramos, por enquanto, respostas claras.

Assim, se aos 180 quadros mencionados no inventário de 1807 (168 pinturas, mais os 12 quadros de fructas da America), como constando na "Caza da Pintura №9", somássemos as 135 provenientes da herança paterna que teriam chegado cerca de 1828, alcançávamos a soma de 315 obras (ou 303 se excluirmos os quadros de fructas [...]). Ora, o número de pinturas guardadas no Ramalhão, na "Caza de Arrecadação", mencionadas no inventário de 1829, ou as leiloadas na Bemposta, rondam as 179 pinturas, relativas a 146 lotes.

Vejamos:

Na relação de $1807^{251}$, na "Sala da Pintura, n. 9" existiam:

71 quadros moldura doirada

\footnotetext{
${ }^{249}$ ANTT, Casa das Rainhas, Maço 241, n. 63, 1813.

${ }^{250}$ Arquivo Museu Imperial do Rio de Janeiro, I-POB-00.07.1807.

251 ANTT, Casa das Rainhas, Livro 234.
} 
97 ditos ditos de pau Santo

12 ditos com frutas da America em vulto,

O que equivale a 168 pinturas, mais os "12 ditos de frutas" do "Muzeu". Nas Declarações de João dos Santos relativas à sua passagem de testemunho para António Joaquim da Silva ${ }^{252}$, cerca de 1816, é confirmada para a mesma sala, o mesmo número de pinturas do inventário de 1807. Ou, pelo menos, nada é dito quanto ao número das mesmas, pelo que se presume da sua permanência.

Agora, na Relação de 1829, a única referência a pinturas é a relativa à "Caza de Arrecadação", onde se amontoava toda a sorte de outros objectos, não sendo, no entanto, nomeada a localização específica daquele espaço, no edifício, sendo ali identificados:

1 Quadro de moldura doirada com bambuxata de Macacos ${ }^{253}$

81 Painéis com diferentes pinturas -85 ditos moldura preta

31 Quadros muito danificados pertencentes ao Mozeu - 3 Maquinetas de Vidro com pássaros dentro pertencentes ao mesmo

15 molduras de pao Santo ${ }^{254}$

42 Estampas em Papel

2 Retratos com molduras doiradas ${ }^{255}$

Se excluirmos da soma os 31 quadros do "Mozeu" e as 3 maquinetas de vidro, bem como as molduras, e as 42 Estampas em Papel, no que respeita exclusivamente a pinturas alcançamos o número de 169 obras.

Naquele ano de 1829, era já certa a chegada do conjunto que integrava a "Tercera Division $[\ldots]^{256}$, composto por cento e trinta e cinco pinturas (cento e nove bons e medianos e mais vinte e seis "quadros separados por malos"), sendo aceite que estas obras provenientes de

252 Arquivo do Museu Imperial do Rio de Janeiro, I-POB-00.07.1807.

${ }^{253}$ Na Tercera Division surge com o n. 253, "Una Bambochada, si nombre de autor" que integrava o lote das pinturas melhores. No Catálogo do leilão da Bemposta, com o no 82, "uma Bamboxata", atribuída a "David Teniers (cópia de)" que julgamos ser a mesma já mencionada em uma relação de 1809, citada em PIRES, António Caldeira, História do Palácio Nacional de Queluz, Coimbra 1926, p. 317, portanto anterior à vinda do lote hereditário.

254 Podem ser as "15 molduras de pao santo maciço guarnecidas de fios brancos na frente" que foram vendidas na sessão do dia 20 de Junho de 1848, do leilão da Bemposta.

255 Na Tercera Division surgem com o n.o 60 "Retrato de Muger de media figura, por Georgion" (com um valor elevado) e com o no 110 "Retrato de una Duquesa de Medicis, de autor flamenco" que seria adquirido pela Academia de Belas Artes, com o título "Quadro representando uma Imperatriz Alemã" e que hoje integra acervo do Museu Nacional de Arte Antiga, n.o inv. 453 Pint, e que sabemos pela relação da Academia, tinha "moldura doirada". Para a Academia foram, igualmente adquiridos dois retratos masculinos "Um cavaleiro antigo, Escola Loilio", actualmente no MNAA, no inv. 465 Pint e "Um desembargador", pelo Cavalleiro Velasques", actualmente no MNAA, n.o inv. 466 Pint, ambos com molduras douradas, de acordo com aquela relação.

${ }^{256}$ BA ms. 54-X-33 (7). 
Espanha teriam, em parte, sido guardadas no Ramalhão, como se depreende do facto de ali constarem aquando do inventário realizado do espólio da Imperatriz-Rainha, para efeitos de partilhas, bem como da referência a ali se encontrar arrecadado "Hum celindro grande de pinho com doze palmos de comprido p. palmo e trez quartos de diâmetro, em que vierão de hespanha inrolados os quadros grandes" 257 .

A semelhança entre os títulos das pinturas provenientes de Espanha e alguns das constantes do catálogo do leilão da Bemposta assegura-nos que a maioria estaria no Palácio do Ramalhão aquando do inventário para aquele efeito. Mas, talvez não a totalidade.

No catálogo do leilão da Bemposta foram leiloadas 179 pinturas relativas a 146 lotes, assim decompostos:

- Paisagens marítimas e campestres - 32 lotes, significando 44 pinturas;

- Temática Religiosa - Antigo e Novo Testamento - 82 lotes, significando 96 pinturas;

- Pintura de Género- 14 lotes, significando 18 pinturas;

- Temática Mitológica - 7 lotes, significando 8 pinturas;

- Retratos -8 lotes, representando 8 pinturas;

- Temática Histórica - 3 lotes, representando 5 pinturas.

Foram ainda leiloados 35 lotes relativos a 137 estampas, e outros, com obras diversas tais como 7 lotes, relativos a esculturas e altos e baixos-relevos, 2 lotes de desenho, com 4 obras, bem como os relativos a pássaros embalsamados, aos bordados a seda, o do frontispício de um palácio com conchas, entre diversos outros lotes, compostos por objectos de ordem utilitária ${ }^{258}$.

Ora, se nos ativermos apenas à relação de 1807, a qual identifica 168 pinturas, e se a estas acrescentarmos as 135 provenientes da herança paterna, alcançaríamos 303 pinturas, o que é um número superior ao leiloado na Bemposta que, como verificamos, seria de 179 pinturas, relativas a 146 lotes.

\footnotetext{
${ }^{257}$ ANTT, Casa Real, Cx. 6523, "Rellação dos trastes e mais objectos q. ainda existem no Ramalhão e no Palacio de Cintra ao serviço de S. M. F. pertencentes ou não pertencentes à Herança". V. BASTOS, Celina, "Percurso de uma pintura", obra citada, 2014, p. 13.

258 "Relação dos Quadros pertencentes á Herança da Imperatriz Rainha a Senhora D. Carlota Joaquina de Bourbon, hoje existentes no Real Palacio da Bemposta, onde hão-de ser vendidos em hasta publica, perante o Juiz do respectivo Inventario [...] e que forão descriptos e avaliados pelos Senhores António Manoel da Fonseca, Lente de Pintura Histórica da Academia das Bellas Artes de Lisboa, e Luiz Tirinnanzi, Pintor restaurador de quadros [...], assinado pelo Solicitador da Caza Real, Francisco de Caldas Aulete, Lisboa, 1844.
} 
Decorre destes factos a conclusão de nem toda a pintura afecta às colecções de D. Carlota Joaquina ter sido dispersa naquele leilão, por se encontrar, eventualmente, em outras residências régias, que não no Ramalhão, escapando assim ao destino da almoeda. 
VII - Incorporações. O manuscrito da Biblioteca da Ajuda - "Tercera Division, Cuadros adjudicados a la Serenissima Señora Infanta de España Dona Carlota Joaquina de Borbon, Reyna Viuda de Portugal, por la Testamanaria de los Señores Reyes Padres, en el año de $1826^{\prime 259}$.

\section{VII.I - Os Manuscritos da Biblioteca da Ajuda. A herança paterna.}

Por morte dos soberanos seus pais, Carlos IV de Espanha (1748-1819) e Maria Luísa de Parma (1751-1819), ambas as mortes ocorridas no início de 1819, no exílio italiano, herdara D. Carlota Joaquina um conjunto importante de pinturas, a que alude aquele manuscrito da BA "Tercera Division", debaixo da rubrica "Cuadros adjudicados a la Serenissima Señora Infanta de España Dona Carlota Joaquina de Borbon, Reyna Viuda de Portugal, por la Testamanaria de los Señores Reyes Padres, en el año de $1826^{\prime 260}$ que nos elucida sobre a data em que aquele processo de definição dos lotes que compunham cada quinhão hereditário, teria ficado concluído, bem como os títulos e autorias das pinturas ${ }^{261}$.

O manuscrito da Biblioteca da Ajuda é datado de Madrid, dia 30 de Março de 1826 e assinado por Francisco Scarlatti de Robles, Sebastian Hurtado, Pedro de Vargas. O Duque de Montemar ${ }^{262}$ assinava "recivi [...] y alhagas y lo firmo", confirmando a recepção dos objectos que constituíam a quota hereditária de sua real representada.

Embora a morte dos reis Carlos IV e Maria Luísa de Parma tenha ocorrido em Janeiro de 1819, o processo de partilhas foi moroso, em resultado de vicissitudes várias que retardaram a entrega das pinturas aos seus destinatários. Isto apesar da pressa colocada no "Inventario" das 688 pinturas que constituíam a colecção pictórica de Carlos IV, em Roma, e que foi realizado em apenas vinte dias pelos dois pintores de câmara dos monarcas no exílio, Juan Antonio de

\footnotetext{
${ }^{259}$ Biblioteca da Ajuda ms. 54-X-33 (7).

260 BA, idem.

${ }^{261}$ CHECA, obra citada, 2011, pp. 231 e 234 descreve bem todo este processo; BASTOS, Celina, "Percurso de Uma Pintura", in Luca Giordano. Êxtase de São Francisco, Museu Nacional de Arte Antiga, Secretaria de Estado da Cultura, Março, 2014, p. 10.

262 António Maria Ponce de Leon y Dávila Carrillo de Albornoz (31.10.1757- 08.05.1826), 4.ํ Duque de Montemar e Conde de Garciez e de Valhermoso. Julgamos que se tratava de uma pessoa só, como representante de D. Carlota Joaquina, e não de duas, como refere Checa no seu estudo, pois a grafia irregular a fez considerar, a existência de um conde de Gámez que julgamos ser de Garciez, título que pertencia àquele Duque.
} 
Ribera (1779-1860) e José de Madrazo (178?-1859)263. Assim, segundo Checa, a 11 de Fevereiro de 1819, estava concluído o inventário das pinturas, bem como dos "melhores móveis que adornavam os palácios Barberini, Sant'Alessio e Sant'Albano", que aqueles monarcas ocuparam no exílio ${ }^{264}$.

Embarcadas com destino a Espanha, debaixo da custódia do pintor Ribera ${ }^{265}$, as pinturas chegaram ao Palácio Real de Madrid, a 8 de Fevereiro de 1820. Aí se deu início ao trabalho de avaliação, não só das pinturas, como das respectivas molduras, o que foi levado a efeito pelos mesmos pintores de câmara que os haviam inventariado em Roma. A avaliação, feita em reais e maravedis, estava terminada em 24 de Março daquele $a n o^{266}$, o que permitiu estabelecer os lotes destinados a cada um dos "Augustos coherederos".

No entanto, só alguns anos mais tarde, em Março de 1825, foi lida a respectiva execução da herança, da qual resultou que, de acordo com a "Tercera Division", foram adjudicados à "S.ra Reyna de Portugal"267, 135 obras cuja lista é apresentada - "Cuadros adjudicados a la Serenissima Señora Infanta de España Dona Carlota Joaquina de Borbon, Reyna Viuda de Portugal, por la Testamanaria de los Señores Reyes Padres, en el año de 1826". A pintura era avaliada em 202.920 reais, as "joyas" que igualmente faziam parte do lote valiam 786.341 reais, cabendo ainda um montante em metálico. Assim, de acordo com o manuscrito da Biblioteca da Ajuda, couberam à Rainha de Portugal, por partilha, os seguintes valores, contemplando a dedução da terça parte, conforme expressa o documento:

“En Pintura ........... 135.280...."
En joyas e Alajas... 509.909....11 1/3
En metálico.............. 21.477... 11 1/3
Total...................... 666.666...22 1/3"

Como era usual neste tipo de partilhas, as jóias assumiam um valor muito superior ao resto dos objectos contemplados, pois que, enquanto a avaliação das pinturas dependeria de

\footnotetext{
${ }^{263}$ CHECA, Carmen García-Frías, "Nuevas aportaciones al estúdio de la colección pictórica de Carlos IV en el exilio", in Carlos IV y el arte de su reinado, Jornadas de Arte e Iconografia, Fundación Universitaria Española, Outubro, 2011, p. 217.

${ }^{264}$ CHECA, obra citada, 2011, p. 230.

265 BASTOS, Celina, "Percurso de Uma Pintura", Luca Giordano. Êxtase de São Francisco, MNAA, Março 2014, p. 9.

${ }^{266}$ CHECA, obra citada, 2011, p. 230.

267 BA. 54-X-33 (13).
} 
oscilações do gosto, ou da disponibilidade do mercado, aquelas pareciam traduzir valores mais perenes.

Sabemos hoje, conforme demonstram os contributos trazidos por Cuesta ${ }^{268}$ e Carmen GarcíaFrias-Checa que, no ano de 1827, D. Carlota se envolveu directamente na obtenção das pinturas que the eram devidas, pois tardavam a chegar a Lisboa. Como escreve esta investigadora, a obra "Traslado de Cristo al sepulcro com San Francisco de Luca Giordano [...] tuvo curiosamente de ser reclamada en 1827 por la reina de Portugal a su hermano Fernando VII, ya que permanecia todavia en Madrid"269. Por ter sido considerada pelos críticos avaliadores, obra de muito boa qualidade, acabara exposta no Museu Real de Pintura e Escultura, em Madrid, a partir de 1825, a pretexto da necessidade de um profundo restauro. Só após a reclamação de D. Carlota Joaquina ${ }^{270}$, através de D. Alfonso Yevenes ${ }^{271}$, datada de 6 de Janeiro de $1827^{272}$, as obras de arte chegariam a Portugal, vindo então enriquecer as colecções de pintura de que a soberana já dispunha. Mas tal não deverá ter ocorrido antes de 1828.

No manuscrito denominado "Tercera Division"273, destacam-se, a abrir a lista, as "Dos Marinas pintadas por Bernet", isto é, as duas marinhas de Claude-Joseph Vernet (1714-1789), avaliadas em 13.400 r.s, a justificar o crédito alcançado pelo pintor francês junto da corte de Espanha. Estas duas obras que integravam a quota de D. Carlota Joaquina poderiam ter sido das poucas pinturas que Carlos IV levara de Espanha, para Roma. Sabemos que, depois das primeiras ofertas do rei de França Luís XVI, ao então Príncipe Carlos de Bourbon, em 1781, de um par de pinturas de Vernet, representando uma "Marinha ao nascer do sol" e, outra, "Pôr do sol com banhistas", seria o então Príncipe das Astúrias a demonstrar interesse na obtenção de mais pinturas daquele artista, pelo qual nutria especial predilecção, utilizando para tal os préstimos do seu embaixador na corte francesa. Assim, às duas obras oferecidas pelo rei de França

\footnotetext{
${ }^{268}$ CUESTA, Miguel Hermoso, "A propósito de un lienzo de Lucas Jordán en el Museu Nacional de Arte Antiga de Lisboa", Anales de Historia del Arte, 2010, pp. 183-207.

${ }^{269}$ CHECA, Carmen García-Frías, "Nuevas aportaciones al estúdio de la colección pictórica de Carlos IV en el exilio", in Carlos IV y el arte de su reinado, Actas de las Jornadas de Arte e Iconografia, Fundación Universitaria Española, Outubro 2011, p. 245.

270 BASTOS, Celina, obra citada, 2013, refere as trocas de correspondência da diplomacia portuguesa com o objectivo de reaver aquela obra que pertencia por direito à Rainha de Portugal.

${ }^{271}$ Por esta ocasião o Marquês de Montemar que representava a soberana portuguesa já tinha morrido (+1826), pelo que seria já outro o seu representante, junto da herança paterna.

${ }^{272}$ CHECA, Carmen García-Frías, obra citada, 2011, p. 245.

${ }^{273}$ BA. 54-X-33 (7).
} 
somaram-se, em 1782, as seis pinturas encomendadas pelo próprio Príncipe, destinadas à decoração da sua "Casita" no Escorial274.

No manuscrito da Biblioteca da Ajuda, às duas Marinhas de Vernet, sucedia a pintura "Il Beato Rivera predicando a los infieles", de Cades $^{275}$, uma obra de carácter histórico, pois que representava um episódio da cristianização da Península Ibérica, isto é, "a evangelização dos muçulmanos no reino de Valência", missão para a qual "o arcebispo Juan de Ribera fora encarregado por Filipe III de Espanha"276, obra então avaliada em 14.000r.s., eventualmente por ser uma obra de grande formato e por tratar um assunto de especial relevo para a cultura espanhola. Em terceiro lugar, surgia a obra de Luca Giordano, ali denominada "Un descendimiento", então considerada "obra maestra de este autor", avaliada em 9.500r.s. Estas eram as obras mais valorizadas, demonstrando o mérito artístico indiscutível de cada autor e o crédito que tinham alcançado na corte espanhola. Eram, no caso de Vernet, obras que antecipavam o gosto oitocentista pela representação de paisagens, que aliavam a descrição topográfica a uma atmosfera idealizada, num gosto precursor do romantismo ${ }^{277}$; a afirmação de temáticas históricas, que substituíam a figuração de heróis da mitologia clássica, que fora cara à cultura iluminista, por episódios emblemáticos da afirmação das identidades nacionais, no caso de Cades; e a grande pintura religiosa, plena de realismo e teatralidade, no "Descendimiento" de Giordano ${ }^{278}$, obra paradigmática da tradição pictórica do barroco italiano. O que confirma o ecletismo e abrangência de gosto da colecção dos monarcas espanhóis que resultava tanto de predilecções pessoais, como da disponibilidade do mercado, nomeadamente no que respeita às aquisições efectuadas em Roma.

Nos lugares seguintes, naquela lista, e numa óbvia sobrevalorização dos seus próprios talentos, surgiam as cópias, a partir de originais de mestres italianos, realizadas pelos autores da avaliação, os pintores José de Madrazo e Juan Antonio de Ribera, que integravam o lote das dezassete obras com o valor mais elevado. Tais eram os casos de um S. Miguel, copiado por "D. Juan de Ribera del original de Guidoreni", avaliado em 8.000 r.s, ou de um "S. Sebastien, copiado por D. Jose Madrazo de un cuadro del Ticiano" avaliado em 7.600 r.s, o que

\footnotetext{
274 BOTTINEAU, Yves, L'Art de Cour dans I'Espagne des lumières, 1746-1808, Paris 1986, pp. 336-337.

275 Giuseppe Cades (1750-1799), foi um dos mais talentosos artistas da sua geração. Treinado como pintor de História a sua forma de evocar o passado foi pioneira abrindo o caminho aos pintores oitocentistas.

${ }^{276}$ SANTOS, Paula Mesquita, obra citada, 1995, p. 307.

277 BOTTINEAU, Yves, L'Art de Cour dans L'Espagne des lumières, 1746-1808, Paris 1986, p. 336.

278 CUESTA, Miguel Hermoso, "A propósito de un lienzo de Lucas Jordán en el Museu Nacional de Arte Antiga de Lisboa", Anales de historia del Arte, 2010, 20, 183-207.
} 
comparado com o valor da obra "Un descimento por Lucas Jordan", de 9.500r.s nos parecem agora excessivos.

Curiosamente, no catálogo da Bemposta, estas cópias da autoria dos pintores avaliadores espanhóis, readquiriam um lugar mais compatível com a real qualidade das obras por eles realizadas, merecendo, inclusivamente, comentários não muito elogiosos por parte dos académicos portugueses. Vejamos, a título de exemplo, a referência ao n. 119 da "Tercera Division", isto é, um "S. Miguel, copiado por D. Juan de Ribera del original de Guidoreni", quarta em valor naquela lista, mereceu no catálogo da Bemposta, onde tinha o n. 191, a seguinte entrada - "Um dito, dito, representando o Archanjo S. Miguel, figura colossal, moldura dourada; uma medíocre cópia de Guido Reni"; ou o n. "419" da "Tercera Division", sétima em valor, "La Santissima Trinidad, por D. Juan de Rivera", com a atribuição de 6.300 r.s, surge no catálogo da Bemposta, com o n. 129, descrito como "Um dito, dito, representando Jesus Christo nos braços do Padre Eterno, simbolizando a Trindade Santíssima, por Ribeira", avaliado aqui em $4 \$ 300$, valor relativamente baixo quando comparado com aquele atribuído em Espanha. A título de comparação, os valores-base das duas marinhas de Vernet, na lista da Bemposta, era de 576\$000, e o “Descimento da Cruz", de Luca Giordano, de 500\$000.

Estes são exemplos que nos demonstram o eclectismo da colecção que integrava obras de um grande sentido decorativo e outras plenas de simbolismo e solenidade, às quais se associariam outras, de pequeno formato, dignas de um Gabinete de um "amador" das belas artes. Importa referir que a estada em Roma dos monarcas espanhóis permitira o acesso a um mercado de arte que estava em plena efervescência, causada pelas invasões do exército napoleónico e a desarmotização das ordens religiosas, pelo que a disponibilidade de obras de carácter sacro era uma realidade.

A valorização das pinturas de autores académicos contemporâneos. A sobrevalorização, na "Tercera Division", das obras dos pintores académicos, com formação e prática em Roma, onde beneficiavam de alguma estima e reconhecimento, era então compatível com o prestígio que alguns daqueles pintores alcançavam junto das Academias. As invasões napoleónicas, com a sequente promulgação das leis de desamortização das ordens religiosas, o empobrecimento das elites de Antigo Regime, face ao novo contexto político, no qual emergiam outros grupos sociais, poderia justificar uma maior disponibilidade de "obras-mestras" de pintores de épocas passadas e, sobretudo, uma maior disponibilidade de pintura religiosa no mercado de obras de arte, com a consequente desvalorização destas, face ao daquelas cujos méritos eram 
certificados pelas Academias e que corresponderiam a um gosto mais "laicizado" e actualizado.

Checa, seguindo Haskell, refere o impacto da dominação napoleónica, nos territórios de Itália, e a dispersão das pinturas provenientes das grandes colecções aristocráticas ${ }^{279}$, o que teve como consequência uma maior disponibilidade da pintura italiana sendo, por essa razão, a mais bem representada na colecção dos reis no exílio, englobando as "principais escolas italianas dos séculos XV ao XVIII"280, ocupando a pintura nórdica (alemã, flamenga e holandesa) a segunda posição em número de obras e a espanhola pouco representada, o que, segundo a autora, se deveria à dificuldade de encontrá-la em Roma ${ }^{281}$.

Talvez por essa razão, a entrada com o número "49. Un pais, por Teodoro Malwef”, avaliada em 3.700r.s, apesar de integrar a quota hereditária de D. Carlota Joaquina, nunca chegaria a Portugal. Este artista, cujo nome era Theodor Michaijlovic Matveev ou Matweyev (1758-1826), constituía um caso excepcional de um pintor russo, de mérito reconhecido dentro do grupo de pintores contemporâneos estrangeiros activos em Roma, que incluía os italianos Camuccini, Benvenuti y Mezzera, que eram então especialmente apreciados, aquando do exílio dos monarcas espanhóis naquela cidade, atingindo as suas pinturas elevados valores ${ }^{282}$. Existia apenas uma obra de Matveev na colecção de Carlos IV, uma "Paisagem com figuras", segundo Checa, "concebido de forma amable y bucólica", que a autora localiza na colecção do Património Nacional, no Palácio do Escorial ${ }^{283}$. Talvez que a sua singularidade tivesse justificado a sua retenção em Espanha.

Ainda, de acordo com outro manuscrito da Biblioteca da Ajuda, relativo à herança paterna de D. Carlota Joaquina, ficamos a saber que a pintura assinalada com o número "310. Un Cuadro com Animales", atribuído a Rosa de Tivoli ${ }^{284}$, uma das obras que obtivera na avaliação um valor mais elevado, isto é, 7.080 r.s, desaparecera, misteriosamente, das cocheiras do Duque de

\footnotetext{
${ }^{279}$ CHECA, Carmen García-Frías “Nuevas aportaciones al estúdio de la colección pictórica de Carlos IV en el exilio", Carlos IV y el arte de su reinado, Actas de las Jornadas de Arte e Iconografia, Fundación Universitaria Española, Outubro 2011, p. 214.

280 Idem, p. 219.

281 Idem, p. 226.

282 CHECA, obra citada, 2011, p. 230.

283 El Escorial, n. inv. 10032376. V. Checa, 2011, p. 243.

284 Philipp Peter Roos (Frankfurt 1655-Tivoli 1706). Paisagista que desenvolveu a sua actividade em Roma reconhecido pela sua representação de animais e paisagens classicistas.
} 
Montemar, onde tinha sido colocada, devido às suas dimensões extraordinárias, segundo justificava o autor da nota.

"El Cuadro señalado com el Num. 310, representativo de vários animales, por Rosa de Tivoli, su tasa 7.080 reales que fué adjudicado à S.M.I en 4.720 reales; por ser de un tamaño extraordinário se custodió por disposicion del Señor Duque de Montemar en una de sus cocheras de donde fué robado dejando el marco; y aunque se ofició à su Testamentaria por si podia ser habido salieron infructuosas todas las diligencias que se hicieron por ella"285.

Deverá ser este o quadro que Presas refere nas suas Memórias Secretas quando aconselha D. Carlota Joaquina a vender as pinturas da herança paterna, de modo a satisfazer as quantias que, considerava, Ihe eram devidas, por serviços prestados àquele senhor, aquando da estada da corte portuguesa no Brasil. Em Maio de 1828, os quadros ainda estariam em Madrid, o que levara Presas a escrever, dirigindo-se à então Rainha-viúva, que "La coleccion de pinturas que en el repartimiento de dichas herencias há correspondido à V.M.I. y R. se está perdiendo en Madrid por estar almacenadas, sin que los encargados de su custodia puedan cuidarlas com aquel esmero que requiere su conservacion, razon á la verdad suficiente para que V.M.I y R. disponga su venta, á fin de que no queden, com un mas largo abandono, expuestas a experimentar la misma suerte que ha tenido la mejor de ellas, pues que ya há desaparecido de la vigilancia de sus apoderados [... $]^{\prime 286}$. A nota manuscrita da Biblioteca da Ajuda vai, assim, ao encontro das palavras de Presas, que por uma vez nos ajuda a elucidar os acontecimentos daquele momento histórico.

\section{VII.II - A "Tercera Division"287. A quota hereditária de D. Carlota Joaquina}

Vejamos, assim, quais as obras que integravam a quota hereditária de D. Carlota Joaquina, recebida em data incerta, mas sempre depois de Março de 1826, data do documento da partilha, relativamente às quais tentaremos associar uma proposta de atribuição, de localização, ou destino, sempre que plausível:

\footnotetext{
285 BA. 54-X-33 (7a).

286 PRESAS, José, Memórias Secretas de la Princesa del Brasil, actual Reina viúda de Portugal, La Señora Doña Carlota Joaquina de Bourbon, Burdeos, 1830, p. 277. V. BASTOS, Celina, "Percurso de uma Pintura", in Luca Giordano Extase de S. Fancisco, MNAA, 2014, p. 13.

287 BA, 54-X-33 (7).
} 


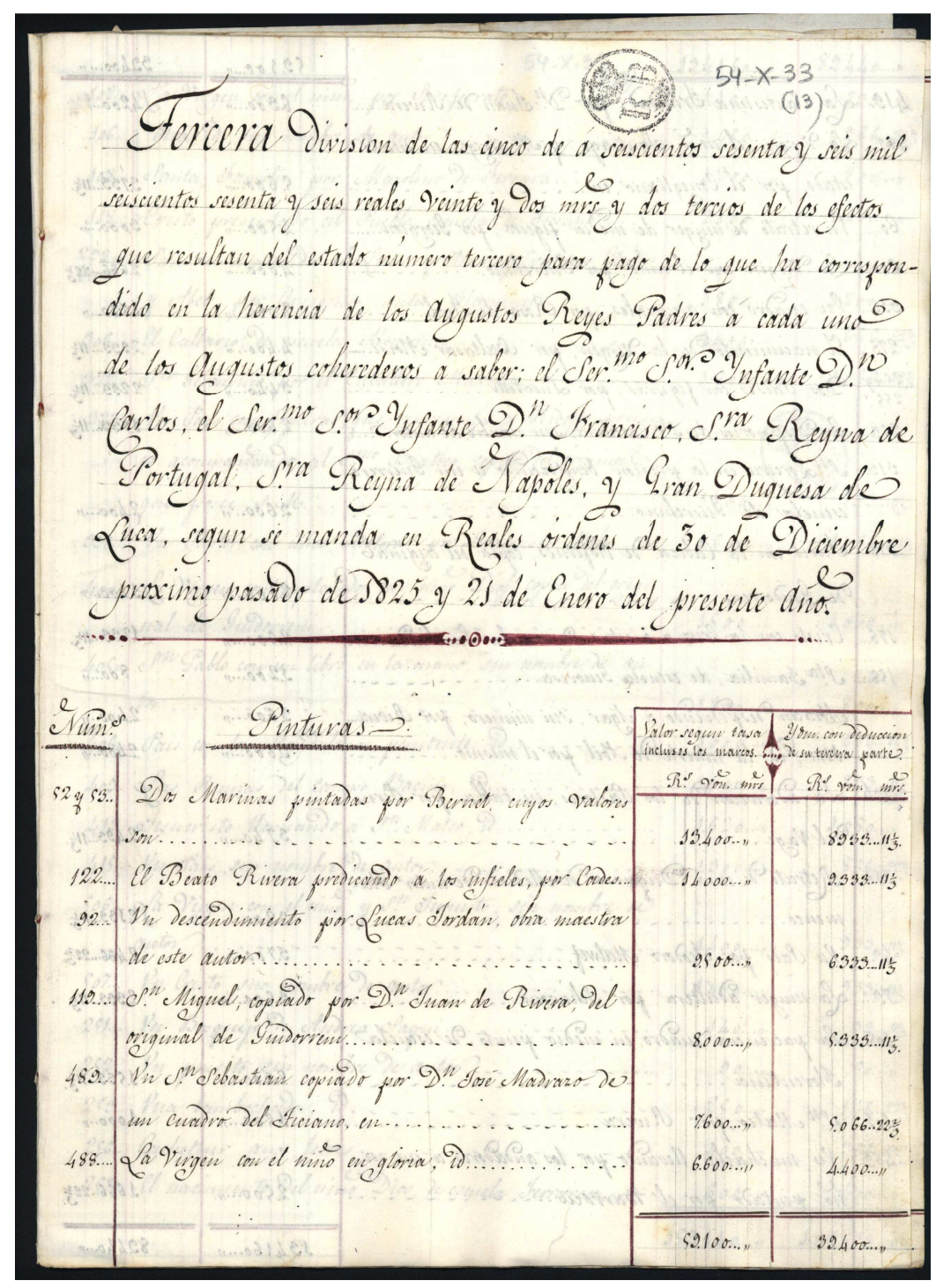

Biblioteca da Ajuda ms. 54-X-33 (13)

\section{"1826 Mar. 30, Madrid}

Tercera division de las cinco de a seiscientos sessenta y seis mil seiscentos sessenta y seis reales y dos mrs y dos tércios de los efectos que resultan del estado numero terceiro para pago de lo que há correspondido en la herencia de los Augustos Reyes Padres a cada uno de los Augustos coherederos a saber: el Ser.mo S.or Ynfante Dn. Carlos, el Ser.mo S.or Ynfante Dn. Francisco,

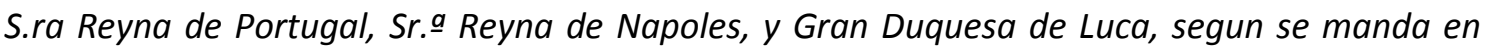
Reales ordenes de 30 de Diciembre próximo passado de 1825 y de Enero del presente ano"288. 


\section{Pinturas}

Num.s Pinturas

Valor segun tasa incluso los marcos

R.s $[\ldots]$ e mrs.

52 y 53 . Dos Marinas pintadas por Bernet ${ }^{289}$, cuyos valores son

13.400

122. Il Beato Rivera predicando à los infieles, por Cades 290

14.000

92. Un Descendimiento por Lucas Jordan, obra maestra de esse autor ${ }^{291}$

9.500

119. S. Miguel, copiado por D. Juan de Ribera del original de Guidoreni ${ }^{292}$

8.000

489. Un S. Sebastien, copiado por D. Jose Madrazo de um cuadro del Ticiano 293

7.600

488. La Virgen com el Niño en Gloria, id. ${ }^{294}$

6.600

289 Pinturas de Claude-Joseph Vernet (1714-1789). Integravam o núcleo mais reduzido de obras de Escola Francesa, presumivelmente trazidas de Espanha para Roma, já que Carlos IV dispunha de um conjunto significativo de pinturas deste autor. No catálogo do leilão da Bemposta tinham ambas o n.으 18, e tal como na lista de Espanha, fora-lhes atribuído um dos valores mais elevados das obras presentes, isto é, 576\$000, então descritas como “Dous ditos em pano, representando, um o Naufragio d'um Navio, e o outro, vista de um Porto de Mar, com uma rocha transfurada, figuras commerciaes e pescadores, representando a elevação do Sól anteposto a um nevoeiro, original de Horacio Vernet [sic]". Foram adquiridas pelo Estado português, para a Academia de Belas Artes de Lisboa e correspondem às

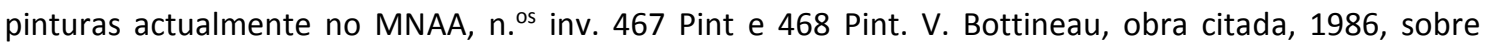
Claude-Joseph Vernet e as relações entre a corte de Espanha e a de França.

290 No catálogo da Bemposta esta pintura tinha o n. 69, sendo descrito como - "Um dito, dito, representando a Pregação do Arcebispo João Ribeiro Valencia pregando aos Gentios, por Cades, largura oito palmos e dous terços, altura treze e três quartos, moldura dourada", avaliado em $120 \$ 000$, um valor elevado, mas muito inferior, por comparação, ao que lhe fora atribuído pelos pintores avaliadores em Espanha. V. SANTOS, Paula Mesquita, “A Colecção de Pintura de D. Carlota Joaquina de Bourbon, oriunda do Ramalhão, em Sintra [...]", in Vária Escrita, Sintra 1995, p. 307. Esta obra fez parte do lote de pinturas adquiridas pelo Estado português para a Academia de Belas Artes de Lisboa e encontra-se, actualmente, no MNAA, com o n.o inv. 456 Pint.

${ }^{291}$ Esta obra do pintor régio da corte de Espanha de Carlos II (1661-1700), Luca Giordano (1632-1705), integrou o lote, adquirido pelo Estado português no leilão da Bemposta, para a Academia de Belas Artes de Lisboa. Tinha o n.o 77 do catálogo. Encontra-se no MNAA, com o n.o inv. 719 Pint. V. CUESTA, Miguel Hermoso, "A propósito de un lienzo de Lucas Jordán en el Museu Nacional de Arte Antiga de Lisboa", in Anales de Historia del Arte, 2010, 20, 183-207; Checca, 2011, obra citada; e BASTOS, Celina, 2014, obra citada.

292 Checa refere esta pintura, obra citada, 2011, p. 228, como um - "Sn. Miguel, copiado por Dn. Juan Rivera, pintor de cámara de S.M. del quadro original de Guido Reni, existente en la Yglesia de los Capuchinhos de Roma, alto 9 pies 1 pulgada, ancho 6 pies, 3 pulgadas". No catálogo da Bemposta surge com o n. 191 - "Um dito, dito, representando o Archanjo S. Miguel, figura colossal, moldura dourada; uma medíocre cópia de Guido Reni", que julgamos corresponder àquele. Foi adquirido na sessão do dia 19 de Junho de 1848, pelo Sr. Duarte José dos Passos. ANTT, Casa Real, Cx. 7311, maço 91. Este era um exemplo dos valores excessivamente altos atribuídos pelos avaliadores espanhóis às obras de sua própria autoria.

293 No catálogo da Bemposta, com o n. 68, é referido um - "S. Sebastião Martyr, cópia feita por Maximo Vicente". Madrazo tinha uma especial admiração pela obra de Ticiano que copiou durante a sua estada em Roma. Foi adquirido, na sessão do dia 15 de Junho de 1848, pelo Sr. Duarte José dos Passos. ANTT, Casa Real, Cx. 7311, maço 91. O valor atribuído na lista de Espanha era desproporcional, pois que a tornava uma das mais valiosas do conjunto, o que era uma óbvia presunção do seu autor-avaliador.

${ }^{294}$ Checa, a partir do inventário que localizou nos Arquivos espanhóis, mais completo que o da BA pois refere as dimensões, transcreve a descrição desta obra como - "La Virgen com el Niño en gloria, y algunos Angeles, copiado por Dn. José de Madrazo, de la parte superior de un quadro de Tiziano que posee el Papa". Checa, obra citada, 2011, p. 228. Esta pintura aparece no catálogo da Bemposta com o 
n.o 86, como - "Um dito em pano, representando Nossa Senhora com o Menino Jesus e dous anjos, uma cópia da parte superior de um quadro de Tiziano, que existe na Galeria Vaticana", não sendo aqui mencionada autoria. Foi adquirida na sessão do dia 26 de Maio de 1848, pelo Sr. António Ozorio de Campos e Silva. ANTT, Casa Real, Cx. 7311, maço 91.

295 No catálogo da Bemposta aparece, com o n.o 129, descrito como - “Um dito, dito, representando Jesus Christo nos braços do Padre Eterno, simbolizando a Trindade Santíssima, por Ribeira, largura seis palmos, altura nove e dous terços", então avaliado em $4 \$ 300$, valor relativamente baixo, face aos $576 \$ 000$ atribuídos às duas paisagens de Vernet, mas que na lista de Espanha surge no patamar das pinturas mais valiosas. Não por acaso o seu autor fora um dos avaliadores. Adquirido pelo Sr. João Rodrigues Blanco, na sessão de 25 de Maio de 1848. ANTT, Casa Real, Cx. 7311, maço 91.

${ }^{296}$ Cima Conegliano, pintor da Renascença italiana (Coegliano 1459-Conegliano 1517). Não identificamos esta obra no catálogo do leilão da Bemposta. Nem a conseguimos localizar. Teria ficado em Espanha?

297 Seria uma referência a GIORGIONE, Giorgio Barbarelli da Castelfranco (1477-1510) mestre veneziano? Não localizada no catálogo do leilão da Bemposta nenhuma referência compatível com esta entrada.

${ }^{298}$ Foram leiloadas várias obras com o tema da Virgem com o Menino, atribuídas a pintores italianos, os n. ${ }^{\text {os }} 62,66,116,172,173$.

${ }^{299}$ Esta obra, de acordo com o ms. BA. 54-X-33 (7a) teria sido roubada das cocheiras do Duque de Montemar. V. p. 70.

300 Baltasar Aloisi (1578-1638) pintor bolonhês discípulo de Carracci. Julgamos ser o n.o 113 do catálogo da Bemposta - "Um dito, representando Natividade de Nossa Senhora, cópia de um quadro de Escola Romana", adquirido na sessão de 19 de Junho pelo Sr. António Borges da Câmara. ANTT, Casa Real, Cx. 7311, maço 91.

${ }^{301}$ Andrea Locatelli (Roma 1695-Roma 1741), pintor do barroco italiano. O n.o 7 do catálogo do leilão da Bemposta, tem a seguinte descrição - "Dous quadros pintados em pano, representando um paiz e figuras, por um Escolar de Pussin". Poussin (1594-Roma 1665) era um mestre francês, representante do classicismo barroco, romano por escolha. Existem, no entanto, outras obras com o mesmo tema.

302 O n. 112 do catálogo da Bemposta refere - "Um dito, dito, representando Desposorio de Santa Catharina, Escola Romana", adquirido na sessão de 8 de Junho de 1848, pelo Sr. João Ortega, e outro com n.o 168, representando - "Esponsalício de Santa Catharina e S. Jeronimo, original de Parmigianino", então avaliado em 100\$000, adquirida pelo Sr. António Borges da Câmara. ANTT, Casa Real, Cx. 7311, maço 91. Não dispondo da informação sobre as dimensões da obra, não podemos avançar mais na proposta de atribuição.

303 No catálogo da Bemposta surge com o n.o 71, com a seguinte descrição - "Um dito pintado em pano, representando o Baptismo de S. Hermenegildo, original de Guerchino da Cento, largura oito palmos, altura dez e dous terços, moldura dourada", com uma base de licitação de $480 \$ 00$, e mantendo a autoria da lista de Espanha. Foi adquirido pelo Estado português no leilão da Bemposta, encontrandose actualmente no MNAA, inv. no 438 Pint., com a designação Baptismo de Santo Hermenigildo, atribuído a Esc. Italiana do século XVII. O valor atribuído pelos académicos avaliadores portugueses colocava-o entre as obras mais valiosas do conjunto, muito próximo da obra de Luca Giordano e não muito longe das duas pinturas de Claude-Joseph Vernet (1714-1789). Quanto ao estado de conservação 
198. Santa Familia, de Escuela Genovesa ${ }^{306}$

mereceu a seguinte apreciação - "N.71 - Um quadro representando o Baptismo de Santo Ermenegildo notavelmente estragado e oferece alguns maus restauros, estando tam arido que em partes a tinta se solta do panno". ANBA 1-A-SEC. 011 Acta 483, de 30 de Abril de 1859.

304 O n. 64 do catálogo da Bemposta é descrito como - "Um dito pintado em pano representando a Formosa Judith depois de ter cortado a cabeça a Holofernes, figura colossal pintado por Guido Reni, mas muito retocado, largura seis palmos e meio, altura nove e três quartos, moldura dourada", com um valor base de $250 \$ 000$. Foi adquirido pelo Estado português, no leilão para a Academia de Belas Artes, tendo recebido a seguinte apreciação dos académicos - "N. 64 - Quadro representando Judith - por Guido Reni. Gasto em geral pelas más limpezas que lhe fizeram, pessimamente restaurado, principalmente na cabeça peito, braços e extremidades inferiores, e também em todo o fundo", ANBA 1-A-SEC. 011 Acta 483, de 30 de Abril de 1859. Encontra-se actualmente nas coleções do MNAA, com n.으 inv. 452 Pint., como cópia de Guido Reni.

305 Esta obra corresponde ao n. 164 do catálogo da Bemposta, descrito como - "Um dito em meia figura, representando Jesus Christo com a Cruz às Costas; original de Luino, largura dous palmos e um quarto, altura dous e três quartos, moldura dourada", com uma base de licitação de $200 \$ 000$. Adquirida pelo Estado Português, para a Academia de Belas Artes de Lisboa, integra a colecção do MNAA, com o n. inv. 458, agora atribuída à Escola italiana do século XVI.

${ }^{306}$ No catálogo da Bemposta encontramos três obras com este tema: o n. 140 descrito como - "Um dito, dito, em cartão, representando a Sacra Família, por Parmiggianino [...] moldura dourada, muito retocado", adquirido pelo Sr. António José da Motta, na sessão do dia 15 de Junho de 1848; o n.o 177 atribuído a Franciabiggio, adquirido no dia 19 de Junho pelo Sr. José Maria da Costa da Silveira Motta (procurador da infanta D. Isabel Maria); e o n. 179, como cópia de Rafael, adquirido na sessão do dia 19 de Junho, pelo Sr. João de Deus Antunes Pinto ("procurador de S. Magde Fidelíssima", ANTT, Casa Real, Cx. 6523).

307 Julgamos tratarem-se das pinturas que no catálogo da Bemposta tinham o N.o 190, descritos como "Dous ditos, com o mesmo numero, um representando a Morte de Abel, a tempera, outro Abrahão expelindo de casa Agar [...] Escola de um pintor Romano Moderno", aos quais se atribuía um valor de $48 \$ 000$. Não andavam muito longe da verdade os académicos portugueses, ao imputarem as pinturas a pintor contemporâneo romano, pois eram as mesmas da autoria do pintor de câmara de Carlos IV no exílio, Juan Antonio de Ribera (1779-1860). Integraram o lote que foi adquirido pelo Estado português para a Academia de Belas Artes de Lisboa, pelo valor de $9 \$ 600$. Da peritagem da mesma resultou a seguinte observação: "Dois quadros em panno com o mesmo numero, representando um $A$ morte d'Abel - a tempera, e outro - Abrahão expelindo de casa a Agar. - O primeiro tem um rasgão e segundo algumas faltas de tinta", ANBA 1-A-SEC. 011 Acta 483, de 30 de Abril de 1859. Nas colecções do MNAA existe pintura com título do primeiro, n. inv. 474 Pint., assim como no Palácio da Ajuda, com o n. ํ inv. 2844 PNA) e que integrou "o acervo da Galeria de Pintura de D. Luís, figurando na Segunda Sala - Quadros Antigos com o n.o 21, da 2. edição do catálogo de 1872", (óleo s. tela 101 x 73). Seriam ambas as pinturas da autoria de um dos pintores de câmara dos Reis pais em Roma, desde 1809, Juan Antonio de Ribera, pois assim vêm atribuídos na lista proveniente de Espanha. Não foi possível localizar referência correspondente à segunda pintura.

308 Deve corresponder ao no 117 do catálogo da Bemposta - "Um dito, dito, em taboa em circulo, representando a adoração dos Pastores, primeira maneira de Rafael [...] moldura dourada", com um valor de $120 \$ 000$, adquirido pelo Estado português para a Academia de Belas Artes de Lisboa, mereceu o seguinte observação dos membros da Academia - "N.o 117 - Um quadro pintado em taboa, 
representando a - Adoração dos Pastores - Escola de Raphael - Este quadro aliás bem conservado, mostra haver sido queimado na parte posterior, e é por isso que na parte anterior se vê a cabeça e mão de $\mathrm{S}$. José pintadas todas de novo, tendo algumas fendas no fundo, e no horizonte um espaço muito mal restaurado", ANBA 1-A-SEC. 011 Acta n. 483, de 30 de Abril de 1859. Actualmente encontra-se no MNAA, n.o inv. 459 Pint.

${ }^{309}$ Esta pintura surge no catálogo da Bemposta com o n. 35, descrito como - "Um dito representando uma Imperatriz Alemã, por Bronzino, largura quatro palmos e um terço, altura seis e um oitavo, moldura dourada", tendo ido à praça por $120 \$ 000$, foi adquirida pelo Estado português para a Academia de Belas Artes de Lisboa, mereceu o seguinte observação - "N.o 35 - Uma Imperatriz Alemã por Bronzino - A cabeça e mãos alguns maus restauros, mas quasi que conservam a sua originalidade, tendo o fundo em geral muito arruinado e falta de tinta original em muitas partes", ANBA 1-A-SEC. 011 Acta 483, de 30 de Abril de 1859. Encontra-se no MNAA, n. inv. 453 Pint., atribuído actualmente a Jacoppo Ligozi (Verona 1547-Florença 1626).

${ }^{310}$ Carmen G. F. Checa identifica esta pintura no Escorial (com o n.ㅇ Inv. 10032376), na sequência de trocas que terão existido entre os diversos conjuntos da herança atribuídos a cada herdeiro, pelo que não veio para Lisboa. V. Checca, obra citada 2011, pp. 230, 242 e 243.

311 Esta pintura foi vendida, no dia 25 Abril de 2008, pela leiloeira Christie's, em Londres, como proveniente da antiga coleção da rainha D. Carlota Joaquina de Bourbon, sendo atribuída a Andrea Meldolla, lo Schiavone (Zadar, Croácia, 1500-1563 Veneza) e oficina. Desconhecemos o actual paradeiro. O catálogo da Bemposta, com o n. 81, refere - "Um dito, dito, representando a Mulher Adultera apresentada a Jesus Christo, original da maneira larga de Tiziano, meia figura". Foi à praça com um valor de 250\$000, tendo sido adquirida pelo Sr. Bartolomeo Dias de Sousa, na sessão que decorreu no dia 15 de Junho de 1848, por 60\$000. ANTT, Arquivo Casa Real, Cx. 7311, maço 91.

312 Esta pintura tinha o n.o 63 no catálogo da Bemposta, descrita como - "Um dito pintado em taboa, representando a Paciencia, [...] por Pierino del Vago, discípulo de Rafael [...] então avaliada em 400\$000, integrou o lote de aquisições efectuado pelo Governo para a Academia de Belas Artes de Lisboa - "N.으 63 - Um quadro pintado em taboa representando a Paciência - por Pierino del Vago - Pela maior parte bem conservado, tendo nas roupas alguns péssimos restauros faltando-lhe no fundo alguma tinta original", ANBA 1-A-SEC. 011 Acta 483, de 30 de Abril de 1859. Encontra-se, actualmente, no MNAA, com o n. inv. 461 Pint, atribuído a autor desconhecido, em dúvida, a Rafael Sanzio.

${ }^{313}$ V. Checa, 2011, p. 227, diz tratar-se de pintura sobre madeira, acrescentando "que no se conoce ninguna representacion de este santo com este soporte y medidas". No Palácio da Ajuda existe um "S. Mateus", PNA Inv. n.o 483, óleo sobre tela, atribuído a Pierre Hubert Subleyras (1699-1749). No catálogo da Bemposta não aparece nenhuma pintura com a representação de S. Mateus, pelo que poderá não ter ido a leilão.

314 Não localizada nenhuma obra ou referência compatível com o tema descrito.

315 Com o n.o 127, no catálogo da Bemposta surge - “Um dito, representando Nossa Senhora com o Menino Jesus dormindo, cópia de Sasso Ferrato". De Espanha vieram duas obras com a mesma designação, uma com nome de autor, outra sem. Podemos presumir ter sido vendida a cópia, e a outra pintura corresponder à que se perdeu no incêndio da galeria do Palácio da Ajuda, em 1974, atribuída a Sasso Ferrato, referida por Hugo Xavier, obra citada, 2013, p. 298. 
292 y 293. Sanson matando al Leon, y Adam y Eva, con Caín y Abel, por Crispino autor flamenco ${ }^{318}$

323. Un Pais con figuras que representa a Ridolfo primero acompanhando al S.mo Biatico, copia del original que pose S.M.

${ }^{316}$ Esta pintura foi leiloada na Bemposta, com o n.o 175, e integrou o lote adquirido pelo Estado português. Foi então avaliada como "da sublime e primeira maneira de Rafael [...], por quinhentos mil e cem reis", ANBA 1-A-SEC. 011 Acta 483, de 30 de Abril de 1859. Integra actualmente o acervo do MNAA, n.o inv. 460 Pint, com a designação - "A Sagrada Familia, Santa Ana e São Francisco", óleo sobre madeira, atribuído a Ludovico Mazzolino (Ferrara 1480-Ferrara 1528).

317 Deverá corresponder à pintura com o n.o 178, do catálogo da Bemposta - "representando Jesus Christo com a Canna verde, no Pretorio de Pilatos, apresentado ao Povo [...] original de Sebastião del Piombo", adquirida pelo Estado português, para a Academia de Belas Artes de Lisboa. Da peritagem da mesma, pelos membros da Academia de Belas Artes, resultou a seguinte observação: "Um dito representando Jesus Christo com a vara verde no Pretorio de Pilatos apresentado ao Povo pelo mesmo, bastante arruinado, original de Sebastião del Piombo". ANBA 1-A-SEC. 011 Acta 483, de 30 de Abril de 1859. Integra actualmente as coleç̧ões do MNAA, com o n.o inv. 454 Pint, como cópia de Ticiano, o que vai de encontro à atribuição da Relação de Espanha.

${ }^{318}$ Estas duas pinturas integravam a categoria de "Mediano", atribuídas a "Crispino autor flamenco" que Carmen Checa diz tratar-se de Crispin van der Broeck, grande colaborador de Frans Floris. Checa, obra citada, 2011, p. 224, nota rodapé. No catálogo da Bemposta localizamos, com o n.o 85, a pintura "Abel e Caim lutando com as feras", vendido ao Sr. Raimundo José Pinto, na sessão do dia 19 de Junho de 1848, e com o n.o 79 - "Um dito, dito, representando Adão, Eva, Caim e Abel”, ambos atribuídos a Palma, "bastante repintado". Jacopo Palma (1480-Veneza 1528). Deste último não foi localizado recibo de venda.

${ }^{319}$ No Palácio da Ajuda encontra-se um "Calvário", inv. N.o 492 P, atribuído à Escola Alemã, que tem exactamente a mesma denominação da relação de Espanha. No catálogo da Bemposta surgem 2 Calvários, um atribuído a "um discípulo de Rubens", em cobre, com o n.o 131; outro, da "Escola de Rubens", em tábua, com o n.o 180, que foi adquirido pelo sr. António Borges da Câmara. ANTT, Casa Real, Cx. 7311, maço 91. O facto de não dispormos nem das dimensões, nem de mais informação técnica, impede-nos de ir mais além na proposta de localização desta pintura.

320 Julgamos tratar-se do pintor Maximo Stanzioni, El cabellero Maximo, (Nápoles 1585-1656), discípulo de Guido Reni e Caracciolo, in Catálogo provisional historial razonado del Museo Nacional de Pinturas, Madrid, 1865. No catálogo da Bemposta, encontramos 3 pinturas dedicadas a S. Jerónimo - uma com o n.o 111, atribuída "Mr. Valentin" (seria o pintor francês Valentin de Boulogne, 1591-Roma 1632?); outra com o n.o 170, atribuída a Hespanholete (diminutivo de José de Ribera 1591-1652); e outra, com n.o 171, a Lanfranco (Giovanni Lanfranco Parma 1582-Roma 1647). No Palácio da Ajuda existe um "S. Jerónimo", inv. n.o 3679, atribuído a Giorgio Francesco Barbieri, Guercino (Cento 1591-1666). Seria este último? V. XAVIER, Hugo, 2013, p. 269. Tal como já escrevemos, não dispondo da lista com as dimensões das obras, que se encontra nos arquivos de Espanha, não podemos propor nenhuma atribuição para esta referência.

${ }^{321}$ Pier Francesco Mola (Suíça 1612-Roma 1666), pintor do barroco italiano. Não localizamos. Poderá ser o n.o 12 do catálogo da Bemposta, descrito como - "Um dito pintado em pano, representando A Cahida d'um raio, dous Pastores fugindo com os gados, original de Nicoláo Pussin [...]; ou, o n.o 51, descrito como -"Um dito pintado em pano, representando Pastores e Gados, Escola de Salvador Roza, largura quatro palmos e sete oitavos, altura quatro ditos, moldura dourada". Fica a dúvida 


\footnotetext{
${ }^{322}$ Ver catálogo da Bemposta o n.o 66, como - "Um dito, dito oval, representando Nossa Senhora com o Menino dormindo, cópia antiga de Guido-Reni, muito retocado, largura cinco palmos e três quartos, altura quatro palmos, moldura dourada" que foi à praça por $40 \$ 000$, adquirido pelo Sr. João Rodrigues Blanco (ou Blanc) ANTT, Casa Real, Cx. 7311, maço 91.

${ }^{323}$ Não localizamos no catálogo do leilão da Bemposta nenhuma referência a pintura com esta temática. No Palácio da Ajuda, "Cabeça de S. Paulo", n.o inv. 41571, não corresponde à descrição.

${ }^{324}$ No catálogo da Bemposta encontramos duas obras dedicadas à representação da Maria Madalena: n.o 80 - "Magdalena no Deserto, meia figura, que parece ter sido um bello Autor, hoje muito mal retocado", valor $4 \$ 800$, vendido por $6 \$ 900$, ao sr. António Borges da Câmara, a 23 de Maio de 1848; e, com o no 184 - "Magdalena no deserto, e paisagem, Escola Napolitana", vendida a 25 de Maio de 1848, ao sr. José António Affonso Dias. ANTT, Casa Real, Cx. 7311, maço 91. A pintura do PNA, n.o inv. 495, atribuída a Mola, Pier Francesco, (1612-1666), a paisagem não se destaca como elemento definidor da composição.

325 Pode ser a obra que surge no catálogo da Bemposta com o n.o 50 - "Um quadro em pano, representando o antigo Campo de Vaccino em Roma, com grupos de Figuras e Gados, por Bambocci, largura seis palmos, altura quatro e um quarto, moldura dourada", tendo ido à praça por $38 \$ 400$, foi adquirido pelo sr. Jacinto da Silva Falcão, no dia 5 de Junho de 1848. ANTT, Casa Real, Cx. 7311, maço 91.

${ }^{326}$ Não localizada nenhuma obra com este título. No entanto, no catálogo da Bemposta surge com n.․․ 76 - "Um quadro pintado em pano representando Jesus Christo que diz a profano q deixe o comercio e o acompanhe [...], o que se assemelha ao episódio em que Jesus diz a Mateus que o siga, segundo as Escrituras Sagradas. Foi adquirido pelo Sr. António Borges da Câmara, no dia 19 de Junho de 1848. ANTT, Casa Real, Cx. 7311, maço 91. Poderia ser esta obra a referenciada no manuscrito das partilhas.

327 Não localizamos no catálogo da Bemposta nenhuma entrada relacionável com esta representação, pelo que a mesma pode não ter sido vendida. Integra as colecções do Palácio da Ajuda um óleo sobre tela - "Virgem com o menino e S. João", inv. n.o 1344 P., atribuído a Annibale Carracci e que pertenceu à Galeria de Pintura do Rei D. Luís, zona dos Quadros Antigos. V. XAVIER, Hugo, obra citada, 2013, p. 286.

328 Poderia ser o n.o 15 do catálogo da Bemposta - "Um dito em pano representando um Bosque, de Autor incógnito", adquirido pelo sr. Hermano Frederico Moser, no dia 15 de Junho de 1848. ANTT, Casa Real, Cx. 7311, maço 91.

${ }^{329}$ Com o n.o 82 foi a leilão - "Um dito em taboa, representando uma Bamboxata, cópia de David Teniers, largura palmo e meio, altura um e um quarto, moldura dourada", com base de licitação de $4 \$ 800$, adquirida pelo sr. Raimundo José Pinto, no dia 23 de Maio de 1848, por 10\$500. ANTT, Casa Real, Cx. 7311, maço 91. No entanto, em diversos inventários do Ramalhão surgem referências idênticas, com atribuição àquele autor, enquanto a pintura vinda de Espanha não tem menção de autoria.
} 
261 y 262. Dos batallas pequenas creidas de Wirmans ${ }^{332} 700$

263. Otra, id., sin nombre de autor ${ }^{333} 240$

265. Otra, id., id. ${ }^{334} 350$

266. Otra, id., id. ${ }^{335} 350$

$\begin{array}{ll}\text { 267. Un Paisito por Ysac-van-Ostade } & 740\end{array}$

268. Otro id.,id. 740

269. Outro id. Oblado por Monpez ${ }^{337} \quad 180$

270. Otro id. del mismo autor 400

273. Outro id. con Animales, sin nombre de Autor ${ }^{338} 700$

275. Estér acusando à Amán, id. ${ }^{339} 490$

${ }^{330}$ No catálogo da Bemposta, com o n.o 124, surge obra intitulada - “Um dito, representando um Velho e uma Velha, em acto de lacrar uma carta, Eschola Flamenga [...]", avaliado em 31\$200. Não foi possível, no entanto, localizar o recibo de venda, nem a obra.

${ }^{331}$ Não localizamos no catálogo do leilão da Bemposta nenhuma obra relacionável com este título. XAVIER, Hugo, refere a pintura "A Natividade", n.o 77 do catálogo da Galeria do Rei D. Luís, de 1872, como obra pintada em madeira de Escola Florentina, no entanto, não localizada. Teria alguma relação com esta vinda de Espanha? Ter-se-ia perdido no incêndio de 1974? Não sabemos.

${ }^{332}$ No catálogo da Bemposta encontramos, com os números 59, 60 e 61, cinco pinturas alusivas a batalhas que poderiam corresponder a estas cinco obras. Com o n.o 59 - "dous ditos com o mesmo número pintados em cobre, representando duas Batalhas de Bursardon [...]"; com o n. 60, exactamente a mesma descrição, dimensões ligeiramente diferentes; com o n.o 61 - "O Despojo de uma Batalha, por um discípulo de Borgonhone", todos com as respectivas molduras douradas. Seriam estas pinturas relativas à herança, as que foram leiloadas? Existem no PNA diversas representações de batalhas, de pequeno formato, em óleo sobre tela, que poderiam, de igual modo, corresponder às vindas de Espanha. Ficam as dúvidas.

${ }^{333} \mathrm{Idem}$.

${ }^{334} \mathrm{Idem}$.

${ }^{335}$ Idem.

${ }^{336}$ Isaac von Ostade (1621-1649) paisagista flamengo. De difícil localização. Foram vendidas várias paisagens na Bemposta incluindo o " $\mathrm{n}$ - $106-3$ Quadros do restaurador que estragou os quadros do Palácio, o Hespanhol Félix Terres, de paisagem, valor só de molduras". V. catálogo do leilão da Bemposta.

337 Estas pinturas, a 269 e a 270 que sucede, ditas ovadas, podem corresponder às que tinham o n.․ 10 no catálogo da Bemposta, descritas como - "Dous quadros pintados em pano representando paisagem de João Bussiri ovados ao baixo, largura dous palmos, altura um e meio", que foram adquiridas pelo Estado português e pertencem actualmente às colecções do MNAA, n.o inv. 472 Pint., atribuídas a Joos de Momper, Esc. Flamenga séculos XVI-XVII. A atribuição a "Monpez" pode corresponder a uma corruptela do nome daquele pintor flamengo. Mereceram a seguinte apreciação por parte dos pintores académicos - "N.⒑ Dous quadros pequenos, em panno, representando Paisagem, por João Baptista Bussunni, figura oval, retocados e um tanto estragados, faltando-lhes alguns bocados de tinta original", ANBA 1-A-SEC. 011 Acta 483, de 30 de Abril de 1859. V. SANTOS, Paula Mesquita, "A Colecção de Pintura de D. Carlota Joaquina de Bourbon, oriunda do Ramalhão, em Sintra [...]", in Vária Escrita, Sintra 1995, p. 304.

${ }^{338}$ No catálogo da Bemposta não encontramos referência específica ao tema. No entanto, no Palácio da Ajuda, com o n.o inv. 2241, encontramos - "Paisagem com animais", óleo sobre madeira, de 1792, atribuída a KLENGEL, Johan-Christian (1751-1824), de pequenas dimensões.

${ }^{339}$ Não foi possível localizar, no catálogo do leilão da Bemposta, nenhuma pintura com este tema. Nas coleç̧ões do Palácio da Ajuda existe a pintura - "Ester aos pés de Assuero", de autor desconhecido, 
285. El Paraiso terrenal, estilo de Albano ${ }^{342} 660$

286. Un Paisito com figuras por G (ou I).D.W. ${ }^{343} 300$

287. Otro, id., id. 300

288. Marina en forma circular de autor Flamenco ${ }^{344} \quad 120$

289. Fracmentos de un cuadro del maná, sin nombre de autor ${ }^{345} 500$

291. Cabeza de un Pastor sin nombre de autor 520

297. Un Paisito, id. $\quad 70$

294. Un Calbario, por Laballés ${ }^{346} \quad 600$

295. Orfeo encantando a los animales com el son de su Lira ${ }^{347} \quad 160$

óleo sobre tela, séculos XVI-XVII, n.o inv. $415 \mathrm{P}$ que pertencia às colecções reais. Poderia ser esta a obra proveniente da herança paterna.

${ }^{340}$ A pintura pode corresponder ao n.o 74 do catálogo da Bemposta, ou ao n. 107, do mesmo catálogo, sendo esta última em cobre.

${ }^{341}$ Poderá ser o n. 20 do catálogo da Bemposta, descrito como - "Um quadro em pano, representando uma vista de Mar, e um pôr de sol anteposto ao Nevoeiro. Copia de horizonte, dous palmos e sete oitavos de larg. e dous de alt.", com moldura dourada.

342 Seria Francesco Albani (Bolonha 1578-1660), discípulo da Agostino Carracci? Não localizamos nenhuma obra com este título. O n.o 135 do catálogo da Bemposta - "Um dito, dito, em cobre, representando a Creação do Mundo, Adão e Eva, original de Bruegel, aveludado [...]", cujo tema se poderia aproximar do relativo a esta entrada.

${ }^{343}$ No catálogo da Bemposta com o n.o 7 encontramos a seguinte descrição - "Dous quadros pintados em pano representando um paiz e figuras, por um Escolar de Pussin e um dito, dito e do mêsmo Autor, larg. dous palmos, e um e meio d'altura" que pode corresponder a esta entrada e à seguinte, adquiridos pelo sr. Hermano Frederico Moser, na sessão do dia 5 de Junho de 1848. ANTT, Casa Real, Cx. 7311, maço 91.

${ }^{344}$ O n.o 107 do catálogo da Bemposta tem a seguinte descrição - "Um dito pintado em cobre, representando uma Marinha, autor incognito moldura com circulo redondo de meio palmo, moldura dourada", adquirida pelo Sr. Raimundo José Pinto, no dia 1 de Junho de 1848. ANTT, Casa Real, Cx. 7311, maço 91. A entrada n.o 74, daquele catálogo, é descrita como - "Um quadro em pano representando Marinha com figurinhas, Escola Flamenga [...]", não sendo, no entanto, mencionada a "forma circular". Foi adquirido pelo Sr. António Borges da Câmara, no dia 23 de Maio de 1848. Avaliado em 4\$800, foi vendido por 6\$400. ANTT, Casa Real, Cx. 7311, maço 91.

${ }^{345}$ No catálogo do leilão da Bemposta encontramos, com o n.o 189, a seguinte referência - “Dous ditos pintados em pano, representando a Adoração do Menino, original de Pintoriquio, Escola de Rafael, tão mal restaurado que pouco se observa da sua originalidade, e outro representando o Povo d'Israel recebendo o Maná, Escola Romana, o qual se acha tão mal restaurado que lhe roubou o seu valor [...]". Poderia ser esta segunda referência a relativa ao quadro vindo de Espanha. Não foi possível localizar recibo de venda, pelo que poderá não ter chegado a ser leiloado.

${ }^{346}$ No catálogo do leilão da Bemposta surgem dois calvários, um sobre cobre com o n. 131, e outro sobre tábua com o n.․ 180, ambos atribuídos a discípulos de Rubens.

${ }^{347}$ Poderá corresponder à entrada n.o 21 do catálogo da Bemposta, descrito como - "Um dito em pano, representando Orpheu encantando os animaes com sua voz, paizagem original de Brugel, da sua maneira franca, largura dous palmos e um terço, altura um e meio, moldura dourada, por $120 \$ 00 ”$. Foi adquirido pelo Sr. António Borges da Câmara, na sessão do dia 15 de Junho de 1848. ANTT, Casa Real, Cx. 7311, maço 91. 
303. S. Francisco sin nombre de autor ${ }^{348} 240$

109. Una Magdalena, escuela de Ticiano ${ }^{349} \quad 2.600$

304. Los Desposorios de S.ta Catalina, sin nombre de autor ${ }^{350} 740$

305. Sn. Francisco en un Pais, id. ${ }^{351} 400$

307. Pais com figuras que se bañan, id. ${ }^{352} 290$

309. Ruinas, sin nombre de autor ${ }^{353} 760$

326. Una Marina, id. ${ }^{354} 600$

327. Cabeza de un Apostol, id. ${ }^{355} \quad 160$

328. Cabeza de un Bufon, id. ${ }^{356} \quad 800$

348 No catálogo da Bemposta surgem duas representações de S. Francisco, uma em tábua, com o n. 169 - "Um dito representando S. Francisco recebendo as Chagas, cópia de Cigoli"; outra em tela, com o n.을 185 - "S. Francisco de Assis recebendo as Chagas, esboço de Tiziano [...]", relativamente aos quais não foi possível localizar recibos referentes à venda. No Palácio da Ajuda existem dois óleos sobre tela com representação do Santo, um inv. n.o 2782 P. e outro, inv. n.o 481 P., que esteve na Galeria de Pintura do Rei D. Luís, n.o 6 do catálogo de 1872. V. XAVIER, Hugo, obra citada, 2013, p. 247.

${ }^{349}$ No catálogo da Bemposta encontramos duas obras dedicadas à representação da Maria Madalena, sendo que esta pode ser a n.ㅇ 80 - "Magdalena no Deserto, meia figura, que parece ter sido um bello Autor, hoje muito mal retocado", valor $4 \$ 800$, vendido por $6 \$ 900$, ao sr. António Borges da Câmara, a 23 de Maio de 1848. ANTT, Casa Real, Cx. 7311, maço 91. No MNAA existe uma "Santa Maria Magdalena (Escola veneziana)", atribuída a Tiziano Vecellio, século XVI, n. inv. 1610, que esteve na Galeria de Pintura do Rei D. Luís, com n. 68 no catálogo de 1872. No entanto, XAVIER, Hugo, obra citada, 2013, p. 279, afirma ter esta última pintura feito parte de um lote adquirido, em Itália, pelo Rei D. Luís, em 1867. 350 No catálogo do leilão da Bemposta encontramos dois casamentos místicos, um n.o 112 “Despozorio de Sta Catharina, escola Romana", em pano, avaliado em $24 \$ 000$ e vendido por $42 \$ 000$, ao Sr. João Ortega, na sessão do dia 8 de Junho de 1848; outro com o n.o 168 - "Esponsorio de Sta Catharina e S. Jerónimo original Parmigianno", em tábua, avaliado em 100\$00 e vendido por 26\$000, ao Sr. António Borges da Câmara, na sessão do dia 19 de Junho de 1848. ANTT, Casa Real, Cx. 7311, maço 91.

351 V. nota 350.

352 No Palácio da Ajuda existe uma pintura "Paisagem com banhistas", inv. n. $3227 \mathrm{P}$, de pequenas dimensões, atribuída a Poelenburgh, Cornelis van, (1586-1667), que, no entanto, terá sido uma aquisição de D. Luís. Ver "Álbum de caricaturas do Rei D. Luís", Matrixpiz, DGPC consulta online e XAVIER, Hugo, obra citada, 2013, p. 284. No catálogo da Bemposta não foi localizada nenhuma entrada compatível com esta referência, pelo que não terá passado no leilão.

${ }^{353}$ No catálogo da Bemposta encontramos com os n. ${ }^{\text {os }} 52$ e 53 representações de - "Ruinas de Roma", com dimensões diferenciadas, uma atribuída a "um Escolar de Francisco Pannini" e a outra como um "Original de Pannini" que podiam já pertencer, previamente, às colecções de D. Carlota Joaquina.

354 Com o n.o 120 do catálogo da Bemposta encontramos - "Um dito, dito, representando Marinhas, cópia de Vernet, largura cinco palmos e um terço, altura dous palmos, moldura dourada", com um valor de $9 \$ 600$, relativamente baixo. Não localizei recibo de venda desta obra na documentação sobre o leilão da Bemposta.

355 No Palácio da Ajuda existe uma pintura - "Cabeça de S. Paulo", óleo sobre tela, n.o inv. 41571 P, de autor desconhecido.

${ }^{356}$ V. XAVIER, Hugo, obra citada, 2013, n.o 44 “Cabeça - Estudo (Escola holandesa)". Existirá alguma relação entre uma referência e esta entrada? 
${ }^{357}$ XAVIER, Hugo, in Galeria de Pintura no Real Paço da Ajuda, INCM, 2013, pp. 235-236, faz referência a uma pintura, mencionada num inventário do PNA, realizado em 1889, com o título de "Eremita" que teria estado na Galeria de Pintura do Rei D. Luís, "na sala dos quadros antigos", aí mencionada como da "Escola hespanhola. Atribuído a Murillo". Santo Onofre é representado como um eremita pelo que poderia ser esta pintura a correspondente ao lote hereditário. O seu paradeiro é desconhecido.

358 Tanto esta entrada, como a n.o 337, referem retrato de um homem. No catálogo da Bemposta, com os n. ${ }^{\text {os }} 2$ e 3, são descritas duas pinturas sobre tela, representando a n.o 2 - "Um Cavalleiro antigo, meia figura, Escola Loilio [...]" e o n. 3 - "Um Desembargador, meia figura ao natural, pelo Cavalleiro Vellasques", ambos com as respectivas molduras douradas. Foram adquiridos pelo Estado português, para a Academia de Belas Artes e encontram-se nas coleç̧ões do MNAA, com n. ${ }^{0 s}$ inv. 465 Pint e inv. 466 Pint, estando ambos atribuídos à "Escola espanhola, séc. XVII". Seriam estes dois retratos provenientes da herança paterna? Faltam-nos mais elementos para assumir tal. Fica a hipótese.

${ }^{359}$ Não localizada nenhuma referência compatível.

${ }^{360} \mathrm{~V}$. nota 321. No catálogo da Bemposta encontramos três pinturas dedicadas a S. Jerónimo.

${ }^{361}$ Esta pintura e a seguinte, n. ${ }^{\circ 5} 333$ e 334, podem corresponder ao n.o 19 do catálogo da Bemposta, descritas como - "Dous ditos em pano, representando uma Vista de Marinha de noute, Escola Franceza, largura três palmos, altura dous e um oitavo, por $24 \$ 000 "$, adquiridas pelo Sr. D. José Maria da Costa Silveira da Motta, no dia 15 de Junho de 1848, por aquele valor. ANTT, Casa Real, Cx. 7311, maço 91. Este comprador era procurador da Infanta D. Isabel Maria, pelo que pode ter feito a aquisição para si próprio ou para a sua representada.

362 Idem, ibidem.

${ }^{363}$ No catálogo da Bemposta surge com o n.o 65 uma pintura descrita como - "Um dito, dito, representando Herodes com a cabeça do Baptista, meia figura ao natural, pintado por Poliodoro da Caravagio, largura três palmos e meio, altura quatro e três quartos, moldura dourada". No entanto, o valor pelo qual foi à praça, isto é, $60 \$ 000$ demonstra bem a pouca credibilidade da atribuição. Foi adquirida pelo Sr. António Borges da Câmara, na sessão do dia 1 de Junho de 1848. ANTT, Casa Real, Cx. 7311, maço 91.

${ }^{364}$ Poderá ser o n.o 11 do catálogo da Bemposta, descrito como - "Dous ditos representando paisagem e figuras [...]", vendido ao Snr. João Rodrigues Blanco, na sessão de 29 de Maio de 1848. ANTT, Casa Real, Cx. 7311, maço 91.

365 Bamboccio era a alcunha de Pieter Bodding van Laer (Haarlem 1599-1641 ou 1642), pintor holandês activo em Roma, onde desenvolveu uma pintura de género, tendo seguidores. Não localizamos no catálogo do leilão da Bemposta nenhuma pintura com este tema.

${ }^{366}$ Não localizamos no catálogo do leilão da Bemposta nenhuma entrada com este tema. No Palácio da Ajuda existe uma pintura que representa um guerreiro, com o título - "O Triunfo do Vencedor", óleo sobre tela, século XVII-XVIII, n.․ inv. 41385P, que pertencia às colecções reais. Tendo estado na Galeria de Pintura do Rei D. Luís, salvou-se do incêndio. http://www.matriznet.dgpc.pt/MatrizNet consulta online Dezembro 2018. 
206 y 207. Dos cuadritos de autor Flamenco, el uno representa el martirio de S. Sebastian,

y el outro una batalla

1.200

385. El martirio de S. Pedro, sin nombre de autor 368

6.000

El martirio de un bispo ante la presencia de un tirano, sin numero ni autor ${ }^{369} \quad 3.000$

340. Marina y Ruinas, sin nombre de autor

120

341. Un cuadro en forma oval q.e representa una Virgen, id. ${ }^{370}$

540

97 y 98. La adoracion de los S.tos Reyes y la Huyda de Egipto, id. ${ }^{371}$

458. Retrato de una Señorita com un perro, por Pompeo Batoni 372

2.000

197.890

Cuadros separados por malos

39. Vista de Marsella sin nombre de autor

367 No catálogo da Bemposta, a entrada com o n.o 128 é descrita - "1 dto em taboa representando Jesus Christo no Sepulchro estando 3 Apostolos em acção d'ajuda-lo a meter ao Sepulchro avistando-se da parte de traz em massa escura uns Anjos, figura inteira, original tocado com muita franqueza, mas muito mal restaurado, Eschola Veneziana, largura sete palmos e um oitavo, altura tres e um terço, sem moldura". Considerando o valor de 9.500 atribuído à outra obra de Giordano, e o valor tão inferior desta, questionamos a certeza com que os inventariantes espanhóis consideraram esta atribuição. Aliás Checa, obra citada, 2011, p. 223, em nota de rodapé, menciona que o n.o 199, atribuído a Luca Giordano, "imitando el Parmigianino, alto 2 pies 4 pulgadas, ancho 5 pies", era "en tabla". Questiona, no entanto, a atribuição a Giordano, por a obra se dizer executada sobre madeira. Poderia ser esta pintura, leiloada na Bemposta, agora sem atribuição precisa.

${ }^{368}$ Surge no catálogo da Bemposta com o n. 70, uma pintura descrita como - "Um dito, representando - Martyrio de S. Pedro Apostolo, copia de Hanibal Caracci feita por Poliodoro de Caravagio", que presumimos seja a correspondente ao lote hereditário. Foi adquirida pelo sr. António Borges da Câmara, na sessão do dia 23 de Maio de 1848. ANTT, Casa Real, Cx. 7311. Este é mais um exemplo de atribuições, por vezes fantasiosas, dos avaliadores.

369 Julgamos ser o n.o 67 do catálogo da Bemposta, aí descrito como - “Um dito, dito, representando o Martyrio de um Bispo, figuras ao natural, da primeira maneira de Rubens, amaneirado, largura oito palmos dous terços, altura treze e três quartos [...]", com valor de licitação de $500 \$ 000$, bastante elevado. Foi adquirido pelo Estado português para a Academia de Belas Artes. Mereceu a seguinte observação dos académicos - “N.o 67 - Quadro representando - Martyrio d'um Bispo - Escola de Rubens - Muito estragado e pessimamente restaurado" ANBA 1-A-SEC. 011 Acta 483, de 30 de Abril de 1859. V. SANTOS, Paula Mesquita, A Colecção de Pintura de D. Carlota Joaquina de Bourbon, oriunda do Ramalhão, em Sintra [...], in Vária Escrita, Sintra 1995, p. 305. Integra actualmente as colecções do MNAA, com o n. inv. 457 Pint.

370 No catálogo da Bemposta surge com o n. 62 - "Um quadro em pano, representando Nossa Senhora com o Menino Jesus, copia de Julio Romano, forma oval, largura quatro palmos, altura cinco e um terço, moldura dourada" que foi à praça por $48 \$ 000$, sendo adquirido pelo Sr. João d'Hortega, na sessão de 15 de Junho de 1848. ANTT, Casa Real, Cx. 7311, maço 91.

${ }^{371}$ Catálogo da Bemposta, a entrada n.o 133 refere - "Dous ditos, dito, em taboa, em figura gótica, representando a Adoração dos Reis Magos, por Luca de Leida, e outro dito, representando a Adoração dos Anjos ao Menino Jesus, e a Fuga do Egipto, pelo mesmo autor [...] este ultimo bastantemente retocado". Tendo sido adquiridos pelo Estado português para a Academia de Belas Artes, integram as

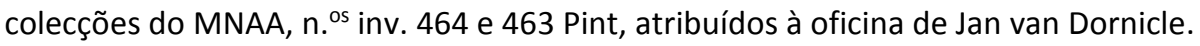

372 No catálogo da Bemposta surge com o n. 39 - "Um dito, dito, representando uma Menina brincando com um cãozinho, Escolla de Rafael Mengs, largura quatro palmos, altura dous e um oitavo", que foi à praça por $30 \$ 000$, sendo adquirido pelo Sr. Bartolomeu dos Mártires Dias de Sousa, no dia 5 de Junho de 1848, por 30\$100. ANTT, Casa Real, Cx. 7311, maço 91. 
41 y 42. Dos Vistas de Tivoli, id. ${ }^{373} 190$

43. Un Paisito Flamenco en cobre, id. 20

44 y 45. Dos Paises, id.,id. 100

46. El Señior ante Pilatos, id. $\quad 340$

47. Un S. Juan Bautista, id. 120

48. Un Pais, id. $\quad 500$

49. La Virgen com el niño, id. 500

50. Una Cabeza de S. José, id. 160

51. Una perspectiva com figuras, id. 300

52. Un Paisito com figuras, id. 240

53. Otro id, id. 340

54. Una cabeza de hombre coronada de laurel, id. 320

55. Un retrato de muger, id., id. $\quad 40$

56. Cristo con la cruz a-cuestas, id. ${ }^{374} 60$

77. Pais com Lot y sus hijas, de autor Flamenco ${ }^{375} \quad 300$

83. Una Dolorosa, sin nombre de autor 300

95. Un Pais, id. $\quad 500$

$96,97,98,99,100$ y 101. Seis cuadritos, copia del Bassano ${ }^{376} \quad 480$

202.920

${ }^{373}$ A entrada do catálogo da Bemposta refere com o n.o 14 - "Um dito em pano, representando as Cascatas do Tivoli junto a Roma em 1813, por Mr. Alovres [...]", adquirido pelo Snr. Conselheiro João da Cunha Araújo. ANTT, Casa Real, Cx. 7311, maço 91, sendo apenas mencionada uma pintura naquele lote. 374 Das obras que foram à praça na Bemposta, não foi possível localizar esta representação. Teria permanecido nas colecções régias? No Palácio Nacional da Ajuda localizamos uma pintura a óleo sobre tela - "Cristo com a Cruz", $\mathrm{n}$ o inv. $491 \quad \mathrm{P}$, http://www.matriznet.dgpc.pt/MatrizNet/Objectos/ObjectosConsultar.aspx?ldReg=992404, consulta online, Dezembro 2018, que teria pertencido à Galeria de Pintura do rei D. Luís. No entanto, no "Álbum de caricaturas do Rei D.Luís", vem escrito debaixo da foto da pintura "Comprado em Lisboa". Hugo Xavier afirma tratar-se de obra sobre madeira, atribuída a Andrea del Sarto. V. XAVIER, Hugo, obra citada, p. 320, o que torna contraditória a informação.

${ }^{375}$ Esta obra pode ser a que vem referida no catálogo do leilão da Bemposta com o n. 22, com um título semelhante - "Um quadro pintado em taboa, representando um paiz e figuras do facto Historico, Lot e duas filhas, largura um palmo e meio, altura um, moldura dourada", com um valor de $1 \$ 000$. Foi adquirido pelo Sr. António Borges da Câmara, por 3\$800, no dia 23 de Maio de 1848. ANTT, Casa Real, Cx. 7311, maço 91. No Palácio Nacional da Ajuda existe, no acervo, uma pintura de igual representação - "Lot e as Filhas", óleo s. tela, atribuída a Parmigiano, Girolamo F. M. Mazzola, (1503-1540), inv. N.o $484 \mathrm{P}$.

376 No catálogo da Bemposta a entrada com o n.o 53 tem a seguinte descrição - "seis ditos com o mesmo numero, representando Historia Sacra, cópia de um Escolar de Bassano, largura um palmo e um quarto, altura um dito, molduras douradas", com um valor base de $28 \$ 000$. Foram adquiridas no dia 23 de Maio de 1848, pelo Sr. João Rodrigues Blanco, pela quantia de 32\$600. ANTT, Casa Real, Cx. 7311, maço 91. 
Resumen General:

Valor liquido e reales von.mrs

Total

En Pinturas

135.280.

En Joyas y Alajas

509.909

En metálico

666.666. $222 / 3$

Madrid 30 marzo de 1826. Pedro de Bargas - Francisco Scarlati de Robles - Sebastiano Hurtado. - Recibi las Pinturas y alhajas que anteceden y para que conste firmo en Madrid à cuatro de Abril de mil ochocientos veinte y seis- M El Duque de Montemar Conde de Garciez".

Assim, no lote de D. Carlota, a pintura de temática religiosa dominava o conjunto, com 65 pinturas $(47,7 \%)$, seguindo-se as paisagens com 44 pinturas $(32,2 \%)$, a pintura de género representada com 22 obras $(16,1 \%)$ e os retratos em número de $5(3,67 \%)$, o que manifesta não só uma apetência para a aquisição de pintura de carácter devocional, compatível com a centralidade das práticas religiosas no antigo regime, como a maior disponibilidade no mercado de arte italiano de obras de temática religiosa, como já foi anteriormente salientado.

Chegadas. Este conjunto de pinturas proveniente de Roma, com passagem por Madrid, não chegaria a Portugal antes do fim de 1826, pois só a partir de 1 de Abril, daquele ano, se comunicava aos representantes dos herdeiros que se iria proceder à entrega dos lotes relativos "à repartição dos bens da herança de Carlos IV e Maria Luísa de Parma, processo esse atribulado pelas exigências de Fernando VII, irmão da Rainha portuguesa, que pretendia ser reembolsado pelas despesas que efectuara com as pensões e mesadas que abonara a seus pais no exílio (período de Marselha de 1809-1812 e de Roma de 1812-1819)" e gastos que efectuara "após a morte de ambos, o que absorveria a quase totalidade da herança" ${ }^{377}$, pretensão essa que fora, então, contestada pelos restantes co-herdeiros.

Pela documentação citada, de entre ela as já mencionadas Memórias [...] de Presas, ou a correspondência diplomática a que refere Celina Bastos ${ }^{378}$, sabemos que em 1828 havia ainda

377 CHECA, Carmen García-Frías, "Nuevas aportaciones al estúdio de la colección pictórica de Carlos IV en el exilio", in Carlos IV y el arte de su reinado, Actas de las Jornadas de Arte e Iconografia, Fundación Universitaria Española, Outubro 2011, pp. 215 e 232; BASTOS, Celina, obra citada, MNAA, 2014, pp. 1011.

${ }^{378}$ BASTOS, Celina, obra citada, 2011, pp. 242-243. 
notícia das pinturas estarem em Espanha. A totalidade, ou uma parcela, não sabemos com toda a certeza.

A chegada das pinturas provenientes de Espanha foi um acontecimento de uma importância capital, pois significava a incorporação nas colecções de que a soberana portuguesa já dispunha, e pelas quais já se destacara a sua residência do Ramalhão, de um conjunto de pinturas, algumas de mérito artístico incontestável e que sobressaem nas colecções dos museus nacionais. 


\section{VIII - Trocas, dúvidas e interrogações. Teatros de Sombra e Luz. O Momento Histórico}

Trocas. De seus pais herdara D. Carlota Joaquina cento e trinta e seis pinturas, devendo a este número serem descontadas a da autoria de Theodor Michaijlovic Matveev, identificada com o n. 49 - “Un Pais, por Teodoro Malwef” que, como já escrevemos, não veio para Lisboa, pois Carmen G. F. Checa identifica-a no Escorial (com o n.o Inv. 10032376), na sequência de trocas que terão existido entre os lotes dos diferentes co-herdeiros, ou ainda e simplesmente, motivadas por algum descuido pois, segundo aquela autora "el almacenaje provisional en el Palacio Real de Madrid se hizo de forma bastante acumulativa y sin numeración, lo que pudo provocar el que se quedaran algunos quadros en el citado Palacio ${ }^{379 \prime}$. O mesmo descuido refere Presas, no que respeita à guarda e conservação das pinturas, o que teria, de igual modo, justificado o desvio da obra atribuída a Rosa de Tivoli ${ }^{380}$, conforme comprova o documento da Biblioteca da Ajuda, já citado ${ }^{381}$.

A possibilidade de terem existido trocas entre os diferentes lotes, apesar de não existir menção de tal na documentação por nós consultada, parece ser um facto consumado, como refere Checa no seu estudo, afirmação essa amplamente documentada pela autora ${ }^{382}$.

Considerando as permutas que existiram e que, pelo menos, duas valorizadas pinturas do quinhão hereditário de D. Carlota Joaquina, a pintura de Rosa Tivoli (n. 310 da Relação), roubada das cavalariças do Duque de Montemar, e a obra do pintor russo Theodor Matveev ( .ㅇ 49 da Relação), ter sido deslocada para o Museu das Belas Artes de Madrid e que, ambas, assumidamente não chegaram a Lisboa, julgamos ser provável que outras as viessem substituir, facto que se torna plausível, pois sabemos que os representantes de D. Carlota Joaquina se envolveram activamente no processo de obtenção das obras que compunham o quinhão hereditário da Rainha de Portuga| ${ }^{383}$.

Em síntese, apresentamos informação que permite concluir que nem todas as pinturas que integravam as colecções de D. Carlota Joaquina teriam sido leiloadas na Bemposta e, sabemos, pelos dados apresentados, que terão existido trocas entre os lotes correspondentes à herança

379 CHECA, Carmen García-Frías, Nuevas Aportaciones al Estudio [...], 2011, pp. 230 e 242.

380 PRESAS, José, Memórias Secretas de la Princesa del Brasil, actual Reina viúda de Portugal, La Señora Doña Carlota Joaquina de Bourbon, Burdeos, 1830, p. 277. V. BASTOS, Celina, "Percurso de uma Pintura", in Luca Giordano Extase de S. Fancisco, MNAA, 2014, p. 13.

${ }^{381}$ BA 54-X-33 (7a).

382 CHECA, Carmen García-Frías, obra citada, 2011, p. 242.

383 BASTOS, Celina, 2014, pp. 10-11. 
dos reis-pais, Carlos IV e Maria Luísa de Parma, pelo que, em consequência, deduzimos que, no que respeita à quota-parte de D. Carlota Joaquina, outras pinturas tivessem vindo compensar as que nunca teriam chegado a Lisboa.

Dúvidas e Interrogações. Persistem, no entanto, dúvidas quanto às obras de arte que poderiam ter substituído as que, apesar de pertecerem ao quinhão da Rainha-viúva, nunca lhe foram entregues.

Seguindo o mesmo raciocínio, apresentamos a hipótese de a pintura "Santa Face", que atualmente se encontra na Capela da Rainha, do Palácio Nacional da Ajuda, n.o inv. 41573 P, atribuída a Theotokopoulos, Domenikos, (El Greco) (1541-1614), autor que fizera a carreira artística em Espanha, ser a que consta na Relação das obras vindas de Roma, para Espanha, com o "no 465. Una cabeza de Jesucristo pintada por Domingo Greco, de buen tiempo", fazendo parte da herança dos monarcas espanhóis, mas não da quota hereditária da Rainhaviúva de Portugal. Esta seria uma das poucas pinturas espanholas existentes na colecção dos reis-pais em Roma, descrita como original de Greco "del buen tiempo", com as dimensões de 1 pé e 11 polegadas de altura e 1 pé e 5 polegadas ao baixo, semelhantes às dimensões da pintura da $A_{j u d a}{ }^{384}$. Isto é, as dimensões equivalentes às da pintura da Ajuda, estando, no entanto, trocadas as da altura, com as do comprimento. Considerando que o inventário das 688 pinturas foi feito em 20 dias, não é improvável que as medidas, tiradas de um modo apressado, fossem anotadas com esta troca, não tendo em conta a correcta leitura do tema tratado. Curiosamente, diz Checa, em nota de rodapé, relativamente a esta obra "que podría entenderse que fuera un Cristo, Salvador del mundo, pero entre los que se conservan, no existe ninguno con estas dimensiones" ${ }^{\prime 35}$, não a relacionando com a pintura do Palácio da Ajuda, eventualmente por não integrar a lista denominada "Tercera Division [...]"386, que coubera à Rainha-viúva de Portugal. Consideramos, pelas razões atrás apontadas, que esta poderia ter integrado aquele lote por permuta, conforme aquela autora afirma ter acontecido entre os lotes destinados aos outros co-herdeiros.

\footnotetext{
${ }^{384}$ CHECA, Carmen García-Frías, 2011, p. 226.

${ }^{385}$ CHECA, Carmen García-Frías, 2011, p. 226.

${ }^{386}$ BA 54-X-33 (7).
} 


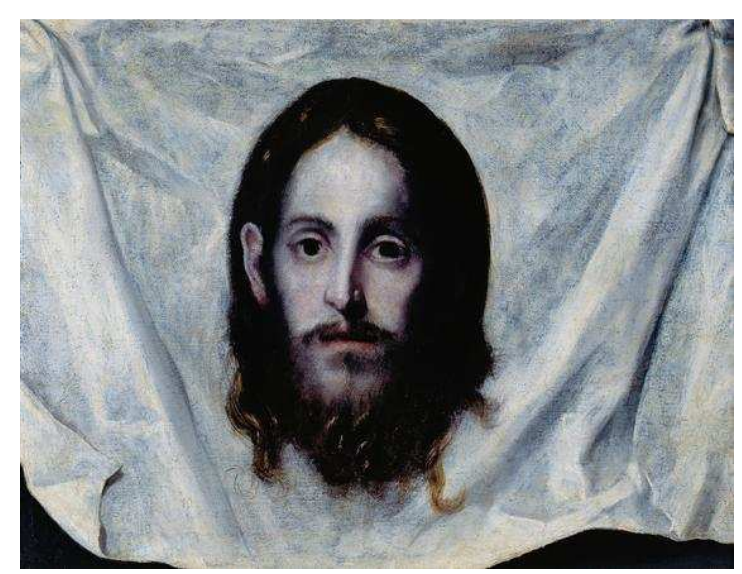

Santa Face, Theotokopoulos, Domenikos, (El Greco) (1541-1614), n.o inv. 41573 PNA ${ }^{387}$. Da herança dos reis Carlos IV e Maria Luísa, fazia parte uma pintura "una cabeza de Cristo", original de Greco, reproduzindo o mesmo tema da pintura das colecções do Palácio da Ajuda. Esta é considerada como única daquele autor existente em Portugal.

Luís de Moura Sobral, na entrada que dedica em catálogo (1995) a esta pintura, afirma “ignora-se a sua proveniência exacta, assim como a data da sua chegada ao Palácio" ${ }^{388}$, e Hugo Xavier refere-a no conjunto das pinturas que integraram a Galeria de Pintura do Rei D. Luís, na segunda sala, dedicada aos "Quadros antigos", não avançando, de igual modo, nenhuma informação relativa ao modo como teria sido efectuada a sua incorporação naquela colecção ${ }^{389}$. O "silêncio" que rodeia esta pintura, isto é, a ausência de informação ou documentação que refira a sua aquisição, ou modo de incorporação nas colecções reais, torna ainda mais plausível a proposta que aqui apresentamos.

\footnotetext{
${ }^{387}$ http://www.matriznet.dgpc.pt/MatrizNet/Objectos/ObjectosListar.aspx?TipoPesq=4\&NumPag=1\&Re $\mathrm{gPag}=50 \&$ Modo $=1 \&$ DenTit=Santa+Face\&NumInv=41573\&BaseDados=30\&ldAutor=. Consulta online Janeiro de 2019.

${ }^{388}$ SOBRAL, Luís de Moura, A Pintura Maneirista em Portugal, Arte no tempo de Camões, coordenação científica Vitor Serrão, Comissão Nacional para a Comemoração dos Descobrimentos Portugueses, Lisboa, 1995, p. 315.

389 XAVIER, Hugo, Galeria de Pintura no Real Paço da Ajuda, Imprensa Nacional-Casa da Moeda, 2013, p. 256.
} 


\section{IX - O Momento Histórico. De Rainha consorte a Rainha-viúva. O novo papel de D. Carlota Joaquina na corte portuguesa. "A Santa Face". De Roma a Lisboa?}

Revolução e Contra-revolução. O período histórico em que decorrem as negociações finais relativas às partilhas dos Reis de Espanha, e a chegada das obras a Portugal, corresponde ao momento em que, após a morte do rei D. João VI, ocorrida no ano de 1826, a Rainha, entretanto viúva, se envolve no apoio às forças "apostólicas", patrocinando as aspirações políticas de seu filho D. Miguel (1802-1866), opondo-se às Cortes, à diminuição do poder real, em síntese, ao Liberalismo.

Diz-nos Oliveira Martins que, instalando-se "no seio da Corte onde readquiriria o seu lugar"390, D. Carlota Joaquina, agora na posse da herança do marido, será até à data da sua morte, em 1830, a "divindade tutelar do absolutismo", despendendo na afirmação daquela causa e na legitimação das aspirações ao trono de D. Miguel, as quantias que herdara. Rainha que o próprio marido desterrara e condenara ao exílio, viu-se por morte deste "esbulhada" da Regência, a favor da filha D. Isabel Maria, mas não da metade do tesouro que por direito receberia: "50 milhões de cruzados em dinheiro, mais 4 em ouro em pó e barra, e não se sabe quanto em brilhantes do Brasil" ${ }^{391}$. Às verbas herdadas do marido somavam-se, por aqueles anos, as que herdara de seus pais. Era rica num país empobrecido por invasões estrangeiras, guerras civis e lutas fratricidas. A expulsão das tropas francesas tinha custado cara ao erário público, a independência do Brasil dera outra machadada nos interesses económicos portugueses, pelo que o dinheiro de que dispunha, investido na causa "apostólica", em muito ajudaria ao triunfo da mesma, ainda que temporário.

Num país empobrecido, traço fundamental da sociedade portuguesa de então, era ao partido liberal que a população atribuía boa parte da responsabilidade pelo estado de penúria em que se encontrava, pelo que, quando D. Miguel desembarca em Belém, em 22 de Fevereiro de 1828, dando início a um período histórico em que assumiu a governação do país (1828-1834), diz Oliveira Martins que "havia um entusiasmo decidido, uma aclamação espontânea, um furor desenfreado", pois, "ninguém era mais nosso do que D. Miguel, e por isso foi o último dos que o povo compreendeu e amou"392.

\footnotetext{
390 MARTINS, Oliveira, Portugal Contemporâneo, Vol. I, Lello e Irmão Editores, Porto, 1981, p. 117.

391 MARTINS, Oliveira, obra citada, 1981, p. 39.

392 MARTINS, Oliveira, obra citada, 1981, p. 78.
} 
Com o regresso de D. Miguel, gorados os intentos de chamar a si o governo, D. Carlota investe no filho que quis "com exaltação e vaidade", "vendo-se nele moralmente reproduzida, por ele compreendida e por intermédio dele, vingada". Segundo o autor do Portugal Contemporâneo ela, que procurara no reinado de seu marido "substitui-lo no mando, legal ou ilegalmente" ${ }^{393}$, apoiaria incondicionalmente o miguelismo, entre 1828-1830, morrendo com a satisfação de ver no trono o "filho querido, discípulo amado, servo submisso"394, "instrumento dócil”395, defensor extremado dos ideais absolutistas que, com sua Mãe, professara.

Instalada no Palácio Real da Ajuda, onde acompanha todas as movimentações políticas, é provável que na ocasião da chegada a Portugal das pinturas que herdara de seu pais, o que só deverá ter ocorrido por volta do início de 1828, a Rainha-viúva ali se encontrasse. Uma carta, por si assinada, datada de "Ajuda 15 de maio de $1828^{\prime 396}$, que dirige à Infanta D. Ana de Jesus, Marquesa de Loulé (1806-1857), que na ocasião se encontrava em Paris, assim o parece confirmar.

É plausível que a soberana quisesse ter junto de si obras de arte que lhe invocassem a sua terra natal, pois é conviç̧ão dos historiadores que foi sempre espanhola de coração, tanto mais que no país onde era rainha, sentira por muitas vezes as agruras do exílio e da solidão. Como católica, "religiosa sin superstición", como a definira Casa Irujo, embaixador de Espanha na corte do Rio de Janeiro, a "Santa Face", obra de carácter devocional, permitiria satisfazer a dimensão privada da prática religiosa, bem como ter junto de si uma obra de arte excepcional que pertencera a seus pais, no exílio que eles próprios também haviam experimentado, nos tempos de Marselha e de Roma. Era uma aproximação à sua terra natal, através da obra de um artista que, apesar de estrangeiro, interpretara de um modo singular as profundezas do catolicismo em Espanha, imprimindo à sua pintura uma teatralidade próxima da imagética da contra-reforma tridentina.

Vimos como no Ramalhão, nos aposentos da então Princesa do Brasil, se localizava um altar portátil que continha uma representação de Santo António de que os franceses, durante a

393 Idem, ibidem, p. 176.

${ }^{394}$ LIMA, Oliveira, D. João VI, no Brasil, ACD Editores, s/data, p. 177.

395 MARTINS, Oliveira, Portugal Contemporâneo, 1981, pp. 39 e 70.

396 PEREIRA, Ângelo, As Senhoras Infantas Filhas D'El Rei D. João VI, Editorial Labor, Lisboa, 1938, pp. 158-159. Na mesma obra, uma carta de D. Miguel à mesma Infanta, sua irmã, é datada do Palácio de N. S. d'Ajuda, 8 de Março de 1828", o que confirma a sua presença naquele Palácio Real. Obra citada p. 158. 
ocupação das tropas napoleónicas, se teriam apoderado. Nos inventários posteriores, nomeadamente no inventário de 1829, é descrito, nos aposentos privados, um "Hum Altar portátil de Espinheiro com a firma de Sua Magestade gravada em prata e Pedra Ara quatro frontais Trez Casullas Tres bolças de Corpurais [...]"397, confirmando quanto a devoção privada pautava o quotidiano de uma corte profundamente católica.

A "Santa Face" pode, durante escasso tempo, pois a soberana morre pouco tempo depois da chegada das pinturas de Espanha, ter satisfeito a espiritualidade de quem sentia as forças físicas a abandonarem-na, em consequência das muitas contrariedades, achaques e doenças de que sofria.

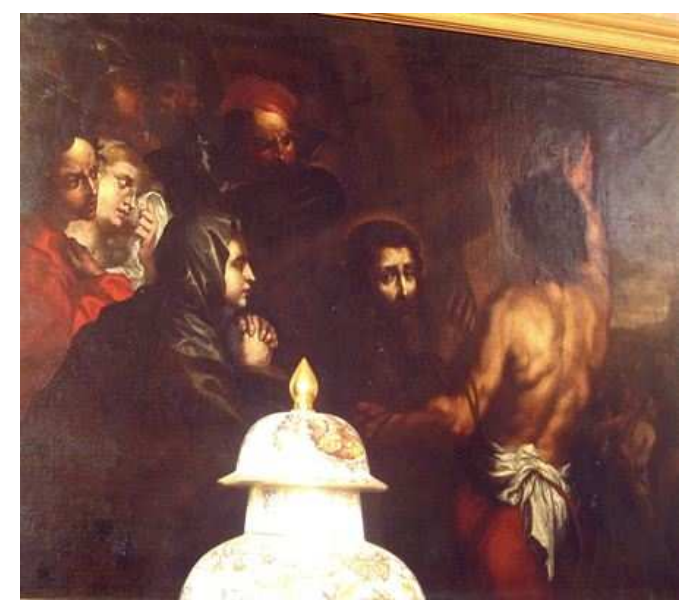

Cristo a caminho do calvário, inv. 492 PNA, autor desconhecido, sendo nos catálogos da Galeria de Pintura do rei D. Luís, de 1869 e 1872, atribuído a escola Alemã ${ }^{398}$.

Uma outra pintura que, de igual modo, se encontra no acervo do Palácio da Ajuda, Cristo a caminho do calvário, n.o inv. 492, (alt. $97 \mathrm{~cm} \times 129 \mathrm{~cm}$ ), de autor desconhecido, que integrou o acervo da antiga Galeria de Pintura do rei D. Luís, figurando nos catálogos de 1869 e 1872, respectivamente com os números 95 e 112, então atribuída à Escola Alemã, julgamos poder tratar-se da obra que tinha o n.o 306, no manuscrito "Tercera Division"399, adjudicada a D. Carlota Joaquina nas partilhas de seus pais, com a mesma denominação - "El Calbario, de Escuela Alemana", então avaliado em 1.000r.s. No catálogo do leilão da Bemposta encontramos dois Calvários, um atribuído a "um discípulo de Rubens", em cobre, com o n.으 131; outro, da "Escola de Rubens", em tábua, que foi adquirido pelo sr. António Borges da

\footnotetext{
${ }^{397}$ ANTT Casa Real, 387, Cx. 3703.

${ }^{398}$ http://www.matriznet.dgpc.pt/MatrizNet/Objectos/ObjectosConsultar.aspx?ldReg=992405. Consulta online Agosto de 2019.

${ }^{399}$ BA 54-X-33 (7).
} 
Câmara ${ }^{400}$. $O$ facto de o manuscrito da Biblioteca da Ajuda não mencionar as dimensões, nem demais informação técnica, nem termos logrado obter cópias dos documentos de Espanha, permite-nos, apenas, deixar esta hipótese de trabalho ${ }^{401}$.

O caminho percorrido por outras pinturas, tanto as provenientes da quota hereditária, como as que D. Carlota Joaquina anteriormente possuíra nas suas colecções, boa parte dispersa na sequência dos leilões realizados no Palácio da Bemposta, após Dezembro de 1847, torna difícil agora definir, com exatidão, os seus actuais paradeiros, com excepção para as vinte e cinco pinturas adquiridas pelo governo português e que vieram posteriormente a integrar as coleções públicas nacionais.

Em síntese é, assim, possível estabelecer uma ligação entre alguns títulos inscritos na "Tercera Division" ${ }^{402}$, relativa à parte que coube em partilhas à Rainha de Portugal, por morte dos Reis Carlos IV e Maria Luísa de Borbón Parma, e algumas das pinturas que integravam o catálogo do leilão da Bemposta. Alguns títulos e atribuições reproduzem, de perto, os daquela lista, assumindo as autorias ali propostas. Outras, não logramos localizar naquele catálogo, o que reforça a ideia de que nem toda a colecção de pintura de D. Carlota Joaquina terá sido dispersa no leilão por, provavelmente, não se encontrar, na totalidade, no Paço do Ramalhão, aquando da realização dos inventariários post-mortem. Decorre desse facto ser plausível que algumas obras que integraram o "Gabinete" de pintura de D. Carlota Joaquina ainda se encontrem nos Palácios que foram residências régias, até ao fim da Monarquia.

É ainda de salientar em documentação relacionada com o espólio da Imperatriz-Rainha, a referência a objectos no Palácio das Necessidades, conforme "Resumo do Inventário de S. M. Imp. e Real A Snr.a D. Carlota Joaq. de Bourbon", datado de Abril e Maio de 1835403, nomeadamente "móveis", "roupas", "relógios", "paramentos" e "louças". A possibilidade de uma vez para ali deslocadas, durante o reinado de D. Maria II, ali terem permanecido, assim escapando ao leilão, parece plausível. De igual modo deveremos ter em conta a possibilidade de os herdeiros da Imperatriz.Rainha terem adquirido obras no leilão, pois são referenciados

\footnotetext{
${ }^{400}$ ANTT, Casa Real, Cx. 7311, maço 91.

${ }^{401}$ De igual modo encontra-se nas colecções do Palácio Nacional da Ajuda uma pintura "A Buena-Dicha", inv. 4808 P., atribuída a Moise Valentin, que teria integrado a colecção da Galeria de Pintura do Rei D. Luís. (Hugo Xavier, obra citada, p. 230). Curiosamente, na lista das obras que pertenciam aos Reis Carlos IV e Maria Luísa de Parma e foram herdadas pelos seus filhos, aparece, com o n.o 129 - "Una gitana diciendo la buena ventura a un joven, estilo del Caravaggio, alto 5 pies 8 pulgadas, ancho 4 pies 4 pulgadas", considerada entre os quadros classificados como "Mediano". Checa, obra citada p. 222, que poderia corresponder a esta obra. Esta hipótese terá que ser mais aprofundada.

${ }^{402}$ BA 54-X-33 (7).

${ }^{403}$ ANTT, Casa Real, Cx. 6523.
} 
recibos em nome dos representantes dos augustos co-herdeiros, como fomos assinalando em nota ${ }^{404}$.

${ }^{404}$ Ver ANTT, Casa Real, Cx. 6523, lista dos representantes dos Infantes herdeiros. 


\section{X — Partilhas, Dívidas e Leilões}

o Testamento. Por morte da Imperatriz.Rainha que ocorre em 7 de Janeiro de 1830 e por vontade testamentária ${ }^{405}$, D. Carlota Joaquina deixara o seu "Palacio do Ramalhão, com todos os moveis que dentro delle se achão, de qualquer género ou qualidade que sejão, juntamente com as suas duas Quintas, terras e mais fazendas que Ihe pertencem, ao Meu muito Amado e Prezado Filho El Rey D. Miguel [...]", não esquecendo diversos servidores, bem como os credores e as dívidas junto deles contraídas, e que deveriam ser "satisfeitas à vista dos roes" que os mesmos apresentassem.

Aquela disposição viria, pouco tempo depois da morte da Imperatriz-Rainha, a ser posta em causa e impugnada, na sequência da Convenção de Évora-Monte, de 1834, que afastaria D. Miguel (1802-1866) da Coroa e do Reino e o impediria de entrar no país.

O inventário e avaliação do legado, nomeadamente do espólio do Palácio do Ramalhão, para efeitos de partilhas ${ }^{406}$ e pagamento das dívidas reclamadas, bem como a posição de D. Miguel enquanto co-herdeiro, fizeram arrastar este processo pois, só em 1847, se daria início à hasta pública no Palácio da Bemposta, com direito a catálogo impresso ${ }^{407}$. Ainda em 1844, uma extensa alegação, datada de 10 de Fevereiro, referia "a longa história do processo" que começara "pelo despacho que excluio o Senhor D. Miguel da sua quota hereditária, devolvendo-a para os Augustos Colaterais" ${ }^{408}$, determinado pela Lei de 19 de Dezembro de 1834, à luz da qual o infante "fora privado de sua herança". Argumentava João de Deos Antunes Pinto, advogado da Casa Real, contra a venda dos bens sem antes "ser decidida a questão sobre a audiência do Senhor D. Miguel o que, aliás, fora aprovado após "um longo conselho de família [...] onde se reconheceu a necessidade de ser citado o Senhor D. Miguel", para a aplicação daquela pena. Afirmava-se então que, sob pena de nulidade do processo, se deveria proceder àquela formalidade, isto é, "não instarmos pela venda, antes de ser decidida

\footnotetext{
${ }^{405}$ ANTT, PT-TT-GAV-16-3-18. Agradeço ao Arquitecto Jorge Brito e Abreu a generosa oferta de uma cópia daquele documento, em momento inicial deste estudo.

${ }^{406}$ ANTT, Casa Real, Cx. 6523.

407 Relação dos Quadros pertencentes á Herança da Imperatriz Rainha a Senhora D. Carlota Joaquina de Bourbon, hoje existentes no Real Palacio da Bemposta, onde hão-de ser vendidos em hasta publica, perante o Juiz do respectivo Inventario [...] e que forão descriptos e avaliados pelos Senhores António Manoel da Fonseca, Lente de Pintura Histórica da Academia das Bellas Artes de Lisboa, e Luiz Tirinnanzi, Pintor restaurador de quadros [...], assinado pelo Solicitador da Caza Real, Francisco de Caldas Aulete, Lisboa, 1843.

${ }^{408}$ ANTT, Casa Real, Cx. 7100, XX/2/81 (8).
} 
a questão sobre a audiência do Snr. D. Miguel" ${ }^{\text {"09 }}$. E que, uma vez feita a citação "do referido auzente o Snr. D. Miguel requerida pelo Curador [...] e de que se tratou no Conselho de Família [...]", passava a efectiva a decisão. Em 19 de Novembro de 1846, documentação deste processo guardada no ANTT, dá notícia do recurso da sentença que colocava D. Miguel "na posição e classe dos banidos que morrera civilmente" e, em consequência, devolvera "a sucessão [...] aos seus Augustos e Reaes Collateraes" ${ }^{\prime 10}$. A decisão de contestar o juiz que assim decidira uma "questão impertinentemente suscitada pelo Curador Geral no processo sumario d'hum inventario [...]", levara a revogação daquele despacho, sendo determinado "[...] prosseguir o [...] inventario seus termos, continuando a figurar n'elle o Auzente o Snr. D. Miguel, na mesma qualidade com que foi declarado pela Augusta Cabeça de Cazal, e com o Curador nomeado à sua Quota Hereditária, [...]. Lisboa, 19 de Novembro de 1846. Alves de SáBaptista Lisboa. Tem Tenção do Juiz Ferrão" ${ }^{\prime 11}$. A defesa de D. Miguel assentava na contestação ao propósito de o privar, na sequência da Lei de 19 de Dezembro de 1834, de "direitos que já estavão adquiridos" à data, pelo "direito hereditário", pois sua mãe morrera em $1830^{412}$, data anterior à "Lei do Banimento".

Dívidas. Entre a questão jurídica sobre os direitos de D. Miguel e a avaliação do espólio da herança, o tempo decorria, aos filhos sucediam os netos na habilitação hereditária e, a estes, como por morte de D. Maria II (+1853), os seus maridos e descendentes. A lista dos credores e respectivas quantias fora estabilizada e lá constavam nomes como o Conde de Farrobo, com direito a créditos por "letras e obrigações", os herdeiros do Conde da Póvoa, por "empréstimo de obrigação", João Paulo de Almeida Grandella, por "géneros de Merciaria", Firmina das Dores, por "Fazendas vendidas próprias de contrabandista" [sic], Francisco Roza, por "Géneros de Sirgueiro", João Baptista Ardisson, por "pagamentos que fez por ordem da finada"413, entre outros nomes, como Miguel Jozé Deniz, pelo saldo de "huma banqueta de prata"114.

\footnotetext{
${ }^{409}$ ANTT, Casa Real, Cx. 7100, XX/2/81 (8).

410 Idem, idem.

${ }^{411}$ ANTT, Casa Real, Cx. 6523. Docs sobre posição de D. Miguel perante a Lei de 19 de Dezembro de 1834. 412 ANTT, Casa Real, Cx. 7100, XX/Z/81(8). Documentos sobre o processo relativo aos direitos hereditários de $\mathrm{D}$. Miguel.

${ }^{413} \mathrm{~V}$. "Mistérios e Viagens de um manuscrito: A Factura de los acopios q. 9 Dn. Jn. B.ta Ardisson ha hecho en Paris p. $\underline{a}$ la Guarda Ropa de S. M. M. la Reyna N.S., y Sr. Infanta D. M. $\underline{a}$ Franc. $\underline{a}$ de Asis. Paris 1816. 40 \&", blog da Biblioteca da Ajuda, editado em Março de 2018.

${ }^{414}$ ANTT, Casa Real, Cx. 6523.
} 


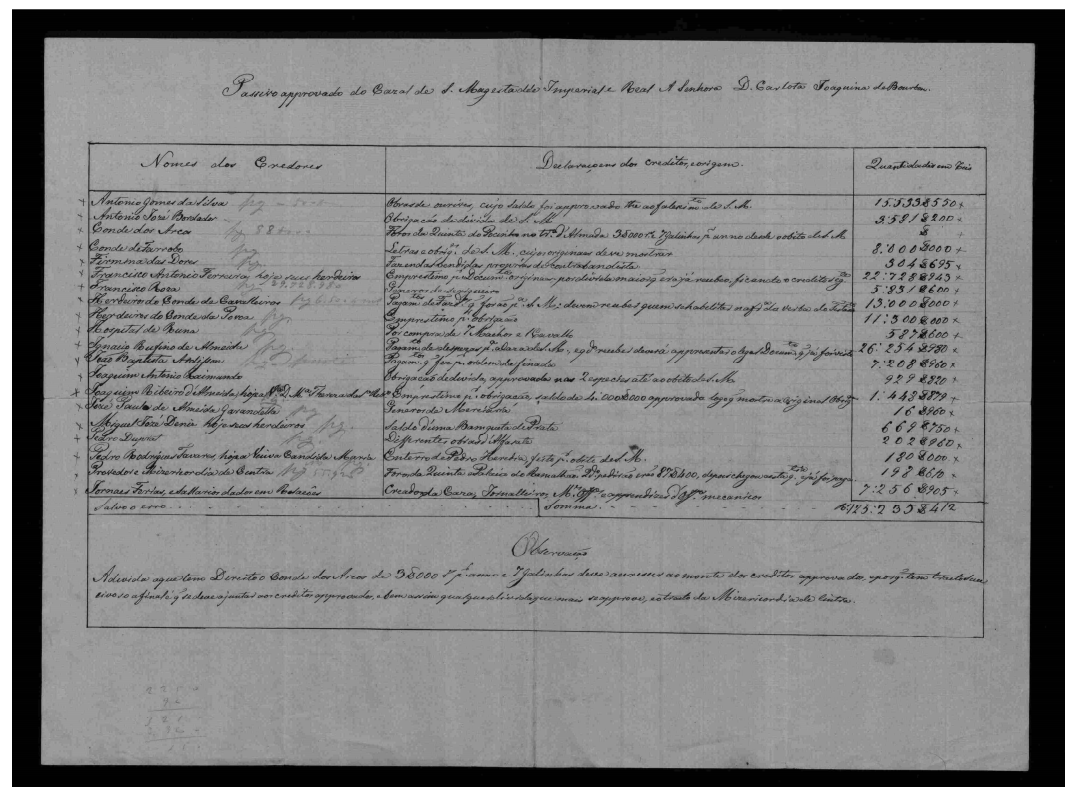

"Passivo approvado do Cazal de S. Magestade Imperial e Real A Senhora D. Carlota Joaquina de Bourbon" ANTT, Casa Real Cx. 6523

Conforme demonstra o documento relativo ao "Passivo approvado do Cazal de S. Magestade Imperial e Real A Senhora D. Carlota Joaquina de Bourbon", as dívidas andavam pelos 125.235\$412rs., enquanto o valor inscrito no “Resumo do Invento de S. M. Imp. E Real a Snr.a D. Carlota Joaq.a de Bourbon" totalizava os $165.323 \$ 611$ rs. Do legado da Imperatriz-Rainha, entre os activos e o passivo resultava, pois, um pequeno saldo positivo ${ }^{415}$.

Assim, da avaliação efectuada, datada dos meses de Março, Abril e Maio de 1835, verificamos que a "Quinta do Ramalhão e suas pertenças" valiam 49.710\$000, as “Apólices" 59.550\$00, os “Quadros da Qta do Ram.ão", 9.821\$160, a “Mobília da dita”, 5.301\$780, os “Objectos da Ermida da d.ta $-2.061 \$ 580$ ", os “Paramentos - 3.099\$000", a "Prata $-14.440 \$ 121$ ", entre diversos outros valores que totalizavam os $165.323 \$ 611$ réis, inscritos no “Resumo do Invent.o de S.M.Imp.e Real a Snr.a D. Carlota Joaquina de Bourbon" ${ }^{\prime 16}$.

Importa aqui assinalar que neste, como em outros inventários, o núcleo relativo às pratas constituía o mais valioso do conjunto, ultrapassando o valor atribuído ao da pintura. E esta será uma constante nas relações de bens inscritos nos inventários orfanológicos que consultámos, sendo um traço marcante na caracterização do património das elites do Antigo Regime, em Portugal. Curiosamente não são mencionadas jóias nesta avaliação, apesar de

\footnotetext{
${ }^{415}$ ANTT, Casa Real, Cx. 6523.

${ }^{416}$ ANTT, Casa Real, Cx. 6523.
} 
sabermos que de Espanha veio um conjunto de valor assinalável, proveniente da herança paterna ${ }^{417}$.

Após um longo processo, durante o qual se discutiram e disputaram direitos hereditários, inventários e avaliações, os objectos que anteriormente constituíam o recheio de uma das mais ricas casas senhoriais portuguesas do início de oitocentos, seriam dispersos nas diversas almoedas que decorreram no Palácio da Bemposta, que iniciadas em Dezembro de 1847, se desenrolaram pelos anos seguintes.

${ }^{417}$ BA 54-X-33 (13). 
XI - Reavaliação de um legado. As colecções de D. Carlota Joaquina de Bourbon. Coleccionador, "connoisseur", amador.

Apesar dos testemunhos materiais, presentes tanto em Portugal como no Brasil, um historiador com a importância de José-Augusto França, para o estudo da História da Arte e da História Social da Arte em Portugal, não deixa de tecer críticas quanto ao papel de D. Carlota Joaquina e ao de seu augusto esposo, o Rei D. João VI, no que refere ao coleccionismo de arte, ou ao patronato artístico, durante o seu reinado. Aquele historiador salienta, essencialmente, quer o papel dos embaixadores, quer a accção do grupo social enriquecido com as medidas de Pombal, tanto no Antigo Regime, como durante o Liberalismo, passando por este período sem atribuir especial importância ao legado daqueles soberanos. Bem sabemos que a permanência da corte no Rio de Janeiro (1807-1821), o interregno brasileiro, foi responsável pela dispersão dos testemunhos, tanto artísticos como documentais, dificultando a acção dos que quisessem abrir novos trilhos e perspectivas no estudo do coleccionismo e dos seus agentes, em Portugal, no final do Antigo Regime.

José-Augusto França ${ }^{418}$ relativamente à colecção de pintura que a rainha D. Carlota Joaquina deixou na Quinta do Ramalhão, citando a Revista $O$ Panorama ${ }^{419}$ na qual se escreve "foi leiloada, em 44 - no meio de grandes alarmes patrióticos", suscitados por todos aqueles que não queriam ver "sair do Tejo o navio que transportaria para Inglaterra estes quadros de grandes mestres", diz que "não o seriam", baseando-se nos relatos do conde Athanasius Raczynski (1788-1874) ${ }^{420}$ que assegurara, os tinha examinado de perto e recusara "lisonjeiras atribuições ao Domenichino, ao Guercino, a Salvatore Rosa [...]". Para França, tanto as compras que D. João VI efectuara, como as obras que D. Carlota Joaquina possuía, resultariam de "compras ocasionais e sem programa", cujo resultado se veria nas obras que foram leiloadas na Bemposta. Ora, se Raczynski não faz, de facto, um elogio rasgado à totalidade das pinturas então expostas no Palácio da Bemposta, em tempo que antecedeu o leilão, não deixa de reconhecer mérito a muitas das obras que aí observou. Veja-se o julgamento sobre as duas marinhas de Vernet - "Je suis tenté de croire que ces tableaux sont en effet des originaux, et

\footnotetext{
${ }^{418}$ FRANÇA, José-Augusto, Arte em Portugal no século XIX, I volume, Bertrand Editora, 3.a edição, 1990, p. 191.

${ }^{419}$ O Panorama, n.o 109, 27 de Janeiro de 1844.

${ }^{420}$ RACZYNSKI, Le Comte, Les Arts en Portugal, Lettres Adresssés A la Société Artistique et Scientifique de Berlin et accompagnées de documens, Paris, 1846, pp. 280-283. Athanasius Raczinsky (1788-1874) foi ministro do rei da Prússia na corte portuguesa, onde chegou em Maio de 1842 e permaneceu até 1848. Erudito e amante das Artes dedicou uma parte do tempo no nosso país a expedições educativas, ao estudo e à escrita com a qual pretendeu dar a conhecer a História e a especificidade da Arte portuguesas.
} 
dans ce cas, ils auraient une valeur commerciale assez grande. Je les trouve dans tous les cas três bons" ${ }^{\prime 21}$. E, mesmo questionando muitas das atribuições apresentadas no artigo daquela revista, considerando-as erróneas, não deixa, no entanto, de tecer comentários favoráveis sobre muitas outras que pôde observar na companhia do "professeur Fonseca", então "Lente de Pintura Historica da Academia de Bellas Artes de Lisboa”422 e um dos avaliadores daquele conjunto.

Ora, mesmo se as atribuições apresentadas pelo académico António Manuel da Fonseca e pelo pintor restaurador italiano, Luís Tirinnazi, no inventário e avaliação, para efeitos de leilão ${ }^{423}$, impressas na "Relação dos Quadros pertencentes à Herança da Imperatriz Rainha a Senhora D. Carlota Joaquina de Bourbon [...]", revelam, como era corrente na altura, falta de rigor científico, sendo mencionados, quase sempre, nomes de grandes mestres da pintura e não de seus epígonos, ou mesmo o facto de algumas obras serem cópias assumidas, não deixa de ser verdade que, naquele espólio, se encontravam verdadeiras preciosidades que hoje engrandecem as colecções dos Museus Nacionais.

\section{Coleccionador, "connoisseur", "curieux", "amateur"}

O facto de sabermos que uma parte das obras leiloadas na Bemposta, corresponde à "Tercera Division $^{\prime \prime 24}$, isto é, foram herdadas por D. Carlota Joaquina, pouco tempo antes da sua morte, poderia fazer-nos questionar o papel que aquela soberana sustentara, no campo do coleccionismo de arte. No entanto, é igualmente certo que, antes da chegada desse lote, a então Princesa do Brasil, já dispunha de um património que se destacava pela sua excelência, como julgamos ter provado com diversos exemplos apresentados, ao longo do trabalho, nomeadamente na referência aos diversos inventários da sua Casa do Ramalhão, prévios e durante a estadia no Brasil. Património de diversas proveniências, parte do qual hoje se inclui nas colecções dos Palácios e Museus Nacionais. O confronto de diversa documentação, nomeadamente a comparação da lista das pinturas herdadas e a das constantes no catálogo daquele leilão, permite-nos concluir que faltam, neste, algumas obras mencionadas naquele manuscrito, e no catálogo existem outras que não constam da herança paterna.

\footnotetext{
${ }^{421}$ Raczynski, obra citada, 1846, p. 280. BA 149-XV-88.

${ }^{422}$ António Manuel da Fonseca (1796-1890), nomeado em 1836, professor de Pintura Histórica da Academia Real de Belas Artes.

${ }^{423}$ Relação dos Quadros pertencentes à Herança da Imperatriz Rainha a Senhora D. Carlota Joaquina de Bourbon, assinada por Francisco José Caldas Aulete, Solicitador da Caza Real, impressa em Lisboa, 1844. ${ }^{424}$ BA 54-X-33 (7).
} 
A resposta à questão se D. Carlota Joaquina seria uma coleccionadora, socorrendo-nos das reflexões do historiador do coleccionismo K. Pomian, podemos afirmar que o foi. Diz o autor que "[...] avoir des tableaux et être un collectionneur de tableaux sont des choses bien différentes. Dans le premier cas, on remplit les murs pour qu'ils ne soient pas vides, et les tableaux jouent essentiellement un rôle décoratif. Dans le second, il arrive qu'on édifie les murs pour y disposer les tableaux dont le nombre et le choix montrent que leur rôle est non pas tant de décorer que d'attirer le regard vers la peinture elle-même et susciter des interrogations dont elle serait l'objet". Não sendo, no entanto, a fronteira entre uma e outra definição de uma limpidez perfeita já que, reportando-nos àquela época, "un tableau ne saurait jouer de rôle purement décoratif car il représente toujours quelque chose, tandis que, d'autre part, tout tableau joue un rôle décoratif dès qu'il est placé sur un mur. [...]"425.

Seguindo aquele autor, podemos considerar que D. Carlota Joaquina, na sua Casa-Quinta do Ramalhão, se preocupou com a adaptação de um espaço para a apresentação da sua própria colecção de pintura, isto é, a denominada "Caza da Pintura no 9", mencionada na relação datada de $1807^{426}$, onde se concentravam as colecções de pintura, bem como os objectos de história natural, que constituíam o "Muzeu", termo que surge no inventário de $1829^{427}$, demonstrando a importância que o conhecimento, a cultura e a arte assumiam no seu quotidiano, deste modo afirmando uma sensibilidade artística e um gosto culto e informado.

O perfil de coleccionadora da Imperatriz Rainha, corresponderia, do nosso ponto de vista, não ao de "connoisseur", enquanto alguém que reúne, mediante um plano estruturado, um conjunto de obras de arte, assumindo a sua actividade um carácter científico - "understood in its eighteenth-century sense as a branch of knowledge based on methodical and rational principles of investigation" ${ }^{428}$, mas sim, ao de um "amateur", definido por Kristel Smentek, como aquele cuja ligação com a arte "was one of taste and social position" 429 . A relação com as obras de arte e o meio artístico seria, assim, fruto de uma aprendizagem informal, em resultado de uma vivência em ambientes de cortes ilustradas, nas quais os monarcas relevavam o papel de mecenas, de patronos dos artistas e de promotores de academias e instituições nucleares para o ensino artístico.

425 POMIAN, Krzysztof, Collectionneurs, amateurs et curieux. Paris, Venise: XVIo - XVIIIo siècle, Bibliothèques des Histoires, Éditions Gallimard, 2001, pp. 126-127.

${ }^{426}$ ANTT, Casa das Rainhas, Livro 234 (1807).

427 ANTT, Casa Real, Cx. 3703, n.o 387.

${ }^{428}$ SMENTEK, Kristel, 2014, pp. 2-3.

${ }^{429}$ Idem, ibidem, 2014, p. 3. 
As colecções de D. Carlota Joaquina corresponderiam a um espírito de amador - "amateur", com o duplo sentido que comporta a palavra, enquanto testemunho de um desejo de arte, o Kunstwollen de que falava Alois Riegl (1858-1905), o amor pela arte, e de um desejo de conhecimento, que the conferia um perfil de mulher ilustrada.

Verificamos que para a formação inicial de D. Carlota Joaquina teria concorrido a precoce inserção da então Infanta de Espanha, tanto na corte de Espanha, como na de Portugal, "num mundo de pessoas, de práticas e de objectos cultivados" ${ }^{430}$, de que falava Bourdieu, potenciado e complementado por mestres encarregues da sua educação, configurando um exemplo de formação fora das instâncias académicas, vedadas então ao género feminino, mas consumada no seio da família e da corte, com mestres adequados à sua alta hierarquia ${ }^{431}$, que Ihe teria conferido um à-vontade no campo cultural que demonstrou ao longo da vida.

Socorremo-nos, de novo, das palavras de Cyrillo Wolkmar Machado (1748-1823), testemunha coeva, para confirmar a "real munificência" e "protecção" dos monarcas ao universo artístico, não esquecendo de nomear a Rainha, destacando a familiaridade de D. Carlota Joaquina com o universo cultural e artístico, ignoradas quase até à actualidade. E o eco que julgamos tiveram em Paulo Varela Gomes (1952-2016) quando defende que, do ponto de vista artístico, o período que decorreu entre 1780 e a 1. a Invasão napoleónica (tempo que corresponde ao reinado de D. Maria I e Regência de D. João, após 1792 e até 1807), "teria constituído um dos (períodos) mais ricos e activos da história artística de Portugal correspondendo, aliás, a um ciclo de grande prosperidade económica" e que, "especialmente do ponto de vista da encomenda de estado (mas também da privada) de quadros e painéis de pintura de história, sustenta favoravelmente a comparação com o ocorrido na própria Grã-Bretanha [...] onde o estado e os particulares não manifestavam interesse senão pelo retrato ou pela pintura dos "Grandes Mestres" ${ }^{432}$. As campanhas de Mafra e da Ajuda são, aliás, consideradas pelo autor como "caso único na Europa neoclássica de então", comparando a situação portuguesa, na qual D. Rodrigo de Sousa Coutinho, 1.o Conde de Linhares (1745-1812) encarregara a Marquesa de Alorna, em 1802, de elaborar o plano das pinturas da Ajuda - "podendo o gosto oficial ser ainda o do neoclassicismo como ele fora entendido em França e na Grã-Bretanha

\footnotetext{
${ }^{430}$ BOURDIEU, Pierre, La Distinction, critique sociale du jugement, Les Éditions de Minuit, 1979, p. 81.

${ }^{431}$ Apud. Vásquez, Raquel Bello, Mulheres do Século XVIII, A Condessa do Vimieiro, Ela por Ela, Setembro 2006.

${ }^{432}$ GOMES, Paulo Varela, "Correntes do Neoclassicismo europeu na pintura portuguesa do século XVIII", in Portugal e Espanha entre a Europa e Além Mar, IV Simpósio Luso-Espanhol de História da Arte, Instituto de História da Arte, Universidade de Coimbra, Coimbra, 1988, p. 480.
} 
nos anos 60 e 70 do século" - com a "do Reino Unido, no qual o estado abandonava o seu papel de patrono da pintura de história; ou em França, onde o Imperador Napoleão encomendava a David, não a história do país, mas a sua própria"433.

As palavras de Varela Gomes que parecem ter suporte nas afirmações de Cyrilo, aquele que o autor considerou ser o primeiro historiador da arte português ${ }^{434}$, traçam um retrato menos sombrio do patrocínio e mecenato cultural, quer régio, quer das elites, em Portugal, no final do Antigo Regime. Com o apurado sentido crítico que a sua vida e obra testemunharam, Varela Gomes abre novas perspectivas de estudo, também neste campo específico dos consumos artísticos e do coleccionismo artístico em Portugal, no final do Antigo Regime. Julgamos poder afirmar que, de algum modo, contrariou a visão mais depreciativa deixada por José-Augusto França, cuja avaliação sobre aquele período segue de perto as imagens deixadas por Oliveira Martins (1845-1894), que com a sua genial veia literária, e apesar do seu "confesso posicionamento antiliberal”335, foi um autor que muito contribuiu para o desenho grotesco dos últimos monarcas absolutos, pese embora as suas simpatias por D. Miguel (1802-1866); ou a escrita de Raul Brandão, entre outros, no recorte de uma corte culturalmente pobre e atrasada, apenas escapando do juízo crítico de José-Augusto França os poucos que, por força de cargos diplomáticos, conseguiam escapar a um destino de obscuridade.

Aquelas imagens depreciativas sobre as elites de Antigo Regime encontram, igualmente, suporte no relato de alguns escritores viajantes, à excepção de William Beckford que na realidade fôra dos poucos a ter acesso às casas da primeira nobreza de corte portuguesa, de entre as quais as dos Marqueses de Marialva e Angeja, do Conde de Penalva, entre outras, tanto em Lisboa, como em Sintra, e que, por isso, os seus relatos continuam de uma importância capital quando se trata de analizar a sociedade portuguesa daquele período.

Castelo Branco Chaves refere a propósito da visão desprimorosa que J. B. F.Carrère apresenta sobre as Artes em Portugal, no seu livro Panorama de Lisboa no ano de 1796, que a mesma se devia provavelmente à impossibilidade do autor "de visitar os palácios e conventos onde existiam tesouros artísticos, galerias de pintura e bom mobiliário", que o teria levado a deduzir "que não havia em Portugal nem mais nem melhor que aquilo que the esteve ao alcance do

\footnotetext{
433 Idem, ibidem.

${ }^{434}$ GOMES, Paulo Varela, A confissão de Cyrillo. Estudos de História da Arte e da Arquitectura, Lisboa Hiena, 1992, p. 15.

${ }^{435}$ CATROGA, Fernando, História da História em Portugal Sec.s XIX-XX. Círculo de Leitores, 1996, p. 151.
} 
conhecimento no meio pobre, restrito, em que foi forçado a viver ${ }^{\prime \prime 436}$. A perda de rendimentos das Casas da primeira nobreza de corte ${ }^{437}$, no final do Antigo Regime, determinara o seu empobrecimento e crescente endividamento, durante a Época Contemporânea, levando a hastas públicas muito do património de que dispunham. Mas tal não significa que o coleccionismo artístico não tivesse existido, como comprovam diversos inventários relativos a partilhas, existentes nos arquivos nacionais, apesar da situação "periférica" da corte portuguesa, relativamente aos principais centros de produção artística e mercado de arte, europeus. A hegemonia da corte no que respeita às encomendas artísticas, dificultava o acesso aos principais artistas que se encontravam alocados aos empreendimentos régios.

${ }^{436}$ CARRÈRRE, J. B. F., Panorama de Lisboa no ano de 1796, Série Portugal e os Estrangeiros, Biblioteca Nacional, 1989, p. 28. Diz Castelo Branco Chaves, organizador da colecção, que esta obra pertence à categoria dos livros que "têm de ser lidos com grandes reservas e muito frequentemente emendados", pp. 32 e 189, notas ao referido texto.

437 Sobre esta temática v. obra fundamental de MONTEIRO, Nuno Gonçalo Freitas, O Crepúsculo dos Grandes. A casa e o património da aristocracia em Portugal (1750-1832), Imprensa Nacional-Casa da Moeda, Lisboa, 2003. 


\section{XII - Conclusões e Notas Finais}

Apesar dos inúmeros testemunhos iconográficos, epigráficos, manuscritos e impressos, só muito raramente no campo da História da Arte é mencionado o papel tutelar dos últimos monarcas do regime absoluto português, sobre o legado cultural e patrimonial de que as actuais instituições museológicas são tributárias, assim como o seu contributo para a criação de instituições culturais, em ambos os países envolvidos na sua acção. A avareza de julgamento por parte da historiografia oitocentista e novecentista, relativamente a estas matérias é, no entanto, contrariada por muita documentação coeva, confirmando as palavras de um dos mais importantes historiadores da arte portugueses do século XX, Paulo Varela Gomes (1952-2016), o que demonstra o quanto ainda estes temas carecem de estudo.

No caso da Rainha D. Carlota Joaquina, a anti-heroína para uma dada corrente da historiografia ${ }^{438}$, a qual realçou essencialmente os traços comportamentais negativos, decorrentes da ingerência nos assuntos políticos e de Estado, e polarizou a leitura sobre o seu significado histórico, teve como consequência a ocultação de dimensões relacionadas com os aspectos privados da sua actividade, enquanto coleccionadora de arte, leitora atenta, activa protectora dos artistas e agentes culturais. São muitas as faces possíveis de abordar aquela personalidade, o que levou Sara Marques Pereira a intitular a sua biografia sobre D. Carlota Joaquina - "Espelhos de Clio: actuação política e figurações historiográficas"439, na qual desenvolveu o relevante trabalho de reconhecimento da acção da monarca, à luz de um rigoroso levantamento documental, conjugado com uma pluralidade de fontes e textos interpretativos, tanto do sector tradicionalista, como os de uma historiografia de pendor liberal, com os quais quis situar a acção da soberana, colocando a par da "lenda negra", a "lenda dourada".

Importa, pois, prosseguir no confronto entre as imagens legadas pela historiografia, maioritariamente feita a partir do ponto de vista dos liberais vencedores, e a leitura da

\footnotetext{
438 Para A. H. Oliveira Marques a conflitualidade permanente entre o casal real, levou-o a afirmar que "pior que tudo, porém, foram os projectos políticos diferentes que cada qual acarinhou, pondo em perigo interesses nacionais e levando a conspirações, assassinatos, Golpes de Estado e até guerras civis", considerando mesmo a união de D. João com Dona Carlota Joaquina, na senda do que escreveu Oliveira Lima, como um acontecimento nefasto na vida do rei "e um facto deplorável na história de Portugal do tempo", in D. João VI e o seu tempo, catálogo da exposição, Comissão Nacional para a Comemoração dos Descobrimentos Portugueses, Lisboa, 1999, p. 31.

439 PEREIRA, Sara Marques, D. Carlota Joaquina e os Espelhos de Clio: actuação política e figurações historiográficas, Livros Horizonte, 1999.
} 
documentação coeva e dos testemunhos materiais herdados, relativos aos diferentes elementos das elites de Antigo Regime e sobre o contributo que prestaram para a difusão da "Ilustração", bem como na criação de instituições culturais relevantes. Como escreve Ignacio Gómez de Llaño, a propósito das consequências das escavações arqueológicas patrocinadas por Carlos III (1716-1788), então Rei das Duas Sicílias, em Herculano e Pompeia, uma das ironias da História, "dos regímenes políticos empeñados en acabar com lo antíguo y, en particular, com la disnastia borbónica, como la Revolución Francesa y el Imperio napoleónico, van a ser los herederos estéticos de la investigación arqueológica patrocinada por un monarca" ${ }^{\prime 40}$ dessa dinastia, representante destacado do absolutismo ilustrado e de Antigo Regime, prosseguindo a ideia de Alexis de Tocqueville (1805-1859) que "Des liens invisibles mais presque tout-puissants attachent les idées d'un siécle à celles du siècle qui l'a précédé, les goûts des fils aux penchants des pères. [...]. On ne saurait donc parler d'une nation à une époque donnée, sans dire ce qu'elle a été un demi-siècle auparavant" ${ }^{\prime 441}$.

Quisemos, com este trabalho, dar um contributo para iluminar o papel de D. Carlota Joaquina, a Princesa-artista, na corte joanina, a cuja lenda "negra" se deve atribuir, essencialmente, à defesa intransigente que fez da sua mundivisão no espaço público, facto que a intelectualidade oitocentista condenará, pois como afirmava J. Michelet (1798-1874), intelectual francês que tanta influência exerceu no pensamento do seu tempo, e nas ideias de Alexandre Herculano (1810-1877), ou de Oliveira Martins (1845-1894), o lugar da mulher seria a secundar o seu marido e não na afirmação de identidade própria. A frase daquele "La femme ne vit pas sans I'homme" sintetiza, de um modo lapidar, não só o pensamento do maior historiador francês do período romântico mas, igualmente, a visão oitocentista sobre o lugar da mulher na sociedade, consignada "à l'espace privé et au decoratif", ao mesmo tempo que aos homens era destinado o espaço público, a dominação política e económica ${ }^{442}$.

O papel atribuído às mulheres pela intelectualidade oitocentista, confinada ao lar e na dependência do marido, fazia de D. Carlota Joaquina um antimodelo pois, se a soberana prezou as qualidades da vida privada, da leitura, da reflexão e da instrução dos filhos, não deixou, no entanto, de fazer uma afirmação enérgica da sua mundivisão, como ficou patente naquele que ficou denominado como "o processo da Rainha", por se ter recusado a jurar as

\footnotetext{
440 LLAÑO, Ignacio Gómez de, El Reino de las Luces. Carlos III entre el Viejo y el Nuevo Mundo, Alianza editorial, Madrid, 2015, p. 57.

${ }^{441}$ TOCQUEVILLE, Alexis, L'Ancien Régime et la Revolution, GF Flammarion, Paris 1988, p. 46.

${ }^{442}$ LIPOVETSKY, Gilles; ROUX, Elyette, Le Luxe Éternel, de l'âge du sacré au temps des marques, Le débat, Gallimard, 2003, pp. 78-79.
} 
Bases da Constituição de 1822, que seu marido outorgara. A defesa dos seus pontos de vista foi feita com tal firmeza que polarizou o debate público, galvanizando e dividindo opiniões, quase até à actualidade, contaminando toda a análise histórica sobre o seu legado.

Como afirmou F. Catroga, "na passagem da sociedade do Ancien Regime para a modernidade" [...] "as condições da escrita da história sofreram profundas transformações: a revolução liberal introduziu uma consciência de ruptura, de descontinuidade", assumindo, a partir de então, os historiadores, a "função social de ideólogos da consciência nacional", participando na construção de narrativas, compondo uma historiografia que se alicerçou sobre memórias e esquecimentos, exaltações e recalcamentos ${ }^{443}$.

Em síntese. Foram, pois, as circunstâncias especiais da vida da infanta de Espanha, princesa do Brasil, Rainha e Imperatriz do Reino Unido de Portugal e do Brasil, foi a sua educação religiosa e os ambientes de corte onde foi educada que transmitiram à vida de D. Carlota Joaquina, num tempo cheio de contradições, uma feição característica e singular pois, se politicamente conservadora, a sua mundivisão era compartilhada, não só por monarcas e elites aristocráticas ditas "iluminadas", como por muitos intelectuais e pensadores que abriram novas perspectivas de pensamento, naquele início de século XI. O caso de F. R. de Chateaubriand (1768-1848) é aliás paradigmático do estado de espírito e do posicionamento de uma elite intelectual, que levou Arnold Hauser, na sua obra História Social da Arte, a afirmar que naquele, como mais nenhum outro tempo, foi possível conjugar uma disposição política conservadora com uma apetência artística inovadora, sendo aquele autor apontado como "o mais notável o exemplo dessa dupla condição pois, se foi inegavelmente inovador em termos de criação literária foi, em simultâneo, profundamente conservador do ponto de vista político", logrando "combinar sua visão progressista da arte com o seu conservadorismo político, seu monarquismo e clericalismo, seu entusiasmo pelo trono e o altar"444. Em França, terra da Revolução, os românticos declararam-se legitimistas e clericalistas inicialmente, ao passo que a tradição clássica na literatura e na arte, está representada principalmente pelos liberais ${ }^{445}$, o que não deixa de representar, do ponto de vista estético, uma postura conservadora. Ou seja, um anacronismo, por adoptar como modernas, formas estéticas influenciadas pela Antiguidade Clássica.

\footnotetext{
${ }^{443}$ Catroga, Fernando, "O Historiador dentro da Cidade: História e Política”, in Lisbon Historical Studies, no prelo, p. 135.

${ }^{444}$ HAUSER, Arnold, História Social da Arte, 2003, Martins Fontes, S. Paulo, pp. 687-688.

445 Idem, ibidem, p. 685.
} 
Os dilemas de D. Carlota Joaquina espelham, pois, um tempo de agudas tensões e confrontos entre distintas mundivisões ideológicas, compagináveis com a atitude que, depois da Revolução Francesa, foi adoptada por uma camada intelectual, na oposição ao racionalismo do século XVIII, pelas responsabilidades que foram Ihe imputadas no desabamento da sociedade de Antigo Regime. Como explicita Jochen Schlobach "Il est evident que les sympathies des souverains même les plus ouverts aux Lumières françaises cessaient là où leur propre souverainité se trouvait menacée $\mathrm{e}^{\prime 46}$.

Arreigada às suas conviç̧ões, como genuína Bourbon de Espanha, neta de Carlos III (17161788), rei que prosseguiu uma política de despotismo iluminado, foi pouco acessível a qualquer manifestação de perda das prerrogativas régias. Apesar de leitora da filosofia contemporânea, nos quais se incluíam J. J. Rousseau (1712-1778) e Condorcet (1743-1794), não se deixou embeber pelas doutrinas constitucionais e liberais que vingariam no século XIX.

Inabalável nas suas crenças, tornou-se hostil aos movimentos políticos laicizantes, que despontavam naquele início de século, por neles se acentuarem tendências que rejeitava, conservando-se, até à sua morte, uma defensora dos valores nos quais fora educada, da união do trono com o altar, do poder secular unido ao poder espiritual.

No entanto, o seu legado cultural que permanece quer na Biblioteca da Ajuda, quer em Museus e Palácios nacionais, está aí para afirmar uma presença culta e instruída, longe da imagem obscurantista que alguma historiografia lhe quis colar.

Chegou, pois, o momento de voltar a auscultar as fontes contemporâneas, as "vozes" que refere Javier Fernández Sebastián ${ }^{447}$, à luz de novas preocupações que emergem relativas à história das mulheres, ou dos grupos "vencidos" ${ }^{48}$ que, mais recentemente, têm constituído um corpo de estudo da História.

\footnotetext{
${ }^{446}$ SCHLOBACH, Jochen, "L'image des Princes Éclairés au 18.e Siècles”, in Portugal no Século XVIII de D. João V à Revolução Francesa, Sociedade Portuguesa de Estudos do Século XVIII, Universitária Editora, 1991, p. 45.

447 SEBASTIÁN, Javier Fernández, "Algumas notas sobre história conceptual e sobre a sua aplicação ao espaço atlântico ibero-americano", Ler História, 2008, p. 5.

448 WACHTEL, Nathan, "La vision des vaincus: la conquête espagnole dans le folklore indigène", in Annales. Économie, Sociétés, Civilisations. 22.e année, n.o 3, 1967, p. 554.
} 


\section{Bibliografia}

\section{Impressos}

ARAÚJO, Agostinho, "Experiência da Natureza e Sensibilidade Pré-Romântica em Portugal. Temas de Pintura e seu consumo (1780-1825", Dissertação de Doutoramento em História da Arte, Fac. Letras do Porto, 1991. http://hdl.handle.net/10216/13668. Janeiro 2019 AZEVEDO, Francisca L. Nogueira de, Carlota Joaquina na Corte do Brasil, Civilização Brasileira, Rio de Janeiro, 2003; Carlota Joaquina Cartas Inéditas, Rio de Janeiro, Casa da Palavra, 2007; BARRETO, D. José Trazimundo Mascarenhas, Memórias do Marquês de Fronteira e d'Alorna, ditadas por êle próprio em 1861, revistas e coordenadas por Ernesto Campos de Andrada, Parte Primeira e Segunda (1802 a 1824), Coimbra, Imprensa da Universidade, 1928 BASTOS, Celina; CAETANO, Joaquim Oliveira, Luca Giordano. Êxtase de São Francisco, MNAA, Março de 2014; BASTOS, Celina, "Os interiores régios de D. Maria I a D. Maria II», in SOUSA, Gonçalo Vasconcelos e (dir.), Matrizes da Investigação em Artes Decorativas. V, Porto, Universidade Católica do Porto/ CITAR, 2013; BASTOS, Celina, FRANCO, Anísio, «Para Memória Futura: Interiores Autênticos em Portugal», in MALTA, Marize, MENDONÇA, Isabel M. G. (org.), Casas senhoriais Rio-Lisboa e seus interiores, Estudos Luso-brasileiros em Arte, Memória e Património, Lisboa/ Rio de Janeiro, Universidade Federal do Rio de Janeiro/ Universidade Nova de Lisboa/ Fundação Ricardo do Espírito Santo Silva, 2013-2014

BECKFORD, William, Diário de William Beckford em Portugal e Espanha", introdução e notas de Boyd Alexander, traduzido por João Gaspar Simões, Empresa Nacional de Publicidade, 1957; A Côrte da Rainha D. Maria I, Livraria Editora Tavares Cardoso § Irmão, Lisboa, 1901 BLANCO, Francisco Cordeiro, "Uma Carta Inédita de Vieira Portuense", in Boletim do Museu Nacional de Arte Antiga, Vol. I, n.o 3, Lisboa, 1948

BONIFÁCIO, Maria de Fátima, Memórias do Duque de Palmela, ed. D. Quixote, 2011 BOURDIEU, Pierre, La Distinction, critique sociale du jugement, Les Éditions de Minuit, 1979 BOTTINEAU, Yves, L'Art de Cour dans I'Espagne des lumières, 1746-1808, Paris 1986 BRIGOLA, João Carlos, Os viajantes e o "livro dos museus". As colecções portuguesas através do olhar dos viajantes estrangeiros (1700-1900). Dafne Editora, Porto 2010

CARITA, Helder, A Casa Senhorial em Portugal. Modelos, Tipologias, Programas Interiores e Equipamento, Leya, 2015

CARRÈRRE, J. B. F., Panorama de Lisboa no ano de 1796, Série Portugal e os Estrangeiros, Biblioteca Nacional, 1989 
CARVALHO, Ayres, Os Três Arquitectos da Ajuda. Do "Rocaille" ao Neoclássico. Academia Nacional de Belas-Artes, Lisboa, 1979; A Galeria Nacional de Pintura da Academia Real das Belas-Artes (1868) - o catálogo do Marquês de Sousa Holstein, Lisboa, 1982

CARVALHO, José Alberto Seabra, "Uma cronologia", in Sequeira 1768-1837. Um português na mudança dos tempos, Museu Nacional de Arte Antiga, 1997

CATROGA, Fernando, História da História em Portugal Sec.s XIX-XX. Círculo de Leitores, 1996; "O Historiador dentro da Cidade: História e Política", in Lisbon Historical Studies, no prelo, CEBALLOS, Alfonso Rodriguez G. de, "Goya y Carlo IV", in Carlos IV y el Arte de su reinado, Actas de Jornadas de Arte e Iconografia, Fundación Universitaria Española, Madrid, 2011 CHAUNU, Pierre, A Civilização da Europa das Luzes, Volume II, Editorial Estampa, 1995 CHECA, Carmen García-Frías, "Nuevas aportaciones al estúdio de la colección pictórica de Carlos IV en el exilio", in Actas de las Jornadas de Arte e Iconografia Carlos IV y el arte de su reinado, Fundación Universitaria Española, Outubro 2011

Francisco Costa, Beckford em Sintra no Verão de 1787 - História da Quinta e Palácio do Ramalhão, Câmara Municipal de Sintra, 1982

COSTA, Luiz Xavier, O Ensino das Belas-Artes nas Obras do Real Palácio da Ajuda (1802 a 1833), Academia Nacional de Belas Artes, Lisboa, 1936

CUESTA, Miguel Hermoso, “A propósito de un lienzo de Lucas Jordán en el Museu Nacional de Arte Antiga de Lisboa", Anales de Historia del Arte, 2010

DELAFORCE, Angela, Art and Patronage in Eighteenth-Century Portugal, Cambridge University Press, 2002

DEGORTES, Michela; RAGGI, Giuseppina, "Giuseppe Trono, Pintor de Retratos na Corte portuguesa (1785-1810), in Artis, Revista Instituto História da Arte, Fac. Letras, Universidade de Lisboa, N.o 5, 2017, pp. 209-221; A Pintura de Giuseppe Trono na Capela do Paço da Bemposta, Edições Colibri, 2019

DIDI-HUBERMANN, Georges, Devant le Temps, Les Éditions de Minuit, Paris, 2002

FARIA, Miguel Figueira de, A Casa Literária do Arco do Cego: Exemplo Singular na História da Edição Ilustrada em Portugal. Apontamentos para uma biografia. Repositório Camões, 2001. http://hdl.handle.net/11144/2479. Consulta online, Janeiro de 2019; A Imagem Impressa: produção, comércio e consumo de gravura no final do Antigo Regime, Tese de Doutoramento, Repositório Camões, UAL, 2005, http://hdl.handle.net/11144/2490. Consulta online, 3 de Março de 2019.

FRANÇA, José-Augusto, A Arte em Portugal no século XIX, Livraria Bertrand, Lisboa, 1966

FRANCO, Carlos, Casas das Elites de Lisboa. Objetos, interiores e vivências 1750-1830. Scribe, 2015 
GOMES, Paulo Varela, "Correntes do Neoclacissismo Europeu na Pintura Portuguesa do século XVIII", Sep. do IV Simpósio Luso-Espanhol de História da Arte. Portugal e Espanha entre a Europa e Além-Mar, Instituto de História da Arte, Fac. Letras, Universidade Coimbra, 1988; A confissão de Cyrillo. Estudos de História da Arte e da Arquitectura, Lisboa Hiena, 1992; Reviewed Work(s): "Art and Patronage in the Eighteenth-Century Portugal by Angela Delaforce", in The Journal of the Society of Architectural Historians, vol. 62, n.o 1, Mar. 2003 GONZALEZ-PALACIOS, Alvar, Las Colecciones Reales Espanolas de Mosaicos y Piedras Duras, Madrid, Museu Nacional del Prado, 2001

HASKELL, Francis, El museo efímero, Editorial Crítica, Barcelona, 2002

HAUSER, Arnold, História Social da Arte, Martins Fontes, S. Paulo, 2003

LIMA, Henrique de Campos Ferreira, Joaquim Rafael Pintor e Escultor Portuense, Imprensa da Universidade, Coimbra, 1923; Princesas Artistas (As Filhas de El-Rei D. José), Subsídios para a História da Arte Portuguesa, Imprensa da Universidade, Coimbra, 1925

LIMA, Oliveira, D. João VI 1808-1821, Ed. ACD Editores, 200 Anos Portugal Brasil, s/data.

LLAÑO, Ignacio Gómez de, El Reino de las Luces. Carlos III entre el Viejo y el Nuevo Mundo, Alianza editorial, Madrid, 2015

LIPOVETSKY, Gilles; ROUX, Elyette, Le Luxe Éternel, de l'âge du sacré au temps des marques, Le débat, Gallimard, 2003

MACHADO, Cyrillo Volkmar, Collecção de memórias relativas as vidas dos pintores, $e$ escultores, architectos, e gravadores portugueses e dos estrangeiros que estiveram em Portugal [...], Lisboa, 1823

MADUREIRA, Nuno Luís, Cidade: Espaço e Quotidiano. Lisboa 1740-1830, Livros Horizonte, Lisboa, 1992

MALKIEL-JIRMOUNSKY, Myron, Pintura à Sombra dos Mosteiros, Edições Atica, Lisboa, 1957

Marquês de Sousa Holstein, Catalogo Provisorio da Galeria Nacional de Pintura existente na Academia Real das Bellas Artes de Lisboa, 2. a edição, Lisboa, 1872

MARTINS, Oliveira, Portugal Contemporâneo, Vol. I, Lello e Irmão Editores, Porto, 1981

MONTEIRO, Nuno Gonçalo Freitas, O Crepúsculo dos Grandes. A casa e o património da aristocracia em Portugal (1750-1832), Imprensa Nacional-Casa da Moeda, Lisboa, 2003

PAMPLONA, Fernando, Dicionário de Pintores e escultores Portugueses ou que trabalharam em Portugal, I Volume, Lisboa, 1954

PEREIRA, Ângelo, As Senhoras Infantas Filhas D'El Rei D. João VI, Editorial Labor, Lisboa, 1938 PEREIRA, José Fernandes, "Francisco de Assis Rodrigues ou o mal-estar de um clássico entre românticos", Arte teoria, Faculdade de Belas Artes, Lisboa, 2000 
PEREIRA, Sara Marques, D. Carlota Joaquina e os Espelhos de Clio: actuação política e figurações historiográficas, Livros Horizonte, 1999; D. Carlota Joaquina Rainha de Portugal, Livros Horizonte, 2. ed edição, 2008.

PIMENTEL, Alberto, A última Côrte do Absolutismo em Portugal, Lisboa, Livraria Ferin, 1893

PIRES, António Caldeira, História do Palácio de Queluz, Vol. II, Coimbra, Imprensa da Universidade, 1926

POMIAN, Krzysztof, «Médailles/coquilles = érudition/ philosophie», Collectionneurs, amateurs et curieux. Paris, Venice: XVIe - XVIIle siècle, Éditions Galimard, Millau, 2001

PRESAS, José, Memórias Secretas de la Princesa del Brasil, actual Reina viúda de Portugal, La Señora Doña Carlota Joaquina de Bourbon, Burdeos, 1830

RACZYNSKI, Le Comte, Les Arts en Portugal, Lettres Adresssés A la Société Artistique et Scientifique de Berlin et accompagnées de documens, Paris, 1846 RODRIGUES, Paulo Simões, “O Conde Athanasius Raczynski e a Historiografia da Arte em Portugal", Revista de História da Arte, n. 8, 2011

RUBIO, J. M., La Infanta Carlota Joaquina y la Politica de España en America (1808-1812), Biblioteca de Historia Hispano-Americana, Madrid, 1920

SÁ, J. Ribeiro de, "Um Brado a Favor da Gloria Nacional e das Bellas-Artes", O Panorama, Vol. 1, 3. , Série 2.a , Lisboa, Jan/Dez de 1844; "Almoeda no Palácio da Bemposta", na Revista Universal Lisbonense, Imprensa da Gazeta dos Tribunais, Tomo VII, 1847-1848, Lisboa SANTOS, Paula Mesquita, "A Colecção de D. Carlota de Bourbon, oriunda do Ramalhão, em Sintra [...]", in Vária Escrita, n.ㅇ 2, Sintra 1995

SARAIVA, José da Cunha, "Os Quadros do Ramalhão que foram para a Academia de Belas Artes", Feira da Ladra, vol. 7, 1936-1937

SARDINHA, António, Ao Princípio era o Verbo, Ensaios e Estudos, Livraria Portugália, Lisboa, 1924

SCHLOBACH, Jochen, "L'image des Princes Éclairés au 18.e Siècles", in Portugal no Século XVIII de D. João $V$ à Revolução Francesa, Sociedade Portuguesa de Estudos do Século XVIII, Universitária Editora, 1991

SEBASTIÁN, Javier Fernández, "Algumas notas sobre história conceptual e sobre a sua aplicação ao espaço atlântico ibero-americano", Ler História, 2008

SMENTEK, Kristel Mariette and the Science of the Connoisseur in Eighteenth-Century Europe, Studies in Art Historiography, Ashgate, 2014

SOARES, Clara Moura, "Os Recheios do Paço do Ramalhão (Sintra, Portugal): A Herança e o Gosto Artístico da rainha D. Carlota Joaquina de Bourbon", comunicação apresentada no VIII 
Seminário do Museu D. João VI, IV Colóquio Internacional Colecções de Arte em Portugal e Brasil Nos Séculos XIX e XX. Arte e seus Lugares: Coleções em Espaços Reais, 2017

SOARES, Ernesto, in História da Gravura Artística em Portugal. Os artistas e as suas obras, Tomo I, Lisboa, 1940.

SOBRAL, Luís de Moura, A Pintura Maneirista em Portugal, Arte no tempo de Camões, coordenação científica Vitor Serrão, Comissão Nacional para a Comemoração dos Descobrimentos Portugueses, Lisboa, 1995

TEIXEIRA, José Monterroso, José da Costa e Silva (1747-1819) e a receção do neoclassicismo em Portugal: a clivagem de discurso e a prática arquitetónica, tese de doutoramento. Repositório Institucional Camões, Universidade Autónoma de Lisboa, 2013. http://hdl.handle.net/11144/305. Consulta Janeiro 2019

TOCQUEVILLE, Alexis, L'Ancien Régime et la Revolution, GF Flammarion, Paris, 1988

WACHTEL, Nathan, "La vision des vaincus: la conquête espagnole dans le folklore indigène", in Annales. Économie, Sociétés, Civilisations. 22.e année, n.ㅇ 3, 1967

VÁZQUEZ, Raquel Bello, A Condessa do Vimieiro, Mulheres do Século XVIII, Ela por Ela, FCT, 2006

VIANA, António; LYRA, Maria de Lourdes Viana, Carlota Joaquina Leopoldina de Habsburgo, Rainhas de Portugal no Novo Mundo, Colecção Rainhas de Portugal, Temas e Debates, Lisboa, 2019

XAVIER, Hugo, Galeria de Pintura no Real Paço da Ajuda, INCM, 2013; "O Marquês de Sousa Holstein e a formação da Galeria Nacional de Pintura da Academia de Belas Artes de Lisboa", Tese de Doutoramento em História da Arte, FCSH: DHA, Lisboa, 2015

\section{Periódicos}

A Carta, n.o 70, 13 de Dezembro de 1847

O Panorama, vol. 3.o, Série 2.a , Lisboa, Jan./Dez. 1844

O Panorama, n. 109, 27 de Janeiro de 1844

Revista Universal Lisbonense, Imprensa da Gazeta dos Tribunais, Tomo VII, 1847-1848, Lisboa

Boletim da Biblioteca da Universidade de Coimbra, Vol. XXVI, Coimbra, 1964

\section{Catálogos}

A Perspectiva das Coisas. A natureza-Morta na Europa, Volume I. Catálogo da exposição, Fundação Calouste Gulbenkian, Lisboa, Fevereiro de 2010.

D. João VI e o seu tempo, catálogo da exposição, Comissão Nacional para a Comemoração dos Descobrimentos Portugueses, Lisboa, 1999 
"Catalogo de livros defesos neste Reino, desde o dia da Criação da Real Mesa Cençoria athé ao presente. Para servir no expediente da Caza da Revizão (1768-1814)"11, Colecção Real Mesa Censória, Livro n. 811, ANTT, in . ver autoria.

"Relação dos Quadros pertencentes á Herança da Imperatriz Rainha a Senhora D. Carlota Joaquina de Bourbon, hoje existentes no Real Palacio da Bemposta, onde hão-de ser vendidos em hasta publica, perante o Juiz do respectivo Inventario [...] e que forão descriptos e avaliados pelos Senhores António Manoel da Fonseca, Lente de Pintura Histórica da Academia das Bellas Artes de Lisboa, e Luiz Tirinnanzi, Pintor restaurador de quadros [...],AULETE, Francisco de Caldas, Lisboa, 1844.

\section{Manuscritos}

Academia Nacional das Belas Artes

1-A-SEC. 011, Acta ก. 0481

1-A-SEC. 011, Acta ก. 0482

1-A-SEC. 011 Acta n. 0483

\section{Arquivo Museu Imperial Rio de Janeiro}

I-POB-00.07.1807

07-I-POB-17.08.1805-JVI.P.d1-3

I-POB-21.07.1814 - CJ. P. rb

POB, D 1789, M.42

\section{Arquivos Nacionais da Torre do Tombo}

Casa das Rainhas, Maço 50

Casa das Rainhas, Livro 234

Casa das Rainhas, Maço 241

Casa Real, Cx. 3703

Casa Real, Cx. 6523

Casa Real, Cx. 7311

Casa Real, Arquivo Histórico do Ministério das Finanças, Livro 2979

Casa Real, Arquivo Histórico Ministério das Finanças, Cx. 7100

Casa Real, Arquivo Histórico do Ministério das Finanças, Cx. 7327

Casa Real, Plantas, Almoxarifado do Ramalhão, n. ${ }^{\text {os }} 314-315$

PT-TT-GAV-16-3-18 


\section{Biblioteca da Ajuda}

51-XIII-7, Catálogo da Livraria que foi de S. Mag.de A Senhora D. Carlota Joaquina de Bourbon $54-X-33$

Museu Nacional de Arte Antiga

Inventário da Pintura, Livro 4 e Livro de Aquisições 1850-1900. 


\section{Anexos}

Academia Nacional de Belas Artes de Lisboa

\section{A - SEC. 009}

Acta de 15 de Janeiro de 1844:

"O III.mo Director Geral falando nos quadros que estam inventariados e avaliados no Palácio da Bemposta para se venderem em hasta pública, disse que muito convinha que a Academia dirigisse uma representação ao Governo, pedindo que se comprassem por conta do Estado os que fossem originaes clássicos para se utilizarem na Academia, evitando-se que vão para fora do Reino, acrescentando que iria pessoalmente fallar a Sua Magestade a respeito deste objecto. Sendo geralmente adoptada a opinião do IIImo. Director, resolvêo a Conferencia que se fizesse a dita representação com toda a urgência."

\section{A - SEC. 011}

Acta N.ㅇ 481, de 30 de Março de 1959

Acta da conferência ordinária da Academia de Bellas Artes de Lisboa, de 30 de Março de 1859. "Depois do meio dia abriu a Conferencia o Ilmo. Director Geral, estando presentes os Sr.es Professores, faltando por doença o Sr.or José da Costa Sequeira.

Foi lida e aprovada a acta da conferencia antecedente.

Constou o expediente: D’huma Portaria do Conselho Superior d'Instrução Publica de 11 de Fevereiro, acompanhada do Edital [...]; d'um officio do Conde da Ponte de 17 do corrente, participando que na mesma data se ordenara ao Almoxarife do Real Palácio da Bemposta posesse à desposição d'esta Academia os quadros que se acham arrecadados no dito Palácio, pertencentes ao espolio da fallecida Imperatriz Rainha D. Carlota Joaquina de Bourbon, que foram arrematados por ordem do Governo para a mesma Academia. [...]

ANBA 1.A-SEC. 011 Acta 483, de 30 de Abril de 1859

Acta da conferência extraordinária de 30 d'Abril de 1859 destinada a reconhecer o estado em que se acham ou receberam os vinte e cinco quadros e dois baixos-relevos em mármore d'Italia, que pertenceram ao espolio da fallecida Imperatriz Raynha a Sr. a D. Carlota Joaquina de Bourbon que o Governo mandou arrematar para uso da Academia.

Quadro N.o 2 - Representando um cavaleiro antigo, meia figura, de Loilio. Descobriram-se no fundo deste quadro alguns retoques, e na parte superior da cabeça alguns pequenos restauros; assim como nas roupas da parte do escuro, faltas vesiveis de tinta original, também pessimamente restaurada. 
N.o 3 - Um Desembargador em meio corpo, ao natural - pelo cavalheiro Velasques - gasto em o todo e pessimamente restaurado, tanto na cabeça como nas roupas; faltando-lhe no fundo alguns bocados de tinta original que deixão ver o panno em que foi pintado.

N. 10 - Dous quadros pequenos, em panno, representando Paisagem, por João Baptista Bussunni, figura oval, retocados e um tanto estragados, faltando-lhes alguns bocados de tinta original.

N. 18 - Dous quadros em panno, representando um naufrágio d'um Navio e outro uma vista de mar de Cláudio José Vernet - ambos deteriorados em consequencia da muita sujidade e do mau verniz que lhes applicaram, tendo alguns restauros, tanto no fundo como nos objectos que compõem os quadros.

N. 35 - Uma Imperatriz Alemã por Bronzino - A cabeça e mãos alguns maus restauros, mas quasi que conservam a sua originalidade, tendo o fundo em geral muito arruinado e falta de tinta original em muitas partes.

N. 37 - Os dois irmãos - Escola Veneziana - na sua maior parte estam bem conservados, faltando-Ihes contudo alguma tinta original, e alguns pequeníssimos e maus restauros.

N. 63 - Um quadro representando a Paciência - por Pierino del Vago - Pela maior parte bem conservado, tendo nas roupas alguns péssimos restauros faltando-lhe no fundo alguma tinta original.

N.o 64 - Quadro representando Judith - por Guido Reni. Gasto em geral pelas más limpezas que the fizeram, pessimamente restaurado, principalmente na cabeça peito, braços e extremidades inferiores, e também em todo o fundo.

N. 67 - Quadro representando - Martyrio d'um Bispo - Escola de Rubens - Muito estragado e pessimamente restaurado.

N. 69 - Um dito pintado em panno, representando a - Pregação do Arcebispo João Ribeira Valência pregando aos Gentios - por Cades - Está em geral bem conservado, mas achasse um tanto dannificado pelo mão verniz que lhe applicaram; oferecendo também algumas faltas de tinta e alguns pequenos restauros.

N. 71 - Um quadro representando o Baptismo de Santo Ermenegildo notavelmente estragado e oferece alguns maus restauros, estando tam arido que em partes a tinta se solta do panno.

N. 77 - Apparição do descimento da Cruz a S. Francisco - Pela maior parte bem conservado, tendo contudo, alguns maus restauros, e no fundo algumas faltas de tinta original; sendo a cabeça de uma das árias pessimamente restauradas. 
N. 97 - Dois ditos em panno representando fruteiros por Pereda - Ambos muito áridos ou secos, e um d'elles, em partes, mal restaurado, e outro com um pequeno rasgão na parte inferior.

N. 117 - Um quadro pintado em taboa, representando a - Adoração dos Pastores - Escola de Raphael - Este quadro aliás bem conservado, mostra haver sido queimado na parte posterior, e é por isso que na parte anterior se vê a cabeça e mão de S. José pintadas todas de novo, tendo algumas fendas no fundo, e no horizonte um espaço muito mal restaurado.

N. 133 - Dois ditos em taboa, um representando a Adoração dos Reys Magos - e outro a Fuga para o Egipto, em dous momentos separados. - o primeiro tem o fundo muito mal restaurado, assim como a cabeça da S. a e do menino - o segundo geralmente deteriorado, em razão dos máos restauros que se lhe observam, estando mais estragado que o primeiro.

N. 137 - Um baixo relevo, reprentando Sta Maria Madalena em mármore - tem o dedo mínimo da mão direita restaurado e o dedo annelar da dita mão quebrado e mal unido com bitume.

N.. 150 - Um quadro pequeno em cobre representando - S. Francisco elevado ao Ceo pelos Anjos - original de Sequeira - cujo quadro parece ser antes S. Pedro d'Alcantara. Conservase em bom estado.

N. 164 - Um dito representando Jesus Christo com a Cruz às Costas - original de Luini está bem conservado, apresentando apenas uma pequena falta de tinta na parte inferior; teve uma péssima restauração, e no centro apparece a tinta gasta na túnica.

N. 175 - Um dito representando a Sacra Família e S. Francisco, de primeiro estylo de Raphael - Em geral está bem conservado, e apenas tem no fundo uma falta de tinta original.

N. 178 - Um dito em panno, representando - Jesus Christo com a Canna Verde no Pretório de Pilatos, apresentado ao Povo pelo mesmo - attribuido a Sebastião del Piombre Bastante arruinado e pessimamente restaurado. Falta-Ihe em grande parte a tinta original.

N.o 188 - Um alto relevo de mármore, original de Bernini, representando a - Adoração dos Anjos ao corpo morto de Jesus Christo depois do descimento da Cruz. - Bem conservado, excepto a falta de dedo mínimo da mão de Jesus Christo.

N. 190 - Dois quadros em panno com o mesmo numero, representando uma $A$ morte d'Abel - a tempera, e outro - Abrahão expelindo de cara a Agar. - 0 primeiro tem um rasgão e segundo algumas faltas de tinta.

Acabado o exame dos referidos quadros - accordou a Conferencia em que se continuassem a limpar do pó os ditos quadros e a dar-lhe uma demão de verniz, debaixo da direcção do Sr. Professor proprietário da Aula de Pintura Histórica.

Academia de Bellas Artes de Lisboa, 30 d'Abril de 1859. 
Francisco Vasques Martins, Secretario. Assinavam "Francisco de Assis Rodrigues, D. G.; João Pires da Fonte; António Manoel da Fonseca; Domingos José da Silva; Thomaz J. d’Anunciação; José da Costa Sequeira; Joaquim Pedro de Souza; Francisco Augusto Metrass".

Ofício dirigido a D. Manuel de Portugal e Castro. Vedor da Real Casa:

"Tendo sua Magestade a Rainha nomeado por Portaria da data de hoje, aos Professores das Academias das Bellas Artes de Lisboa e Porto, Joaquim Raphael, e Francisco António da Silva Oeirense e a Luiz Pereira de Menezes para passarem a examinar e classificar os quadros do espolio de Sua Magestade Imperial a Senhora Dona Carlota Joaquina [...] existentes para venda em leilão no Paço Real da Bemposta, que podessem servir, por sua preciosidade, d'estudo aos discípulos de Pintura e Esculptura da Academia de Lisboa, e devessem como taes ser collocados na Galeria Nacional ali já principiada a estabelecer: vou rogar a V.ㄹ Ex.ㅁ se digne dar as suas ordens para que aos nomeados se franquêe a entrada n'aquelle Paço e exame dos referidos quadros.

Deos guarde V.a Ex.a. Secretaria de Estado e Negócios do Reino, 2 de Maio de 1848. Duque de Saldanha. ANTT. Arquivo Histórico Minist. das Finanças. Caixa 7100. XX/Z/81 (12).

Ofício de D. Manuel de Portugal e Castro comunicando as instruções ao Almoxarife do Palácio da Bemposta:

Em virtude da comunicação que se me dirigio Sua Ex. a o Ministro e Secretario d’Estado dos Negócios do Reino, V.Mce facilitará a entrada n'esse Real Palácio aos Professores das Academias das Bellas Artes de Lisboa e Porto: Joaquim Rafael, Francisco António da Silva Oeirense e Luiz Pereira de Menezes, para eles examinarem os Quadros ahi existentes e annunciados para venda, prestando-lhes $\mathrm{V}$. M. todo o auxílio de que carecem os mesmos Professores para o exacto cumprimento da missão de que foram encarregados. Deus guarde a V. M. Vedoria da Casa Real, em 4 de Maio de 1848. D. Manuel de Portugal e Castro.

ANTT. AHMF, Cx. 7100, XX/2/81. 